ELISABETE MARTINS DA FONSECA

\title{
IMAGINÁRIO E FORMAÇÃO DE EDUCADORES: \\ A NARRATIVA DE SI
}

São Paulo

2016 


\section{IMAGINÁRIO E FORMAÇÃO DE EDUCADORES: A NARRATIVA DE SI}

Tese apresentada como requisito parcial para obtenção do titulo de Doutora em Educação no Programa de Pós-Graduação em Educação da Faculdade de Educação da Universidade de São Paulo sob a orientação do Prof. Dr. Marcos Ferreira-Santos.

São Paulo

2016 
Ficha Catalográfica: 


\section{Resumo:}

Nesta tese apresento a autobiografia como uma possibilidade de pesquisa em educação (Berkenbrock-Rosito, 2009; Gusdorf, 1991; Paula Carvalho, 1998; Ricoeur, 1991 e 1994; Ferreira-Santos, 1998, 2003 e 2005; Ferreira-Santos \& Almeida, 2012), admitindo que a narrativa autobiográfica oportunize o reconhecimento das marcas geradas pela e na pessoa, que ao narrar expressa o seu modo de ser, o seu imaginário.

Parte-se do princípio de que o imaginário é a força motriz dos processos de criação e, portanto, da formação dos educadores numa perspectiva da antropologia educacional.

Ao narrar seu percurso a educadora tem a oportunidade de reconhecer sua própria autoria, seu modo particular de criar novas experiências a partir das trocas geradas em seu cotidiano. Ao narrar a educadora também pode recriar-se.

A narrativa de si, como pesquisa autobiográfica, expressa pelo imaginário o sentido da obra a que cada pessoa dedica sua vida, revelando a diversidade dos seus itinerários de formação. Revela-se como uma oportunidade de reelaboração e de imersão no processo formativo, possibilitando o reconhecimento da obra do narrador ao ressignificar sua própria história.

Ao narrar meu percurso profissional pelo caminho da educação, reconheci as marcas de minha autoria impressas em cada uma das experiências profissionais nas quais atuei, como professora alfabetizadora, professora no ensino fundamental, médio e superior, e também como gestora e formadora na rede pública no ensino fundamental e na educação infantil.

Em cada uma destas experiências cotidianas reconheci a força do imaginário nos processos formativos. Força manifesta pelas produções autorais, quando deixamos de reproduzir o que fizeram conosco e passamos a criar nosso próprio modo de imprimir nossa marca no que fazemos.

A narrativa de si emerge como obra inacabada gerada no trajeto antropológico da pessoa em seu constante processo de constituição, na incessante troca de suas pulsões subjetivas e da objetividade de seu meio sócio-cultural.

Palavras-Chaves: Narrativa - Autobiografia - Formação de Professores - Imaginário Antropologia Educacional 


\section{Abstract:}

In this thesis I present the autobiography as a possibility of research in education (BerkenbrockRosito, 2009; Gusdorf, 1991; Paula Carvalho, 1998; Ricoeur, 1991 and 1994; Ferreira-Santos, 1998, 2003 and 2005; Ferreira-Santos and Almeida, 2012), assuming that the autobiographical narrative give brand recognition generated by and in person, when recounting that expresses his way of being, your imagination. It starts from the principle that the imagination is the driving force of the processes of creation and therefore the training of educators from the perspective of educational anthropology. In recounting his journey the teacher has the opportunity to recognize their own making, his particular way of creating new experiences from the exchanges generated in their daily lives. In recounting the educator can also recreate themselves. The narrative itself as autobiographical research expressed by the imaginary sense of the work that each person dedicates his life revealing the diversity of its training itineraries. It is revealed as an opportunity to restate and immersion in the training process, enabling the recognition of the narrator's work to reframe their own history. In recounting my career the way of education, I recognized the printed marks of my own in each of the professional experiences in which I worked as a literacy teacher, teacher in primary, secondary and higher education, as well as manager and trainer in public in primary and early childhood education. In each of these everyday experiences I recognized the imaginary strength in the formative processes. Force manifested by copyright productions, when we fail to reproduce what they did to us and we started to create our own way to print our brand in what we do. The narrative itself emerges as unfinished work generated in the anthropological path of the person in their constant process of constitution in the constant exchange of their subjective impulses and objectivity of their socio-cultural environment.

Key-words: Narrative - Autobiography - Teacher Training - Imaginary - Educational Anthropology 


\section{Dedicatória}

Dedico este trabalho à minha mãe Maria do Carmo que, em vida, inspirou meus estudos, meu trabalho e minha atitude diante da vida.

Dedico esta empreitada de decidir pela escrita da tese a todos os que colaboraram em minha jornada. Às amigas parteiras tecelãs, professoras, amigas, minha irmã e minha terapeuta. Ao mestre lunar que me orienta Marcos Ferreira-Santos; e ao meu pai, José, pelo exemplo de vida, trabalho e simplicidade, e que do alto da vitalidade de seus oitenta e dois anos, ligou-me incansavelmente ao longo destes dias de escrita intensiva, período que transformei em casulo, um novo útero, para nele poder parar para escrever. Agradeço seu amor paternal.

Agradeço a professora e amiga Maria do Rosário Silveira Porto pela confiança e generosidade ao me estimular avançar pelos caminhos da pesquisa, desde a iniciação científica, durante o mestrado e em momentos muito especiais de minha formação pessoal.

A minha irmã Elma, meu cunhado Marco Antonio e meus sobrinhos Marco Aurélio e Caio Vinicius pela convivência sempre fraterna.

A minha amiga e terapeuta Stephanie pelo carinho e atenção em acompanhar meu desenvolvimento.

Às minhas amigas sempre queridas Sandra Lacerda, Roseli Helena e Cecília Regina pelo incentivo constante.

Aos colegas educadores, crianças e jovens da rede municipal de ensino de São Paulo.

Aos pedagogos que escolheram a educação por amor.

Aos meus queridos alunos que deram e dão sentido ao meu trabalho. 
É com uma alegria tão profunda. É uma tal aleluia. Aleluia, grito eu, aleluia que se funde com o mais escuro uivo humano da dor de separação, mas é grito de felicidade diabólica. Porque ninguém me prende mais. Continuo com capacidade de raciocínio - já estudei matemática que é a loucura do raciocínio - quero me alimentar diretamente da placenta. Tenho um pouco de medo: medo ainda de me entregar pois o próximo instante é o desconhecido.

o próximo instante é feito por mim?

Fazemo-lo juntos com a respiração. E com uma desenvoltura de toureiro na arena.

Eu te digo: estou tentando captar a quarta dimensão do instante-já que de tão fugidio não é mais porque agora tornou-se um novo instante-já que também não é mais. Cada coisa tem um instante em que ela é. Quero apossar-me do é da coisa. Esses instantes que decorrem no ar que respiro: em fogos de artifício eles espocam mudos no espaço.

Quero possuir os átomos do tempo. E quero capturar o presente que pela sua própria natureza me é interdito: o presente me foge, a atualidade me escapa, a atualidade sou eu sempre no já. Só no ato do amor - pela límpida abstração de estrela do que se sente - capta-se a incógnita do instante que é duramente cristalina e vibrante no ar e a vida é esse instante incontável, maior que o acontecimento em si: no amor o instante de impessoal jóia refulge no ar, glória estranha de corpo, matéria sensibilizada pelo arrepio dos instantes - e o que se sente é ao mesmo tempo que imaterial tão objetivo que acontece como fora do corpo, faiscante no alto, alegria, alegria é matéria de tempo e é por excelência o instante. E no instante está o é dele mesmo. Quero captar o meu é. E canto aleluia para o ar assim como faz o pássaro. E meu canto é de ninguém. Mas não há paixão sofrida em dor e amor a que não se siga uma aleluia. Meu tema é o instante? meu tema de vida. Procuro estar a par dele, divido-me milhares de vezes em tantas vezes quanto os instantes que decorrem, fragmentária que sou e precários os momentos - só me comprometo com vida que nasça com o tempo e com ele cresça: só no tempo há espaço para mim.

Escrevo-te toda inteira e sinto um sabor em ser e o sabor a ti é abstrato como o instante. É também com o corpo todo que pinto os meus quadros e na tela fixo o incorpóreo, eu corpo-a-corpo comigo mesma. Não se compreende música: ouve-se. Ouve-me então com teu corpo inteiro. Quando vieres a me ler perguntarás por que não me restrinjo à pintura e às minhas exposições, já que escrevo tosco e sem ordem. É que agora sinto necessidade de palavras - e é novo para mim o que escrevo porque minha verdadeira palavra foi até agora intocada.

A palavra é a minha quarta dimensão.

(Água Viva - Clarice Lispector) 


\section{Índice}

Resumo.................................................................. p. 04

Dedicatória................................................................. p. p 06

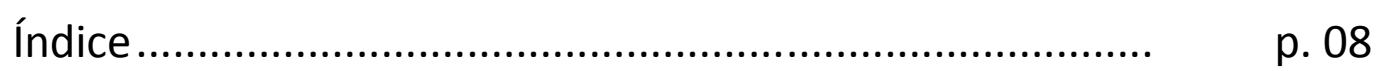

1. Uma Busca............................................................. p. 09

2. Instante poético e pesquisa autobiográfica..................... p. 27

3. Carne de Língua e Maa Ngala........................................... p. 31

4. Do Reino Devastado e de Sua Regeneração...................... p. 36

5. A imagem labiríntica: vertigem, voragem e vórtice.......... p. 52

6. A fome da alma............................................................ p. 63

7. O Vôo da Fênix: A Experiência como Coordenadora

Pedagógica e como Formadora de Educadores................. p. 102

8. A sede do corpo........................................................... p. p. 121

9. O Vôo da Borboleta: Ariadne, Ártemis e o Encontro de

Lumina profundis.......................................................... p. p. 133

10. Prósopon: Em Busca da Experiência Numinosa do

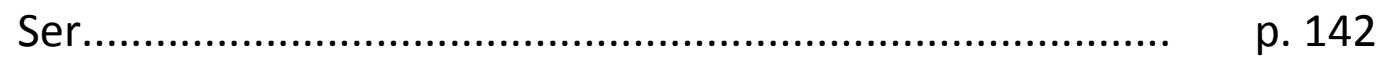

11. Empoderamento da mulher: considerações finais p. 156

$\begin{array}{ll}\text { Bibliografia } & \text { p. } 177\end{array}$ 


\section{Uma Busca}

"A trajetória não é simplesmente um modo de ir.

A trajetória somos nós mesmos."

Clarice Lispector

Conferia se tinha colocado toda a bagagem: roupas, sapatos, cosméticos, livros e CD's preferidos e os meus guias cartográficos.

Minha pouca experiência em aventuras geográficas, fazia daquele momento um estalar mágico de dedos que me apresentava à grandiosidade do instante: enfrentar a estrada sozinha.

Havia me divorciado naquela semana entre as datas mais comemoradas no Ocidente: o Natal e o Reveillon. Duas datas marcantes: na primeira costumamos comemorá-la em família e na segunda ampliamos nossas escolhas.

Geralmente no Natal identificamos símbolos da Ceia Sagrada, reafirmando a mística cristã, compartilhando com nossa pertença a importância de estarmos unidos. Buscamos a presença do Deus Pai, em sua Santa Trindade: um Deus Pai Generoso, Protetor, Afável, Grandioso, Poderoso e Eterno, materializado no Cordeiro.

Já durante o Reveillon é muito comum ampliarmos o grupo de pessoas com quem fazemos a virada de ano, ampliando para parentes mais distantes, amigos, lugares e pessoas novas em nossas vidas.

Algumas vezes, buscamos numa tradição de país tropical, lançar ao mar nossa gratidão e súplica. Agradecendo o ano velho e o ano novo. Devotando nosso reconhecimento de que somos filhos da natureza e do sagrado.

Ao encontro no novo ano desapegamo-nos das velhas certezas, de nossas armaduras e das peles já ressecadas. Há um forte desejo de renascimento. Buscamos o grande mar como se estivéssemos saindo ao encontro do útero de Gaia. Buscamos a Grande Mãe. A Sagrada que reconhece nossa condição humana e errante. Lançamo-nos rumo ao desconhecido, à Terra do Maná da Prosperidade, ao Eldorado dos Sonhos ainda não realizados, mas desejados com toda a força e a verdade de nossas entranhas.

Estamos todos renascendo geralmente vestidos de cores que expressam nossos desejos. Rumo a um novo ano, revestimos nosso sacrifício de esperança, de uma possível renovação, ainda que a realidade objetiva nem sempre coincida com a pulsão de nossas expectativas. 
A pulsão de vida abraça a pulsão de morte num encontro cíclico que reafirma a espiral de nascermos novamente junto à Divindade, mas reconhecendo em nossa finitude, nossa condição humana num ano que se inicia e que remonta os primórdios de toda criação.

Ofertamos ao grande Mar nossas homenagens ao grande útero. Ainda que não depositemos nenhum objeto em suas águas, a ele entregamos simbolicamente, o que há de mais precioso: nossa presença, nosso Prósopon. Ao contemplá-lo podemos olhar para dentro, viajar em nosso íntimo, movidos pela brisa musical da maresia que nos acalanta.

Buscamos o abraço da Grande Deusa Mãe que completa a perfeição de um casamento sagrado, do masculino e o do feminino, do início e do fim, do pai e do filho, da mãe e da filha, do ir e vir da maré, num movimento que remonta a cópula fértil e sagrada da criação.

Olhamos um horizonte, contemplamos a Lua, o Sol, o Crepúsculo; e a eles nos unimos no firmamento de nossas aspirações quando no começo era apenas a escuridão e dela surgiu a luz. Encontramos no Caos da correria do último dia do ano, a energia geradora para a instauração de uma nova ordem, na cosmogonia de um novo ano. Abrimos nossos braços ao mistério e a ele nos entregamos com humildade pedindo saúde, paz, amor, união e prosperidade.

Ofertamos à Grande Mãe do Sagrado Feminino que habita os oceanos, nossos agradecimentos e nossas súplicas de misericórdia aos pedidos que apontam para um novo recomeço, a busca de uma vida nova, na cíclica e sagrada rítmica do devir.

Era assim que iniciava em 2010, um novo ano. Lançava-me ao desafio de sozinha, pela primeira vez, dirigir meu carro e contemplar as curvas da sinuosa estrada, buscando as promessas de felicidade que os mirantes permitiam-me contemplar. Buscava a mim mesma, ainda que não o soubesse.

A mãe natureza, as visões da serra, a imagem incrivelmente revigorante do mar inspiravam-me a descobrir na pulsão de minhas entranhas a força necessária para continuar viva. Ainda que a sombra do fracasso batesse na porta do meu coração partido, tinha que buscar novas experiências, vislumbrar novos horizontes, voltar para o lugar onde estava antes de iniciar meu relacionamento com meu ex-marido. Voltar aos começos, para finalmente partir, para uma vida nova.

Buscava enfrentar o medo da solidão. Estava ainda sem saber tantas coisas do que teria que superar em minha vida prática, desde minha reorganização financeira até os pequenos detalhes do cotidiano. Mas a dor de não ser mais a rainha do lar, aquela que aguarda a proteção de seu rei e a promessa de possíveis herdeiros perseguia-me como sombra. Queria superar com 
dignidade e amor próprio sem olhar para trás. Mas para seguir em frente precisava buscar nas águas da ancestralidade, os nutrientes para a minha alma sedenta.

Minha alma tinha fome e sede de esperança. Sabia que era mais que a guardiã do lar e de futuros herdeiros, tinha investido muito em minha profissão, e de fato, meu trabalho sempre foi um catalisador de sentido em minha vida.

Contudo, precisava descobrir quem era para além da pedagoga e da mulher de coração partido. Eis a jornada infinita. Mais um novo giro de espiral para me fortalecer e impulsionar para o que tinha pela frente. Transmutar. Transformar um fim em novo começo. Descobrir as mulheres que me habitam.

Aceitar o convite daquela viagem era algo irrecusável. Mas era bem mais que suprir minha carência materna e a saudade de tias queridas. Somente com o tempo pude perceber isso. Assumir, sozinha, novos riscos me oportunizou um reencontro comigo mesma.

Afinal atendia a um convite de tias irmãs de minha mãe já falecida. O destino era Juqueí, litoral norte de São Paulo, local onde oito anos antes comemorei minha lua de mel. Oportunidade de rever aquele mar, para buscar o poder lunar.

A acolhida das tias ligou-me à minha ancestralidade materna.

Para além do abraço das tias, abraçava minha condição de órfã que estava perdendo a inocência e recebendo as forças invisíveis das mulheres ancestrais de minha família. Minha mãe de origem cabocla natural do Sergipe, herdou de minha avó, traços de origem indígena. Mulheres de perfil provedor, carregadas de fé e das marcas de uma condição muito humilde. Eram trabalhadoras na casa, na roça e na cidade. Era um abraço que me dizia:

"- Seja bem-vinda, filha querida, ao grupo das mulheres persistentes. Desenvolva sua garra. Não perca sua alegria. Reconheça seus limites. Chore se assim for preciso, mas em seguida levante-se e se olhe no espelho. Quando lá você estiver nos verá em você. Sorria, pois vivemos através de você e você do nosso sopro, além do tempo."

Ao escrever esta narrativa, reconheci após mais de cinco anos, que naquela viagem tão simples e especial, recebi o abraço da mãe oceânica.

Era ela quem arquetipicamente materializava-se no convite de minhas tias que expressavam a súplica de minha mãe Maria do Carmo a evocar ao Eco do Tempo, onde todas as vozes se encontram na profundidade do Amor Verdadeiro. A súplica de uma mãe amada à Mãe Abençoada, clamando por sua filha Elisabete. 
A súplica que rompe o tempo no mover mágico do vento e que transforma o lamento em uma brisa fria, maresia rítmica a beira mar.

Lá abracei minhas tias e primos enquanto saudávamos o início de 2010 . Ao amanhecer de um novo ano renascia a menina mulher fortalecida pela perda e renovada pelo encontro, surgia pelas águas ancestrais, das espumas de Poseidon brumadas na fertilidade de Afrodite. No movimento em cadência entre as ondas do mar e as pulsões que dentro de mim reverberavam. Quando cheguei a Juqueí sentia-me vitoriosa por ter enfrentado sozinha oito horas de viagem, superando trânsito, queda de barreiras na serra, excesso de carros, estrada sinuosa e minha inexperiência como viajante e motorista. Lembro que cheguei febril ao meu destino, mas ao reconhecer que havia chegado ao endereço certo, alegrei-me.

Ao abraçar minhas tias e primos fui tomada de uma emoção inesquecível, como se abraçasse à minha ancestralidade. Minha origem de pais nordestinos, de avós filhas do Imaculado Coração Sagrado de Maria.

Ao escrever esta narrativa após seis anos voltei a sentir a mesma emoção, porém com um olhar mais atento sobre os significados mais velados daquela experiência e o quanto aquela ruptura traria consequências para todas as dimensões de minha vida, incluindo minha experiência profissional.

Em 2010, saía da inocência e da orfandade numa busca incessante pela sobrevivência em todos os sentidos. Buscava pertencimento, ancestralidade, acolhimento e força. Ao voltar daquela viagem fui a cada dia me dando conta dos inúmeros desafios que me aguardavam nas curvas da estrada sem fim.

Um novo estado civil. Um novo modo de me vestir, outra cor de cabelo, outras formas de me apresentar para a vida. Dirigir o carro, dirigir a vida soavam como possibilidades, mas logo percebi a dialógica relação que desenvolvemos com a realidade circundante. $O$ fato, é que também somos dirigidos. A vida muda em uma volta, num breve instante. Morremos e renascemos. Entropia e neguentropia constantes.

A experiência profissional no setor do DOT - Diretoria de Orientação Técnica, entre os anos e 2010 a 2013, entre pessoas que admirava ofereceram-me temporariamente a pertença almejada. Mas todas as mudanças seguintes desafiaram-me a encontrar meu maior refúgio em minha fé.

Renasci várias vezes graças a isto. A fé de que cada episódio de morte vem acompanhado de um lampejo de vida, de recomeço, de capítulo novo. 
Renascia pela força do meu trabalho. Renascia pela fé de que teria muitos outros capítulos a escrever na narrativa, de perceber-me inteira naquilo que me faltava, como ser autêntico em sua luz e sua sombra.

Era assim que o neóteno-neguentropo ${ }^{1}$ ressurgia das cinzas de um fim de casamento, para novas experiências.

Disso, emergiam sinais lunares da arqueira que passou a não mais temer a noite, assumindo sua condição de ser errante.

A rítmica da saia rodada da cigana descrita no texto materializa a pulsão de uma mulher que não teme perder-se para encontrar-se.

Assim foram inúmeros, os momentos em que me perdi, já não me reconhecendo na menina inocente, na órfã sofredora, nem mesmo na generosa mártir, que nega a si mesma para fortalecer os outros, como me percebi no início de minha carreira profissional.

Acredito que as perdas tenham despertado minha necessidade de explorar outros modos de ser. Já não me importando tanto com a opinião alheia.

Passei a estar mais tempo fora de casa, numa rotina de trabalho muito intensa, sendo provedora, aprendendo a lidar de uma maneira integral com todas as dimensões práticas e simbólicas do meu dia-a-dia.

Talvez a Grande Deusa transmutava-se, silenciosa em minhas entranhas, na necessidade de ressurgir para além da guerreira, arqueira e exploradora.

Ser a tecelã na escola, como coordenadora pedagógica atendia parcialmente meu desejo de criação pela poética das vivências entre adultos e crianças.

Após quase um semestre sem escrever sobre minhas experiências como formadora, objeto de estudo central de minha tese, sentia-me desanimada reconhecendo as limitações das Políticas Públicas ao desempenhar meu papel de coordenadora pedagógica e também como ser humano. Estava me sentindo solitária ao desempenhar minhas atribuições. Sentia um esvaziamento; como se por muito tempo estivesse liderando grupos, sendo coordenadora na escola pública e professora numa universidade particular, e assumisse a minha fragilidade como pessoa.

\footnotetext{
1 "A neotenia afirma a condição de inacabamento humano, o longo processo biológico de desenvolvimento que torna o homem aberto à transformação e, consequentemente, ao aprendizado. Aprendemos ao longo de toda a vida. Logo, as pressões pedagógicas dos meios sociais, dos bens e comportamentos culturais estão sempre presentes no processo de formação, atualizando constantemente o imaginário individual e dos grupos." (FerreiraSantos \& Almeida, 2012, p.78)
} 
Minhas utopias embora presentes, não eram compartilhadas nos diversos segmentos da escola e também nas posturas de alguns alunos, que nem sempre demonstravam identificação com o perfil de educadores, e isso me entristecia. Mas, já sabemos que as utopias, servem para isso. Não as alcançamos, mas nos desafiam a sair do conformismo, experimentando novas formas de ser.

Mas, precisava vivenciar experiências motivadoras, extrair mais néctar da vida. Tornar a jornada mais prazerosa e criativa e apesar dos inúmeros projetos que estávamos realizando na escola e dos bons resultados encontrados no trabalho na faculdade, estava me sentindo esgotada. Minha produtividade não era a mesma. Era como se eu precisasse desenvolver novas dimensões do meu ser. Viver mais ludicamente. Estava tensa, persecutória e solitária. Não me sentia capaz de agregar como coordenadora pedagógica visões tão antagônicas ao acompanhar práticas profissionais tão contraditórias. Meu jogo de cintura no cotidiano, ao articular práticas e atendimentos, convivendo com pessoas tão diferentes, exigia-me uma dose maior de flexibilidade. A cultura escolar como um todo é bastante desafiadora para o trabalho da gestão, especialmente numa instituição pública.

Precisava ampliar minhas experiências, oxigenar meu olhar, reorganizar minha vida como um todo. Sentia que no meu íntimo necessitava modificar algumas coisas no plano profissional e pessoal. Ter mais tempo para investir na minha qualidade de vida num sentido mais amplo.

Porém, minha rotina não estava correspondendo a este anseio. Talvez por isso, às vezes me sentisse tão cansada, desmotivada, com recorrentes crises alérgicas e baixa imunidade.

Este desejo de mudança estava trazendo gradualmente outras formas de organizar minhas ações. Nas duas últimas reuniões pedagógicas que planejei, reconheci em minhas escolhas para a organização das pautas, elementos muito significativos em minha jornada. Busquei elementos, que estivessem ancorados, em minha própria história.

$\mathrm{Na}$ véspera da penúltima reunião, lembro ter percorrido as estantes de meus livros pessoais em casa, para escolher uma leitura a ser compartilhada no início da reunião. Estas escolhas foram fecundadas pelo Imaginário: no diálogo entre imagens, mitos e arquétipos e a realidade circundante, caracterizando meu trajeto antropológico.

Escolhi um conto africano do livro "As Narrativas Preferidas de um Contador de Histórias" de Ilan Brenman² chamado: Carne de Língua.

O conto relata a importância das histórias para manter a saúde do corpo e da alma de mulheres, homens, crianças, jovens, velhos e até mesmo para os reis.

\footnotetext{
${ }^{2}$ Brenman, 2007, p.11
} 
A escolha desta história reanimou minha própria voz, explicitando aspectos interditos, desejos velados e transformações em processo, como se estivessem germinando numa panela coberta submetida a altas temperaturas, feito milho sendo aquecido para "pipocar". Um processo alquímico começava a ganhar uma nova forma, mas a matéria ainda se encontrava adormecida. Ainda não havia sido acordada pelo sopro visceral. Porém os elementos já estavam se reorganizando: ar, fogo, terra e água.

Usando a matriz dos quatro elementos, Bachelard veio a descobrir que (...) imagens são 'matéria dinâmica' derivada da nossa participação ativa no mundo e constituem a carne espiritual, a eflorescência do que é o mais profundamente sentido e expresso pelo homem em sua própria interioridade. (...) Bachelard veio, assim fazer sua principal descoberta: a imaginação é o produto de forças imaginantes, a saber, o denominador comum de toda construção imaginária é verbal (dinâmica), em vez de substantiva (estática) ou mesmo qualificante (descritiva). ${ }^{3}$

Há algo anterior ao conhecimento que este não pode compreender. O diverso sensorial, em sua originalidade, não se apresenta como um momento cognitivo, como uma notícia ou informação sobre algo - em que, sem dúvida depois se transforma - mas tem mais afinidade e analogia com os processos volitivos, com o desejo, com o apetite e a aspiração. Para compreender a relação entre o momento sensorial e a capacidade volitiva podemos nos reportar a Benedetto Croce $^{4}$ que nos diz em sua Filosofia Prática ser o homem um microcosmo de volições no qual se reflete todos os cosmos e contra o qual ele reage, 'querendo' em todas as direções. Estas palavras poderiam fazer surgir a suspeita de que esse cosmos "querido" (e "querido" em todas as direções) nada mais seria que o relevo exterior, o negativo, a projeção exterior desse âmbito interno do querer, que é nosso eu passional.

[...] Nossos atos de atenção são episódios sensacionais, extraídos dessa continuidade chamada duração. A trama contínua, onde nosso espírito borda desenhos descontínuos de atos, é apenas a construção laboriosa e fictícia do nosso espírito. ${ }^{5}$

Acrescentemos a observação e definição de Bachelard nos seguintes termos:

(...) Posto que a atenção tem a necessidade e o poder de refazer-se, ela permanece inteira cada vez que o faz. A atenção, também é uma série de começos, estando constituída

\footnotetext{
${ }^{3}$ Gilbert Durand apud Lima, 1976, p.183.

${ }^{4}$ Croce apud Lima, 1976, p.166

${ }^{5}$ Roupnel apud Lima, 1976, p. 166
} 
desses, ou por esses renascimentos do espírito que voltam à consciência quando o tempo cria o instante. ${ }^{6}$

Ao narrar meu processo formativo algumas memórias destacaram-se em relação a outras. No instante em que realizo a escrita, é ela que me recria. Ao escrever sou movida pelas imagens que me despertam e que ressignificam a jornada. Afinal, eu escolhi o conto ou fui escolhida por ele?

Além disto, assinalemos que, caso dirijamos essa atenção para o espetáculo que nos rodeia (caso no lugar da atenção para o pensamento íntimo tomemos a atenção para a vida), veremos de imediato que ela surge sempre de uma coincidência. A coincidência é o mínimo de novidade necessária para fixar o nosso espírito. Nos cabe lembrar as implicações do exposto acima, com a importância, tanto no processo amoroso como no processo artístico, do que costumamos denominar de 'me despertou', de 'me chamou a atenção', ou seja, daquela imagem ou daquela figura 'que passa' e nos fascina e/ou rapta, num instante, bem como, com as 'correspondances' dos poetas e o sincronismo na psicologia profunda.

Considere-se que a memória faz parte desse querer. É sabido que a emoção mexe com a alma. Está em sua etimologia "aquilo que move". O emocionar-se dá as grandes linhas sensíveis de uma pessoa, movimentando-a. O movimento e o ritmo que desdobra as linhas do corpo, a rigor, move o desejo. A função do amador é restabelecer a feminilidade convexa da amada. As verdades poéticas, como as verdades amorosas, requerem uma linguagem própria para serem expressas. Por exemplo: a verdade poética requer uma linguagem poética e amorosa quer uma linguagem amorosa. Assim, o verbo que se faz carne, se faz corpo. ${ }^{7}$

Ao mover-me no espetáculo da vida, as marcas que deixei por onde passei, também ficaram impressas em minha carne. Aprendi com outras pessoas a ser alguém diferente nas novas edições do cotidiano. Do mesmo modo contribuí para a aprendizagem daqueles que conviveram comigo, numa troca incessante.

A narrativa autobiográfica tal como na modelagem da argila, vai se construindo numa linguagem própria, não seguindo nenhum roteiro prévio, nem linearidade ou cronologia. São as imagens que brotam pelas emoções geradas por cada experiência. Os eventos que foram mais significativos ficaram impressos em meu modo de ser. Disto, emerge o significado da formação como ato contínuo e compartilhado. Como pessoa inacabada que sou, surjo em cada novo parágrafo, desvelando-me num jogo de espelhos, pelas modelagens do mito. Olhando-me no

\footnotetext{
${ }^{6}$ Bachelard apud Lima, 1976, p.166

${ }^{7}$ Lima, 1976, p. 167
} 
espelho, sou capaz de ver as marcas do tempo deixadas em meu corpo, também expressas na narrativa de si, como num diálogo, ao reler-me em cada nova linha.

Desde que era pré-adolescente sempre tive o hábito de escrever diários. Alguns versos que com o passar do tempo foram ganhando densidade, em seus sentimentos, projeções e imagens. Quantas vezes nesses diários eu questionava sobre meus temores e conflitos. Lendo o que escrevia, com o distanciamento do tempo, podia dialogar com o texto escrito, ora me reconhecendo nele, em outras, surpreendendo-me ser alguém que ainda não conhecia.

Escrever meus sentimentos era uma forma de expressar minha identidade em formação. Possibilitava-me ouvir minhas vozes interiores. E dizendo com Clarice Lispector, uma das autoras que já me acompanhava na adolescência: "escrevo-te toda inteira e sinto um sabor em ser e o sabor a ti é abstrato como o instante. É também com o corpo todo que pinto os meus quadros e na tela fixo o incorpóreo, eu corpo-a-corpo comigo mesma. Não se compreende música: ouve-se. Ouve-me então com teu corpo inteiro".

Nos diários escrevia de um modo próprio, sem a necessidade de seguir qualquer regra ou norma escolarizada. Podia brincar de ser poeta e me reconhecer como pessoa por inteiro, isto é, em sua sombra e em sua luz. Nas palavras que me orgulhava falar, e naquelas que ficavam guardadas nas linhas de meu diário confidente, e que abriam uma nova dimensão para conhecer meus sentimentos, desejos e temores.

Naquela época não tinha a dimensão do quanto escrever sobre a vida, seria uma ação tão presente em meus futuros estudos na universidade, na minha atuação como profissional, e especialmente como ferramenta de empoderamento. Um texto que buscava na poesia imagens que me constituíam, e delas erguia-se um espelho, empoderando-me de confiança para trilhar pela vida, enfrentando os desafios da juventude.

Este hábito de escrever como "autoterapia" ou autoconhecimento" acompanhou-me pela adolescência, e foi gradualmente, diminuindo ao aproximar-me da vida adulta, na qual passei a desempenhar novos papéis e múltiplas responsabilidades.

Foi na graduação de Pedagogia na Faculdade de Educação da USP, já no primeiro ano, que tive a oportunidade de vivenciar esta prática de realizar minha autobiografia. Na disciplina de Didática com a professora Helena Coharik Chamlian, numa perspectiva que buscava investigar a formação e o desenvolvimento profissional de professores, abordando temas como: didática, relação pedagógica, formação continuada a partir de relatos autobiográficos e das histórias de vida. Foi nesta experiência que conheci as contribuições de Antônio Nóvoa. 
Escrever minha autobiografia, em meu primeiro ano de graduação foi um exercício desafiador, mas que ampliou meu olhar sobre meu próprio processo formativo. Nessa perspectiva, as recordações escolares de momentos significativos se apresentaram como um recurso valioso para reflexão num curso de formação de professores, pois retratavam situações que poderiam servir como parâmetro para análise e compreensão da prática pedagógica e das relações vivenciadas no cotidiano escolar.

Ainda naquele ano, em 1994, tive a oportunidade de conhecer a professora Maria do Rosário Silveira Porto e a partir do seu convite participar de um projeto integrado de pesquisa como bolsista de Iniciação Científica: Imaginário e Ideário Pedagógico: um Estudo Mitocrítico e Mitanalítico do Projeto de Formação do Pedagogo na FEUSP participando da investigação da presença do imaginário dos alunos da FEUSP em suas produções orais e escritas, citada a seguir:

Nesse sentido, foram levantados, a partir dos textos produzidos pelos alunos, os mitos pessoais e coletivos do grupo investigado, observando seu contexto situacional, valendo-nos, para tanto, até mesmo de conversas de corredor, as quais, por seu caráter informal, revelaram-nos as impressões espontâneas dos alunos. Isto porque, é na linguagem dos palcos e dos bastidores, que são enunciados os ideais acerca da educação e que refletem os elementos que pululam no imaginário, nos meandros do dito e do não dito.

Admitindo o exposto, o texto só pode ser compreendido, quando interpretado na dimensão de seu contexto, na complexa teia que liga as relações humanas por meio da cultura, que ao tecer o homem é transformada por ele, dinamicamente.

(...) Assim, em conformidade com a fundamentação metodológica da Teoria Geral do Imaginário de Gilbert Durand, destaca-se a importância de uma cultura latente (mitologia) - que é mais intensa enquanto mais oculta - que se cristaliza numa cultura patente (ideologia).

É preciso, entretanto, considerar-se a recursividade entre esses pólos - o técnico e o fantasmático das organizações sociais, destacando-se a articulação entre a cultura patente, que se caracteriza por um sistema de metas e meios racionalmente dispostos, e a cultura latente, que se constitui no nível afetivo (inconsciente), ancorando-se no plasma existencial, que alimenta a sobrevivência e a transformação dos grupos. ${ }^{8}$

Foi ao participar desta experiência como bolsista que me aproximei da linha teórica "Cultura, Organização e Educação" e conheci o referencial teórico que me revelou a Antropologia do Imaginário de Gilbert Durand, a Culturanálise de Grupos proposta por Paula Carvalho, a

\footnotetext{
${ }^{8}$ Paula Carvalho, 1998, p.101.
} 
Antropologia da Complexidade de Edgar Morin e a Sócio-Antropologia do Cotidiano de Michel Maffesoli.

Bebendo nas águas regeneradoras deste referencial teórico reconheci a profundidade da narrativa e dos relatos autobiográficos, a partir da emergência do Imaginário como fonte de todas as produções humanas, revelado nas imagens construídas pelas metáforas do texto e pelos fatos narrados como um caminho para a expressão dos mitos plasmados neste discurso. Como bolsista auxiliei a professora Maria do Rosário Silveira Porto na coleta e análise das produções dos alunos da FEUSP, entre elas suas histórias de vida, ou como diria Paula Carvalho suas "estórias de vida".

Vivenciando os estudos passei a me reconhecer como sujeito e objeto de pesquisa, dada a minha própria produção autobiográfica ser analisada como aluna do curso de Pedagogia, ao iniciar meu percurso de pesquisadora como bolsista.

Esta experiência despertou o desejo de realizar o mestrado: Trilhando o Labirinto: Uma Incursão Antropológica à Latência de uma Escola Municipal. Dissertação de mestrado defendida em 2002. Nesta pesquisa investiguei o imaginário do grupo docente do qual fazia parte.

A presente tese Imaginário e Formação de Educadores: a Narrativa de si, surgiu deste percurso e do olhar sensível do professor Marcos Ferreira-Santos que ao me acolher no doutorado em 2012, incentivou-me a reconhecer o fio de minhas experiências investigativas: a autobiografia, minha "estória de vida", que aqui se materializa como: Narrativa de Si.

Vale explicitar que compartilho da tese de Paula Carvalho ao afirmar:

E nossa tese vai no sentido de considerar as estórias de vida como "matéria imaginária" e "matéria imaginal", isto é, como portadoras, enquanto relatos que são, da dinâmica da função simbólica ("função transcendente" em Jung); portanto, de modo latente e profundo, relatos míticos: portadoras das figurações mítico-imaginais e das figuras míticas e imaginais num percurso que é, de modo latente e profundo, um trajeto iniciático.

(...) Ricoeur afirma que a ficção é o caminho privilegiado da re-descrição da realidade e que a linguagem poética é a linguagem que opera por excelência aquilo que Aristóteles, refletindo sobre a tragédia, chamava de mimesis da realidade; com efeito, a tragédia não imita a realidade senão porque a recria através de um mythos, de uma fábula, assim atingindo a essência mais profunda dela. Por isso a hermenêutica deve incorporar esse distanciamento e o poder mitopoético veiculado pelo mundo do texto. 0 mundo do texto diz Ricoeur, é uma proposição de mundo, de um mundo tal como eu possa habitar para aí projetar um de meus possíveis mais íntimos. A tarefa da interpretação consiste em desvendar essa proposição de mundo, mas 
precisamente naquilo que ela me concerne, que me diz ou pode me dizer a respeito. Aliás, esse é o sentido de "fenômeno", da voz média "apophainesthai", como lembra Corbin. A quarta dimensão da noção de texto, diz Ricoeur, consiste em mostrar que o texto é a mediação pela qual nos compreendemos a nós mesmos. Compreender é compreender-se diante do texto. Não impor mais ao texto uma específica capacidade finita de compreender, mas expor-se ao texto e dele receber um si-mesmo mais vasto, que seria a proposição da existência respondendo do modo mais apropriado à proposição do mundo. A compreensão será então o contrário de uma constituição cuja chave estaria no sujeito. Seria mais justo dizer que o si-mesmo é constituído pela "coisa" do texto. ${ }^{9}$

Nesta tese apresento a autobiografia como uma possibilidade de pesquisa em educação, admitindo que a narrativa autobiográfica oportuniza o reconhecimento das marcas geradas pela e na pessoa, que ao narrar expressa o seu modo de ser, o seu imaginário ao compreenderse no trajeto, abrindo-se à "coisa" do texto.

Parte-se do princípio de que o imaginário é a força motriz dos processos de criação, e portanto, da formação dos educadores.

Ao narrar seu percurso o educador tem a oportunidade de reconhecer sua própria autoria, seu modo particular de criar novas experiências a partir das trocas geradas em seu cotidiano. Ao narrar o educador também pode recriar-se.

A narrativa de si, como pesquisa autobiográfica, expressa pelo imaginário o sentido da obra a que cada pessoa dedica sua vida, revelando a diversidade dos seus itinerários de formação. Revela-se como uma oportunidade de reelaboração e de imersão no processo formativo, possibilitando o reconhecimento da obra do narrador ao ressignificar sua própria história.

Nesta tese, ao narrar meu percurso profissional pelo caminho da educação, reconheci as marcas de minha autoria impressas em cada uma das experiências profissionais nas quais atuei, como professora alfabetizadora, professora no ensino fundamental, médio e superior, e também como gestora e formadora na rede pública no ensino fundamental e na educação infantil.

Em cada uma destas experiências cotidianas reconheci a força do imaginário nos processos formativos. Força manifesta pelas produções autorais, quando deixamos de reproduzir o que fizeram conosco e passamos a criar nosso próprio modo de imprimir nossa marca no que fazemos.

\footnotetext{
${ }^{9}$ Paula Carvalho, 1998, p. 66
} 
A narrativa de si emerge como obra inacabada gerada no trajeto antropológico da pessoa em seu constante processo de constituição, na incessante troca de suas pulsões subjetivas e da objetividade de seu meio sócio-cultural.

Ao escrever minha narrativa pude rever e reinterpretar meu percurso formativo, reconhecendo imagens, selecionando palavras e elegendo eventos significativos que constituem minha memória.

Ao escrever tive uma nova oportunidade de produzir um texto que me produzia, revelando-me em minhas repetições, redundâncias e metáforas.

A narrativa de si é aqui apresentada como uma possibilidade hermenêutica, que poderá contribuir para a formação do educador ao ouvirmos a voz do imaginário, entendendo tal possibilidade hermenêutica como descreve Ferreira-Santos ${ }^{10}$ :

Ramo da filosofia que se ocupa da interpretação de textos e discursos, a hermenêutica, sob a égide de Hermes, deus da comunicação, busca compreender, interpretar, traduzir o sentido de uma obra.

(...) Seguindo os passos de Ricoeur, a apropriação de uma obra se dá à distância, uma vez que a própria escrita impõe o distanciamento. Não há mais como estabelecer a intenção do autor, já que o texto ganha vida própria. As objetivações estruturais do texto fazem dele um médium, ou seja, é por meio dele que podemos nos compreender. Isso significa que o sujeito não se conhece por intuição imediata, mas por meio do grande atalho dos sinais de humanidade depositados nas obras de cultura.

A construção do texto, tal como a forja precisa moldar o magma vivo numa forma. As palavras eclodem como a materialização dessas imagens-magma. O passar do tempo necessário para a sua elaboração, permite o distanciamento do "si" ao mesmo tempo que vamos nos aproximando dele, num movimento de forças centrífugas e centrípetas. Numa respiração que permite a troca de ares e de olhares.

Identifico-me aqui com as palavras de Berkenbrock-Rosito quando ao escrever sobre a origem da autoria afirma:

Como a teoria do caos, é a partir da decifração de um enigma, ou de um determinado acontecimento, que jorra a autoria. A fonte da autoria não decifra todo o enigma. A história não acaba nunca. Ao contar, vou me desvelando a mim mesma e ao outro, mostrando o sentido de narrar a história de si no contexto de compreensão de formação estética de

\footnotetext{
${ }^{10}$ Ferreira-Santos \& Almeida, 2012, p.106-107.
} 
professores. Narrar minha história implica pensar a educação estética mergulhada no campo das imagens, demonstrando a fruição do imaginário.

(...) Nessas vivências se vislumbram possibilidades de construir metodologias não convencionais de pesquisa e ensino, religar os aspectos das relações sociais, políticas e culturais nas dimensões macro e micro, construir pontes de sentidos entre a experiência do conhecimento científico do mundo interno e externo dos sujeitos, considerar as possibilidades/limites da formação de professores como cidadãos críticos.

A narrativa, com um valor estético, percebe a singularidade tramada na pluralidade, que emerge não da racionalidade instrumental, fora de si, mas do imaginário. (...) Os dados aleatórios, como na teoria do caos, reorganizam-se, na revelação da saga humana de revelar a minha autoria. Revela-se a importância dos aspectos inconscientes do ser sujeito da história, trazê-los à consciência e assumi-los, na articulação da relação do ser construído historicamente, na relação consigo mesmo, com o outro e com o contexto. ${ }^{11}$

Voltando ao fio condutor desta tese, a experiência do doutorado permitiu-me retornar para os estudos da área temática "Cultura, Organização e Educação". De fato, suas referências sempre estiveram dentro de mim. Mas após a defesa do mestrado, passei quase dez anos dedicandome à minha carreira profissional, na prefeitura municipal de São Paulo.

Acredito que a verdadeira motivação que me impulsionou ao retorno à minha formação acadêmica seja o enredo do mito ou dos mitos que se revelam ao longo da narrativa que descreve minha jornada nos próximos capítulos. Posso adiantar que o retorno aos estudos pela experiência do doutorado, colocou-me em contato com o caminho da busca pela autenticidade, pelo reencantamento pela poiésis criadora: na busca pelo Graal.

Após dez anos em contato com os discursos e práticas originadas das políticas públicas e passando por várias mudanças em minha vida pessoal encorajei-me a mergulhar novamente às raízes frondosas que podem nutrir a alma, como na lenda de Parsifal recontada por Joseph Campbell e Stanley Keleman parodiada a seguir:

O Rei do Graal foi ferido. Como resultado desse ferimento, uma maldição foi lançada sobre toda a terra. O principal tema da aventura do Graal é a existência de uma terra que tornou devastada e deve ser novamente trazida a vida. A vida inautêntica é ferida.

O rei Anfortas (em francês, "o enfermo") é um lindo jovem que não conquistou o título de Senhor do Graal. Ele o herdou. Em sua própria vida, ele não experimentou o preenchimento da sua posição. Um dia, quando está cavalgando, surge à sua frente um cavaleiro pagão, vindo da

\footnotetext{
${ }^{11}$ Berkenbrock-Rosito, 2009, p.491-494.
} 
floresta. Esse cavaleiro é do Islã, da Terra Santa, e representa a natureza. Os dois se enfrentam e o cavaleiro pagão é morto. $O$ homem da natureza é morto pela lança cristã. Porém, a lança do cavaleiro pagão castra o rei. Essa é a ideia do sobrenatural contra a graça natural castrando a natureza. A natureza da Europa contemporânea é a da Terra Devastada, que não vem do corpo, do coração, mas de algum ideal que lhe é imposto.

O rei volta ao castelo com a ponta da lança ainda na ferida. Quando a ponta é removida, nela está escrita a palavra Graal. Isso significa que o ideal espiritual mais elevado está implícito no dinamismo da natureza. O Cavaleiro do Graal terá de ser alguém que age de acordo com a sua natureza, a natureza de um coração nobre. O cavaleiro que é candidato a isso não o sabe. É Parsifal.

No imaginário medieval, o cavaleiro representa o dinamismo da natureza. O cavaleiro representa o controle do cavalo. Mas é somente quando deixa as rédeas soltas no pescoço do cavalo, que o conduz a um castelo no vale. O castelo onde ele entra dessa vez pertence a uma rainha órfã, jovem da sua idade cujo nome é Konduiraours - aquela que conduz ao amor.

Novamente, ele deixa as rédeas soltas no pescoço do cavalo e chega a uma lagoa. Chegamos a esse cenário maravilhoso o castelo do Graal. O Graal é trazido e é um vaso de pedra. Agora, o Graal como o descreve Wolfram, é um vaso de pedra que foi trazido do céu por anjos neutros. $\mathrm{Na}$ guerra do céu, onde os anjos de Satã estavam lutando contra os anjos de Deus, de acordo com Wolfram, também havia anjos neutros. Estes trouxeram o Graal para a terra. 0 caminho entre o par de opostos. Não existe homem bom, não existe homem mau. A bondade e a maldade são relativas, elas não são absolutas. A realização mística abrange o bem e o mal. A religião da Europa é uma religião de polaridade. Deus e Diabo. A realização mística transcende todos os pares de opostos. Você se afasta do próprio centro, não no que se refere ao bem ou ao mal, ao que é útil ou inútil, mas para fora do seu centro. Isso curará o mundo. A única maneira de curar a Terra Devastada é essa transcendência de todos os sistemas conceituais.

Enquanto cavalga, à sua frente, saindo da floresta, surge um cavaleiro pagão. Os dois se enfrentam. Eles derrubam um ao outro dos cavalos. Avançam com suas espadas e a de Parsifal quebra no elmo do cavaleiro e este, quando vê o adversário sem arma, atira longe a própria arma e diz: Eu não luto com um homem desarmado.

Os dois sentam-se e tiram os elmos. Um cavaleiro é negro e o outro, branco. É o irmão de Parsifal. Há uma linda cena de reconhecimento de que o par de opostos é, na realidade, um só.

Então Parsifal diz: Há uma grande festa logo adiante. Talvez você queira desfrutar. Voltamos ao castelo do Graal. O rei está curado. Entra um velho padre carregando uma pia batismal que está vazia. Ele a inclina na direção do Graal e enche-a de água. O nome do Graal é Lapis excilis, um dos nomes da pedra filosofal, que representa o mesmo que o Graal: a união final dos pares de 
opostos nas alturas da realização espiritual transcendente. É isso também o que quer dizer compaixão. A união de um par de opostos. Eu sou você significa paixão entre nós: compaixão.

O Graal representa um alto símbolo elevado de preenchimento espiritual,

Usar a si mesmo de um modo diferente é a chave da sua salvação. Não se importe em mudar o homem velho, o Rei do Graal, a quem falta o preenchimento necessário para sua posição. Não a resposta permanece com Parsifal. O homem velho é afetado pela maneira como Parsifal usa a si mesmo. $^{12}$

Enquanto escrevia a narrativa que constitui o núcleo desta tese, por quantas vezes necessitei alongar meu corpo, que se expressava tanto na dor quanto nos instantes de descoberta, quando ao movimentá-lo ele devolvia imagens, verdadeiros lampejos de lumina profundis: as luzes que vêm de dentro, que vinham da fonte. Do é da "coisa".

Enquanto o presente texto surgia entre páginas e capítulos, esta narrativa refletia um outro texto: a escrita corporal. Memórias carregadas de emoção. Releituras de trechos que me levaram às lágrimas. Transpiração e respiração ofegante todas as vezes que a angústia do desconhecido interrompia a fruição criadora.

Nosso Imaginário está ancorado em nosso corpo. Nossos tecidos possuem memória. Esta memória viva está impressa em nossa corporeidade, queiramos ou não.

Afinal, a moça que iniciara o curso de Pedagogia com dezenove anos, hoje é a mulher de quarenta e um anos. Em cada célula habita parte desta jornada. Quantos corpos tive até hoje? Quantas experiências motoras acumuladas e transformadas pelo aumento ou pela redução da mobilidade corporal? De bebê à mulher atual, quantos corpos habitei? E quantos outros ainda irei herdar de minhas ações presentes?

Ao narrar transitamos num tempo próprio, nem sempre cronológico. Mas nele integramos nosso passado ao presente, e neles vislumbramos um futuro, em todas as vezes que respiramos e tomamos consciência de nós mesmos integralmente. Quando o corpo adoece ele também comunica algo. Da mesma forma, quando saudável engendra a bela dança da vida. Lembremos que o homem velho é afetado pela maneira como Parsifal usa a si mesmo.

E aqui, ressalto o segundo aspecto desta hermenêutica, ao considerar o texto vivo impresso em nosso corpo. No diálogo entre corpo e alma.

Para Keleman:

\footnotetext{
12 Keleman, 2001, p. 73-81.
} 
O reconhecimento do movimento pulsátil do corpo gera imagens e percepções que são o alfa e o ômega dos mitos. A experiência tissular é a sua fundação. As nossas imagens são experiências corporais. Contudo, muitas vezes não estamos conscientes disso. Precisamos cultivá-la, se quisermos entrar no reino humano. A entrada nesse reino proporciona à nossa vida um prazer que transcende a filosofia social e reconhece a verdade da conexão somática. O próprio processo corporal origina o mito. O corpo organiza a sua própria humanidade. Esse é o processo de criação, de transmissão da realidade somática.

O mito pode transformar o que é transparente, que é transcendente, no processo somático. 0 corpo usa seu cérebro para fazer imagens de si mesmo e do mundo. Essas experiências organizadas nos colocam em relação com o nosso corpo e o dos outros. É isso o que eu chamo de referência corporal e o que a literatura chama de pensamento mítico. Pela vida corporal, descobrimos que somos parte de alguma coisa maior do que nós mesmos, algo que é contínuo, apesar de sermos descontínuos. O mito é a voz do corpo tornando-se humano. ${ }^{13}$

Quando afirmei como tese que a narrativa de si constitui um caminho hermenêutico referia-me a esta dupla dimensão humana. A este respeito Silveira Porto sinaliza:

Segundo Morin, a cultura consiste num circuito metabólico, simultaneamente repetitivo e diferencial, entre o pólo das formas estruturantes (physis/bios), a saber, as organizações e instituições - o instituído - no qual manifestam-se códigos, formações discursivas e sistemas de ação, e o pólo do plasma existencial (psyche/noo), dos grupos no sentido estrito, das vivências, dos espaços, da afetividade e do afetual, enfim do instituinte. Em resumo, há polarização, e não dicotomias, localizando-se a cultura nesse anel recursivo (boucle recursive) que estabelece a circulação constante entre ambos os pólos. ${ }^{14}$

Cada pessoa em sua jornada existe a partir da circulação recursiva ${ }^{15}$ destes pólos.

A partir das contribuições de Paula Carvalho ${ }^{16}$ reconhece-se que a narrativa constitui um caminho para abordar os núcleos arquetipais e as constelações mitemáticas emergentes nos relatos das estórias de vida procurando identificar-Ihes "o mito pessoal" e o(s) fragmento(s) que agencia, de tal forma que a vida de uma pessoa é a passagem de um mito e sua progressiva

\footnotetext{
${ }^{13}$ Idem, p. 105

${ }^{14}$ Sanchez Teixeira \& Silveira Porto, 1999, p. 95

${ }^{15}$ Define como recursivo o processo pelo qual uma organização produz elementos e efeitos necessários a sua própria geração ou existência, processo que realiza um circuito, em que o produto ou efeito último torna-se elemento primeiro ou causa primeira. A recursividade subentende uma relação ao mesmo tempo complementar, concorrente e antagonista (Morin, 1977, p. 196).

${ }^{16}$ Paula Carvalho, 1998, p. 10
} 
descoberta, fato que permitirá ver "a medida" em que acolhe e transforma um "legado" a ele imprimindo, inequivocamente, um sentido de "releitura" e "apropriação".

Apropriação que traz o empoderamento da mulher que escreve sua história, dialogando com seus diários da juventude e das linhas que se sucedem no caminhar da mulher que me tornei, e ainda estou me tornando...

Convido o leitor a compartilhar desta jornada que encontrou no caminho, o preenchimento do Graal. Eis a vida, uma contínua busca.

E recorro às palavras de Clarice Lispector ${ }^{17}$ para tornar-me cada vez mais consciente de minha inconsciência.

E não me esquecer, ao começar o trabalho, de me preparar para errar. Não esquecer que o erro muitas vezes se tinha tornado o meu caminho. Todas as vezes em que não dava certo o que eu pensava ou sentia - é que se fazia, enfim, uma brecha, e, se antes ei tivesse tido coragem, já teria entrado por ela. Mas eu sempre tivera medo de delírio e erro. Meu erro, no entanto, devia ser o caminho de uma verdade: pois só quando erro é que saio do que conheço e do que entendo. Se a verdade fosse aquilo que posso entender - terminaria sendo apenas uma verdade pequena, do meu tamanho.

\footnotetext{
${ }^{17}$ A Paixão segundo G.H.
} 


\section{Instante poético e pesquisa autobiográfica}

Como decorrência de minhas vivências ainda na formação inicial como pedagoga, tomei contato com várias vertentes de pesquisa autobiográfica que somente muitos anos depois eu pude verificar o quão profundas as reflexões decorrentes destas vivências se instalaram em $\operatorname{mim}$.

Desde as pesquisas predominantes na área de formação de professores, tendo o portifólio, como instrumento principal e que se desdobram nos encontros da CIPA - Congresso de Investigação e Pesquisa Autobiográfica, cuja predominância se vale dos estudos de Antonio Nóvoa que afirma: "[...] urge por isso (re) encontrar espaços de interação entre as dimensões pessoais e profissionais, permitindo aos professores apropriar-se dos seus processos de formação e dar-Ihes um sentido no quadro das suas histórias de vida"18.

Outra vertente mais fenomenológica são aquelas pesquisas como as de Marie-Christine Josso ${ }^{19}$ e suas atualizações em Margarete Berkenbrock-Rosito ${ }^{20}$, em especial, as atividades formativas com a colcha de retalhos (retalhos de tecido pintados pelos professores em formação com suas referências pessoais e depois dispostos numa única colcha ao modo tradicional) já num exercício de aproximação ao universo dos estudos sobre o imaginário.

Finalmente, as vertentes mais simbólicas e hermenêuticas das histórias de vida, para os quais a obra de Gusdorf ${ }^{21}$ representa um leito principal a partir do qual podemos aprofundar os estudos como em Paula Carvalho ${ }^{22}$, Ricoeur ${ }^{23}$ e Ferreira-Santos ${ }^{24}$ e os diálogos com os estudos durandianos.

A narrativa de si como autobiografia, no que ela possui de "verdadeiro" ou de ficção, não elimina o fato básico de ser sempre um ato poético. Mesmo pensando no "pacto autobiográfico" como propõe Lejeune ${ }^{25}$ em que a autobiografia aparece como uma narrativa em prosa, escrita por uma pessoa real a respeito de sua própria existência, cujo autor, narrador e personagem são as mesmas pessoas e o ponto de vista do narrador é de retrospectiva dentro da própria narrativa. Sendo consciente disso, o próprio autor se comprometeria com a

\footnotetext{
${ }^{18}$ Nóvoa, 1995, p. 25. Vide também Nóvoa, 1988.

19 Josso, 2002 e 2008.

${ }^{20}$ Berkenbrock-Rosito, 2009.

${ }^{21}$ Gusdorf, 1991.

22 Paula Carvalho, 1998a.

23 Ricoeur, 1991 e 1994.

${ }^{24}$ Ferreira-Santos, 1998, 2003 e 2005. Vide também Ferreira-Santos \& Almeida, 2012.

25 Lejeune, 1975 e 2003.
} 
"verdade" da narrativa. E aqui o pacto também exibe os seus limites. Nesse sentido, nos socorre novamente Bachelard:

O poeta destrói a continuidade simples do tempo encadeado para construir um instante complexo, para unir sobre este instante numerosas simultaneidades. Em todo verdadeiro poema, pode encontrar elementos de um 'tempo estancado', de um tempo que não segue a medida (contínua), de um tempo que chamaremos de 'vertical' para distinguir do tempo comum, o qual foge horizontalmente com a água do rio, com o vento que passa. Disto decorre o paradoxo que é necessário enunciar claramente: enquanto o tempo da prosódia é horizontal, o tempo da poesia é vertical. (...) O objetivo - da poesia - é a 'verticalidade', a profundidade ou a altura: o instante estabilizado ou as simultaneidades (desse instante), provam - ordenando-se que o instante é poético possui uma perspectiva metafísica.

O instante poético é pois, necessariamente complexo: comove, demonstra - convida, consola - é surpreendente e familiar. Essencialmente, o instante poético é uma relação harmônica de dois contrários. No instante apaixonado do poeta, há sempre um pouco de razão; na recusa apaixonada, fica sempre um pouco de paixão. As antíteses sucessivas agradam o poeta. Porém, para o encantamento, para o êxito, é preciso que as antíteses reduzam-se a uma ambivalência. Então surge o instante poético... (...) O mistério poético é um feito andrógino. ${ }^{26}$

Nesta mesma perspectiva, Lima nos afirma que a arte como: fixação dos mais altos momentos dos fenômenos, não é uma imitação das coisas físicas, nem simples transbordamento de sentimentos poderosos. É uma interpretação da realidade - não através de conceitos, mas de intuições; não por meio do pensamento, mas das formas sensoriais ${ }^{27}$.

O aspecto sensorial está intimamente ligado às estruturas do corpo que engendram e geram as imagens mais ancestrais como nos atestam a fenomenologia e os estudos durandianos. Deste modo, a narração de si como processo criativo - por isso mesmo, poético - se dá no instante poético e não em sua duração histórica. O contexto histórico nos auxilia a compreender o contexto, mas a obra não se reduz a uma possível biografia. Como inscrição de si mesmo e como obra poética vai além do contexto e dialoga conosco através do que possui de mais vertical e vertiginoso em sua experiência própria.

\footnotetext{
${ }^{26}$ Bachelard apud Lima, 1976, p. 138

${ }^{27}$ Lima, 1976, p. 138.
} 
A dissertação de mestrado de Maria Beatriz Albernaz, intitulada: "A poética na escola - uma tese de ficção ${ }^{\prime 28}$, nos confirma este caráter inovador nas pesquisas educacionais defendendo o espaço da criação literária na escola - espaço mais burocrático que vivencial em muitos casos e que a poesia auxilia tanto professores como alunos. Precisamente, no que tem de mais existencial do que "didático". Diz ela:

além de outras pequenas surpresas e desconcertos [nos textos de Oswald de Andrade] fazem a sua crítica interessante e não didática; já à didática uniu-se a noção de exclusão da valoração estética (o que vem pra ser aprendido exige do leitor, espectador e, claro, do aluno uma parada na leitura da narrativa) ${ }^{29}$.

A autobiografia se vale deste instante poético na medida em que se configura como um gênero literário construído por uma pessoa que quer resgatar, através da escrita, acontecimentos passados em sua memória ${ }^{30}$. Ainda que tal empreendimento possa causar constrangimentos para o autor e para o leitor ${ }^{31}$. Outra possibilidade é a autobiografia ficcional ou autoficção: "Es precisamente en razón del carácter evasivo de la vida real que tenemos necesidad del auxilio de la ficción para organizar esta última retrospectiva extemporânea (...) un misto instable entre fabulación y experiencia viva"32

Serge Doubrovsky, criador do neologismo "autoficção" afirma que esta seria "uma variante 'pós-moderna' da autobiografia, na medida em que ela não acredita mais numa verdade literal, numa referência indubitável, num discurso histórico coerente e se sabe reconstrução arbitrária e literária de fragmentos esparsos de memória"33. A quebra da linha cronológica, bem como a releitura dos "fatos" são admitidos como essenciais pois revelariam a importância simbólica e seus significados libertados da "verdade histórica" ou mesmo das "provas documentais" deixando a criação poética livre no que tem de mais visceral no entrecruzamento com a carga vivencial.

Autobiografia? Não, isto é um privilégio reservado aos importantes deste mundo, no crepúsculo de suas vidas, e em belo estilo. Fiç̧ão, de acontecimentos e fatos estritamente reais; se se quiser, autoficção, por ter confiado a linguagem de uma aventura à aventura da linguagem, fora da sabedoria e fora da sintaxe do romance, tradicional ou novo. Encontro,

\footnotetext{
${ }^{28}$ Albernaz, 1987.

${ }^{29}$ Albernaz, 1987, p. 115.

${ }^{30}$ Carvalho, 2011.

${ }^{31}$ Ginzburg, 2009.

32 Ricoeur, 1991 apud Ferreira-Santos, 2010, p. 234.

33 Doubrovsky, 1977.
} 
fios de palavras, aliterações, assonâncias, dissonâncias, escrita de antes ou de depois da literatura, concreta, como se diz em música. Ou ainda: autofriç̧ão, pacientemente onanista, que espera agora compartilhar seu prazer ${ }^{34}$.

Ainda na vertente da autoficção há também a possibilidade de uma autoficção fantástica ${ }^{35}$ em que o autor transpõe sua identidade no irreal e a amplia para além dos limites humanos sem estabelecer correspondências entre a ficção e a biografia, sendo a invenção seu caráter mais importante, assim como a própria poesia.

Neste contexto é que transcrevo a seguir o conto africano "Carne de Língua" na íntegra, para que possamos ao longo da narrativa degustá-lo em suas metáforas tão ligadas ao meu momento pessoal e profissional como uma autobiografia fantástica que "perguntar carece: como não fui eu que fiz?"36.

\footnotetext{
${ }^{34}$ Doubrovsky, quarta capa, 1977.

${ }^{35}$ Colonna, 2004.

${ }^{36}$ Verso da canção "Certas Canções", autoria de Milton Nascimento e Fernando Brandt
} 


\section{Carne de Língua}

\section{(Conto Africano contado por llan Brenman)}

Há muito, muito tempo, existiu um rei que se apaixonou perdidamente por uma rainha. Depois do casamento, ela foi morar no castelo do rei, mas, assim que pisou lá, misteriosamente ficou doente. Ninguém sabia por que a rainha havia adoecido; o fato, porém é que ela definhava a cada dia. O dono da coroa, que era muito rico e poderoso, mandou chamar os melhores médicos do mundo. Eles a examinavam, mas não descobriram a causa da doença. O rei, então, mandou chamar os curandeiros mais famosos do mundo. Fizeram preces, prepararam poções e magias. Também não adiantou nada. A rainha emagrecia diariamente - dali a pouco desapareceria por completo.

O rei, que amava sua esposa tão imensamente decidiu:

- Eu mesmo vou procurar a cura para a doença da minha rainha.

E lá foi ele procurar a cura para a sua rainha. Andou por cidades e campos. Num desses campos avistou uma cabana. Ao chegar perto, aproximou o rosto da janela e viu, lá dentro, um casal de camponeses. O camponês mexia os lábios e, na frente dele, a camponesa, gordinha e rosadinha, não parava de gargalhar. Os olhos daquela mulher transbordavam felicidade.

O rei começou a pensar:

- O que será que faz essa mulher ser tão feliz assim?

Com essa pergunta na cabeça, ele respirou fundo e bateu à porta da cabana.

- Majestade! O que o nosso rei deseja? - perguntou o súdito, um pouco assustado com a presença real à sua frente.

- Quero saber, camponês, o que você faz para sua mulher ser tão feliz e saudável? A minha rainha está morrendo no castelo, toda tristonha.

- Muito simples, Majestade: alimento a minha mulher todos os dias com carne de língua.

O visitante pensou que tivesse ouvido errado: carne de língua! O morador da cabana repetiu:

- Alimento minha esposa diariamente com carne de língua.

A situação era de vida ou morte. O rei, mesmo achando aquilo meio estranho, agradeceu ao homem do campo e foi correndo de volta para o castelo. Chegando lá, mandou chamar imediatamente à sua presença o cozinheiro real:

- Cozinheiro, prepare já um imenso sopão com carne de língua de tudo o que é animal vivente na Terra. 
- O que?! Como assim, Vossa Majestade? - estranhou o chefe da cozinha real, com um ponto de interrogação no rosto.

- Você ouviu direito! Carne de língua de todos os animais do reino! Corra, porque a rainha não pode mais esperar.

O cozinheiro foi chamar os caçadores do reino. Passadas algumas horas, ele tinha à sua frente línguas de cachorro, gato, rato, jacaré, elefante, tigre, girafa, lagartixa, tartaruga, vaca, ovelha, zebra, hipopótamo, sapo, coelho...

No meio da noite, a nova sopa já estava pronta no caldeirão. O próprio rei foi alimentar a rainha com carne de língua. Entrou no quarto e ficou espantado a aparência dela. Sentou-se ao lado, pegou uma colher do sopão e a aproximou da boca de sua amada esposa. Com muito esforço, ela engoliu algumas colheradas daquela comida exótica.

o rei esperou, esperou e esperou, mas a rainha não melhorava - muito pelo contrário, parecia que a morte a levaria a qualquer momento. Cansado de esperar, ele se desesperou. Se não fizesse algo, sua mulher iria embora para sempre.

- Soldado! Soldado! - gritou.

Um homem enorme, com armadura e espada, entrou no quarto.

- Escute bem, soldado. A rainha tem que ser transferida imediatamente para a casa de um camponês. Lá você encontrará em mulher gordinha e rosadinha; quero que a traga até aqui.

Então explicou ao soldado onde ficava a casa desse homem do campo. Essa era a única chance, ele imaginava, de a mulher sobreviver. Mas talvez o rei não tivesse entendido direito o que o camponês Ihe dissera.

- Corre, corre soldado! A vida da rainha depende disso!

O soldado pegou a rainha no colo e com a ajuda de outros homens saiu em disparada até a casa no campo. A troca foi feita e, assim que a camponesa entrou no castelo, adoeceu misteriosamente. Depois de três semanas, aquela mulher, que era gordinha e rosadinha, estava magra e triste. O rei, então, decidiu ver como estava sua esposa.

Chegando na cabana, pôs o rosto na janela e... Não podia ser! A rainha estava gordinha, rosadinha e gargalhava como nunca se vira antes. À sua frente, o camponês não parava de mexer os lábios. O rei bateu à porta:

- Novamente por aqui, Majestade! O que deseja?

- Camponês, o que está acontecendo!? A sua esposa está morrendo no meu castelo e a minha está toda feliz e saudável aqui na nossa frente.

- Me diga, Vossa Majestade: o que fez? 
- Fiz exatamente o que você mandou. Dei carne de língua de cachorro, gato, sapo, coelho, girafa... para minha rainha e para sua esposa também. Mas, caro súdito, de nada adiantou.

- Vossa Majestade não compreendeu o que eu disse - riu-se o homem do campo. Eu alimentei a rainha e a minha esposa com carne de língua: as histórias contadas pela minha língua.

Sua Majestade meditou um pouco sobre aquelas palavras. Lembrou-se também dos lábios daquele homem se mexendo. Parecia que agora havia entendido. Chamou sua esposa de volta e mandou a camponesa de volta para sua casa. Assim que a rainha entrou no castelo, o rei prometeu que lhe daria todas as noites, antes de dormir, carne de língua.

A partir daquele dia, contam os quenianos, o rei contava uma história diferente todas as noites. Esse povo africano nos revelou que nunca mais a rainha ficou doente. Ensinaram-nos um segredo: as histórias fazem muito bem para as mulheres, homens, crianças, jovens, velhos - e até mesmo para os reis.

A importância das histórias para a condição humana destacada no conto pode se aproximar à origem divina da "Palavra" descrita por Amadou Hampaté Bá37 a seguir:

Como não posso discorrer com autenticidade sobre quaisquer tradições que não tenha vivido ou estudado pessoalmente - em particular as relativas aos países da floresta - tirarei os exemplos em que me apoio das tradições da savana ao sul do Saara (que antigamente era chamada de Bafur e que constituía as regiões de savana da antiga África ocidental francesa).

A tradição bambara do Komo ensina que a Palavra, Kuma, é uma força fundamental que emana do próprio Ser Supremo, Maa Ngala, criador de todas as coisas. Ela é o instrumento da criação: "Aquilo que Maa Ngala diz, é!" proclama o chantre do deus Komo.

O mito da criação do universo e do homem, ensinado pelo mestre iniciador do Komo (que é sempre um ferreiro) aos jovens circuncidados, revela-nos que quando Maa Ngala sentiu falta de um interlocutor, criou o primeiro Homem: Maa.

Antigamente, a história da gênese costumava ser ensinada durante os 63 dias de retiro imposto aos circuncidados aos 21 anos de idade estudando-a cada vez mais profundamente.

$\mathrm{Na}$ orla do bosque sagrado, onde Komo vivia, o primeiro circuncidado entoava ritmadamente as seguintes palavras:

“Maa Ngala! Maa Ngala!

\footnotetext{
${ }^{37}$ Hampate-Ba, 2010.
} 
Quem é Maa Ngala?

Onde está Maa Ngala?

O chantre do Komo respondia:

Maa Ngala é a Força Infinita.

Ninguém pode situá-lo no tempo e no espaço.

Ele é Dombali (Incognoscível)

Dambali (Incriado - Infinito)

Então, após a iniciação, começava a narração da gênese primordial:

Não havia nada, senão um Ser.

Este Ser era um Vazio vivo,

A incubar potencialmente as existências possíveis.

O Tempo infinito era a moradia desse Ser-Um.

O ser-Um chamou-se de Maa Ngala.

Então ele criou Fan,

Um Ovo maravilhosos com nove divisões

No qual introduziu os nove estados fundamentais da existência. Quando o Ovo primordial chocou, dele nasceram vinte seres fabulosos que constituíram a totalidade do universo, a soma total das forças existentes do conhecimento possível. Mas ai!, nenhuma dessas vinte primeiras criaturas revelou-se apta a tornar-se o interlocutor (kuma-nyon) que Maa Ngala havia desejado para si.

Assim ele tomou de uma parcela de cada uma dessas vinte criaturas existentes e misturouas; então, insuflando na mistura uma centelha de seu próprio hálito ígneo, criou um novo Ser, o Homem, aquém deu uma parte de seu próprio nome: Maa. E assim esse novo ser, através de seu nome e da centelha divina nele introduzida, continha algo do próprio Maa Ngala.

Síntese de tudo o que existe, receptáculo por excelência da Força suprema e confluência de todas as forças existentes, Maa, o Homem, recebeu de herança uma parte do poder criador divino, o dom da Mente e da Palavra.

Maa Ngala ensinou a Maa, seu interlocutor, as leis segundo as quais todos os elementos do cosmo foram formados e continuam a existir. Ele o intitulou guardião do Universo e o encarregou de zelar pela conservação da Harmonia universal. Por isso é penoso ser Maa.

Iniciado por seu criador, mais tarde Maa transmitiu a seus descendentes tudo o que havia aprendido, e esse foi o início da grande cadeia de transmissão oral iniciatória da qual a ordem do Komo (como as ordens do Nama, do Kore, etc., no Mali) diz-se continuadora.

Tendo Maa Ngala criado seu interlocutor, Maa, falava com ele e, ao mesmo tempo, dotavao da capacidade de responder. Teve início o diálogo entre Maa Ngala, criador de todas as 
coisas, e Maa, simbiose de todas as coisas. Como provinham de Maa Ngala para o homem, as palavras eram divinas porque ainda não haviam entrado em contato com a materialidade. Após o contato com a corporeidade, perderam um pouco de sua divindade, mas se carregaram de sacralidade. Assim, sacralizada pela Palavra divina, por sua vez a corporeidade emitiu vibrações sagradas que estabeleceram a comunicação com Maa Ngala. A tradição africana, portanto, concebe a fala como um dom de Deus. Ela é ao mesmo tempo divina no sentido descendente e sagrada no sentido ascendente.

No conto Carne de Língua, podemos acompanhar o poder sagrado da Palavra: aquela que pode regenerar o reino devastado, numa relação do Uno para o Todo. Regenerar a narrativa pessoal e de suas ressonâncias coletivas, percebendo também na lição bambara de Hampate Bá a dupla ligação entre o humano e o sagrado na própria experiência da palavra. 


\section{Do Reino Devastado e de Sua Regeneração}

Contextualizando a escolha do conto "Carne de Língua", ela "objetivamente" estava relacionada, inicialmente, ao Projeto Político Pedagógico da escola.

Como o foco principal do projeto pedagógico era qualificar as vivências de literatura e brincadeira, estava trabalhando a importância da leitura, especialmente apresentando contos de culturas diferentes para compartilhar com o grupo de professores. Avaliações anteriores realizadas na escola, envolvendo todos os seus segmentos, (Indicadores de Qualidade para a Educação Paulistana) apontaram para a necessidade de investirmos num trabalho que destacasse nossas raízes afro-brasileiras.

Vale detalhar que a utilização dos Indicadores da Qualidade na Educação Infantil Paulistana é produto de um processo instaurado na Rede Municipal de Ensino de São Paulo - RME-SP, desde setembro de 2013, que visa promover uma prática de avaliação institucional participativa nos Centros de Educação Infantil - CEl diretos, indiretos, conveniados, no Centro Municipal de Educação Infantil - CEMEI e nas Escolas Municipais de Educação Infantil - EMEI.

Conhecendo a variedade do acervo escolar, sempre proponho durante as reuniões pedagógicas, apresentar os materiais existentes na escola para que as professoras possam compartilhar com as crianças.

Para isso, durante a reunião realizamos vivências de leitura, brincadeiras e musicalização. Preparei como vivência um ambiente inspirado na cultura africana, objetos, livros e música, mas não me satisfiz em compartilhar objetos e livros apenas da escola. Desta vez, decidi levar coisas que se encontravam em minha casa para compartilhar com o grupo.

Desde o livro escolhido, tecidos para ambientar a sala na qual realizamos a reunião, a cantiga Allunde Alluia (interpretada pelo grupo Mawaca) e uma pequena escultura africana de uma mulher acompanhada de uma criança.

Comprei esta escultura logo que ingressei no cargo de coordenadora pedagógica com o objetivo de ornamentar a sala na qual trabalhava. Porém, acabei gostando tanto da imagem que decidi mantê-la em minha casa. Após tantos anos, decidi levá-la para a escola ainda que fosse apenas para a reunião.

Também selecionei um baú coberto por imagens de temas africanos que também já tinha utilizado em uma vivência durante o curso da professora Regina Machado ao ministrar a 
disciplina "As narrativas da Tradição Oral e a Formação de Educadores Artistas" na Escola de Comunicação e Artes da USP durante o Doutorado.

A diferença é que naquela ocasião, levei o baú vazio, numa alusão aos contos que ainda iria conhecer. E para a reunião pedagógica, coloquei dentro dele livros que remetiam aos contos africanos, especialmente "As Narrativas de um Contador de Histórias"38 e "De todos os Cantos do Mundo" do grupo Mawaca ${ }^{39}$. Este último acompanhado de um CD de cantigas.

Após colocar todos os objetos escolhidos cuidadosamente em uma grande bolsa, fui tomada por uma forte emoção, talvez somente agora estivesse pronta para compartilhar aquela escultura: uma mulher adulta acompanhada de uma criança. $\mathrm{O}$ encontro de gerações que remonta a finalidade da educação: a iniciação das futuras gerações.

Era como se estivesse iniciando outra forma de me relacionar com as pessoas do grupo, mas principalmente comigo mesma.

Urgia a necessidade de que minha identidade estivesse mais marcada no processo de formação ali compartilhado.

À medida que os participantes da reunião, iam chegando já eram recebidos com a cantiga africana. Algumas professoras chegaram a verbalizar: Nossa! Que música gostosa! - Que clima aconchegante!

Outras professoras, conversavam paralelamente, mas de forma discreta. Pareciam curiosas.

Após a cantiga, iniciei a leitura do conto Carne de Língua.

O grupo ouviu atentamente, não houve resistências visíveis. Senti que ao ouvir a história, as professoras e a equipe de funcionários em geral acompanharam o conto, algumas vezes ensaiando antecipações do que poderia acontecer, quando na leitura, eu criava momentos de suspense.

Vale destacar, que sempre convidei todos os funcionários da escola para participarem das reuniões pedagógicas. Procuro sensibilizar a equipe gestora sobre a importância do envolvimento de todos os segmentos da escola.

Nem sempre foi possível garantir a presença de todos, já que a direção indicava outras prioridades, seja no atendimento à secretaria, na limpeza, na organização dos almoxarifados ou outras demandas.

Esta situação caracteriza uma das grandes contradições entre os aspectos administrativos e pedagógicos da gestão.

\footnotetext{
${ }^{38}$ Brenman, 2007, p.11

39 Prieto, H. 2008, p. 16
} 
Alguns diretores não reconhecem a necessidade de estarem presentes durante a reunião pedagógica, de participar das vivências e do planejamento das reuniões, delegando completamente este trabalho ao coordenador pedagógico.

Sempre compartilho com a direção a pauta pedagógica com antecedência, procurando articular os temas administrativos e pedagógicos contando com a participação da direção. Mas algumas vezes, torna-se evidente uma fragmentação na condução destes assuntos, de um lado a direção e do outro a coordenação pedagógica.

Porém, nestas duas situações - quando li o conto Carne de Língua e quando confeccionamos as bonecas Abayomis, tanto a diretora como sua assistente, permaneceram até o fim das vivências.

Também contei com a participação de algumas funcionárias da equipe de limpeza e da secretaria. Nas duas situações demonstraram interesse, principalmente na vivência de confecção de bonecas, quando relataram o desejo de aprenderem a fazer as bonequinhas.

Em relação à oficina de confecção das bonecas, também contei com a participação de duas professoras, na preparação e na realização da oficina, tendo em vista, que foi uma delas que sugeriu este trabalho, a partir de suas experiências. A outra professora ofereceu-se para participar de uma oficina de confecção de abayomis, que aconteceu numa Fábrica de Cultura, para enriquecer o momento da realização das bonecas.

Comprei os materiais muito animada e as professoras também me auxiliaram na sugestão dos tecidos e no preparo prévio da vivência.

Compartilhei a condução da oficina, contando com a participação destas professoras. Minha maior dificuldade foi conseguir terminar este momento da oficina, porque ninguém queria parar de fazer as bonecas. Foi um momento muito divertido. E enfrentar a pauta, nem sempre é algo tão agradável, quanto vivenciar um momento lúdico de criação. Especialmente, porque nestes escassos momentos de reunião, envolvendo o coletivo da escola, temos que tratar de um volume muito grande de assuntos, e ao tratá-los deparamo-nos com situações de conflito.

Com relação à sugestão das professoras realizarem esta oficina com as crianças, algumas manifestaram empolgadamente interesse, reconhecendo a possibilidade das crianças confeccionarem as bonecas, e especialmente, pela importância de aprenderem a criar seus próprios brinquedos.

Um outro grupo de professoras não apresentou a mesma disposição para a realização da oficina pelas crianças (embora tivessem gostado de fazer as bonecas, durante a oficina estavam 
animadas). Mas ainda assim, o convite foi mantido a todas, garantindo-se o material para a viabilização das oficinas.

Este é um outro aspecto delicado do trabalho da coordenação pedagógica, encontrar o equilíbrio entre liderar de maneira democrática ou autoritária. Alguns defenderiam um consenso, provavelmente uma votação para garantir que todas as turmas fizessem as mesmas coisas. Mas, preferi dividir a escolha com as professoras, respeitando a opção de cada uma delas, pois seria contraditório "obrigar a quem não demonstrou interesse" em realizar a oficina. De outro lado, surge a angústia, em não se garantir que todas as crianças tivessem suas bonecas. Disto, surgiu a sugestão de se confeccionar outros brinquedos com materiais de sucata, partindo da habilidade de cada uma das professoras.

Foi uma solução provisória produtiva. E assim, conduzimos nossa volumosa pauta pedagógica, sem maiores conflitos. A reunião foi bastante produtiva de um modo geral. E eu fiquei muito satisfeita com aquele lúdico momento compartilhado, no qual fomos um pouco crianças enquanto fazíamos nossas bonecas.

Retomando a vivência do conto "Carne de Língua", após lê-lo também disponibilizei vários livros do acervo literário da escola e também do meu acervo pessoal para os participantes. Porém não foram todas as professoras que incluíram estes títulos nas sessões de leituras, que estávamos planejando. Sabemos do tempo necessário à apropriação de cada um. Este era um dos meus objetivos, iniciar um ciclo de formação literária atenta à diversidade cultural.

A ideia era de trocarmos indicações literárias para repertoriar as crianças com títulos que atendessem a diversidade de nossa cultura, considerando a rica contribuição dos contos indígenas e africanos.

O conto "Carne de Língua" objetivamente trata da importância das histórias para as pessoas em geral. Porém, relendo o conto, ao distanciar-me da situação narrada, observei uma série de outras possíveis razões para sua escolha.

Uma delas, a força criadora do Imaginário que no trajeto antropológico das pessoas as produz em seu diálogo objetivo com o cotidiano. Nossas escolhas são fruto desta pulsão. A imagem me escolhera. O conto havia me chamado. A voz era de minha própria alma.

Foi Gilbert Durand quem estudou em profundidade, não só conceituando-o, mas principalmente compreendendo sua dinâmica criadora e organizadora, o que possibilitou estabelecer uma classificação, uma arquetipologia geral do imaginário. (...) Com o conceito antropológico, Durand se coloca em uma perspectiva antropológica globalizante, que 
considera a força fundamental de ligação dos símbolos, superando assim as contradições, os elementos inconciliáveis: a coincidentia oppositorum.

[...] Portanto, o imaginário considera que não há anterioridade nem prevalência, quer do dado pulsional, subjetivo, quer do dado social, objetivo, na formação das imagens. Há uma gênese recíproca que oscila das pulsões ao meio ambiente material e social e deste àquelas, de modo reversível.

O imaginário pode ser definido como "o conjunto das imagens e relações de imagens que constitui o capital pensado do homo sapiens - aparece-nos como o grande denominador fundamental onde se vêm encontrar todas as criações do pensamento humano".

A abrangência do conceito é expressa tanto por conjunto de imagens e todas as criações do pensamento humano - que engloba a produção poética, artística, mas também científica, filosófica, ideológica etc. - quanto por relações de imagens e grande denominador fundamental, que desloca a questão dos produtos da imaginação para o caráter processual do imaginário. Com efeito, o imaginário se define mais por seu aspecto dinâmico, figurativo, que por sua base estrutural.

[...] A obra fundamental para os estudos do imaginário são as Estruturas Antropológicas do Imaginário, tese de Doutorado de Gilbert Durand publicada em 1960 e que apresenta um estudo crítico sobre as abordagens até então realizadas sobre o tema, a definição teórica do imaginário e seu funcionamento, uma proposta de classificação arquetipológica e uma síntese da função fantástica do imaginário.

Para José Carlos de Paula Carvalho, a "teoria geral do imaginário deverá pensar as profundas motivações das elaborações imaginárias, assim como as funções do imaginário, suas estruturas e passos de análise. Sinteticamente, diríamos que o Imaginário - concebido como o universo das configurações simbólicas e das práticas sócio-simbólicas, culminando na dinâmica sócio-cultural e organizacional dos mitos, pois o aparelho simbólico encontra no mito, e em suas elaborações societais, a dinâmica e o epicentro - tem sua razão de ser na reação contra a angústia do tempo e da morte. (...) Apresentará fundamentalmente a função de equilibração antropológica".

De acordo com Durand, a imaginação, e mais amplamente o imaginário, realiza uma função de esperança, de equilibração do mundo. O contato do homem com o tempo que passa e aproxima de seu fim é fonte de angústia existencial, expressa-se por imagens de animalidade terrificante, negatividade insaciável do destino e da morte, imagens sob o signo das trevas, da feminilidade e, por fim, da queda. Como disse Durand, "A carne, esse animal que vive em nós, conduz sempre à meditação do tempo". É dessa meditação que irrompe a perlaboração da angústia existencial do homem diante do tempo e da morte. 
A equilibração que o imaginário realiza pode tanto combater a morte e o tempo como inverter a sua negatividade inicial. Outra estratégia do imaginário é esquecer ou dominar o tempo, aniquilar sua fatalidade ou acelerar o seu fim. Diante do tempo, a função fantástica do imaginário eufemiza a angústia existencial e o homem encontra o lenitivo para sua finitude nas imagens que projeta ao mundo e que dele recebe, como num círculo sem começo ou fim.

O imaginário, portanto, tem a função de restabelecer o equilíbrio vital, psicossocial, antropológico, por meio da criação e circulação de imagens, símbolos e mitos.

Por fim, é importante ressaltar que o imaginário não é um duplo do real, não se opõe a ele ou busca simplesmente representa-lo; pelo contrário, o imaginário é organizador do real. Isso significa que, em si, o real é insignificante, preso à insistematízável singularidade, incólume a qualquer tentativa de interpretação. Esse dado trágico do real, sua total indiferença à tentativa humana de compreendê-lo, não nos impede, no entanto, de organizá-lo, de dotá-lo de sentidos, de buscar compreende-lo. É o que realiza o imaginário. Sua função eufemizadora possibilita que nos situemos no real, ao organizá-lo imaginariamente por meio de narrativas simbólicas ${ }^{40}$.

Após um ano de intenso trabalho na coordenação pedagógica, entre 2014 e 2015, na transição entre os meus quarenta e quarenta e um anos, relendo páginas de minha história, pergunto-me sobre o sentido da própria vida. Percebi o quanto minha atuação profissional ocupou ao longo do tempo um importante papel na atribuição do sentido de estar viva.

Na retomada da narrativa, novamente ressurge, ainda mais forte, a imagem da cigana que dança. Dançando com ela, retomo a narração da jornada pelos caminhos da memória. Emoção, o que me coloca em movimento - a cigana que dança girando sobre seu próprio eixo em ressonância com o caminho de dentro.

O movimento gerado em sua dança, sua sensualidade, sua recorrente expressão de força feminina, impulsionaram-me a quebrar o silêncio e a apatia. Ao longo do ano de 2015, vivi momentos na coordenação pedagógica que me levaram a muitos questionamentos acerca das limitações do trabalho realizado na escola pública.

Uma sensação de indignação face às contradições das políticas públicas e de angústia diante da constatação do baixo reconhecimento do trabalho realizado pelo profissional atuante na educação.

\footnotetext{
${ }^{40}$ Ferreira-Santos \& Almeida, 2012, pp. 37-42.
} 
Num contexto histórico conjuntural, fortemente marcado por grande tensão política, no qual tenho assistido ao longo dos últimos anos, a banalização da formação do pedagogo.

Em geral, as graduações em Pedagogia, nem sempre oportunizam vivências, em termos das práticas que efetivamente os futuros professores irão realizar em sua atuação.

Como formadora, sendo professora num curso de Pedagogia numa universidade particular e coordenadora pedagógica na rede municipal de São Paulo, posso acompanhar a renovação dos quadros dos profissionais de educação, num cenário extremamente contraditório.

Especialmente, na Educação Infantil, ao longo deste último ano, em nome do acesso das crianças ainda não atendidas pela rede municipal, tivemos o fechamento de muitos espaços, tais como salas de leitura, de vídeo e de artes. Na escola em que atuo como coordenadora pedagógica, apesar de reconhecer o direito das crianças ao acesso à Educação Infantil, eu senti uma sensação de frustração ao ver dois espaços alternativos da escola (sala de vídeo e atelier de artes), transformados em duas novas salas de aula.

A necessidade de se atender a demanda de crianças que estão fora da escola, sobrepõe-se aos projetos de qualificação das práticas pedagógicas a serem construídas, uma vez que ainda atuamos com trinta e cinco crianças em turmas de Educação Infantil em pleno século XXI, na maior metrópole de nosso país.

A contradição entre uma proposta assistencialista e um projeto educacional qualificado para as reais necessidades das crianças, persegue o cotidiano escolar. Tanto os gestores escolares, como os professores e os funcionários em geral, vivem pressionados entre as reais condições de trabalho e seus anseios em oferecer uma educação de maior qualidade.

Ocupando o papel de coordenadora pedagógica vivo a tensa relação de reconhecer os limites e cultivar as possibilidades para a melhoria do trabalho realizado na escola.

Apesar desta sensação de esgotamento das perspectivas institucionais estávamos realizando várias ações no tecido sutil do cotidiano. O projeto de plantio contando com a participação das crianças, oficinas de bonecas africanas, sessões de leitura, brincadeira e musicalização e empréstimo de livros. Também realizamos uma festa junina após muitos anos sem esta vivência com a participação da comunidade.

A dança da cigana associa-se à força do imaginário trazendo um sopro de vida ao dia-a-dia. Criando meios de oxigenar o cotidiano, experimentando novas possibilidades, escutando as sugestões das professoras e da comunidade ia dando novas formas à matéria viva, ainda quando ela escapara pela curta duração do instante. 
Apenas pela poética do instante, ao ouvir as autênticas vozes das crianças que esse cotidiano preenchia-se de sentido. Alimentar meu desejo em comunhão com as professoras e crianças passou a ser minha aprendizagem diária. Aprender a lidar com a minha ansiedade, harmonizar rítmicas, articular propostas como apostas vivas de reencantamento de um reino aparentemente devastado.

Mas no fundo das aparências, a potência da criação habita cada um de seus participantes. Histórias de pessoas perseverantes, diferentes e em momentos diversos de suas jornadas. $\mathrm{Na}$ teia do dia-a-dia fomos aprendendo a conviver com nossas dificuldades. No plasma existencial da cultura instituinte nos reinventamos para além dos decretos e portarias nem sempre ouvintes das necessidades da escola.

A escolha do conto também refletia outra dimensão vivida: a necessidade de nutrição, criação, poética.

Apenas envolvidos no calor da criação do que forjamos podemos regenerar este reino. 0 reino que habita cada um de nós. Descobrir a linguagem que nos comunica, que generosamente nos liberta do estado de solidão. Comunicando-nos, permitindo-nos garantir o diálogo do homo ludens, do homo faber, do homo sapiens e do homo demens: assim é que o imaginário, portanto, tem a função de restabelecer o equilíbrio vital, psicossocial, antropológico, por meio da criação e circulação de imagens, símbolos e mitos, como afirmam Ferreira-Santos \& Almeida ${ }^{41}$.

A escola de educação infantil descrita nos documentos oficiais, tais como as Diretrizes e os Referenciais Curriculares Nacionais para a Educação Infantil legitima o espaço do brincar, do criar, de movimentar o corpo, de produzir cores, sabores, texturas e formas. Mas em termos estruturais, ainda temos que lutar pela melhoria das condições de trabalho, buscando um número de crianças por educador mais coerente com um trabalho voltado para a infância. Também temos que investir num processo de formação dos professores no qual a arte, a corporeidade e o lúdico estejam mais presentes em suas diversas linguagens, pela vivência destas experiências pelos educadores.

Neste aspecto, retomo o conto "Carne de Língua" para fazer uma analogia ainda mais ampla, ao compararmos as sociedades tradicionais com as modernas. Lembrei-me das considerações de Amadou Hampaté Bá ao tratar das características da cultura tradicional africana, suas múltiplas facetas, a oralidade, mitologia, religiosidade e formas de expressão:

\footnotetext{
${ }^{41}$ 2012, p.42.
} 
Quando falamos de tradição em relação à história africana, referimo-nos à tradição oral, e nenhuma tentativa de penetrar a história e o espírito dos povos africanos terá validade a menos que se apoie nessa herança de conhecimentos de toda a espécie, pacientemente transmitidos de boca a ouvido, de mestre a discípulo, ao longo dos séculos. Essa herança ainda não se perdeu e reside na memória da última geração de grandes depositários, de quem se pode dizer são a memória viva da África.

Entre as nações modernas, onde a escrita tem precedência sobre a oralidade, onde o livro constitui o principal veículo da herança cultural, durante muito tempo julgou-se que povos sem escrita eram povos sem cultura. Felizmente, esse conceito infundado começou a desmoronar após as duas últimas guerras, graças ao notável trabalho realizado por alguns dos grandes etnólogos do mundo inteiro. Hoje, a ação inovadora e corajosa da Unesco levanta ainda um pouco mais o véu que cobre os tesouros do conhecimento transmitidos pela tradição oral, tesouros que pertencem ao patrimônio cultural de toda a humanidade.

Para alguns estudiosos, o problema todo se resume em saber se é possível conceder à oralidade a mesma confiança que se concede à escrita quando se trata do testemunho de fatos passados. No meu entender, não é esta a maneira correta de se colocar o problema. O testemunho, seja escrito ou oral, no fim não é mais que o testemunho humano, e vale o que vale o homem.

Não faz a oralidade nascer a escrita, tanto no decorrer dos séculos como no próprio indivíduo? Os primeiros arquivos ou bibliotecas no mundo foram o cérebro dos homens. Antes de colocar seus pensamentos no papel, o escritor ou o estudioso mantém um diálogo secreto consigo mesmo. Antes de escrever um relato, o homem recorda os fatos tal como Ihe foram narrados ou, no caso de experiência própria, tal como ele mesmo os narra.

Nada prova a priori que a escrita resulta em um relato da realidade mais fidedigno do que o testemunho oral transmitido de geração a geração. As crônicas das guerras modernas servem para mostrar que, como se diz, (na África), cada partido ou nação "enxerga o meiodia da porta de sua casa" - através do prisma das paixões, da mentalidade particular, dos interesses ou, ainda, da avidez em justificar um ponto de vista. Além disso, os próprios documentos escritos nem sempre se mantiveram livres de falsificações ou alterações, intencionais ou não, ao passarem sucessivamente pelas mãos dos copistas - por detrás do fenômeno que originou, entre outras, as controvérsias sobre as "Sagradas Escrituras". O que se encontra por detrás do testemunho, portanto, é o próprio valor do homem que faz o testemunho, o valor da cadeia de transmissão da qual ele faz parte, a fidedignidade das memórias individual e coletiva e o valor atribuído à verdade em uma determinada sociedade. Em suma: a ligação entre o homem e a palavra. 
É, pois, nas sociedades orais que não apenas a função da memória é mais desenvolvida, mas também a ligação entre o homem e a Palavra é mais forte. Lá onde não existe a escrita, o homem está ligado à palavra que profere. Está comprometido por ela. Ele é a palavra, e a palavra encerra um testemunho daquilo que ele é. A própria coesão da sociedade repousa no valor e no respeito pela palavra. Em compensação, ao mesmo tempo, que se difunde, vemos que a escrita pouco a pouco vai substituindo a palavra falada, tornando-se a única prova e o único recurso; vemos a assinatura tornar-se único compromisso reconhecido, enquanto laço, sagrado e profundo que unia o homem à palavra desaparece progressivamente para dar lugares a títulos universitários convencionais.

Nas tradições africanas - pelo menos nas que conheço e que dizem respeito a toda a região de savana ao sul do Saara - , a palavra falada se empossava, além de um valor moral fundamental, de um caráter sagrado vinculado à sua origem divina e às forças ocultas nela depositadas. Agente mágico por excelência, grande vetor de "forças etéreas", não era utilizada sem prudência.

Inúmeros fatores - religiosos, mágicos ou sociais - concorrem, por conseguinte, para preservar a fidelidade da transmissão oral. Pareceu-nos indispensável fazer ao leitor uma breve explanação sobre esses fatores, a fim de melhor situar a tradição oral africana em seu contexto e esclarecê-la, por assim dizer, a partir do seu interior.

Se formulássemos a seguinte pergunta a um verdadeiro tradicionalista (o termo tradicionalista significa, aqui, detentor do conhecimento transmitido pela tradição oral) africano: "O que é tradição oral?", por certo ele sentiria muito embaraçado. Talvez respondesse simplesmente, após longo silêncio: "é o conhecimento total".

O que, pois, abrange a expressão "tradição oral"? Que realidades veicula, que conhecimentos transmite, que ciências ensina e quem são os transmissores?

Contrariamente ao que alguns possam pensar, a tradição oral africana, com efeito, não se limita a histórias e lendas, ou mesmo relatos mitológicos ou históricos, e os griots estão longe de ser seus únicos guardiões transmissores qualificados.

A tradição oral é a grande escola da vida, e dela recupera e relaciona todos os aspectos. Pode parecer caótica àqueles que não the descortinam o segredo e desconcertar a mentalidade cartesiana acostumada a separar tudo em categorias bem definidas. Dentro da tradição oral, na verdade, o espiritual e o material não estão dissociados. Ao passar do esotérico para o exotérico, a tradição oral consegue colocar-se ao alcance dos homens, falar-Ihes de acordo com o entendimento humano, revelar-se de acordo com as aptidões humanas. Ela é ao mesmo tempo religião, conhecimento, ciência natural, iniciação à arte, história, divertimento e recreação, uma vez que todo pormenor sempre nos permite remontar à Unidade primordial. 
Fundada na iniciação e na experiência, a tradição oral conduz o homem à sua totalidade e, em virtude disso, pode-se dizer que contribuiu para criar um tipo de homem particular, para esculpir a alma africana.

Uma vez que se liga ao comportamento cotidiano do homem e da comunidade, a "cultura" africana não é, portanto, algo abstrato que possa ser isolado da vida. Ela envolve uma visão particular do mundo, ou melhor dizendo, uma presença particular do mundo - um mundo concebido como um Todo onde todas as coisas se religam e interagem. A tradição oral baseia-se em uma certa concepção do homem, do seu lugar e do seu papel no seio do universo. Para situá-la melhor no contexto global, antes de estuda-la em seus vários aspectos devemos, portanto, retomar ao próprio mistério da criação do homem e da instauração primordial da Palavra: o mistério tal como ela o revela e do qual emana. ${ }^{42}$

No conto "Carne de Língua" eu posso fazer várias leituras ao considerar o estado da rainha doente. Posso associá-lo à cultura escolar na qual estava inserida, ao reconhecer a necessidade de abertura às possibilidades oferecidas pelo imaginário, em nosso cotidiano. Posso também associá-lo, através das considerações de Amadou Hampaté Bá, ao compará-lo à nossa cultura ocidental de maneira mais ampliada, e ainda numa dimensão mais particular, ao meu próprio estado pessoal.

Outro momento significativo compartilhado na última reunião pedagógica que organizei em 2015 foi a confecção das bonecas Abayomi, contando com a participação de duas professoras que realizaram a oficina.

Fiquei muito satisfeita em poder proporcionar que o grupo de educadores confeccionassem suas bonecas. Nesta reunião contei com a presença de todos os segmentos da escola. As bonecas Abayomi em sua origem eram confeccionadas usando apenas retalhos de tecidos pelas mães escravas para suas filhas: eram o melhor que poderiam oferecer de si para suas crianças. Foi um momento muito agradável compartilhado por todos e percebia a força simbólica evocada pelas bonecas.

Meu objetivo com a vivência além de compartilhar uma experiência lúdica agradável e rica em sensibilidade era o de repertoriar as professoras para que também confeccionassem as bonequinhas com as crianças.

E após a realização desta oficina deixei sobre minha mesa de trabalho algumas destas bonecas.

\footnotetext{
${ }^{42}$ Hampate-Ba, 2010, p.201.
} 
Além de sua ludicidade e beleza, minha intuição dizia que estas bonecas significavam algo maior: elas simbolizavam uma força geradora, uma voz arquetípica, um desejo de criação e fecundação do novo.

Desta vez, a sala foi ornamentada não por uma escultura comprada, mas por bonecas confeccionadas por malhas, tintas e tecidos transformados pelas mãos dos educadores da escola. Tanto a escultura quanto as bonecas traziam a força da Grande Mãe. Mas os processos formativos compartilhados estavam ali representados pela produção poética das mãos. Além dos projetos de leitura, brincadeira e musicalização também estava investindo nestas sementes sugeridas pelas próprias professoras, no caso o projeto de plantio de flores e hortaliças na escola e a confecção das bonecas Abayomi.

Pesquisando a origem destas bonecas, descobri que para acalentar seus filhos durante as terríveis viagens a bordo dos tumbeiros - navio de pequeno porte que realizava o transporte de escravos entre África e Brasil - as mães africanas rasgavam retalhos de suas saias e a partir deles criavam pequenas bonecas, feitas de tranças ou nós, que serviam como amuleto de proteção. As bonecas, símbolo de resistência, ficaram conhecidas como Abayomi, termo que significa "encontro precioso", em lorubá (abay, quer dizer, encontro; e omi, precioso), uma das maiores etnias do continente africano cuja população habita parte da Nigéria, Benin, Togo e Costa do Marfim. Sem costura alguma (apenas nós ou tranças), as bonecas não possuem demarcação de olho, nariz nem boca, o que favorece o reconhecimento das múltiplas etnias africanas.

Refleti sobre a emergência do feminino. Quando você dá uma boneca Abayomi para alguém, esse gesto significa que você está oferecendo o que você tem de melhor para essa pessoa. Provável encontro precioso com a Grande Deusa, num espaço formado majoritariamente por mulheres. $O$ encontro de vozes femininas.

O segundo semestre de 2015 estava efervescendo em meio a muitas ações, atendimentos, entendimentos e conflitos.

A função de coordenar o pedagógico é extremamente multifacetada, repleta de elementos afetivos. Ao mesmo tempo, conseguia reconhecer o fruto do meu trabalho também me sentia muito cansada, como se minha fonte estivesse secando. Precisava cuidar de minhas raízes para que minha seiva voltasse a fecundar novas sementes. Percebia-me exausta pelas manhãs. 0 fato de também trabalhar no período noturno como professora universitária, justificava em parte, aquele grande cansaço. Mas sempre me retroalimentei desta rotina que mistura a 
formação inicial de professores na graduação de Pedagogia e a formação em serviço na escola. Afinal, vinha tendo esta rotina ao longo dos últimos seis anos desde 2010.

Mas sentia um processo de transformação interior mais intenso dialogando com a minha atuação profissional. Talvez não estivesse sentindo pertencimento ou reconhecimento. Talvez estivesse chegando à famosa crise da meia idade.

O fato é que passei a ter fortes dores de cabeça e meus analgésicos já não tinham efeito sobre as dores que se espalharam pelo meu corpo, especialmente, na região do meu pescoço, ombros, irradiando-se e tornando-se insuportável.

E assim, uma semana antes de meu aniversário, fui internada. E ali estando em contato com meu silêncio, lembrei-me em espiral de vários momentos em que sobrevivi ao minotauro da solidão, para com ele me reencontrar ali, naquele novo desafio, um novo capítulo do labirinto. Minhas experiências profissionais atuando como formadora trouxeram as tramas e os fios com os quais passei a recuperar o sentido do todo. Ao tecer a presente narrativa sou movida pelos mitos, arquétipos e imagens, nem sempre explícitos, mas por este motivo, ainda mais marcantes.

Iniciei meu relatório de qualificação "escrevivendo"43 Poiésis: A imagem da Dançarina Flamenca que hipnotizava com sua saia vermelha a força do Grande Touro. Ali explorei esta relação entre imagem e palavra, corpo e alma, razão e imaginação.

Ao escrever minha narrativa autobiográfica, percebi os fortes lampejos do símbolo que me guiavam pela jornada. Passei a reconhecer a simbiótica relação entre corporeidade e imaginação.

O corpo sempre esteve aqui. Mas minha compreensão acerca de sua relação com a minha alma ficou muito mais evidente a partir dos últimos anos.

Provavelmente, minha entrada na quarta década de minha vida esteja visceralmente ligada a isso. Meu corpo a cada dia grita mais alto. A corporeidade mostra na escultura viva de minhas formas outras nuances de minha alma.

Algumas limitações começaram a ressoar na expressão de meu cansaço, nas dores do corpo... Nas enfermidades que começaram a acordar ao debilitarem meu sistema imunológico.

Crises sucessivas de sinusite e alergia. Dores em minhas articulações, frequentes enxaquecas, dores espalhadas pelo corpo... ou seriam dores da alma?

Foi assim que em setembro de 2015 , fui internada pela primeira vez em minha vida. Setembro mês em que nasci. Mês da primavera, na qual sementes se abrem em flor, anunciando a vida

\footnotetext{
${ }^{43}$ Willms, 2013.
} 
perseverante, perfumada, sensual e colorida que viceja entre os vales, que encantam pássaros, que alimentam a continuidade da criação, sendo ela própria: a criação.

Uma crise de hérnia de disco na região cervical foi a responsável por uma pausa. Fui obrigada a parar. Estando internada e sob efeito de forte medicação para dor, passei a reconhecer a necessidade de ser cuidada. Percebi que o que me paralizara por um instante poderia ser também o elemento disparador para a retomada do movimento: $\mathrm{A}$ busca pela cura... $\mathrm{A}$ tensão dos músculos estava comprimindo minhas vértebras e estas a medula. Invólucro da kundalini, como simbolicamente poderíamos associar o locus da energia vital, por onde reverberamos, ressoamos, produzimo-nos.

Na Narrativa do Si-Mesmo, ouvindo o grito do corpo ressoou a alma... Estava precisando de cuidados. "Meu reino talvez estivesse devastado" tanto quanto no conto africano "Carne de Língua", precisando de novas histórias para voltar a florescer. Novas danças para corporar e incorporar.

Ao reviver este momento, pela memória, a narrativa que escrevo é que me escreve. Palavra corporificada que dá voz ao imaginário. Imaginário que me produz dialogando com meu entorno, em comunhão com os partícipes da jornada.

Ressignificar a experiência de meu próprio corpo, lendo suas marcas em ressonância com as imagens dele evocadas, permitiu-me concordar com os estudos de Keleman, legitimando-o, pela reflexão gerada ao produzir a presente narrativa autobiográfica.

No livro Mito e Corpo, Stanley Keleman cita Joseph Campbell e na sequência expressa sua tese descrita a seguir:

Durante quatorze anos, Joseph Campbell e eu realizamos seminários anuais sobre o tema mito e corpo. E, naquela ocasião, ele fez uma afirmação que continua sendo a viga do nosso relacionamento e a base deste livro: a mitologia é uma canção, é a canção da imaginação inspirada pela energia do corpo.

Para mim, mitologia é a poética do corpo cantando a nossa verdade celular. O mito é um poema sobre a experiência de ser corporificado e sobre a nossa jornada somática. É a canção da criação, experiência genética que organizou um jeito de cantar, dançar, pintar, contar histórias, que transmitem essa experiência aos outros.

Nessa aventura, Joseph Campbell e eu fomos irmãos, a química entre nós foi imediata. Eu era o idealista prático; ele o trovador idealista. O meu método somático-emocional fundamentou o seu conhecimento do literário e da imaginação no corpo. Sua compreensão da visão ancestral mudou minha perspectiva somática e aprofundou minha compreensão da nossa realidade interna, somática. 
Joseph Campbell sabia que a experiência é conhecimento e que o conhecimento acadêmico não era a experiência que as pessoas buscavam. Sei que a experiência é um evento corporificado e o mito, como um processo organizador, é um modo de criar ordem a partir da experiência somática.

O uso da Prática do Corpar, em que intensificamos e, então, desorganizamos nossas posturas emocionais, gerando sentimentos e evocando lembranças, o intrigava. Esses exercícios fazem emergir o corpo desconhecido, sob a forma de imagens, sonhos e expressão emocional. Eles dão vitalidade ao sentido de si corporal ${ }^{44}$.

Já havia relatado nesta narrativa, desde sua fase de qualificação, acerca da experiência de dar voz à imagem a partir do corpo em movimento. Durante um treino aeróbio ao caminhar, exercitando meu corpo na academia, movida pela musicalidade rítmica entrei num estado de êxtase ao imaginar a dançarina flamenca que hipnotizava o touro com a dança de sua saia vermelha.

A profundidade daquela imagem foi atualizada, posteriormente, quando tive a oportunidade ao vivenciar novas experiências a partir da internação e de conhecer as contribuições de Sérgio Lima na obra "O Corpo Significa" (1976) quando ao tratar da simbologia das imagens sinaliza que:

Os homens do paleolítico viviam numa cultura de caçadores. A deusa da fertilidade regia o culto e dispunha os princípios de sua teologia. (...) uma deusa matriarcal (sua figura) não era estética, mas, por (causa da forma de) seu corpo conter o poder de reproduzir as espécies, as quais estavam constantemente em perigo, algo inerente ao seu poder assegurava a sobrevivência. Muito pouco na arte paleolítica pode ser atribuído às mulheres como provedoras de prazer físico. Para os nossos ancestrais de vida curta, que produziam a arte das grutas, sobrevivência era primordial. E se bem que o macho fosse mais forte fisicamente, ele não continha poder psicológico por esse motivo. A deusa não existia para ser amada pelos membros de seu culto, mas para ser prenhada por eles. Ela possuía o poder de nutrir e restaurar ou de abandonar e destruir.

[...] Um tema conectando mulher e bisão percorre toda a arte parietal. Bisão e mulher são relacionados e ligados porque uma conexão entre eles foi percebida pelo homem do paleolítico (...) a deusa matriarcal nas raízes de nossa tradição, a mãe-terra do palácio de Knossos (mitologia cretense) cujo caráter de mãe-natura está revelado por sua vestimenta ritual, a qual deixa os seus seios expostos. Seu culto data do período paleolítico, como

\footnotetext{
${ }^{44}$ Keleman, 2001, p. 17 e 18.
} 
atestam os elementos de peles animais usados nos seus rituais. Ela segura o machado duplo, ou 'labrys', em ambas as mãos. O 'labrys', originariamente uma faca de pedra, era usado apenas por mulheres e servia para a castração, primeiro em humanos e, mais tarde, em animais selecionados por estarem carregados de qualidades humanas. Esse instrumento sagrado e sacrificial, juntamente com os chifres do touro, era um símbolo central nos altares cretenses (área de cultos Creto Egeu). No culto de fertilidade de Creta, o touro simbolizava o filho-amante, que existia para servir à deusa. Servitude masculina para com o poder matriarcal era ligado no íntimo da função-raiz de nossa própria tradição. (...) 0 poder é estendido à deusa não em gratitude, mas para assegurar algo essencial ao grupo como um todo. A fêmea num contexto matriarcal tende a saber quem ela é, porque ela é isso, e o que fazer com esse poder. Seu corpo garante sobrevivência, assim Ihe é dado o encargo da continuidade da espécie ${ }^{45}$.

Identificada com a experiência corporal da internação, escrevi a Sede do Corpo que se sucedeu à Fome da Alma, e que recupera no movimento espiral do imaginário os mitos que desenham a jornada. Indo do reino devastado à possibilidade de sua regeneração.

\footnotetext{
${ }^{45}$ Lima, 1976 p.22 a 25.
} 


\section{A Imagem Labiríntica: Vertigem, Voragem e Vórtice}

Era Ariadne?

O que me chamava para o Labirinto?

Seria a pulsão de Mnemosina?

Voz de um tempo vivido,

Coberta pelo eco em espiral

Sua vibração em ressonância

Com a dança das musas

Deusas tecelãs para além do tempo e do espaço

A dança do fio da vida

Vida fluida e verdejante

No verso, na carne e no espírito

Brilho e penumbra

Sopro de respiração

Que se deita e se levanta

Serpenteia na rítmica pulsante da criação

Era verbo, era imagem

Inspiração e expiração

Em sua expressão incessante

Na busca pela vida

Núcleo celular

Que se condensa e expande

Nota musical

Que anuncia

Constelações Infinitas

De novas estrelas

Que surgem em outras auroras

Auroras gélidas e quentes

Úmidas dos fluídos que correm nas veias da terra primordial

Para além dos tempos

Raízes ancoradas no desejo

De uma árvore ancestral

A condição humana

Presença afrontada e revelada

O ser que ressoa em cada manhã

E se refaz em cada crepúsculo

No beijo entre a luz e a sombra

Na flor da pele e no toque suave da pena teclada

Carne e espírito

Alma que se perlabora

Prósopon em vários tempos

Forjado na ambiência

Na experiência que lhe transcende

Entre o humano e o sagrado

Nem Ícaro

Nem Minotauro

Nem Dioniso

Nem Teseu

Nem Ariadne

Nem Fenix 
Nem Penélope

Nem Ulisses

Nem Perséfone

Nem Deméter

Nem Ártemis

Nem Atena

Nem Afrodite...

Mas do instante que nos escapa

E que nos funde

À Impermanência do que somos

Como pessoas.

A história que se constrói

Na criação do cotidiano

Na experiência entre imagens e ações

Pelas pulsões...

Entre o grito e o silêncio

Toda música de nossas mãos, nos rastros de nossos pés

A criação

Daqueles que antes de nós

Deixaram suas marcas

Na carne da terra

Para os futuros acordes dos versos serem gerados

Mãos que espalham novas sementes

Lançadas em novas espirais

Não mais presas

No labirinto

Mas germinadas na flor beijada pelo vento

Que com a maré

Transforma em ondas

A força lunar

Seria Poseidon?

Seria Afrodite?

Seria Eros?

Das espumas nasce o neóteno

Teria sido trazido por Hermes?

Pelas ondas dionisíacas

Que reconciliam o uno ao múltiplo

Unitas multiplex

A força do todo

Em cada um

Circularidade na forma de espiral

Na rítmica incessante

Da sístole e da diástole

Ondas centrífugas e centrípetas

Que alimentam o ovo primordial

Em suas repetições

Criação continuada

Fluxo e refluxo

Morte e renascimento

Da obra e de seu criador

Pelas explosões e implosões

Aberturas e fechamentos

Eis o fio 
Esta outra poesia, "A Imagem Labiríntica: Vertigem, Voragem e Vórtice", foi escrita no calor de minhas releituras, ao iniciar o exercício de memorial como parte integrante do relatório de qualificação no doutorado e que depois se tornou o principal viés da investigação autobiográfica. Busquei minhas referências bibliográficas, mas muito mais do que isso, o fio que poderia me orientar neste árduo processo de registro e estudo do imaginário na formação de educadores: a narrativa de si.

A imagem do labirinto retoma minha dissertação de mestrado: "Trilhando pelo Labirinto: Uma Incursão Antropológica à Latência de uma Escola Municipal"46.

Decidi iniciar esta nova etapa, não necessariamente, relembrando de forma detalhada o trabalho realizado no mestrado, mas permitindo que as imagens trazidas pela memória, ocupassem sua própria configuração, de acordo com sua ressonância. Reverberou no eco do tempo, a imagem de uma pedagoga recém-formada pela Faculdade de Educação da USP que também se encontrava no início de sua carreira como professora e gestora na rede municipal de São Paulo. Perguntei-me sobre quem era naquele momento e sobre quem me tornei, após tantos anos e quais seriam minhas motivações ao retomar minha vida acadêmica no doutorado.

Em 2002, quando defendi meu mestrado, estava vivendo mudanças profundas em minha vida. Além da intensidade do trabalho de sistematização da dissertação, era professora regente numa turma de terceira série no ensino fundamental na escola campo de pesquisa. Também havia iniciado minha carreira acessando outro cargo na rede municipal de São Paulo como coordenadora pedagógica numa outra escola municipal de ensino fundamental.

No campo pessoal, também passava por grandes desafios. Em março de 2000 com o falecimento de minha mãe, vivi o drama de Perséfone às avessas. Desci aos ínferos com a perda de minha mãe. Foi Deméter minha mãe provedora quem desaparecera. E conheci o Hades.

Embora houvesse dedicado o trabalho de mestrado à minha mãe, não havia detalhado o impacto dessa perda em minha jornada. Tentei dar continuidade aos projetos com os quais já havia me comprometido, procurando as referências herdadas de minhas inúmeras conversas

\footnotetext{
${ }^{46}$ Fonseca, 2002.
} 
com minha mãe. Uma destas orientações era a de que me tornasse uma mulher independente. Que continuasse sempre estudando para alcançar novos degraus na profissão.

Minha mãe era cardíaca e na noite de 30 de março de 2000, falecera de um infarto fulminante, sendo eu uma das últimas pessoas com quem esteve em vida. Um oceano se ergueu sobre mim. Sonhava com ondas gigantes que me engoliam. Sonhava inúmeros pesadelos que expressavam o pânico gerado pela ausência.

Ainda naquele ano, em agosto, vinha acompanhar meu pai na superação de um grande problema de saúde, do qual saiu vitorioso, para nossa extrema felicidade.

Na ocasião, como anunciei, anteriormente, tinha começado a acumular cargos na prefeitura de São Paulo. Era professora efetiva em duas turmas. Pretendia me casar em dezembro daquele ano, o que acabou acontecendo em fevereiro do ano seguinte, dez dias após apresentar minha qualificação do mestrado.

Foram momentos intensos, mudanças importantes em minha vida. Desafios superados com muita perseverança e o apoio de pessoas marcantes, como o de minha professora orientadora Maria do Rosário Silveira Porto.

Em 2001, tinha uma rotina de trabalho intensa e estava me adaptando à vida de casada. $\mathrm{Na}$ época, contava com o apoio do meu marido. Tínhamos uma relação de grande cumplicidade. E de certa maneira, o incentivei a iniciar sua própria carreira como professor na rede pública municipal.

A imagem do labirinto no mestrado foi explorada na perspectiva da pesquisa sobre a escolacampo, na qual, como metáfora, representava a não linearidade, a assimetria, a imprevisibilidade e a duplicidade.

Duplicidade expressa pela dupla viagem: pois se, procurarmos a saída do labirinto para além de nós mesmos, também somos levados ao nosso próprio interior. Assim, a ida e a volta no labirinto, seria o símbolo da morte e da ressurreição espiritual. Entrar no labirinto, imergir em si mesmo para voltar transformado.

Nenhuma outra imagem poderia evidenciar tão bem, o sentimento que vivia. De estar perdida, buscando o fio que poderia me salvar do confronto com o minotauro. Ou que me capacitaria para enfrentá-lo. O fato é que em nenhum momento da dissertação, explicitei esta evidência, dando vasão à minha dor. Dar visibilidade à dor a partir da morte de minha mãe e ao meu renascimento em meio a tantas transformações seria olhar para o espelho. 
Talvez por isso, ou por outras razões que somente o mito nos possa revelar, decidi iniciar o memorial com esta imagem. Mas não pretendo explicá-la, apenas contemplá-la ouvindo os gritos de minha garganta. Lembrando a epígrafe de Merleau-Ponty:

"O grito e a voz terminam em sons e eu os ouço. Como o cristal, o metal e muitas outras substâncias. Sou um ser sonoro, mas a minha vibração, essa é de dentro que a ouço, como disse Malraux: Ouço-me com minha garganta" ${ }^{\prime 47}$.

Ferreira-Santos 48 ao comentar esta epígrafe ressalta que o "ouvir-me com minha garganta assinala esta recíproca implicação do produtor e do produzido na vibração íntima das ressonâncias".

Daí as imagens revelarem mais de mim que meu discurso racionalizado.

No distanciamento do tempo o fio do labirinto em movimento tornou-se uma espiral. As linhas retas, ora conexas outras desconexas do labirinto, trouxeram novas perguntas, novas motivações, novos contornos.

Nas palavras de Chevalier e Gheerbrant ${ }^{49}$ :

O labirinto seria uma combinação de dois motivos: o da espiral e o da trança, e exprimiria uma vontade muito evidente de representar o infinito sob dois aspectos de que ele se reveste na imaginação do homem, isto é, o infinito eternamente em mutação da espiral, que pelo menos teoricamente, pode ser pensada como sem fim, e o infinito do eterno retorno figurado pela trança. Quanto mais difícil a viagem, quanto mais numerosos e árduos os obstáculos mais o adepto se transforma e, no curso desta iniciação itinerante, adquire um novo ser.

Além do labirinto outras imagens foram evocadas a partir das duas poesias anunciando o retorno.

Após tantos anos, sem narrar o percurso, reconheço-me novamente como uma sintaxe de metáforas...

Provavelmente, por isso, que a poesia tenha precedido a narrativa.

Afinal, por onde pretendia recomeçar, após dez anos?

Quais minhas motivações para o retorno ao doutorado? Como recuperar o fio da narrativa?

Então, optei em explorar a imagem do labirinto, sentindo seus ecos para além do tempo.

\footnotetext{
47 Merleau-Ponty, 1992.

48 2000, p. 64.

${ }^{49}$ 1999, p.532
} 
Quando a imagem particular assume um valor cósmico, produz o efeito de um pensamento vertiginoso. Uma tal imagem-pensamento, um tal pensamento-imagem não tem necessidade de contexto... É preciso que as pessoas racionais perdoem àqueles que escutam os demônios do tinteiro ${ }^{50}$.

Talvez tenha sido os demônios do tinteiro que me convidaram para dar continuidade à saga da investigação, olhando para minha história de vida em seus diferentes aspectos como aquele que busca interpretar sua própria jornada, extraindo dela a seiva dos sentidos.

Escutar os demônios do tinteiro: escutar o ritmo de seu tempo e ver o espaço imagético produzido por sua tinta. O controle visual se obumbra. A flauta seduz o ouvido. O tambor percute a pulsação uterina. Martelo, bigorna, tímpano servem agora a um outro ferreiro alquímico sonoro. Martelam imagens de uma outra dimensão ${ }^{51}$.

Labirinto, espiral, sementes, plasma, carne, sopro, crepúsculo, neóteno, aurora, eterno retorno, pulsão, vozes ancestrais e ressonância. Palavras que ao serem repetidas nas poesias, revelam a própria obra. São as palavras-imagens que me revelam ao escrevê-las.

Merleau-Ponty já nos advertia muito bem: É certo que a vida não explica a obra, porém certo é também que se comunicam. A verdade é que esta obra a fazer exigia esta vida. A obra exige esta vida. Somos portadores de uma obra a realizar-se ${ }^{52}$.

Estudar meu percurso como uma mulher que trabalha desde os doze anos de idade na área da educação, surgiu como um tema de vida, um revolver a terra em busca da mulher oculta que impulsiona sua essência em busca da vida, nutrindo-se nas águas de sua história, tecendo como Ariadne os fios de seu destino ao desafiar-se, gestar-se, formar-se, humanizar-se para renascer num novo ciclo de vida.

Surgiu assim o desafio do Doutorado em minha jornada. Para além de um título o que me motivou a perseverar nesta jornada foi a busca do sentido. O diálogo com minhas vozes interiores, o ouvir o eco subterrâneo de meus ancestrais, as cantigas reverberantes da infância em ressonância com a mulher que me tornei. As vozes de meus mestres, as palavras errantes dos poetas que me animam, as narrativas das crianças, as brincadeiras desde o quintal...

\footnotetext{
${ }^{50}$ Bachelard, 1989, p.33

${ }^{51}$ Ferreira-Santos, 2000, p.61

${ }^{52}$ Ferreira-Santos, 2000, p.60
} 
O brincar de escolinha, o fazer de conta de ser tantas possibilidades. Neste diálogo de Mnemosina e Ariadne, a memória evoca o fio da narrativa que me conduz pela vida.

O que uma mulher, filha de um lar modesto da zona sul de São Paulo, estudante da escola pública que se tornou coordenadora pedagógica e formadora na rede municipal da cidade de São Paulo estaria buscando "nos bancos" da universidade novamente, após vivenciar tantos ciclos de morte e renascimento em sua vida?

Teria eu escutado os demônios do tinteiro? Pesquisando os processos formativos a partir da minha própria experiência, estaria buscando religar o fio da habilidosa tecelã Ariadne para encontrar um novo sentido?

Estaria buscando a reconciliação das fases desconexas ao fio harmonizador da minha alma?

Este turbilhão de imagens e memórias narradas até aqui expressam a vertigem, a voragem e o vórtice de uma experiência de narrar como catarse mitopoiética. Uma experiência que se faz numinosa. A respeito da vertigem, da voragem e do vórtice orienta-nos:

Se nos recordarmos das estruturas antropológicas do Imaginário em Durand (1981) e da inscrição da imagem na corporeidade presente na noção de trajeto antropológico, podemos inferir que o primeiro constituinte da experiência numinosa neste exercício de compreensão fenomenológica será, justamente, a vertigem: perder o controle visual e postural centrado na ascensão, característicos da estrutura de sensibilidade heróica. Vigilante constante, guerreiro solar portador da espada e do cetro monárquico: aquele que domina exatamente pelo controle do espaço através do poder da visão. Então pela vertigem, a visão se obumbra, o corpo se enreda no espaço e no tempo circulares. A percepção se desfoca; portanto, a própria consciência se altera para um outro estado. Esta vertigem está espelhada na superfície aquosa do movimento contínuo de fluxo e refluxo, morte $e$ renascimento. (...) Uma vez a consciência obumbrada pela vertigem, a obra musical e/ou literária vora o ouvinte/partícipe/leitor que, por sua vez, alimenta-se da mesma experiência. (...) Na literatura, a voragem opera o tráfego e tráfico de sentidos e significados que vão da obra ao ouvinte/partícipe/leitor e vice-versa, até o ponto em que já não distingue o centro irradiador. A periferia se dilui e o centro está por toda a parte. Permanece a pulsação em sístole/diástole da experiência vorática. (...) Mergulhando em profundidade na experiência estética da música e da literatura em sua dimensão sagrada, aproximamo-nos do centro da experiência que é o que denominamos vórtice $e^{53}$.

\footnotetext{
${ }^{53}$ Ferreira-Santos, 2000, p.62-5
} 
Na narrativa, através da memória tive a oportunidade de rever momentos da minha vida, de repetir imagens, sentimentos e pensamentos para recriá-los, dando um novo sentido para a saga. Reconhecer que os eventos da história aconteceram da maneira necessária para chegar até aqui. Aceitar o trágico da vida é uma experiência de religação com o sagrado cotejando seu vórtice. Uma experiência de entrega e de recriação continuada.

É criar novamente, dar vida novamente à obra, é parir filhos que nos dão luz a nós mesmos, num ato increador ${ }^{54}$.

A narrativa pessoal se comparada à narrativa mítica traz sua própria rítmica. Imagens que retornam. Revelam sua repetitividade.

Para Ferreira-Santos, com relação ao sagrado vivenciado na experiência estética da música e da literatura, é possível afirmar que:

Cabe-nos, agora, apontar uma outra característica que nos prepara para a experiência numinosa da obra: sua repetitividade. A redundância, a recorrência, a ressonância da narrativa mítica já foram tratadas por vários pesquisadores e são as bases materiais do trabalho hermenêutico mitanalítico. Mas vale a pena reafirmar: $O$ mundo da repetição é o mundo da criação continuada. A repetição assegura a reintegração do tempo humano no interior do tempo primordial ${ }^{55}$.

As metáforas da poética constituem o fio da narrativa que ao se repetirem trazem sua cadência própria. Da vertigem inicial, as imagens voram, "devoram" cada nova linha que se escreve até chegar ao coração da experiência, o vórtice.

Pesquisando Ariadne, a senhora do labirinto, a partir da contribuição de Chris Downing ${ }^{56}$, me surpreendi com as semelhanças da narrativa da autora e da minha própria.

À medida que a autora relatava sua experiência mítica cheguei a me emocionar com o número de identificações de nossas jornadas. As ressonâncias geradas remeteram-me a uma experiência vertiginosa e vorática que, por sua vez, prepararam o contato com o vórtice.

A partir daqui, escolhi cruzar trechos da narrativa de Downing com a minha autobiografia, naquilo que Ferreira-Santos \& Almeida definiria como jornada interpretativa ${ }^{57}$ :

Não dizemos aqui de uma técnica de interpretação que possa ser utilizada de maneira instrumental, sem nenhum comprometimento ontológico. Ela é uma empreitada onde,

\footnotetext{
54 Berdyaev, 1957, p. 98.

55 2000, p.61

56 1992, p.157

${ }^{57}$ Ferreira-Santos \& Almeida, 2012, p. 43
} 
seguindo aquela sugestão de Paul Ricoeur (articular o olhar do geógrafo, o espírito do viajante e a criação do romancista), saio de meu lugar tranquilo e deixo meus pré-conceitos e pré-juízos (a epoché fenomenológica) e vou buscando o sentido (tarefa hermenêutica) nessas obras da cultura e da arte. Mas, curiosamente, essa jornada interpretativa (que leva para fora) também me remete para o mais específico, para o mais interior das minhas descobertas. Paradoxalmente, no mais estranho, no mais exótico, no mais distante... eu me reencontro. É a temática exposta por Heidegger no círculo hermenêutico: ao buscar o sentido nas coisas percebemos que somos nós que, reciprocamente, atribuímos sentidos às coisas. Não são aspectos somente antagônicos, mas, sobretudo, complementares da jornada interpretativa. O dilema passa a ser não, propriamente, como entrar no círculo hermenêutico, mas como sair dele. De nosso ponto de vista, a forma privilegiada de sair do círculo hermenêutico, na troca incessante de sentidos (no momento poiético do círculo), é a percepção do Outro em seu tempo próprio e o impulso criador que nos toca: somos impelidos a $\mathrm{criar}^{58}$.

Downing ${ }^{59}$ realiza um exercício autobiográfico, faz uma descrição do seu caminho tortuoso em direção ao centro do labirinto. Relata ter reconhecido aproximações do mito de Ariadne em sua vida, sem que houvesse uma escolha consciente. Especialmente, ao descrever um relacionamento pessoal no qual fora abandonada.

Em suas palavras revela:

Entretanto, acabei reconhecendo que o abandono de Ariadne por Teseu é o prelúdio necessário para o seu relacionamento com Dioniso. Se Ariadne ajuda Teseu, então ela precisa ser abandonada. Isso pode parecer estranho num primeiro momento, mas é absolutamente essencial para a compreensão desse mito. Na parte da história de Ariadne/Teseu, Ariadne é uma figura da anima (embora, naturalmente, muito diferente da de Perséfone: Ariadne obviamente tem mais iniciativa, razão pela qual ela tem de ser abandonada em vez de raptada). O que essa história quer nos dizer aqui é que a dependência da anima precisa ser superada: Teseu não pode ficar com Ariadne. Mas também é importante para Ariadne ser abandonada, de modo que ela possa abandonar sua dependência em representar o papel de anima.

Em 2009, após sete anos de casamento e quinze de relacionamento, passei pela experiência do divórcio. Em termos simbólicos, identifiquei esta aproximação da minha narrativa pessoal com

\footnotetext{
${ }^{58} 2012$, p. 43

59 1992, p. 162
} 
o mito de Ariadne ${ }^{60}$. Tal como Downing após alguns anos de afastamento da situação, eu pude reconhecer que foi somente a separação, que tornou possível desenvolver aspectos da minha personalidade que me transformaram em quem sou hoje.

O processo de tomada de consciência desta transformação aconteceu de forma gradual e dolorosa até chegar a tentar desfrutar do estado de bem-aventurança em que momentaneamente me encontro, quando tento ter gratidão por todos os eventos que me aconteceram: traição, abandono, dificuldades financeiras e preconceito.

Tenho a conviç̧ão de que só vou conseguindo superar cada uma destas situações pela perseverança e a presença do sagrado na minha vida.

Todo o processo de superação também contou com a importância do trabalho em minha vida. Em 2010, para me reorganizar após o divórcio, voltei a ter um segundo vínculo empregatício. Iniciei minha carreira como professora no ensino superior num curso de Pedagogia de uma Universidade em Santo Amaro.

Neste mesmo período, voltei a atuar como formadora de educadores na Divisão de Orientação Técnico-Pedagógica na Diretoria Regional de Educação de Campo Limpo. Foi um período de novas mudanças e muitas aprendizagens.

Estas duas atuações profissionais revestiram minha vida de significado, pois em ambas, poderia trabalhar com a formação de educadores.

Para Downing:

A ligação particular de Ariadne com a morte está naturalmente representada de forma preeminente pelo labirinto, do qual a maioria jamais retorna, mas de onde alguns voltam transformados. (...) Isso nos traz de volta aonde começamos. Kerényi diz que Ariadne representa "a realidade arquetípica do outorgador da alma, do que faz de uma criatura viva uma pessoa. Desse modo, no centro do labirinto, chegamos ao ponto em que se volta para o início. O caminho sinuoso, relembrando as palavras de Eliot, leva-nos de volta ao lugar onde começamos, e o reconhecemos pela primeira vez. Encontramo-nos assim agora como começamos, com Ariadne como anima, Ariadne como alma. (...)Todavia, isso é assim num jeito de ser muitíssimo mais profundo. Ariadne, não mais a anima que aguarda fora do labirinto enquanto outrem entra, significa a alma como aquilo que está dentro do labirinto, o centro do eu, o que eu chamo de Ela, como James Hilman tentou expressar, a anima em seus níveis mais expressivos, nada tem que ver com a contra-sexualidade. Nem mulher magicamente atraente, sedutora, fascinante, nem um lado feminino do homem - a anima é a alma, com a qual as mulheres precisam associar-se tão verdadeiramente quanto com os

\footnotetext{
${ }^{60}$ Veja-se também Rubira, 2015; aprofundando as relações estabelecidas por Chris Downing.
} 
homens. A anima é "o que dá aos acontecimentos a dimensão de alma", o que nos harmoniza com o significado imaginal das experiências de que participamos ${ }^{61}$.

Ciclos de morte e renascimento. Inverno e primavera. Surge a borboleta, voa a Fênix. Narrando minha história fui dando voz ao mito. Recorrendo à metáfora e à memória como forma de regeneração e de hermenêutica, que se revela como uma jornada interpretativa, na qual a pessoa é o início, o meio e o fim de seu próprio engajamento existencial. Não se trata de buscar correspondências entre o mito e a realidade, mas fazer um esforço interpretativo que permita dar voz à nossa polifônica alma. Não se trata de apontar um mito como chave do labirinto, mas atentar para a existência de um complexo jogo de espelhos, para assim, aprofundar nossa interpretação sobre a jornada. Portanto, longe de explicar, o que pretendo é: alargar a razão e profundizar a sensibilidade.

Inicio após a vertigem, vorada pela imagem até chegar ao coração da experiência. Eis a investigação autobiográfica no nível do doutorado: um chamado à aventura... Uma reconstituição das peças do mosaico da vida, uma tessitura dos retalhos de cada uma das cenas recobertas pelo tempo... 


\section{A Fome da Alma}

Gira em espiral

Pulsa, expande, condensa

Densa e flutuante

Expande, condensa

Vibra num movimento de sistole e diástole

Alimenta a existência

Pela poética do encontro

Tum, tá, tum, tá, pulsando pela vida

De tutti cordi

Bate um coração

A espiral em seu movimento

Levada pelo vento

Germina a semente do sonho

Sonho que se plasma no verbo que se faz carne

Pela cadência da imagem

Reverbera o sopro da VIDA

No devir das impressões

Ecoa o ancestral que me habita

E pelo amor fati ao meu caminho

Agradeço à fome de minha alma

Pelo desejo que me traspassa

Pela busca do sentido

Agradeço ao nômade renascido

No mais ardente crepúsculo

Num novo tempo, em outro espaço, em outra pele...

Reverbera a nova carne em novos acordes...

Bate o tambor em notas eletrônicas

Traçando um trajeto antropológico

De uma crepuscularidade ancestral

De um amanhecer mítico

Após um entardecer pedagógico

Pelas veias da poesia

O corpo grita

$O$ homo symbolicus, o ser selvagem

Que beija a Lua

Encharca-se do Sagrado

E desperta numa aurora úmida e aconchegante

$\mathrm{Na}$ coincidentia oppositorum

De um breve instante

Tudo muda

Mutatis-mutandis no contínuo movimento da espiral

Anuncia-se o eterno retorno

Negando a entropia

Pulsando pela poièsis

Por uma educação de sensibilidade

Na qual o herói que emerge

Imerge e reencontra sua pertença, humaniza-se

Em cada novo sulco 
Das linhas de sua face

Torna-se o que é...

Foi chamado pela aventura

Como sujeito da experiência que se expõe ao risco

Atravessando o desconhecido

No encalço de sua bem aventurança

Novas espirais...

No princípio era o verbo?

No princípio era o corpo?

No princípio era a imagem?

Pulsão entre caos e cosmos.

Pulsão gerada entre Eros e Tanathus.

Luz, sombra, silêncio e ruído...

Animus e Anima

Num casamento sagrado...

o Feminino e o masculino fecundam...

$O$ "tertium datum", a tríade...

$O$ encontro sagrado entre o dia e a noite

Gera um movimento necessário à própria vida

Engendra o nascimento

Um instante de crepúsculo

De tudo o que é novo

O neóteno-neguentropo

Em nós o renascido

Que no todo manifesta todas as formas de restauração do elo

Busca da criação.

Pulsão de vida, apesar da morte...

Pelos itinerários desses rios transbordados de gente.

Itinerários de formação

Onde estará a pertença?

Vivemos um desejo de retorno ao uno

Em uma corporeidade finita

Eis o homem forjado

Por suas mãos e as de seus ancestrais

Palavra viva

Que ressoa, soa, voa...

Eco que reverbera a carne e incita o desejo.

De dar pulso ao compasso

Forma que se plasma na matéria entre sístoles e diástoles...

$O$ sopro ancestral e sagrado que pela cultura unifica o verbo, o corpo e a imagem...

Mistério tremendo e fascinante...

Alimentado por um movimento espiral...

Matriz criadora das tradições culturais

Nas suas mais diferentes e coloridas manifestações...

Matriz de impressões

Nas marcas que trago e que imprimo por minhas mãos Marcas das vozes interiores e exteriores que se consubstanciam no grito da existência.

As vozes ancestrais do Imaginário...

(ELISABETE MARTINS DA FONSECA) 


\section{A Fome da Alma}

O grito e a voz terminam em sons e eu os ouço. Como o cristal, o metal e muitas outras substâncias. Sou um ser sonoro, mas a minha vibração, essa é de dentro que a ouço, como disse Malraux: Ouço-me com minha garganta. (Merleau-Ponty,1992, p.47)

Inicio evocando a poesia que grita em meu peito. "A Fome da Alma" é uma poesia que resultou da disciplina Mitohermenêuticas da Arte: Ancestralidade e Criação ministrada pelo professor Marcos Ferreira-Santos, meu orientador neste percurso do doutorado e mestre na vida.

Este texto narrou o vídeo-poesia apresentado no sarau de encerramento desta disciplina, sendo inspirado pelos encontros oportunizados em cada uma das aulas, pela troca gerada entre os cursistas, as leituras, os mitos, as imagens, as vivências e os momentos de deleite pelo reencontro dos sentidos.

Durante as aulas, permitia-me retomar para um espaço que também evocava um tempo. Passado e presente reconciliados após quase dez anos distante da Universidade como aluna regular, especialmente da Faculdade de Educação. Lugar sempre muito especial em minha vida. A escrita da poesia, valeu-se de uma grande contribuição, apreciada e vivenciada a partir do livro Aproximações ao Imaginário: Bússola de Investigação de Marcos Ferreira-Santos \& Rogério Almeida ${ }^{62}$.

Costumo dizer do grande privilégio que tive em meu percurso formativo. Tive a oportunidade de conhecer excelentes mestres. Tanto na vida acadêmica ao estudar na Faculdade de Educação, Instituto de Psicologia e Escola de Comunicação e Artes da Universidade de São Paulo, ao longo de minha graduação, pós-graduação e especializações, quanto em minha atuação profissional na Prefeitura Municipal de São Paulo e nos diversos itinerários de formação pelos quais passei até chegar neste momento da jornada.

E sobre a importância destes itinerários, destaco aqui as palavras de Ferreira-Santos \& Almeida ao afirmar que:

622012. 
Os itinerários de formação pressupõem que não há uma única maneira de se formar, a escolar, mas múltiplos caminhos que se abrem à nossa escolha e que propiciam uma autoformação, ou seja, a aquisição, mas também construção, elaboração, criação de valores, pensamentos, sentimentos que nos situam no mundo, em suas múltiplas manifestações, sejam estéticas, sociais, éticas, psicológicas etc ${ }^{63}$.

Minha experiência durante esta investigação elegeu a autobiografia como uma possibilidade de pesquisa em educação, admitindo que a narrativa autobiográfica possa oportunizar o reconhecimento das marcas geradas pela e na pessoa, que ao narrar expressa o seu modo de ser, o seu imaginário.

Parte-se do princípio de que o imaginário é a força motriz dos processos de criação, e portanto, da formação dos educadores.

Ao narrar meu percurso como educadora reconheço minha autoria, meu modo particular de criar novas experiências a partir das trocas geradas no cotidiano. Evoco a memória para lembrar das experiências marcantes e a partir destas imagens e emoções por elas geradas motivo-me a dar novos passos.

A narrativa de si, como pesquisa autobiográfica, expressa pelo imaginário o sentido da obra a que dediquei minha vida, revelando a diversidade dos itinerários de formação a que tive acesso. Revela-se como uma oportunidade de reelaboração e de imersão no processo formativo, possibilitando ressignificar minha própria história.

Ao escrevê-la pude reconhecer os momentos nos quais fui autora do meu fazer, a partir de escolhas profissionais. Também revivi momentos de conflito, angústia e frustração. 0 compromisso com trabalho na escola pública é uma marca evidente neste percurso, indo das Políticas Públicas às Poéticas Públicas ${ }^{64}$. 0 trabalho como professora de futuros pedagogos ao atuar numa universidade num curso de Pedagogia, reiterou a importância do quanto se faz necessário incentivarmos experiências formativas que envolvam seus participantes integralmente. Não apenas a partir do estudo acadêmico, mas também pela vivência compartilhada em diferentes linguagens, dando voz ao imaginário.

\footnotetext{
63 2012, p.142

${ }^{64}$ Contraponto das políticas públicas como mecanismo institucional e estatal comprometido com uma lógica instrumental e ideológica. Garantidos os espaços, as poéticas públicas são as práticas formativas e organizativas autogestionárias em que a própria comunidade é a responsável e principal protagonista decidindo o quê fazer e como fazer em prol de um bem comum, público, mas não estatal. Veja-se Ferreira-Santos \& Almeida, 2011.
} 
Admito assim, a importância do imaginário na formação dos educadores. Educadores que brincam, cantam, representam, narram, contam, desenham, pintam, modelam; enfim criam compartilhadamente com seus educandos, como pessoas potentes.

Desde a infância a partir de nossos repertórios aprendemos a atuar no mundo. Ao longo da jornada vamos dando forma a nós mesmos a partir da experiência que vai sendo incorporada. A experiência torna-se corpo e alma.

Afinal, é o narrador quem dá forma à obra? Ou é a obra que o expressa?

Por que nos identificamos com determinados autores e suas teorias? Escolhemos ou somos escolhidos?

Nosso corpo pulsa em forma de imagens. Nossas ações, expressões, palavras, sentimentos e pensamentos compõem a imagem no espelho. Mitologia é a poética do corpo cantando a nossa verdade celular, já havia afirmado Keleman.

Foi vivendo a experiência de ouvir meu corpo em movimento que pude ver a imagem da cigana que ele desenhava ao me revelar. Desta imagem surgiu a palavra capaz de narrar. Da carne, ressoaram a imagem e o verbo. Reconheci sua força. Foi o exemplo de um instante de criação, de mitopoiésis:

Podemos afirmar que da relação carnal com o mundo, a partir dos schèmes corporais, temos a imagem arquetípica. Esses esquemas corporais são a gesticulação cultural que engendra uma imagem profunda na psique humana que, por sua vez, se acopla ao inconsciente coletivo, por ser a atualização pessoal da memória humana. A partir das imagens arquetípicas estabelecemos dois caminhos diferentes: um caminho é aquele que cumpre a função cognitiva da imagem transformando seu aspecto exterior em representação. Ficamos com a capa superficial da imagem, com seu valor apenas icônico. Como representação, portanto, serve ao aparelho cognitivo e conceitual, possibilitando a estruturação racionalizante dos conceitos e ideias, pois será pela organização lógica das palavras (logos como razão) que se substitui a imagem icônica, já sem sua força arquetipal. Consubstancia o ideário e a ideologia como constructos reflexionantes, guardando apenas traços arquetípicos latentes (residuais), que exigem um verdadeiro trabalho arqueológico para caracterizá-los.

O outro caminho concomitante é o que faz com que a imagem arquetípica se integre na sintaxe de uma narrativa pela força criadora (poiésis) do mito (processo de mitopoiésis). Salvaguardado como narrativa dinâmica de símbolos e imagens, o mito é, por sua vez, 
aquilo que Durand chama de compleição do aparelho simbólico, a matriz criadora das tradições culturais nas suas mais diferentes e coloridas manifestações ${ }^{65}$.

A cigana. A nômade errante. A nova velha mulher renascida no percurso de narrar-se.

A menina-mulher reconciliada ao seu lobo interior viceja pelos campos, caminha movida pela memória que a recria. No retrato da autobiografia, novos sentidos são atribuídos à imagem. De dentro para fora e de fora para dentro. A imagem desvela-se pela palavra.

Minha rotina nestes dias de escrita procurou também dar voz ao meu corpo. Intercalei em alguns dias, a atividade física, para alongar minhas fibras, tendões e músculos. Busquei realinhar meu corpo também praticando movimentos aeróbios, para ativar toda minha circulação e queimar minha energia. Químicas do prazer foram geradas pelo meu movimento.

Num desses dias de atividade física, ao correr, entrei num estado de transe, enquanto ouvia uma música eletrônica, que trazia uma pulsão ancestral. Em certo momento, teve início uma música que tinha uivos em seu fundo.

Então imaginei que estava correndo com meu lobo interior. Já não se tratava temer o minotauro que me prendia à imagem do labirinto. Mas, à reconciliação com o selvagem que me habita. As vozes interiores de meu animus tomaram meu corpo. Motivada pela música eletrônica que cadenciava suas batidas com uivos, fui entrando num estado de êxtase, onde múltiplas imagens emergiam como insights (lampejos de lumina).

Finalmente a reconciliação com minha força interior. Não como eufemização da figura do monstro ou fuga "do minotauro". Mas na compreensão do instinto e de sua força como potência geradora.

A pulsão do corpo reverberava como força motriz. Na cadência dos passos, sentindo os compassos, que gradualmente, entregavam-me às imagens, ao longo da corrida que gerou transpiração ofegante. Deste estado de transe, senti a palavra percorrendo minha carne. E na pulsão do corpo reanimado pela imagem, via agora o meu lobo interior reconciliado à mulher que corre. Não corre mais de sua força selvagem, por temê-la enquanto instinto ou sombra. Mas corre a partir dela, pelo desejo.

Os uivos remetiam-me à minha ancestralidade. Imaginei uma fogueira ao centro. $O$ fogo sagrado trazia a penumbra necessária para ver de um lado a imagem do giro de uma saia vermelha. Do outro lado, vi um grande touro atraído pelos movimentos da saia.

${ }^{65}$ Ferreira-Santos, 2005, p.113 
Era uma dançarina flamenca. Uma mulher cigana vestida por muitas camadas de renda vermelha.

Dançava em movimentos circulares. Sua dança lembrava as touradas. Ao mover-se sensualmente era levada pela rítmica das palmas em cadência com os uivos harmonizados com o sapatear de seus pés. Ela dançava por inteiro. Pernas e braços firmes, mas delicados o suficiente para encantar o touro, que quase hipnotizado pela leveza dos gestos da dança da vida, emprestava sua força pelo olhar como motivação incessante à dançarina.

Era o animal, a anima e o animus reconciliados pela rítmica gerada entre corpo e alma. 0 instinto animal reconciliado à divindade interior.

A saia vermelha girando em espirais, sublimavam a pulsão sanguínea. O beijo cardíaco gerado entre sístoles e diástoles.

A arte do corpo e o corpo da arte dançavam ao compasso das palmas flamencas. A dançarina entregava-se e integrava-se à imagem de seu touro interior no abraço gerado pelo giro do movimento em espiral.

Uma mulher dançando ou correndo movida por seu lobo interior, não mais fugindo do labirinto ou aguardando um herói vindo de reinos distantes. Descobria a força do que lhe habitava. A força do touro precisava do encantamento de sua saia para sair do lugar.

Eis o casamento sagrado, que pela bem-aventurança compreende o sentido do perdão. Corpo e Alma. Feminino e masculino. O pai e a filha. Nem azul, nem vermelho. Talvez o lilás da aurora ou do crepúsculo no momento da criação. Nem Apolo, nem Dioniso, talvez Hermes. Mas, se fosse Atena já não teria nascido da cabeça de Zeus, mas de seu coração. Então seria Eros?

Guiada pelo amor, somente a tecelã menina-mulher, poderia deixar-se levar por Mnemosina, a tecelã do próprio tempo. Eis a narrativa de si.

Pelo amor e pela memória deu-se a criação: pelo biofluxo do imaginário.

As imagens repousantes do movimento, me levaram a lembrar de um conto, que sempre leio durante as formações. Creio que por seu tom iniciático: As Penas do Dragão. Este é o nome do conto de Arnica Esterl66.

Nesta narrativa um jovem ao lutar por seu amor, inicia uma jornada, buscando conselhos com a sabedoria do dragão.

O dragão que era tão temido, pelo fogo alquímico trazido de sua alma, permite ao jovem acessar a sabedoria. Ao responder as perguntas dos amigos que fizera ao longo de sua jornada, o jovem descobriu o tesouro que só o prazer solidário do estar-junto proxêmico pode permitir.

\footnotetext{
${ }^{66}$ Esterl, 2010.
} 
A sinopse publicada contra-capa do livro descreve esta obra narra a história da vida de um filho de lenhador que se apaixona pela filha de um rico taberneiro. O pai da moça desaprova o casamento e, para consentir a mão da filha ao rapaz, o desafia a conseguir três penas de ouro do dragão. Sem titubear, o jovem, parte para a floresta e, no caminho, encontra outras pessoas que também necessitam do auxílio do dragão.

Proponho fazermos um parênteses para apresentar a história "As Penas do Dragão" na íntegra, tendo em vista, os aspectos simbólicos e estéticos do texto, que dialogam com minha narrativa, revelando novas e velhas imagens. Dedico assim, os próximos parágrafos ao fogo sagrado da anima do dragão que beija o animus da jovem errante em sua iniciação.

\section{As Penas do Dragão}

Arnica Esterl

Era uma vez um hoteleiro muito rico que tinha uma linda filha. Perto de seu albergue, numa choupana, moravam um lenhador e seu filho, o mais belo rapaz da aldeia. Além de corajoso e honesto, o jovem vivia bem-humorado e trabalhava sem cessar, do nascente ao pôr-dosol. Tudo mudou no dia em que seus olhos encontraram os de Lisa, a filha do hoteleiro. Ficou de tal maneira encantado que todo o ânimo e a alegria desapareceram de seu rosto. Lisa também se apaixonou à primeira vista, mas sabia que o pai jamais daria sua mão a um jovem tão pobre.

Só restava aos dois contar ao pai dela os planos de casamento, à espera de sua boa vontade. Foi o que fizeram. O hoteleiro reagiu com uma gargalhada: - Minha filha, não diga tolices! Retire-se já daqui!

$\mathrm{E}$, rindo muito, disse ainda que, para obter a mão de sua filha, o pretendente deveria trazer para ele três penas muito especiais. Penas de ouro, tiradas do dragão que habitava o fundo da grande floresta, a algumas horas da aldeia.

O rapaz aceitou o desafio. Sabia, é claro, que o dragão era assustador e que devorava todos os que ousavam aproximar-se dele. Mas esperava vencer o monstro, usando de astúcia. Não perdeu tempo: partiu imediatamente em direção à floresta sombria, onde se escondia o castelo do dragão.

No caminho encontrou um velho, sentado diante de sua casa. Tinha o olhar tão triste, mas tão triste, que o filho do lenhador não conteve a pergunta: - Por que está tão infeliz, meu bom homem?

- Minha filha está doente há muitos anos - explicou o velho. - O único que poderia curá-la é o dragão, mas... 
- Estou indo justamente para o castelo do dragão - interrompeu o jovem. Eu poderia perguntar a ele o remédio para os males de uma filha. Na volta. Trago-lhe a resposta.

O rapaz continuou sua caminhada e logo passou por uma campina, onde uma multidão se aglomerava ao redor de uma macieira.

- Vocês admiram esta árvore a ponto de passar o dia todo olhando para ela? - ele quis saber.

- Quem dera! - respondeu um jovem. - Se ela ainda nos desse as maçãs douradas de outrora, teria a nossa devoção. Mas veja, meu jovem: a árvore só tem folhas, nada mais. Ajude-nos, eu imploro. Procure o dragão, pergunte o que se pode fazer. Você será bem recompensado.

O filho do lenhador retomou sua jornada. Agora já se aproximava da floresta sombria, coberta de neblina.

Apertando o passo, alcançou um rio, que atravessou na canoa de um velho pescador.

- Há muitos e muitos anos eu faço a travessia desse rio - lamentou o pobre homem - e jamais encontrei alguém para me substituir nessa tarefa tão cansativa. Como eu gostaria se o dragão da floresta resolvesse o meu problema...

Tomado de pena, o rapaz contou o destino de sua viagem e prometeu conseguir uma resposta do dragão. O velho se pôs a chorar, imaginando os perigos que a floresta guardava para aquele rapaz tão amável. Mas suas lágrimas também revelavam alegria pela possibilidade de, brevemente, ver-se livre de seu infindável trabalho.

- Eu tenho dinheiro - garantiu o pescador - e estou disposto a lhe dar uma boa parte, se você me livrar deste martírio.

E chegou, enfim, o grande momento, o jovem apaixonado se viu diante da morada do dragão. Entrou deslumbrado com tanto esplendor. Era um magnífico castelo. O senhor, o terrível senhor do castelo não estava em casa. O rapaz foi recebido pela esposa do dragão, uma moça doce e bondosa, incapaz de fazer mal a alguém.

Gentilmente, ela ouviu a história do rapaz: o velho triste, a macieira, o pescador cansado. Depois prometeu cuidar pessoalmente dos casos e o escondeu debaixo da cama.

O senhor do castelo retornou tarde da noite, mal humorado como nunca. Tão logo entrou em seus aposentos, pôs-se a vasculhar por todos os cantos, esbravejando: - Estou sentindo um cheiro ... um cheiro de cristão!

- Oh, não! - disfarçou a esposa, com ar sedutor. - Aqui estamos somente eu e você... E , à custa de muitas carícias e palavras suaves, ela conseguiu acalmar a fúria do marido.

O casal se deitou e, em pouco tempo, o dragão já tinha caído no sono, roncando assustadoramente. A esposa aproveitou para arrancar uma de suas penas de ouro e 
entrega-la ao filho do lenhador, escondido debaixo da cama. Mas o dragão acordou furioso: - Quem tem a ousadia de me beliscar? - gritou.

- Não se enerve - desculpou-se a esposa, - É que eu estava sonhando com um velho que tinha uma filha muito doente. $\mathrm{O}$ que ela poderia fazer para se curar?

- Se ela quer melhorar, precisa retirar a hóstia consagrada que está escondida sob sua cama - respondeu o dragão, voltando a dormir.

A esposa, então, arrancou outra pena e entregou-a ao rapaz.

- Quem tem a ousadia de me beliscar? - urrou outra vez o dragão, ainda mais irado.

- Calma! Pediu a esposa. - É que eu estava sonhando com uma macieira que costumava dar frutos de ouro e agora só tem folhas. Ai, se eu soubesse como salvar a macieira!

- Basta matar a serpente que vive sob a terra, comendo as raízes da árvore - resmungou o dragão, sonolento.

A esposa do dragão não demorou a arrancar a terceira pena. Desta vez o marido acordou com ódio nos olhos. - Quem está ousando me beliscar? - berrou o monstro horripilante, tentando levantar-se.

A esposa o conteve mais uma vez: - Perdoe-me por favor. É que eu sonhei com um velho pescador, obrigado a transportar os viajantes de uma margem para a outra do rio, durante anos a fio.

- Esse velho idiota deveria ceder seu lugar à primeira pessoa que aparecesse, e depois fugir correndo - grunhiu o dragão. - E agora trate de me deixar em paz, mulher, ou a farei em pedaços.

Tão logo o dragão caiu novamente no sono, o rapaz saiu silencioso de seu esconderijo e foi embora do castelo.

O velho pescador o esperava à beira do rio, aflito para saber a resposta à sua pergunta.

- Leve-me até o outro lado do rio - respondeu o filho do lenhador.

Mal saltou da canoa, na outra margem, transmitiu ao velho o conselho do dragão:

- Assim que aparecer outro viajante para fazer a travessia, ponha o remo nas mãos dele e fuja em disparada.

O velho pescador ficou tão feliz que the entregou uma grande quantia em dinheiro, além de várias propriedades. De ouro e prata o filho do lenhador

Continuando sua jornada, o rapaz chegou à campina, onde a multidão ainda cercava a macieira decadente.

Todas juntas, as pessoas se puseram a cavar aterra, até que encontraram e mataram a serpente. No mesmo instante, lindos frutos dourados começaram a brotar na macieira. A multidão agradecida cumpriu a promessa, cobrindo de ouro e prata o filho do lenhador. 
Quando chegou à casa do velho tristonho, o rapaz se dirigiu ao quarto da moça doente e encontrou a hóstia consagrada escondida debaixo da cama.

- Retire esta hóstia e sua filha ficará curada.

O pai ficou tão contente que repartiu com ele a sua fortuna.

Mas foi Lisa quem mais se alegrou com o retorno do rapaz. Olhava para seu bem-amado com um ar apaixonado e segurava suas mãos quando o pai chegou. O hoteleiro, agora, estava mais do que satisfeito com a ideia do casamento, pois o rapaz tinha voltado muito mais rico do que ele.

- Mas onde você encontrou tantas riquezas? - perguntou avidamente.

- No fundo da floresta, no castelo do dragão - respondeu o filho do lenhador. - Lá as riquezas rolam no chão. É só baixar-se e apanhá-las.

Advinhe o que aconteceu quando o hoteleiro chegou à margem do rio e pediu ao velho pescador que o levasse até o outro lado!

O jovem casal convidou as duas famílias e todos os amigos para a cerimônia de casamento. Todos estavam muito alegres e sorridentes, mas os dois eram, sem dúvida, os mais felizes de todos.

A primeira vez que eu ouvi esta história foi durante uma formação. Lembro do quanto fiquei encantada com a história desse jovem apaixonado, um herói místico. Além dela conter, como linha mestra, a aventura da jornada, de alguém que generosamente ajuda-se ao ajudar outras pessoas, outras imagens atraíram minha atenção, para posteriormente, voltar a reler a história, tendo o prazer polissêmico de fazer novas analogias. Em cada leitura, identificava-me com um personagem. Metaforicamente, qual lugar ocuparia nesta jornada? E concluí que me identifiquei com todos. Refleti que durante nossa jornada, compartilhamos histórias. É a travessia que permite a transformação. Imergindo na floresta sombria, transpondo as águas, dialogando com o dragão. Talvez nosso próprio inconsciente. Poço mítico e místico. Somente ouvindo a bela esposa, a imaginação em nossa anima, podemos responder as perguntas que movem nossas vidas. Nessa travessia, símbolos foram evocados, com os quais também me identifiquei: a travessia enfrentada para unir o masculino e o feminino, num processo amoroso. Luz e sombra. Razão e Imaginação. Castelo, dragão, jovem doente, árvore, rio, sacrifício, serpente, mulher sábia, jovem donzela e seu prometido: animus e anima reequilibrados, movimentam-se juntos. Neste giro restaurador curam, oxigenam, frutificam, florescem e reencantam tudo o que está à sua volta. A relação gerada pela aproximação dos opostos 
alcançando ao seu término um casamento evoca, mais uma vez, a imagem da reconciliação que promove a justiça. Da compaixão que supera o orgulho e o egoísmo.

O outro aspecto que devo salientar é a minha fascinação pela imagem do dragão. Sempre gostei de histórias envolvendo sua temática, seja quando assume um papel de monstro, seja quando assume o papel de salvador. Sua imagem de uma forma ou de outra evoca a sabedoria, o poder e a realização do impossível.

E segundo Campbell:

Simbolicamente, a serpente é a força vital ligada à terra. Ela troca de pele quando a Lua muda e, portanto, representa alguma coisa mais profunda e mais contínua do que determinado momento na vida. Ela troca sua pele, troca uma personalidade, troca um estilo de vida e se transforma em outra. E assim, torna-se simbólica da força vital no tempo e no espaço. O pássaro, por outro lado, está desligado da terra e representa o poder do vôo espiritual. Assim, os dois estão em oposição. Você tem a serpente que hipnotiza e depois devora o pássaro; ou tem o pássaro - um falcão ou uma águia - arremetendo-se sobre a serpente. Esse é o par de imagens que aparece em todos os tipos de mitologia. E a junção dos dois é o dragão, a serpente voadora. Essas são imagens muito estranhas. As duas, nascidas nos velhos tempos dos dinossauros, o pássaro e as escamas da serpente são equivalentes e entre elas está o mamífero, do qual o mais elevado, do meu ponto de vista, é o ser humano. Ele se encontra esses dois poderes. ${ }^{67}$

É como na lenda de Parsífal e no conto Carne de Língua. As forças do imaginário restaurando os reinos devastados. O ser humano em constante construção pela dialogicidade desses poderes, edifica seu castelo interior. Sendo o próprio Graal.

Durante as aulas ao frequentar as disciplinas ao longo do doutorado, estive nessa travessia buscando restaurar o reino devastado. Ao narrar fui levada pelas imagens. Uma delas a da velha sábia mulher. A cigana. Aquela que caminha. Que respira o sopro de lumina profundis:

Essa região selvagem originária (Ursprungs), campo de forças da criação, se inscreve na corporeidade do Ser. É em meio à corrente sanguínea, na tensão da tessitura muscular, na anatomia líquida dos hormônios, na sístole/diástole cardíaca, na combustão pulmonar, na ascensão postural, no recolhimento fetal, na cópula e no ritmo equilibrante dos passos que engendramos nossos arquétipos em flor. É a partir de schèmes corporais que geramos nossas imagens arquetípicas. Nesse sentido é que podemos dizer que a imagem se inscreve no corpo e é sua própria escritura. Ou ainda, que: trata-se deste logos que se pronuncia

\footnotetext{
${ }^{67}$ Campbell apud Keleman, 2001, p.104
} 
silenciosamente em cada coisa sensível, enquanto ela varia à volta de certo tipo de mensagem, de que só podemos ter ideia através de nossa participação carnal no seu sentido, esposando com o corpo a sua maneira de significar - ou deste logos proferido, cuja estrutura interna sublima a relação carnal com o mundo ${ }^{68}$.

A imagem da dançarina flamenca que evocou a cigana, a velha sábia, menina-mulher, lembroume do livro: A Ciranda das Mulheres Sábias: Ser Jovem Enquanto Velha, Velha Enquanto Jovem ${ }^{69}$.

A imagem da velha sábia mulher que cura e acolhe liga-me à figura de minhas avós. Pude conhecê-las. Toquei seus cabelos prateados pelo tempo. Macios como os carinhos de suas mãos. Ligada a elas, minhas avós, emerge a imagem de seus quintais, por onde percorreu meu imaginário desde a infância cercado pelas plantas, aromas, temperos, ervas, sementes, flores, tecidos, linhas, causos e rezas.

Quantas vezes éramos curados eu e meus primos, minha irmã e toda nossa família por seus chás e por suas orações. Minhas duas avós e minha mãe, mulheres que com seu amor eram capazes de criar, curar, cuidar.

Estés ao escrever sobre a Ciranda das Mulheres Sábias indica um tipo especial de mulher velha jovem:

Existe também o tipo de abuelita, grande avó, que se caracteriza não só por sua perspicácia mas por seu profundo amor. Nos mitos, como curandeira, que mora em algum lugar muito afastado, ela é a avó querida e prendada que produziu o pão do amor. Quando ela o serve, esse pão transforma para o bem quem quer que o coma.

(...) La abuelita, a vovozinha humana, é uma combinação de características e qualidades que, para a família ao seu redor, costumam também parecer mágicos. Pode ser seu conhecimento de ervas, as plantas que ajudam e curam o corpo e o espírito. Pode ser seu talento para o insight. É ela quem distingue a falsidade da verdade mil metros de distância. Ela consegue ver exatamente que ações gerarão lembranças dignas de guardar. Ela pode ser aquela que cozinha como um anjo e ao mesmo tempo ameaça usar a cinta reforçada, cheia de botões pendurados e ganchos de metal para as meias, como um estilingue para atingir quem não se comportar com o devido respeito. Em todas as abuelitas, como a velha Deméter que cura uma criança doente com um beijo, o espírito atravessa a perda e então volta para o amor, e para o amor de novo. Isso mesmo. Para as abuelitas, vovozinhas, a vida cheia de recursos costuma emanar do tecido em cicatrização. As abuelitas foram testadas

\footnotetext{
${ }^{68}$ Ferreira-Santos, 2005, p.112

${ }^{69}$ Estés, 2007.
} 
pelo tempo. Elas são aquelas que não apenas sobreviveram, mas que também se dedicam à tarefa de vicejar ${ }^{70}$.

Ao cursar a disciplina Mitohermenêuticas da Arte: Ancestralidade e Criação ministrada pelo professor Marcos Ferreira-Santos, assisti ao documentário Sementes do Nosso Quintal (2012). A partir do documentário visitei a escola Te-Arte e conheci Therezita Pagani. Na clara manhã em que visitei a escola, tive uma experiência diferenciada em minha vida. Enquanto caminhava pela escola, voltei a um quintal mágico. Era o da casa de minha avó. Pomar frutífero da memória por onde brotaram as memórias das brincadeiras, as vozes de minha avó, de minha mãe, minhas tias e primos. Ocorreu que num instante passado e presente estavam unidos na experiência de percorrer o quintal. Fui tomada por uma grande emoção. Sons, cheiros, gestos e palavras que afirmaram na voz da parteira de almas de cabelos prateados: Therezita Pagani, a matriarca. A realização do arquétipo da mulher-sábia. Daquela que acolhe sem ser mansa. Que acaricia ao estabelecer os limites. Daquela que sabe podar a rama, para não perder o fruto. A partir do retorno ao "Quintal Mágico"71 de minha infância, que reconheci, minhas próprias memórias como tema de investigação do Doutorado. Reconheci que era da minha narrativa que poderia ressignificar a formação do educador pelo imaginário. Estava tentando "escreviver"72.

\footnotetext{
${ }^{70}$ Estès, 2007, p. 54-56

${ }^{71}$ De Volta ao Quintal Mágico: A Educação Infantil na Te-arte (2006) da jornalista Dulcilia Schoeder Buitoni. A autora, jornalista e mãe de três ex-alunos, fez da escola tema de sua livre-docência na ECA-USP, que deu origem ao livro. Nele, a autora documenta a história da Te-Arte, por meio de depoimentos. A Te-Arte, escola criada por Therezita Pagani para crianças de nove meses a sete anos, continua sendo um modelo pioneiro, original e eficiente de "educação orgânica". Muitas coisas a diferenciam das escolinhas convencionais. Não há classes nem turmas divididas por idade. E algumas crianças especiais são incluídas desde sempre. Privilegia-se o brincar usando como elementos e referência a natureza, a arte e a cultura popular. Num jardim-pomar com trilhas e bichos, homens e mulheres de diferentes profissões alternam-se em todas as atividades. Criatividade, liberdade e respeito aos limites são palavras-chave. Para Therezita Pagani, criança que brinca bastante saberá construir sua identidade $s$ será um aluno melhor na escola formal. Portanto, a ordem é brincar. Mas não um brincar aleatório, $\mathrm{O}$ papel da TeArte é justamente o de fornecer elementos, estímulos e apoio para a brincadeira, uma forma de educação que respeita o ritmo e a necessidade da criança. A convivência de crianças de todas as idades, com a inclusão de algumas especiais e de adultos não necessariamente professores, ensina a variedade, o respeito mútuo e a solidariedade. Valores fundamentais com os quais várias gerações de jovens que passaram pela escola já enfrentaram o mundo com muita sabedoria.

${ }^{72}$ Com referência ao trabalho de Elni Elisa Willms: Escrevivendo: uma fenomenologia rosiana do brincar - Tese de Doutorado - FEUSP - 2013. Segundo a autora em sua tese procurou ampliar alguns limites da escrita acadêmica para tratar do brincar na Casa de Recreação Te-Arte, acolhendo a poética de Guimarães Rosa como suporte epistemológico e metodológico. Afirma a filosofia trágica de Friedrich Nietzsche, a fenomenologia dos quatro elementos de Gaston Bachelard e da percepção de Maurice Merleau-Ponty. Sobretudo a sabedoria poética de Rosa e de Bachelard, sendo que Guimarães Rosa pode ser considerado também etnógrafo. A partir do vivido de seu Diário de Campo foi ressignificando o que estava à sua volta, pelas descobertas das crianças bem pequenas, misturando aos elementos da cultura popular e à poética de Guimarães Rosa, engrandecendo este gesto ancestral o brincar. Trata-se, portanto, de uma investigação que está nas imediações da antropologia e da fenomenologia,
} 
Sementes do Nosso Quintal nasceu do desejo de sua realizadora Fernanda Heinz Figueiredo de contribuir para reflexão de um olhar mais sensível para a infância por meio da divulgação do trabalho pioneiro, atemporal e persistente da escola Te-Arte em São Paulo, a sua primeira escola. Fundada em 1975 pela educadora capixaba, Therezita Pagani, hoje com mais de 80 anos de idade, a Te-arte é um espaço vivo e orgânico, em constante crescimento e mutação, e que deixa marcas profundas em todos que por ali passam. Para refletir os princípios dessa pedagogia orgânica da simplicidade, que acolhe a vida como seu principal insumo de trabalho, optou-se por uma abordagem de cinema direto, abrindo-se as portas da escola para que o expectador vivencie o cotidiano ao lado das crianças, suas famílias e educadores. O roteiro também se fez em cima de um processo de autorreflexão, rompimento e crescimento pelo qual passa toda a comunidade escolar, cada qual ao seu modo, e que não poupou os realizadores do filme. Por isso o estranhamento inicial, que nos tira do lugar: a morte, a separação, a destruição, o choro, o luto, temas que nos conectam enquanto humanos, fundamentais para o rompimento de cordões, rótulos, modelos externos, pressa e apatia. Um ritual de passagem, que por vezes implica em sofrimento, mas que nos conduz a transformações, a uma vivência do tempo e do ser. Uma experiência viva, comunitária, avessa a didatismos, teorias e tecnicismos. 0 filme retrata o cotidiano de uma escola de educação infantil sem precedentes que, através do pensamento-em-ação de sua idealizadora, a controversa e carismática educadora Therezita Pagani, nos revela o potencial estruturante de uma educação verdadeira, firme e sensível. Somos levados a uma escola onde a criança está acima de métodos e fórmulas de se educar. Onde natureza, música, arte, conflitos e cultura popular regem o encontro das crianças, que convivem diariamente entre diferentes faixas etárias. Sementes do Nosso Quintal é, antes de tudo, um filme que trata da vida de todos nós, através de uma escola. Sementes do Nosso Quintal, um filme de Fernanda Heinz Figueiredo, inspirado na força de Therezita Pagani. Argumento de Jorge Saad Jafet e Fernanda Heiz Figueiredo. Roteiro de Renata Meirelles e Fernanda Heinz Figueiredo. Consultoria de Roteiro Eduardo Benaim e Marcos FerreiraSantos. Trilha Sonora: Tião Carvalho, Duo Bico de Pena, Paulo Dias, Caixeiras da Família Menezes e Barbatuques ${ }^{73}$.

\footnotetext{
mas que flerta com a literatura de Rosa para tratar de três núcleos do brincar: corpo, experiência e iniciação, a partir das experiências vividas na Te-Arte, um espaço de aprendizagem e uma experiência singular em educação, concebida e dirigida pela educadora Thereza Soares Pagani, a Therezita, em São Paulo. A Te-Arte existe desde 1975 e se distingue por não ter sala de aula, professores por turma e nem divisão de crianças por faixa etária. 0 que a autora narra em sua tese não é algo que possa ser disseminado como política pública, talvez como poética pública, como sugere Marcos Ferreira-Santos. O texto mostra os desafios de uma Pedagogia da Escolha anunciada por Rogério de Almeida e Marcos Ferreira-Santos, acolhendo outras linguagens para dialogar e deixar mostrações de uma educação de sensibilidade postulada pelos mesmos autores.

${ }^{73}$ Texto de apresentação do DVD do filme "Sementes do nosso quintal", Nzinga Produções, 2012.
} 
O encontro com Therezita Pagani representou o reencontro com minhas avós e minha mãe - e com a grande mãe que me habita. Lembrar delas ao conhecer e conversar com Therezita foi algo intenso e imediato. As mulheres sábias e parteiras começaram a tecer seu processo de cura. As linhas da escrita autobiográfica foram sua forma de expressão.

As brincadeiras realizadas na minha infância revestem-se de significado nestes itinerários de formação. O quintal da casa dos meus pais e de minha avó materna, que na perspectiva de adulta, parecem tão pequenos, agigantam-se na perspectiva do imaginário.

Desde a infância já somos esta pessoa potente. Potentes em todas as criações do pensamento humano - que engloba a produção poética, artística, mas também a científica, filosófica, ideológica etc.

Em minha infância, os personagens vividos me permitiam viver múltiplas histórias. Preparando minhas comidinhas tendo como repertório muitas horas de observação, imitação e interação com minha mãe, irmã, avós, tias e primos.

Quando dançávamos, desde o forró, herdado de minha origem de pais nordestinos, até as então novas influências da discoteca, alimentávamos nossos corpos de cultura ${ }^{74}$.

Sabores, cheiros, cores, canções, risos e silêncios. Quando também brincava de escolinha com minhas bonecas, ficando tardes inteiras imersa no prazer de vivenciar novos papéis, reinterpretando meu cotidiano. Minha irmã (que é oito anos mais velha que eu) foi minha iniciadora nos processos escolares. Ensinava-me a ler e escrever. Compartilhava livros, histórias e pincéis.

Como não tive a oportunidade de frequentar uma escola de educação infantil, meus itinerários pelo ler, brincar e imaginar foram construídos em casa com a participação da família e de alguns vizinhos. Não havia muitos livros, mas os que chegavam às minhas mãos eram devorados.

Para além da infância, o brincar, a literatura, o cinema, o teatro, a música, a prática esportiva são exemplos de itinerários possíveis de minha autoformação.

Celebrar, festejar, inventar, criar um brinquedo, uma história e seus diversos cenários. Brincar de bonecas, carrinhos, cabanas, esconde-esconde etc.

Aprender a movimentar o corpo livremente seja correndo no quintal ou aprendendo um treino numa academia. Dependerá sempre de nossos repertórios, das oportunidades que a vida nos

\footnotetext{
74 "A cultura, então, seria vista nessa perspectiva mais simbólica como o universo da criação, da transmissão, da apropriação e da interpretação dos bens simbólicos e das relações que se estabelecem" (Ferreira-Santos \& Almeida, 2012, p. 14).
} 
ofereceu para além de quaisquer determinismos materiais. Muitas destas experiências também foram garantidas pela fantasia, no jogo simbólico do faz de conta e na fruição das vivências.

Por essa perspectiva, os itinerários de formação valorizam a complexidade, os processos simbólicos que perfazem a cultura, a razão sensivel, a construção de si, a obra de arte e a arte-educação, a dimensão ética e estética da vida, a pluralidade e a prática de uma pedagogia da escolha e de todas as atividades fundamentais para a formação da pessoa ${ }^{75}$.

Pessoa compreendida na perspectiva do termo grego prósopon e não apenas como persona, possível máscara social ou psicológica que nos ocultaria:

Aquele que afronta com sua presença, que ressoa no mais íntimo de si mesmo, como construção cotidiana, provisória e paradoxal, que se dá no embate entre a pulsão subjetiva em sua vontade de transcendência e a resistência concreta do mundo em sua facticidade, opacidade aos nossos desejos e vontades ${ }^{76}$.

Pelas imagens, pelos desejos e pelo ressoar da poesia, esta pessoa seria a resultante de uma troca incessante, construída num trajeto antropológico: "A incessante troca que existe ao nível do imaginário entre as pulsões subjetivas e assimiladoras e as intimações objetivas que emanam do meio cósmico e social ${ }^{77 " .}$

Afrontar a vida com a nossa presença diariamente sabendo de seu caráter inconcluso e de inacabamento em permanente tensão. Esta é a bem-aventurança a que estamos destinados. Permitir o fluxo da troca entre o desejo e o enfrentamento da realidade. Sentindo e pensando meios de transformar as condições de nossas vidas para alcançarmos nossos desejos. Permitindo-nos imaginar. Sendo o hoje e o amanhã. E também sendo gratos ao que experimentamos ontem. Deixando-se levar pelo imaginário, vivenciando, experimentando. Ouvindo nossas vozes interiores.

Nesse processo de fluxo e refluxo, de pulsões e ações, pensamos estar modificando nosso meio, nossa vida, nossa condição econômica e social. Mas, a grande transformação encontra-se em nosso interior. Transformação não linear, nem previsível, nem mensurável.

Às vezes, podemos até nos queixar das dificuldades ou obstáculos durante o caminho. Mas, passados alguns minutos, dias, meses ou anos, percebemos que tudo aconteceu exatamente da maneira que precisávamos. Então nos afrontamos com a presença da pessoa que somos, por

\footnotetext{
${ }^{75}$ Ferreira-Santos \& Almeida, 2012, p. 143.

${ }^{76}$ Ferreira-Santos \& Almeida, 2012, p. 129.

${ }^{77}$ Durand, 1997, p.41
} 
aquilo que também fizemos de nós mesmos e para nós mesmos, apesar de não termos feito tudo isso sozinhos.

Lembro aqui Joseph Campbell ao tratar dos temas sacrifício e bem-aventurança, numa entrevista, responde que:

Cada um possui a sua própria profundidade, a sua própria experiência, e alguma conviç̧ão quanto a estar em contato com a sua própria sat-chit-ananda, isto é, seu próprio ser, através da consciência da bem aventurança. Os religiosos dizem que não chegamos a experimentar verdadeiramente a bem-aventurança antes de morrermos e irmos para o céu. Mas eu acredito em atingir o máximo possível dessa experiência enquanto estamos vivos. Pois o tempo todo é milagroso. Tenho até mesmo uma superstição, que se desenvolveu em mim como resultado dessas mãos invisíveis agindo o tempo todo, a superstição, por exemplo, de que, pondo-se no encalço da sua bem-aventurança, você se coloca numa espécie de trilha que esteve aí o tempo todo, à sua espera, e a vida que você tem que viver é essa mesma que você está vivendo. Quando consegue ver isso, você começa a encontrar pessoas que estão no campo da sua bem-aventurança, e elas abrem as portas para você. Eu costumo dizer: Persiga a sua bem-aventurança e não tenha medo, que as portas se abrirão, lá onde você não sabia que havia portas. Onde quer que você esteja, se estiver no encalço da sua bem-aventurança, você estará desfrutando aquele frescor, aquela vida intensa dentro de você, o tempo todo ${ }^{78}$.

A bem-aventurança descrita por Campbell remete-nos ao que Ferreira-Santos \& Almeida chamam de amor fati, por suas palavras seria:

Aqui se trata da fórmula magistral de Nietzsche que nos parece continuar válida: amor fati (amar seu próprio destino), que, por sua vez, é tributário de Arthur Schopenhauer. Diz o próprio Nietzsche: Minha fórmula para a grandeza do homem é amor fati: não querer nada de outro modo, nem para diante, nem para trás, nem em toda eternidade. Não meramente suportar o necessário, e menos ainda dissimulá-lo (...), mas amá-lo. A condição trágica deste "amar o seu próprio destino" pressupõe uma pessoa que tenha condições de elaborar o seu próprio quadro de valores para pautar suas atitudes. Portanto, a noção se articula com a vontade da potência e, de maneira paradoxal, mas muito coerente com o espírito nietzschiano, com a aceitação ativa de seu destino. Lembra, o mestre Shopenhauer, tanto "(...) assim como o fatum pairava sobre os deuses dos antigos". O fatum, ou de maneira saudosa e poética, assimilado ao português, o fado, equivale simbolicamente à fata (fada, aquela mesma dos contos de fada - que conduzem ao destino), ou ainda, à sua expressão

\footnotetext{
${ }^{78}$ Campbell, 1990, p.127
} 
medieval na figura de uma jovem adolescente que nos cruza inesperadamente o caminho, como Saga. Dessa forma, o caráter trágico da aceitação da liberdade, entre as opções que nos são dadas. Mais propriamente, poderíamos falar de destinação para contrapor qualquer leitura mais rápida e superficial que pudesse endossar alguma pré-destinação fatalista. Os caminhos se abrem à medida do caminhar. Mas, uma vez optado por um determinado caminho, mil outros se fecham às nossas costas. Permanecer preso às opções não escolhidas equivaleria a ficar preso ao passado e perder a força de sua vontade de potência. Daí, para Nietzsche, a necessidade de amar o seu destino ${ }^{79}$.

Destino ou caminho, nossa história é feita de encontros, desencontros e reencontros. Somos produzidos pelo cruzamento de outras histórias que se fundem à nossa. Amores, amizades, vínculos familiares, profissionais, afetos e desafetos. Momentos milagrosos nos quais nos reconhecemos sobreviventes num mundo tão contraditório quanto cada um de nós.

Não somos seres idealizados. Somos permeados pela álea. A trágica condição de nos sabermos estar em contagem regressiva. Como chama viva, nos consumimos. Entropia que se nega. Diálogo entre caos e ordem. Somos cosmogonia neguentrópica. Únicos na escolha do caminho. Múltiplos em nossa destinação.

Herdeiros de uma condição que transformamos, sublimamos e reverenciamos. Amando o fato de estarmos vivos como obras em constante inacabamento. Nossos caminhos se abrem ao caminhar.

Lembro aqui do meu próprio percurso. Filha de pais nordestinos. Chegaram em São Paulo, muito jovens e cheios de expectativas, buscando melhorar suas vidas e de suas famílias. Meu pai, nascido na Bahia. Minha mãe, em Sergipe. Famílias grandes, cada um tinha dez irmãos. Meu pai trabalhou em vários empregos, desde a construção civil até a metalurgia. Minha mãe também trabalhou em vários segmentos, da área doméstica até montagem de equipamentos eletrônicos. Eles se conheceram em São Paulo.

Casaram-se após alguns anos de namoro e superaram muitas dificuldades para se estabelecerem. Tiveram duas filhas. Eu e minha irmã. Temos oito anos de diferença. Sendo eu a mais nova.

Eu me lembro dos meus pais, que com muito sacrifício e dedicação construíram literalmente nossa casa, trabalharam muito. Lembro-me de brincar naquele quintal que estava sempre em movimento de construção. Parede a parede, degrau a degrau nossa modesta casa foi erguida.

${ }^{79}$ 2012, p. 13 
Lembro-me de estar sempre brincando em casa, com miniaturas, bonecas, no quintal, de escolinha. Gostava de ler livros, estudar imitando minha irmã que era sempre generosa em me ensinar o que ainda estava aprendendo. Assim, já em minha segunda série comecei a ajudar meu vizinho a aprender a ler. Era uma brincadeira e me sentia feliz em poder ter a presença do meu coleguinha e perceber que ele também gostava de estar ali. Não sei ao certo o quanto pude ajudá-lo de fato, mas me lembro desta experiência com muita gratidão. Também brincava com outra vizinha que tinha uma coleção de livros ilustrados. Haviam princesas e eram muito coloridos. Neles ia desafiando minhas aprendizagens no mundo da leitura e não parei mais.

Sempre muito aplicada às leituras, fui criando um jeito próprio de estudar. Estimulada mais por minha mãe e minha irmã, também comecei a gostar de escrever versos, rimas e de inventar músicas. Gostava de desenhar e pintar. Lembro-me de uma coleção de lápis de cor que apesar de usá-los muito, os mantive muito bem cuidados em sua caixinha por muito tempo. Tudo era fruto de muito trabalho e sacrifício dos meus pais. Aprendi a valorizar cada conquista, apesar de nem sempre ter todos os brinquedos, que insistentemente, eram apresentados pelos comerciais de televisão.

Às vezes era confidente de minha mãe e de minha irmã. Meu pai era um homem forte, batalhador e honesto. Algumas vezes, muito ansioso, preocupado com as dificuldades financeiras que enfrentávamos. Minha mãe sempre o ajudava sem deixar de estar presente em nossa educação.

Desde esse tempo, ouvia dela que a mulher precisava estudar para conseguir conquistar os meios de sobreviver de forma independente.

Aos poucos, fui começando a entender que as relações não são ideais. Elas acontecem de acordo com a possibilidade da contraditória condição humana. Talvez por eu não ter muitos colegas de minha idade, lembro que tive dificuldades em me adaptar à escola.

Preferia estar no meu quintal, com meus livros, minha mãe e tudo o que me transmitia segurança. Foi na escola que descobri sofrer de uma alta miopia, que até hoje me acompanha. Acredito que a sensação de insegurança gerada pela escola, também se deva ao fato de não enxergar e me sentir perdida, sem mesmo saber o que estava acontecendo.

A alegria gerada pelo uso dos óculos, aos sete anos, só foi superada pela felicidade de usar lentes de contato aos treze anos, quando o seu uso começou a interferir em minha autoestima. Foi algo transformador e libertador poder me ver no espelho sem nada entre meus olhos e minha imagem, pelo menos algo visível. 
Meus "novos olhos" davam expressão ao que via, falava, ouvia, inspirava e tocava. Esta memória ressaltou a importância da visão como sentido e projeção. Mas principalmente sobre a importância do olhar. O sentido da visão é algo que nos liga ao mundo. Mas, é especialmente, quando fechamos os olhos, e nos olhamos por dentro, é que vamos construindo nossa própria imagem. É também interagindo como o outro, a partir do seu olhar, por identificação ou diferenciação, que aprendemos a reconhecer outros ângulos desta imagem. 0 olhar integra todos os sentidos. A sensibilidade do olhar vem com a possibilidade de nos permitirmos sair de nosso lugar e experimentar outros pontos de vista, colocando-nos na pele do diverso semelhante.

Passei a gostar mais da minha imagem sem os óculos. Meus olhos ampliavam minha expressão. Sentia-me mais autoconfiante. Creio que isto tenha interferido positivamente em minha relação com meus colegas. Fiquei mais expansiva, pois até então, era muito introvertida. Tinha poucas amizades e nem sempre tinha coragem de responder às perguntas feitas, pelos professores, apesar de ter boas notas nas provas.

Como disse, mesmo antes de ir para a escola, fui alfabetizada e desenvolvi meios de aprender. Vasculhava os poucos livros didáticos e literários que chegavam às minhas mãos. Eram bens muito preciosos ainda quando eram de segunda mão. Estes já vinham com grifos e anotações que passei a valorizar, pois completavam informações nem sempre apresentadas pelos textos. O mundo da cultura ia tecendo minhas entranhas, meus desejos e percepções. la ampliando minha míope visão de mundo.

Estudava numa escola pública estadual. Ela não tinha parque. Mas tinha biblioteca. Gostava de participar de várias ações da escola, como mutirões de organização. Talvez nessas ocasiões, sem perceber ia desenvolvendo minha liderança. Minha experiência mais marcante de liderança aconteceu na sétima série, quando realizamos uma peça teatral. Cada um de nós, eu e meus colegas aprendemos muito juntos, apesar da maior greve que me recordo ter vivido como aluna. A apresentação teatral foi uma alternativa de reposição que oportunizou escrevermos, dirigirmos e ensaiarmos com muita autonomia. Com escassos recursos apresentamos a peça. Além de escrevê-la e dirigi-la, fui sua narradora. Foi uma experiência inesquecível. Através dela estreitei laços de amizade e passei a confiar mais em mim.

Neste mesmo ano, comecei a dar aulas de reforço em minha casa. Comecei ajudando alguns colegas nas matérias que tinham dificuldade e quando percebi já estava trabalhando.

Isto me ajudou a aprender a ganhar meu próprio dinheiro, mas principalmente, a estudar cada vez mais, pois às vezes era desafiada a ensinar algo que eu nunca tinha aprendido. Então 
aprendi o quanto era importante pesquisar. Mais uma conquista libertadora em minha vida. Não desistir diante do desconhecido. Perseverar para além do limite e compartilhar a maneira como aprendi com aqueles com quem trabalhava. Era muito gratificante aprender assuntos novos.

Outra experiência marcante foi perceber o quanto confiar na potência do aprendiz se faz necessário. Por confiarem em mim, que eu conseguiria aprender que tinha a certeza que todos eles poderiam aprender, pois eu não era diferente de ninguém. Talvez eu fosse apenas um pouco mais teimosa, curiosa e persistente.

Foram tantas situações vividas. Percebia crianças que chegavam para ter estas aulas de reforço muito descrentes de si mesmas, algumas muito tristes, outras mais rebeldes, porque não aceitavam a condição de não aprenderem e de serem rotuladas por isso. Cada uma, em seu próprio ritmo foi superando seus limites. E quando isto acontecia - e eu me tornava desnecessária, por já terem recuperado suas notas ou aprenderem fazer suas tarefas e estudos sozinhos - era um momento mágico. Assim fui me envolvendo e me desenvolvendo junto com eles. Assim, os aprendizes foram me ensinando o ofício de ensinar. Por esta experiência, pelo incentivo de minha mãe e a experiência de minha irmã que já era professora, decidi pelo Magistério.

Sabia que as crianças, adolescentes e alguns adultos que tinham aulas particulares comigo iam conseguir alcançar suas metas. Tinha a convicção de que eles traziam em seu interior tudo o que precisavam. Eles só precisavam de ajuda para extraírem de si mesmos sua força. Acreditarem em si mesmos.

Nossos sentimentos e pensamentos se cruzavam a partir dos vínculos que criávamos. Aos poucos, tornava-se mais explícito ao aprendiz suas próprias motivações e potencialidades. À medida que ia conhecendo a história de cada um deles, desenvolvia um diálogo, sempre reconhecendo seus avanços e perguntando a eles quais seriam os novos passos a serem dados em suas jornadas de aprendizagem.

Lendo Ferreira-Santos \& Almeida, ao tratar da humanitas: a educação entre as estruturas de poder e a potência existencial, reconheci esta mágica possibilidade de como educadores, parirmos almas, já possuidoras da potência motriz. Nas palavras dos autores:

Parece-nos que fica evidente a força que esse trabalho parideiro tem sobre a reapropriação do aprendiz, sobre sua constituição como sábio de si mesmo e dar à luz suas próprias ideias, sem que o iniciador/mestre/parteiro imponha suas próprias verdades como resposta. Nisto se constitui a ironia socrática: fazer através do diálogo, com que o interlocutor perceba e 
admita sua ignorância. (...) Lembremos que Sócrates inicia sua saga na polis ateniense com a tarefa racional de fazer seus interlocutores parirem suas próprias ideias, atualizarem a humanitas de cada um; mas essa empreitada racional tem um caráter sagrado. Como adepto dos mistérios délficos, Sócrates utiliza a máxima do portal do templo de Apolo em Delfos: "conhece-te a ti mesmo" e "age com moderação". Ainda que hoje nos pareça contraditório, a justificação da tarefa racional é uma devoção religiosa, no sentido mais profundo do termo: religare, como disponibilidade para nos religarmos uns aos nossos outros. Possibilitar uma comunhão: Baraka, como o termo sufi presente em várias culturas diferentes com o significado de bendição ${ }^{80}$.

Não deixei de dar estas aulas particulares até iniciar em 1999 o meu segundo cargo como professora na Prefeitura Municipal de São Paulo.

Tenho a certeza interior da força desta prática maiêutica. Parir os aprendizes é um instante de renascimento do próprio mestre ainda que não se saiba como tal. Trazer a força motriz à luz é descobrir os caminhos que nos religam ao nosso si-mesmo.

Estas aulas particulares, inicialmente, aconteciam, num quarto da casa dos meus pais. Antes de ser este espaço de estudo, era o quarto da minha vó paterna. O distanciamento do tempo me permitiu considerar esta informação com um novo significado. Era ali, que passávamos eu e minha avó bastante tempo juntas. Gostava de ouvir seus causos, de ouvir e participar de suas orações. Como "filha de Maria", minha avó católica fervorosa, rezava terços diariamente. Hábito também vivenciado com minha mãe. Ouvir a palavra sagrada, ressoante, revestiu as paredes desse quarto de memória, amor e criação. Somente ao escrever esta narrativa pude reconhecer pelas palavras de Berdyaev, o poder deste espaço, no qual dava aulas particulares e como autodidata estudava para aprender, completamente envolvida. Numa destas vezes, tive como desafio estudar para o vestibular.

Lembrei como advertia Nikolay Berdyaev que as grandes forças que combatem pela pessoa no mundo são a memória, o amor e a criação $0^{81}$.

Este "quartinho" localizado do lado da cozinha e de um quintal no qual tínhamos uma perfumada "dama da noite" foi o espaço-matriz das aulas particulares. Lugar encharcado de afetividade. Ligado aos aromas da cozinha. Outro fecundo elo com as alquimias da cozinha, onde minha mãe transformava sementes em alimento. Também compartilhado com minha irmã em seus estudos. Os aromas dos temperos alimentavam minha fome. Não apenas a

\footnotetext{
80 2011, p.22-3

${ }^{81}$ Berdyaev, 1957.
} 
digestiva, mas a fome anímica. Quintal de mãe, de pai, de avó. Lugar encharcado de ancestralidade. Nele, acontecia outra alquimia, a transformação recíproca. Nele, podia criar ao ser criada. Exercia minha liberdade. Experimentava múltiplos caminhos. Tudo isso, sem sair dali.

Cada aluno trazia inúmeras possibilidades de embarcar numa viagem. Seja pela saga dos conteúdos. Seja pela saga da convivência. Desenvolvíamos nossos vínculos afetivos a partir de nossas histórias. Do caos gerado pela imagem de um pequeno quarto repleto de um mobiliário adaptado, dos livros empilhados por todos os lados, como fonte de consulta, além de materiais escolares diversos, a proximidade dos aromas e dos sons da casa, as vibrações e distrações do quintal. Era nesse caos que ludicamente experimentava criar uma nova ordem. Compartilhando insights. Momentos de cosmos. Não me dava conta da potência da poiésis que me visitava em cada um deles. $\mathrm{O}$ espaço doméstico engendrava uma poética.

Outro lugar importante foi a escola estadual na qual estudei o ensino fundamental e médio. Estudei doze anos nela. E ao término do magistério não queria parar de estudar. Sabia da importância de cursar uma faculdade para ter uma profissão e também porque meu desejo em continuar estudando mantinha acesa a chama de me reconhecer necessária no mundo.

Contudo, a condição financeira de minha família, não permitia cursar uma faculdade particular, e nesta ocasião, em 1993, passei a ser arrimo de família, pois meu pai estava aguardando o benefício de sua aposentadoria sem estar empregado. Minha irmã já tinha se casado e minha mãe não estava trabalhando e tinha uma saúde frágil.

Foi quando usei todos os métodos autodidatas que conhecia para estudar para o vestibular. Escolhi como carreira a Pedagogia. Sonhava em ter uma escola e me estabelecer como professora. Ser a mulher independente tão admirada pela minha mãe para ajudá-la a conquistar seus projetos, por exemplo, reformando nossa casa, participando de múltiplos processos de transformação: dos futuros hipotéticos alunos, de nossa família, de nossa condição material e de minha saga.

E assim, cheguei à segunda fase do FUVEST e na quarta chamada conquistei meu sonho. Iniciava em março de 1994 no curso de Pedagogia da FEUSP a carreira que escolhi, talvez sem me dar conta, que era ela que tinha me escolhido.

Nunca tinha estado antes na FEUSP. Quando vi meu nome na quarta lista de chamada e efetivei minha matrícula, foi algo catártico. Um desses momentos de bem-aventurança inesquecíveis. Puro amor fati. 
Ainda trabalhava com as aulas particulares e também como secretária numa escola de educação infantil da rede municipal. Não era um cargo concursado. Passei por uma prova e fui aprovada pelo Conselho de Escola. Como comecei mais tarde que a turma de Pedagogia - pois estava na espera da vaga de uma milagrosa desistência - tive que me esforçar muito para recuperar o tempo perdido. Foi um período muito intenso. Mas como já disse o poeta, Renato Russo: "disciplina é liberdade, compaixão é fortaleza, ter bondade é ter coragem". Lembro ter emagrecido sete quilos em dois meses. Aos poucos, fui me adaptando ao desafio de sair daquele meu pequeno mundo conhecido.

Outra memória inesquecível foi minha primeira aula. Minha primeira professora no curso de Pedagogia, foi quem num futuro próximo, me convidaria para eu ser sua bolsista de Iniciação Científica pelo CNPq e também, posteriormente, foi minha orientadora no mestrado: a doutora Maria do Rosário Silveira Porto, minha querida Rosinha, como nós alunos, sempre a chamamos. Também foi na última aula desta disciplina que conheci aquele que seria após alguns anos, meu marido. Estava iniciando minhas leituras acerca da Mitologia Grega e conheci aquele que tinha realizado os doze trabalhos. Mas o fato, é que a força de seu nome compôs o enredo de nossas histórias até o momento em que nos separamos. Ele era estudante do curso de Matemática no IMEUSP e realizava sua licenciatura na FEUSP, onde nos conhecemos.

Durante os quatro anos, como estudante de Pedagogia, fui vencendo meus medos, todas as vezes que não me sentia capacitada para as situações. Paralelamente, iniciei minha carreira na rede pública estadual como professora, onde também encontrei novos desafios. Aprendi a administrar meu tempo e a lidar com as situações novas. Fui contratada para ministrar aulas de Língua Portuguesa nas turmas de sétimas e oitavas séries do ensino fundamental e segundos anos do ensino médio. Novamente, mergulhei nos métodos autodidatas. Além de estudar o conteúdo, tinha outro desafio: estar à frente de salas com mais de trinta alunos que tinham em sua maioria - praticamente a mesma idade que eu.

Conquistar o respeito destes alunos foi uma jornada gradual, lenta e árdua. E me lembrar de experiências significativas vividas como aluna me ajudaram a construir um caminho metodológico, nos quais o teatro, a música, a dança e a poesia foram os meios de aproximação com estes alunos.

Na FEUSP, um dos temas que me despertaram para esta aproximação, foi o trabalho com as histórias de vida. Convidei os alunos a escreverem seus diários. Os incentivava a escreverem sobre seus projetos. Eles dramatizavam cenas destes diários escolhidas em grupos, além de 
escreverem seus textos, escolherem e confeccionarem seus cenários, figurinos, coreografias e sonoplastia.

Ao término do ano de 1994, vivi mais uma experiência de bem-aventurança por não ter desistido desta aventura. Tive momentos de medo, insegurança, derrota, sofrimento, desafio, identificação, curiosidade, respeito e realização. Ritos de passagem e de iniciação, em cadência entre sístoles e diástoles. Respiração intensa, às vezes ofegante, mas a chama da vela, que embora queimasse intensamente a cera do meu corpo, fortalecia a minha alma. Ao tomar meu trabalho era tomada por ele. Ao compartilhar os projetos de vida de meus alunos, eram eles que escreviam a minha história. As suas resistências erguiam-se como o espelho das minhas inquietações, por querer oferecer a eles uma educação de qualidade, para que pudessem lutar por suas vidas com igualdade de condições. E me reconhecer frágil nesse processo.

Talvez me inquietasse ver a história se repetindo. A luta quase heróica para se ter um mínimo de igualdade de condições. Ver que cada um daqueles jovens merecia uma escola melhor, um país melhor, um mundo melhor, tanto quanto eu também merecia.

Era a minha utopia quase juvenil unida com a deles. Então superando os nós da convivência, nos tornamos nós em nossa experiência, talvez numinosa.

Estava dando meus primeiros passos como professora, bolsista e namorada. Inícios cruzados no trajeto antropológico de me constituir pessoa, também nos tropeços, nos medos, dúvidas, incertezas e indignações.

Nossos diários tinham em comum, amores platônicos, a crença num mundo melhor e o repúdio à corrupção. E quem poderia cantar melhor a nossa voz, tratando destes temas do que o "Legião Urbana" na composição do poeta que era e sempre será, meu porta-voz: Renato Russo. O dilema de se tornar pessoa - aquele que afronta com sua presença, que ressoa no mais íntimo de si mesmo, como construção cotidiana, provisória e paradoxal, que se dá no embate entre a pulsão subjetiva em sua vontade de transcendência e a resistência concreta do mundo em sua facticidade, opacidade aos nossos desejos e vontades - dito de outra forma poderia ser nas palavras de Fernando Pessoa, Renato Russo e daquela que narra, os versos que seguem:

\section{Poema em linha reta Fernando Pessoa (Álvaro de Campos)}

Nunca conheci quem tivesse levado porrada. Todos os meus conhecidos têm sido campeões em tudo. 
E eu, tantas vezes reles, tantas vezes porco, tantas vezes vil, Eu tantas vezes irrespondivelmente parasita, Indesculpavelmente sujo,

Eu, que tantas vezes não tenho tido paciência para tomar banho,

Eu, que tantas vezes tenho sido ridículo, absurdo, Que tenho enrolado os pés publicamente nos tapetes das etiquetas,

Que tenho sido grotesco, mesquinho, submisso e arrogante,

Que tenho sofrido enxovalhos e calado,

Que quando não tenho calado, tenho sido mais ridículo ainda;

Eu, que tenho sido cômico às criadas de hotel,

Eu, que tenho sentido o piscar de olhos dos moços de fretes, Eu, que tenho feito vergonhas financeiras, pedido emprestado sem pagar,

Eu, que, quando a hora do soco surgiu, me tenho agachado

Para fora da possibilidade do soco;

Eu, que tenho sofrido a angústia das pequenas coisas ridículas,

Eu verifico que não tenho par nisto tudo neste mundo.

Toda a gente que eu conheço e que fala comigo

Nunca teve um ato ridículo, nunca sofreu enxovalho, Nunca foi senão príncipe - todos eles príncipes - na vida...

Quem me dera ouvir de alguém a voz humana

Que confessasse não um pecado, mas uma infâmia;

Que contasse, não uma violência, mas uma cobardia!

Não, são todos o Ideal, se os ouço e me falam.

Quem há neste largo mundo que me confesse que uma vez foi vil?

Ó príncipes, meus irmãos,

Arre, estou farto de semideuses!

Onde é que há gente no mundo?

Então sou só eu que é vil e errôneo nesta terra?

Poderão as mulheres não os terem amado,

Podem ter sido traídos - mas ridículos nunca!

E eu, que tenho sido ridículo sem ter sido traído, Como posso eu falar com os meus superiores sem titubear?

$E u$, que venho sido vil, literalmente vil,

Vil no sentido mesquinho e infame da vileza.

(Dado Villa-Lobos / Renato Russo / Marcelo Bonfá)

Tire suas mãos de mim

Eu não pertenço a você

Não é me dominando assim

Que você vai me entender

Eu posso estar sozinho

Mas eu sei muito bem aonde estou

Você pode até duvidar

Acho que isso não é amor 
Será só imaginação?

Será que nada vai acontecer?

Será que é tudo isso em vão?

Será que vamos conseguir vencer?

Nos perderemos entre monstros

Da nossa própria criação?

Serão noites inteiras

Talvez por medo da escuridão

Ficaremos acordados Imaginando alguma solução

Pra que esse nosso egoísmo

Não destrua nosso coração

Será só imaginação?

Será que nada vai acontecer?

Será que é tudo isso em vão?

Será que vamos conseguir vencer?

Brigar pra quê

Se é sem querer

Quem é que vai nos proteger?

Será que vamos ter

Que responder

Pelos erros a mais

Eu e você?

Neste trajeto sempre constante entre as pulsões interiores e as demandas do mundo, o caminho vai sendo delineado para além do mistério.

Nas palavras de Morin:

A plena consciência da incerteza, da eventualidade, da tragédia em todas as suas coisas humanas está longe de me ter conduzido ao desespero. Ao contrário, é estimulante trocar a certeza mental pelo risco, já que, assim, se ganha a chance. As verdades polifônicas da complexidade exaltam, e serei compreendido por aqueles que, como eu, se asfixiam no pensamento fechado, na ciência fechada, nas verdades limitadas, amputadas, arrogantes. É estimulante arrancar-se para sempre da palavra-mestra que explica tudo, da ladainha que pretende tudo resolver. É estimulante, enfim, considerar o mundo, a vida do homem, o conhecimento, a ação como sistemas abertos ${ }^{82}$.

Como o autor, entendo que seja necessário considerarmos o mundo, a vida, o homem, o conhecimento e a ação como sistemas abertos, inacabados e complexos. E ao reconhecermos a

\footnotetext{
${ }^{82}$ Morin, 1975, p.88.
} 
incerteza, a eventualidade e a tragédia como integrantes da vida, passamos a não ser indiferentes a ela.

Sentimos a vida em cada instante de leveza, percebendo as novas marcas deixadas pelo tempo em nossa face e em nosso coração.

Ao reconhecermos que nossa vida não possui um curso previsível, que não convivemos com pessoas ideais, mas concretas e, portanto, complexas, que somos contraditórios e errantes, estamos falando da existência da complexidade em nossas relações com o mundo.

Sendo professora, vivi muitos momentos de desafio, arriscando caminhos novos para chegar aos alunos. Neste percurso, percebia contradições entre o que estudava no curso de Pedagogia e a minha realidade cotidiana. Realidade repleta de questionamentos para os quais não existiam respostas prontas ou soluções acabadas.

Foi nesta prática diária que passei a gostar de educação. Não desistindo de buscar novas metodologias de trabalho para alcançar meus objetivos como professora, fui descobrindo a virtude do cotidiano. Caminhos cruzados no cotidiano da sala de aula cercados por uma instituição repleta de códigos, normas e legislações. Mas também repleta de ritmos, gestos, sons, desejos e expressões.

A respeito do sentido da educação, podemos dizer que a partir dela é possível trazer para fora a humanidade potencial que há nas pessoas (humanitas) desde nossa infância.

Sobre este sentido, podemos refletir com Fétizon que:

Formalmente, entendo que a educação é o processo e o mecanismo da construção da humanidade do indivíduo, ou da pessoa (como preferirem). Enquanto processo, a educação é pertença do indivíduo (ou da pessoa), isto é,

é o processo pelo qual, a partir de seu próprio equipamento pessoal (biofiosiológico/psicológico) cada indivíduo se autoconstrói como homem. Enquanto mecanismo, a educação é pertença do grupo - é o recurso (ou o instrumento) que o grupo humano - e só ele - possui, para promover a autoconstrução de seus membros em humanidade (ou como homens). Se falo em construção, em autoconstrução de humanidade como "dada", ou "gratuita" - ou seja, não suponho que o simples fato de havermos nascido como membros da espécie humana nos garanta que nos desempenhemos humanamente ${ }^{83}$.

Na mesma direção enfatizando o caráter dialógico deste processo, nos afirma Ferreira-Santos \& Almeida:

${ }^{83}$ Fétizon, 2002, p. 103 
Todo processo educativo, nessa perspectiva do humanitas, é um processo que visa trazer à tona o mais específico da pessoa: fazer com que ela seja ela mesma. Tarefa impossível sem preâmbulo dialógico. Tarefa impensável sem uma paixão pelo humano, que é ponto de partida. Tarefa irrealizável sem o cumprimento de um destino comum: paixão pelo saber... philo-sophia, diriam os gregos. Mas esse saber feminino, caracterizado pela sophia, não é um conhecimento instrumental que utiliza, independentemente, da própria pessoa e em relações de poder de dominação. Todo ao contrário, como já ressaltado por vários pensadores, é um saber-sabor que remonta à arqueologia culinária da cognição para cozer o alimento, depurá-lo, temperá-lo, transformá-lo, apropriar-se dele... Para quê? Para compartilhar na mesa da amizade. Podemos educar eruditos. No entanto, educar é um verbo que somente pode ser conjugado reflexivamente. Portanto, educar-se já é um ato sábio, pois o que se sabe foi aprendido na convivência com outro sábio ou sábia. Os sábios e sábias engendram-se ${ }^{84}$.

Levados pelo agitado ritmo imposto pelo nosso dia-a-dia, nós professores, nem sempre temos oportunidade de refletir sobre nossa prática e sobre o quanto a mesma pode ser ou não significativa. Nem sempre temos a oportunidade de refletir sobre até que ponto nós estamos satisfeitos com a nossa atuação e de como poderíamos nos aventurar para recriá-la.

Transformando o percurso em palavras, ao narrar minha memória, é que pude religar os fios como tecelã. Reconhecendo na imagem do parteiro de si e do outro, a atuação pedagógica.

Foi pela aventura do conhecimento que cheguei ao curso de Pedagogia, motivada por meus sonhos e minhas experiências na escola pública e pela minha experiência como artesã e parteira, durante o trabalho como preceptora nas aulas de reforço.

Imergir na aventura da jornada, pelos itinerários de formação me levou a investigar meu próprio processo de formação. Tal imersão ocorreu quando tive oportunidade de participar como bolsista de Iniciação Científica do projeto Integrado de Pesquisa: Imaginário e Cultura Escolar Brasileira: A Produção de Textos na e sobre a escola ${ }^{85}$, mais especificamente, investigando o imaginário dos alunos da FEUSP, a partir de suas produções orais e escritas.

Neste projeto, minha atuação enquanto bolsista consistiu na análise das produções dos alunos no sentido de observar o processo de formação de futuros educadores ao incorporarem (ou não) em seu ideário e imaginário (do patente ao latente) os valores veiculados no discurso pedagógico vigente naquela instituição.

\footnotetext{
${ }^{84} 2011$, p. 20

85 Paula Carvalho, 1998b.
} 
Com isso, destaco minha condição de sujeito e objeto de pesquisa, naquele contexto, à medida que percorri minhas próprias impressões de aluna da FEUSP. Este caminho de dentro para fora e de fora para dentro, permitiu-me uma revisão paradigmática ao conhecer novos caminhos de pesquisa, apoiados na investigação sobre o imaginário como faculdade essencial do pensamento e da ação.

Assim, ao conversar com colegas nos corredores, na lanchonete, aplicando e interpretando questionários e entrevistas ou lendo as suas histórias de vida, que tive a oportunidade de conhecer a dimensão mítica do discurso feuspiano.

Tal reflexão permitiu-me compreender as organizações educativas a partir de outro paradigma, no qual se admite a complexidade das relações humanas, reconhecendo a importância do imaginário no cotidiano.

A partir desta encruzilhada antropológica que conheci a área temática: Cultura, Organização e Educação e reconheci a complexa teia que permeia as relações humanas por meio da cultura que ao tecer o homem é transformada por ele, dinamicamente.

Nesta área temática, conheci a Culturanálise de Grupos, proposta pelo professor José Carlos de Paula Carvalho, as investigações do imaginário de Gilbert Durand e a Antropologia da Complexidade de Edgar Morin. Passei a conhecer e participar das ações do CICE/FEUSP: Centro de Estudos sobre Imaginário, Culturanálise de Grupos e Educação, na forma de congressos, seminários e defesas de mestrados e doutorados na área.

Considerando as contribuições desta linha teórica, passei a refletir sobre a complexidade das organizações educativas, especialmente a da escola.

Abordando as implicações do referencial teórico sobre a pesquisa das organizações educativas, principalmente a da escola, Silveira Porto ${ }^{86}$ observa a necessidade de um outro olhar, que privilegie não apenas aspectos estruturais como uma organização burocrática ou a funções sócio-políticas que porventura assumam, mas sobretudo as manifestações da dimensão simbólica, imaginária e as práticas simbólicas organizadoras do real, aquilo que M. Maffesolli denomina o lado de sombra do social - o cotidiano do grupo, os conflitos, os rituais, os espaços intersticiais -, conhecimento fundamental para entender como os grupos compreendem seu real social e como agem em função dessa compreensão.

Para dar conta da complexificação constante do ser e da existência humana, é necessária uma reparadigmatização, uma mudança de olhar, que permita perceber os múltiplos e pequenos fenômenos que ocorrem nos sistemas antropossociais e que possa abrir caminho para uma

${ }^{86} 2000$, p.18 
comunicação-elaboração transdisciplinar oposta ao isolamento racionalizante, reintroduzindo o sujeito como interventor e produtor do real. Esses paradigmas que estão emergindo ("da complexidade" para E. Morin; "holonômico" para Paula Carvalho) têm como características, no campo do conhecimento científico, entre outras, a percepção da limitação do conhecimento; a aceitação de resultados aproximados, baseados do caráter probabilístico, aproximativo e provisório das leis; a inviabilidade do determinismo mecanicista; a ideia de que a totalidade do real não se reduz à soma das partes; a distinção sujeito-objeto, que perde seus contornos dicotômicos e assume a forma de um continuum. Os novos paradigmas baseiam-se numa "razão aberta", dialógica, que postula outra lógica, não binária, a qual, em vez de tentar eliminar a incerteza, a ambiguidade, a diferença, trabalha com elas. No campo dos estudos sociais e humanísticos, pretendem uma visão complexa e global da sociedade, ao considerar o que é rejeitado como "resíduos" irracionais ou não racionais, elementos que, de acordo com Morin ${ }^{87}$, antes de serem desintegradores, interagem e reorganizam o sistema, a partir de uma relação recursiva, que se caracteriza por aceitar o antagonismo, a complexidade e a contraditoriedade, ou seja, as múltiplas e pequenas ocorrências do cotidiano dos grupos e das organizações sociais, ignoradas ou desconsideradas pelas teorias "clássicas" como alienantes ou alienadas, que são entretanto, resultantes das relações inter e intragrupais. ${ }^{88}$

A partir dos estudos deste referencial teórico metodológico e de minha participação no projeto integrado de pesquisa, como bolsista, que me envolvi com um novo projeto - o mestrado - , movida por meu desejo: de investigar o ingresso profissional de uma aluna da FEUSP numa escola da rede pública municipal de São Paulo, isto é, investigar a organizacionalidade da escola na qual trabalhava. Colocava-me novamente nesta fecunda e conflituosa condição de sujeitoobjeto, desta vez estudando o meu curso, discurso e percurso como professora.

Iniciei na rede municipal de São Paulo em 1997, após ter sido aprovada em concurso público como professora alfabetizadora de uma primeira série. Passei por um novo processo de adaptação, pois teria que trabalhar com uma nova faixa etária, em outra rede de ensino, tendo agora como foco de atuação: a alfabetização.

Outro intenso início. Morte e renascimento. Encerrava minha experiência na rede pública estadual, na qual havia sido aluna e professora. Admiti a fragilidade do plano de carreira para o pedagogo na rede estadual o que me motivou prestar concurso público para ingressar na rede municipal.

\footnotetext{
${ }^{87}$ Morin, 1980, p. 16

${ }^{88}$ Morin, 2000, p. 20
} 
Desta forma, ao ingressar na rede pública municipal como professora titular efetiva, atuando como alfabetizadora no ciclo inicial do ensino fundamental, me deparei com outros questionamentos, à medida que necessitava decifrar uma nova cultura, sentindo-me um neóteno-neguentropo numa organização desconhecida que se modificava ao modificar-me. Segundo Paula Carvalho:

O homem é um neóteno neg-entropo, isto é, um ser aberto para o mundo, um especialista da não especialização, um ser permanentemente incompleto e inacabado, portanto, um ser do perigo, da álea, do risco, da desordem complexificante ${ }^{89}$.

Para Paula Carvalho acerca da do conceito de neotenia o contextualiza:

Observando que em biologia, trata-se da persistência, temporária ou permanente, das forças larvares no curso do desenvolvimento de um organismo. Os etólogos mostram que, no curso de vida desse "especialista na não especialização", que é o homem, persistem traços - Gehlen, Lorenz, posteriormente, Winnicott e Lapassade, elencam: abertura para o mundo, curiosidade ativa, ludismo, comportamento transicional e espaço potencial, incompletude e inacabamento, metamorfose, proteimorfismo, ambivalência, ambiguidade, crise, neg-entropia - que, propriamente numa polarização de difícil equilíbrio com as ritualizações filético-culturais, sobretudo no embate contra a "pseudo-especiação". (...) No sentido de uma antropolítica do neóteno neg-entropo, antropolítica do "trickster" (...) Figuras míticas do movimento permanente e da complexificação através da sombra coletiva da ordem. Haveria, assim, uma educação e uma organização pela/para a transgressão" 90 .

Precisava assim, investigar este processo de comutação para revestir minha prática docente de um novo significado, tendo em vista que tal prática escolar - reconhecida como prática simbólica - poderia ser um precioso campo de investigação.

Realizei a pesquisa na escola que trabalhava - a "escola Labirinto" como anunciado no título da dissertação do mestrado: "Trilhando pelo Labirinto: Uma Incursão Antropológica à Latência de uma Escola Municipal". Pretendia não apenas levantar os aspectos estruturais desta organização burocrática ou de suas funções sócio-políticas (lado iluminado/consciente), mas de sobremaneira, investigar as manifestações de sua dimensão simbólica (imaginária) e dos grupos que agem em seu interior (lado de sombra/inconsciente) - e a minha própria ação nestes grupos. Considerei a abordagem antropológica como meio de investigar as relações intra e

\footnotetext{
89 Paula Carvalho, 1988, p. 183.

90 Paula Carvalho, 1990, p. 215
} 
intersubjetivas de um grupo do qual fazia parte. A pesquisa sobre o imaginário escolar observava e participava da dimensão arquetípica-biológica-cultural expressa nos gestos, nos ritos e na corporeidade (sua base fluida ou mesmo seu plasma existencial).

Tal proposta indicou a importância do imaginário como uma das dimensões da realidade, apontando consequentemente, a necessidade de se debruçar sobre tais referências, no sentido de compreender mais fecundamente as relações do homem em seu grupo, e de, sobretudo, reconhecer no homem um grupo que se transforma e se conserva por seus arquétipos, que se encontram ancorados nas próprias entranhas, assim como a cultura que o tece, ao ser feita por ele.

Foi desta malha viva do cotidiano que emergiu o meu desejo de investigar a organizacionalidade escolar, considerando as marcas por ela deixadas em meu ser, ao mesmo tempo em que a marcava com a minha existência.

Acrescida ao desejo veio a indignação, ao me deparar com discursos que ora comparavam o professor a um vilão e ora o reduziam à condição de vítima, um mero reprodutor da cultura dominante.

Ao longo da minha formação tive contato com muitos textos que, ao abordarem a situação de nossas escolas, transmitiam-me a impressão de que seus autores nunca vivenciaram as múltiplas relações estabelecidas em seu interior, buscando uma explicação que a tudo procurava responder, formatando o mundo segundo uma visão racionalista, da qual se excluem o imprevisível, a álea e a inconstância tão presentes em nossas escolas.

Essa insatisfação eclodiu como explicitei anteriormente, quando era estudante de Pedagogia e professora na rede pública de ensino, onde vivenciava, como docente, uma multiplicidade de eventos e de incertezas, que, por sua complexidade, seriam irredutíveis a um único modelo explicativo.

Tal complexidade convidou-me a reconhecer a pluralidade de realidades existentes em nosso cotidiano e da necessidade de um olhar diferente, anunciador de uma abordagem mais envolvida com o interior da escola, para além de seus códigos formais e normas de funcionamento. Um outro olhar que buscasse transcender a aparência rumo à essência, reconhecendo no professor a sua condição de ser errante, aquele que trilha no jogo da incerteza, que não é nem vilão, nem vítima, mas um ser complexo, datado e marcado por sua cultura.

Assim, em 1998, decidi desenvolver o trabalho de mestrado, envolvendo-me profundamente na rotina escolar. Tinha interesse em participar da maior parte de suas atividades, conhecer 
melhor as pessoas com quem compartilhava, além do espaço, um tempo precioso de nossas vidas. Ouvindo as histórias em meio aos cafezinhos e às horas de estudo, fui construindo minha reflexão sobre o percurso. Fui investigando o cotidiano em seus aspectos simbólicos, a partir da cultura latente, seu lado instituinte, ou seja, os discursos e manifestações da dimensão simbólica do grupo, seu plasma existencial.

A este respeito Maffesolli afirma:

Existir o lado iluminado, o econômico, em todos os sentidos do termo, da existência, o qual constitui o objeto da investigação dos especialistas em planejamento ou perspectiva, e existe um lado de sombra, escondido, feito de múltiplas e minúsculas situações práticas, que é o lugar da conservação de cada indivíduo e da espécie ${ }^{91}$.

Complementando Maffesolli, ressaltamos a contribuição de Paula Carvalho ${ }^{92}$ ao entender que a cultura de uma escola tem por um lado tudo aquilo que é instituído: os códigos e modelos de ação, as normas, os padrões de comportamento social; e por outro, tudo o que é instituinte, ou seja que está latente, e ainda, não se integrou aos padrões da vida cotidiana.

Ao longo da pesquisa realizei entrevistas (alunos, professores e gestores), apliquei questionários, fotografei momentos e espaços. Propus ao grupo de professores a vivência de algumas oficinas em nosso horário de estudo. Em cada uma dessas vivências, emergia o imaginário do grupo do qual fazia parte. Um universo de angústia eclodiu dessas imagens.

Como disse, vivendo o cotidiano escolar passei a considerar a possibilidade de propor uma incursão ao plasma existencial. Isto significa: estudar a anti-história que corre paralelamente à história oficial por meio de uma Pedagogia da Escuta.

O outro olhar e a nova escuta buscariam desvelar, no cotidiano escolar, a sua duplicidade, a sua astúcia e solidariedade, como sendo constituintes desta real trama da vida, aceitando-a em sua trágica beleza. Ali, no curso da vida: quem seriam os professores? Como seriam as suas histórias? Suas metas? Suas preferências e seus medos?

Passei a escutar o grupo de professores considerando a fragmentação do tempo, a dissimulação, a participação e a resistência que constituíam a socialidade do grupo. Para Guimarães:

A socialidade, fundamenta-se nos diversos papéis que cada pessoa representa não só, por exemplo, na sua atividade profissional, mas também no seio das diversas tribos. Aqui, o

\footnotetext{
91 Maffesoli, 1984, p. 66.

92 Paula Carvalho, 1994, p. 53.
} 
pessoal não segue o princípio da individuação, que tem por referência o indivíduo particular, mas se expressa no que Maffesoli denomina corpo coletivo, sedimentado no pluralismo existencial cuja lógica tem como características a vaguidade, a indecisão, o provisório, o fluido, abrindo uma outra compreensão da cultura ${ }^{93}$.

Na experiência do mestrado, vivenciei o cotidiano do grupo para além do formalismo e do dever-ser, isto é, da dimensão técnica do discurso, passando a buscar o sonho, o imaginário enquanto mediadores simbólicos, na circulação entre o patente e o latente. Buscava, assim, imergir no corpo coletivo do grupo de professores.

Considerando as contribuições de Michel Maffesoli ao estudar o cotidiano, passei a buscar um instrumento de investigação social que utilizasse, ao mesmo tempo, a lucidez crítica e o sonho, ou a poesia - expressões de Maffesoli - indo ao encontro do conhecimento possível.

Para Maffesoli:

Encontramos nas instituições a lógica do dever-ser, na qual o domínio das regras e das normas tenta homogeneizar os comportamentos das pessoas. Mas, não podemos deixar de perceber uma lógica do querer-viver, abrindo espaço para a comunicação de cada um, para além das regras do jogo institucional ${ }^{94}$.

Do patente ao latente, a experiência cotidiana permitiu-me reconhecer as manifestações do poder e da potência na organização escolar. Assim enquanto o poder homogeneiza, dita o dever-ser:

A potência é uma pulsão, que se expressa em todos os níveis da existência individual e social, é um modo de exprimir a cristalização do coletivo - em outras palavras, o simbólico. Enquanto a lógica do poder é a dominação, a redução ao uno, a potência conduz ao pluralismo, a diversidade do real que constitui a vida social em sua labilidade ${ }^{95}$.

Pulsando cotidianamente com esta potência fui me conhecendo melhor junto com meus colegas de profissão. Aos poucos, em cada situação fui percebendo as brechas para criar outras formas de investigação.

Nesse processo de investigação e convivência, ao longo da primavera de 1999, propus o projeto Delphys, que se caracterizava por encontros que aconteciam durante os horários de estudo no

\footnotetext{
${ }^{93}$ Guimarães, 1996, p. 75.

${ }^{94}$ Maffesoli, 1984, p. 66-7

${ }_{95}$ Maffesoli, 1981, p. 51
} 
grupo de formação continuada ${ }^{96}$ do qual fazia parte. Estes encontros teriam como seu fio condutor (fio de Ariadne, a senhora do labirinto) as nossas histórias, considerando a iniciação ao mundo escolar desde a infância, a importância do brincar e a importância das famílias em nosso processo de formação, a partir não apenas de entrevistas e questionários, mas também de vivências utilizando músicas, apreciação de imagens, desenho, pintura, reflexões sobre o processo de identificação com símbolos e imagens e a tematização de nossos medos e angústias.

Delphys, a matriz, surgiu assim, no diálogo entre a desordem e a ordem, quando no início era apenas o caos, o turbilhão de ideias e imagens.

Na dissertação do mestrado, comparo o projeto Delphys a um embrião ligado ao significado da primavera. A origem da escolha do projeto está relacionada à referência do útero, como matriz de representações do grupo. Para Chevalier:

O simbolismo do útero ou matriz está universalmente ligado à manifestação, à fecundidade da natureza e à regeneração espiritual. A mitologia está cheia de mitos da Mãe Terra, homóloga da matriz, dos mundos subterrâneos, das cavernas e dos precipícios. Lembra, Mircea Eliade, que a significação de Delphys (matriz) à qual o local de Delfos deve seu nome. Em outras regiões, se diz que os recursos se originam da matriz terrestre. As minas são também matrizes, de onde se extrai, por métodos associados à obstetrícia, os minerais, embriões que ali amadureceram. Também as pedras preciosas crescem, segundo a tradição da Índia, dentro do rochedo como uma matriz ${ }^{97}$.

Acredito que Delphys tenha sido uma experiência inicial de pesquisa, que trouxe uma oportunidade de aprofundamento em minha formação como pessoa, e claro, também como profissional. A partir dele, reconheci a potência subterrânea do imaginário, seja na expressão de um universo de angústia ou de sua força regeneradora a partir do prazer de estarmos juntos, de nossa proxemia.

Do homem à humanidade, da ontogênese à filogênese, a cultura é a trajetividade na qual se configura a organizacionalidade profunda que se cristaliza nas organizações sociais. É nessa trajetividade/circuito que se pode aprender os aspectos da cultura de um grupo

\footnotetext{
${ }^{96}$ As jornadas de trabalho dos professores na Prefeitura Municipal de São Paulo são compostas de uma carga horária que além da regência podem ter um horário de estudo coletivo, dependendo da opção de cada professor. Neste horário desenvolvem-se leituras e vivências que estejam em conformidade ao Projeto Político Pedagógico da escola, tendo como orientador o Projeto Especial de Ação (PEA) elaborado anualmente para atender as demandas formativas do grupo. Em cada administração, as legislações que definem o perfil do projeto são atualizadas a partir de Portarias próprias, publicadas no Diário Oficial da Cidade.

97 1999, p. 599
} 
social, como: algo mais do que uma reunião de indivíduos, mas como uma comunidade de ideias, preocupações impessoais, estabilidade da estrutura que supera as particularidades dos indivíduos - que se fundamenta no sentido partilhado; (...) ० fato de partilhar um hábito, uma ideologia, um ideal determina o estar junto e permite que este seja uma proteção contra a imposição. A partilha secreta do afeto, ao mesmo tempo em que confirma os laços próximos, permite resistir às tentativas de uniformização ${ }^{98}$.

Segundo Paula Carvalho:

A cultura como metabolismo ou circuito metabólico refere-se à produção de sentido; metabolismo entre o domínio dos epifenômenos ou onirismo imaginário e dispositivo generativo da sociedade (bases da organização social). A linguagem metabólica consiste como figura de linguagem, na repetição de uma ideia em termos diferentes, ou seja, é simultaneamente repetitiva e diferencial. A metábole e metalepse (guiada pela intencionalidade do desejo, a sincronia presente) são o próprio estilo do mito ${ }^{99}$.

Vivi dez anos de muita intensidade pessoal e profissional, longe da reflexão acadêmica, mantendo latentes as implicações destas experiências.

Durante o período de 2002 a 2012, pouco acompanhei os eventos da área temática de Cultura, Organização e Educação. Passei por grandes mudanças em minha vida. Em termos profissionais, passei a me dedicar integralmente à carreira na rede municipal de ensino.

Continuei atuando em sala de aula, acumulando com o cargo de coordenadora pedagógica até o ano de 2005.

No período de fevereiro de 2002 à dezembro de 2005, trabalhava uma média de quatorze horas diárias, acumulando as duas atuações, em escolas de ensino fundamental, situadas na zona sul de São Paulo, na região de Campo Limpo.

A partir de 2006, passei a atuar apenas num cargo, correspondente à coordenação pedagógica, quando iniciei minha primeira experiência como formadora na Divisão de Orientação TécnicoPedagógica na Coordenadoria de Educação de Campo Limpo. Pedi exoneração do cargo de professora titular de ensino fundamental, com o objetivo de melhorar minha qualidade de vida e investir mais atenção ao meu casamento.

Em termos pessoais, em 2000, vivi a perda de minha mãe. No mesmo ano, acompanhei a superação de um sério problema de saúde de meu pai.

\footnotetext{
98 Maffesoli, 1987, p. 112

${ }^{99}$ Paula Carvalho, 1990, p. 214
} 
Casei-me em fevereiro de 2001. Passei por vários desafios de adaptação ao transitar por estas mudanças. Paralelamente, participei de forma ativa de todo o processo de aquisição de minha nova casa, desde o seu financiamento, passando pela reforma e pela mudança. Tratei de todos os detalhes do casamento, tanto no civil quanto do religioso. Momentos de alegria, conquista, ansiedade, mesclados à dor da perda. Foi um período muito intenso, de emoções muito contraditórias.

O desafio do Labirinto continuava. E o foco da viagem para o centro do meu próprio interior, uma necessidade cada vez mais presente. Permaneci nele, mesmo tendo finalizado o ciclo da pesquisa. Constituí vínculos de amizade e de pertencimento muito significativos. Senti uma grande falta desta convivência, quando optei pela carreira de gestora.

Em 2002, ao iniciar minha atuação na coordenação pedagógica, ainda tive que acumular os cargos para compor a renda familiar, para honrar com os compromissos assumidos financeiramente. $O$ período de acúmulo de cargos, também me possibilitou experimentar os desafios da gestão. Desafios para o quais precisava ter uma dedicação maior, em termos de carga horária e do exercício do papel de gestor na rede pública educacional. Trabalhei na escola Labirinto até o fim de 2005, ano no qual optei pelo cargo de coordenadora pedagógica. A fome da alma se aprofundava... 


\section{O Vôo da Fênix:}

\section{A Experiência como Coordenadora Pedagógica e como Formadora de Educadores}

Nos diversos percursos que constituem a trama dos saberes, a cultura nos produz como sujeitos em nosso tempo efêmero, em espaços diversos que ora nos afastam, ora nos aproximam.

Somos o produto do que produzimos num breve instante. Pelo percurso da vida, são as perguntas que alimentam nosso desejo humano da criação. A criação que dá sentido para estarmos neste mundo, refletindo sobre o seu curso à medida que caminhamos.

As perguntas que mobilizaram o meu percurso na educação sempre estiveram relacionadas a uma busca pelos processos formativos dos educadores.

Desde a graduação no curso de Pedagogia da FEUSP, quando já era bolsista de iniciação científica pelo CNPq, investiguei os mitos presentes nos discursos dos pedagogos em formação, isto é, o meu próprio discurso e universo de imagens. No mestrado, era o imaginário da escola na qual trabalhava que me despertava a curiosidade em descobrir o universo de imagens daquele grupo e suas estratégias de autogestão, numa escola pública da rede municipal de São Paulo, quando então, ainda era professora.

No mesmo ano em que finalizei o mestrado iniciei minha carreira como gestora. Foi trilhando meu caminho profissional como coordenadora pedagógica na rede municipal da cidade de São Paulo que fui desafiada por novas perguntas acerca dos fazeres, especialmente quando passei a atuar na Educação Infantil, observando a diversidade cultural apresentada no corpo docente, das escolas nas quais atuei como gestora na dimensão pedagógica, propondo e coordenando a formação continuada nestes grupos.

Observando as diferentes comunidades, as diversas necessidades das crianças, as propostas de seus professores e dos demais educadores dessas escolas, que a concepção de infância revestiu-se de significado em minhas reflexões.

Afinal, ao organizarmos o trabalho de uma escola como gestores, nós lidamos com a complexa teia das relações ali estabelecidas. Relações que para além das políticas públicas e das técnicas metodológicas são mediadas pelas relações simbólicas cotidianas do ser e do fazer de cada um. 
Tratar dos projetos pedagógicos das escolas é desvelar os percursos de seus educadores, sua cultura local e instituinte. É investigar suas concepções de infância, considerando suas crenças e necessidades, como sujeitos em contínuo processo de formação profissional a partir de seus saberes e fazeres, suas representações, discursos e ações.

Em minha trajetória profissional atuei em diferentes modalidades e funções, trilhando um percurso que teve início como professora no ensino médio, fundamental e na educação infantil, e posteriormente, como coordenadora pedagógica em 2002, no mesmo ano em que concluía minha dissertação de mestrado ${ }^{100}$.

Minha primeira experiência como coordenadora pedagógica foi numa escola de ensino fundamental. Organizava os horários de estudo, fazia atendimento de professores, pais e alunos. Coordenava junto com os demais educadores, os tempos, espaços, materiais e interações.

Num primeiro momento, percebi o quanto o fato de me tornar gestora, modificou meu olhar, ampliando sua perspectiva quanto à complexidade de elementos do cotidiano. Como coordenadora, sentia a enorme responsabilidade ao buscar colaborar para a melhoria da qualidade do trabalho escolar. Um primeiro diagnóstico foi a baixa motivação de alguns alunos, que de forma recorrente apresentavam queixas disciplinares por parte dos professores.

Não tinha respostas para aqueles problemas. Conversava com os alunos, professores, com as colegas da equipe gestora e com as famílias. Ao conversar com os alunos e suas famílias fui aprendendo a não tornar estes encontros um enfrentamento. Procurava valorizar as qualidades dos alunos e, em nossa reunião, pensar conjuntamente, meios de colaborar para o seu desenvolvimento. Até que ponto, as situações consideradas indisciplinares não eram um modo de pedir atenção? Criava a partir daí meu repertório para pensar intervenções. Eu usava nas pautas algumas músicas como sensibilização. Uma delas, Pais e Filhos, de Legião Urbana. Creio que neste repertório também participaram minhas lembranças como adolescente. Meus conflitos, anseios e sonhos. E também a de meus colegas. Da mesma forma, tratava os pais dos alunos, lembrando dos meus pais, tios e vizinhos. Assim, procurava acolhê-los, ouvi-los, para então, dar a minha versão dos fatos, com as informações de que dispunha.

Pais e Filhos

(Legião Urbana)

Estátuas e cofres

E paredes pintadas

\footnotetext{
100 Fonseca, 2002.
} 
Ninguém sabe o que aconteceu Ela se jogou da janela do quinto andar Nada é fácil de entender.

Dorme agora: É só o vento lá fora.

Quero colo

Vou fugir de casa

Posso dormir aqui

Com vocês?

Estou com medo tive um pesadelo

Só vou voltar depois das três.

Meu filho vai ter

Nome de santo

Quero o nome mais bonito.

É preciso amar as pessoas

Como se não houvesse amanhã

Porque se você parar pra pensar,

Na verdade não há.

Me diz por que o céu é azul

Me explica a grande fúria do mundo São meus filhos que tomam conta de mim

Eu moro com a minha mãe Mas meu pai vem me visitar Eu moro na rua, não tenho ninguém

Eu moro em qualquer lugar Já morei em tanta casa que nem me lembro mais

Eu moro com meus pais.

Sou uma gota d'água

Sou um grão de areia

Você me diz que seus pais não entendem

Mas você não entende seus pais.

Você culpa seus pais por tudo

Isso é absurdo

São crianças como você.

O que você vai ser

Quando você crescer?.

Alguns pais e alunos se sensibilizavam com estes encontros. Quando possível, também convidava alguns professores. A intenção era humanizar os atendimentos e profundizar os vínculos.

Procurava mediar as relações entre professores e alunos, a partir de propostas que oportunizassem projetos interdisciplinares, feiras e mostras culturais. Incentivava a 
participação dos diferentes segmentos na atuação junto ao Conselho de Escola. Valorizava a participação da escola em campeonatos e saídas culturais. Acreditava na necessidade que tinham de vivenciar outras experiências, trilhando outros itinerários de formação.

Realizei o projeto "O que serei daqui a vinte e cinco anos" com as turmas das oitavas séries. Os alunos faziam redações e depois compartilhávamos em grupos. Era um modo de conhecê-los melhor. Fazia estas participações, em situações em que estavam em aulas vagas e era possível conciliar minha atuação. Era uma oportunidade de eles elaborarem suas ações motivados por seus desejos e de estabelecer uma avaliação sobre seus caminhos já trilhados, para pensarem em como alcançar o que ainda não conheciam. Sugeria que pesquisassem em revistas e outras fontes, informações que pudessem ajudá-los. Nos encontros subsequentes compartilhávamos nossas contribuições.

Foi uma experiência positiva, porém nem sempre conseguia dar continuidade ao processo da maneira como desejava, dadas as outras demandas da escola.

Outros fatores que geravam angústia era ver o número de aulas vagas, em função da falta de alguns professores, o número de professores em licença médica, a falta de oferta de professores em algumas áreas. Uma certa apatia no corpo docente na proposição de alternativas para se aproximarem dos alunos, para além do conteúdo, das provas e avaliações. Isto me trazia inúmeros questionamentos face minhas possibilidades e limites.

Este conjunto de fatores gerava uma sensação de angústia. Outra dificuldade vivenciada foi a resistência de alguns educadores e alunos no processo de convívio. Resistência manifesta por parte de alguns professores, em alguns dos episódios de "indisciplina" dos alunos, ao não gerenciarem os conflitos a partir do diálogo. Tentavam se afastar destas situações, mandando os alunos indisciplinados para a direção e/ou para a coordenação pedagógica. Lembro que este foi um desafio recorrente.

Creio que a problemática da alteridade estava posta num imbricado jogo de espelhos, que prejudicava a possibilidade da dialogicidade cotidiana. O etnocentrismo aparecia sob diversas perspectivas. E da não aceitação das diferenças erguiam-se os conflitos. A sombra do grupo. A projeção do Outro e no Outro como Sombra. Afinal, o enfrentamento da realidade era árduo para todos.

Eu também carregava a problemática do etnocentrismo sobre os ombros, pois estava me adaptando ao fato de não me reconhecer mais como porta-voz do grupo. Não era professora. Estava construindo minha identidade como coordenadora pedagógica. 
Compartilhava minhas angústias com a outra coordenadora pedagógica e com a direção. Também tive a oportunidade de aprender muito com minha parceira de coordenação. Ela era artista plástica, e por muitos anos, antes de iniciar seu trabalho na rede municipal, tinha coordenado grupos de jovens, tendo a arte como meio e finalidade de atuação. Montávamos pautas juntas. Fomos parceiras em muitas situações. Desde as mais germinais e motivadoras até as mais difíceis e perturbadoras. Buscávamos superar os desafios, reunindo-nos semanalmente, para avaliar e planejar nossas ações conjuntamente.

Incentivámos um professor de matemática da escola a desenvolver o Projeto Jogo de Xadrez. Durante as suas aulas e também compondo sua jornada para preparar os alunos interessados a organizarem um torneio. A participação da escola em campeonatos de voleibol também era fundamental. Os alunos tinham grande interesse e se envolviam nestas ações. Também incentivávamos a participação em exposições de arte e a frequência ao teatro. Passeios que organizávamos procurando envolver professores e alunos.

Lembro de situações de grande vulnerabilidade da escola. Numa delas, durante um feriado prolongado, assassinaram dois jovens na quadra da escola. Isto trouxe uma grande indignação a todos nós. Uma sensação de impotência e de medo.

Foi uma experiência difícil. Por alguns dias não tive vontade de voltar à escola. Foi neste período que iniciei algumas vivências de Delphys, nos horários de estudos nos grupos de formação. Uma delas foi a escrita das memórias das preferências dos professores. Abordaram desde as coisas que mais gostavam na escola, até aquelas que lhe causavam desconforto. Usava música new age de fundo. Algumas de Yanni, outras de Vangelis e também de Enya. Além de escrever, eles poderiam desenhar, representar e também trazerem objetos que evocassem suas memórias. Creio que a partir destas trocas humanizávamos aquele espaço, inclusive para tentarmos superar juntos os nossos medos, compartilhando nossas motivações. Foi uma experiência inicial muito rica na coordenação pedagógica. Fui desafiada a organizar pautas de formação, a coordenar a estrutura de funcionamento da escola, a gerenciar conflitos, a desenvolver um diálogo com as famílias, a buscar apoio da supervisão escolar. Também aprendi procedimentos técnicos para garantir a elaboração e atualização da documentação pedagógica. Tudo isso gerou transformações na pessoa que eu era. Sentia-me pouco preparada para responder ao volume de solicitações que eram feitas diariamente. Sentia que eram as relações interpessoais em todos os segmentos que se afirmavam como um tema de investigação e intervenção. 
Se por um lado iniciava minha jornada, trazendo expectativas para colaborar com a escola, por outro, sentia-me pequena face à complexidade dos problemas.

Percebia que desta complexidade erguia-se um sistema educacional falido. Seria possível acreditar que o Projeto Político Pedagógico da escola, daria conta de responder à fragilidade deste sistema educacional? Seríamos suficientemente corajosos para conviver com o crescimento do tráfico de drogas que assassinava jovens da comunidade?

Conheci na pele, o sentimento de orfandade que cerca o gestor da escola pública. A quem ele poderia recorrer? Afinal, seriam tantos os arrogantes interlocutores que the apontariam como o único culpado por todos os problemas a serem enfrentados. Mas esta lógica de caça aos culpados nunca me interessou. O que motivava minhas reflexões era a necessidade de apoio.

O que me mantinha nesta empreitada era o desejo da transformação. Ainda que fosse de uma pequena parte. Não poderia depender apenas das parcas (quando existiam) ações do sistema público para enfrentar as situações. Tinha que contar com o grande tigre que existia dentro de mim, com o qual também não sabia lidar muito bem. Ou seria o minotauro? Sabia que estava iniciando meu caminho na gestão. Havia muito que aprender. Contava com a colaboração dos mais experientes e com a minha intuição.

Portanto, estou longe de apontar os culpados pela falência da educação no sistema público. 0 que revelo é que em minha iniciação à coordenação pedagógica, vivenciei o sentimento de esvaziamento face às políticas públicas. Aquilo que Ferreira-Santos \& Almeida anunciam ao tratar das antropolíticas da educação:

A antropolítica é a área interdisciplinar, por excelência, que tematiza, para além do constructo abstrato do indivíduo, a relação da pessoa com o Outro no mundo concreto das mediações políticas e de poder, entre a subsistência material e o universo simbólico da cultura no mais banal e vivencial cotidiano, onde o algodão do imaginário é que serve de matéria prima para os fios míticos que constituem a trama social. (...)

A difícil fronteira na "res publica", dimensão das políticas públicas, é precisamente, a relação contrastiva com o Outro nas suas mais diferentes facetas: social, econômica, psíquica, intersubjetiva, política etc., mantendo em profundidade a invariabilidade de nossa estrutura como homo sapiens demens, a matizar, de maneira contraditória, os coloridos sociais das mais diversas conformações societárias. As meta-narrativas, como diria Lyotard, saturadas em suas utopias burocratizadas em programas, panfletos, jargões e modelos projetivos a se digladiarem pela conquista do poder, já exibiram à exaustão suas limitações no processo histórico, sobretudo, no ocidente. Como tentar compreender estas dimensões sem deslizar para as interpretações mais reducionistas? Sem degringolar para os economicismos, para os 
psicologismos, para os politicismos partidários, para os maniqueísmos simplistas que dividem o mundo entre dominantes e dominados, opressores e oprimidos, conservadores $e$ revolucionários, sem se darem conta da troca de cadeiras que efetuam, sem maiores escrúpulos, a partir das correlações de força e das estratégias de tomada de poder ${ }^{101}$ ?

\section{Então como continuar?}

Compreendi que era transgredindo o sentimento de impotência é que poderia me afirmar como organismo vivo, dentro de um sistema binário, que insistia em me identificar com o número de meu registro funcional e com o som da força de meu carimbo.

Infelizmente, é possível encontrarmos alguns colegas que foram seduzidos pela torpe ilusão do poder. A hierarquia separa, controla e entropiza.

Mas, para além da ilusão do poder e da ferida do sentimento de impotência, podemos ouvir a relva crescer, lá de onde brota a potência subterrânea. É nela que o corpo grita por seu espaço e as mãos exigem seu direito supremo de criação. Exigem dar forma, para então, formar-se.

Pois bem, estamos tratando de uma experimentação que tem como matéria prima a criação. Valorização e exercício do ser criativo que se revela no processo contínuo e inacabado de criar a si mesmo, nas suas criações. Isto é, dar forma a algo que ainda não existia no mundo e que, a partir da materialidade nas mãos sensíveis, Ihe dá existência. Portanto, lembrando Sirlene Giannotti, socorrendo-se da mestra Fayga Ostrower, se criar é dar forma, dar forma não seria formar-se? E esse processo criativo não finda num possível substantivo, mas se torna gerúndio ${ }^{102}$.

Sentindo a pulsão visceral é que se torna possível sobreviver à tecnoestrutura. Aquela que pretende tudo ver para controlar, amordaçar e engessar. Lugar no qual a criatividade é perseguida. O então, conhecido, discurso competente ${ }^{103}$.

Transgredir é buscar a potência subterrânea, o plasma existencial, a cultura instituinte. 0 magma da criação. Dar voz ao imaginário.

Deixar brotar as sementes, que as crianças, os jovens e os adultos trazem em germe, pois são pessoas potentes e criativas. Possuidoras de histórias e desejosas de alcançarem seus projetos. A escola sendo mera reprodutora dos programas, currículos e políticas públicas, perde seu espaço autoral, artesanal e visceral. Seus atores abatem-se. Tornam-se objetos. Alienam-se na

\footnotetext{
${ }^{101}$ Ferreira-Santos \& Almeida, 2011, p. 8-11

102 Ferreira-Santos \& Almeida, 2011, p.198

103 Chauí, 1984.
} 
jornada. Adoecem. Passam a projetar suas metas no consumismo. Então se consomem. Sucumbem ao poder do capital. E, disso, ninguém escapa.

Minha primeira experiência na coordenação pedagógica permitiu-me transitar entre os mundos da burocracia e do cotidiano. E pela incessante troca gerada entre eles fui interpretando os múltiplos papéis que a prática me exigia. Afetividade, corporeidade e sonho, mescladas de objetividade, racionalidade e controle.

Constatei, o que só anos mais tarde, reconheci nas palavras de Ferreira-Santos \& Almeida que:

Sem o exercício de nossos vínculos afetivos nas várias comunidades (de produção, de consumo, de convivência, de aprendizagens mestiças, educacionais etc.) e que pressupõe a base da construção constante, dinâmica, aberta, inacabada e complexa da pessoa, ficaremos ainda reféns das relações coisificadas, distantes, que convertem o Outro em objeto (de dominação, de exploração, de consumo, de desejo impulsivo, de prazer ilusório). Sem a vivência experimental da criação e seus processos simbólicos, poéticos, expressivos e estéticos nas mais variadas instâncias político-sociais e com as mais variadas linguagens artísticas, seja no âmbito das artes, da educação e da aula como obra de arte, dos processos de produção, nos embates ecológicos, permaneceremos reféns da reprodução acrítica das organizações, relações humanas e políticas, favorecendo o incremento dos tempos de barbárie, violência, degradação humana, miséria e solidão, resultantes do furor gestionário e do furor pedagógico ${ }^{104}$.

Lembro que numa de nossas vivências usei a música Perfeição tanto com os alunos, como com os professores. A partir dos sentimentos e pensamentos gerados por dela, poderiam representar as coisas que desejavam fazer a partir de uma nova primavera; e o que seria para cada um deles, a Perfeição.

\section{Perfeição \\ (Legião Urbana)}

Vamos celebrar a estupidez humana

A estupidez de todas as nações

O meu país e sua corja de assassinos

Covardes, estupradores e ladrões Vamos celebrar a estupidez do povo Nossa polícia e televisão Vamos celebrar nosso governo E nosso Estado, que não é nação Celebrar a juventude sem escola As crianças mortas Celebrar nossa desunião

\footnotetext{
104 2011, p. 11-2
} 
Vamos celebrar Eros e Thanatos

Persephone e Hades

Vamos celebrar nossa tristeza

Vamos celebrar nossa vaidade.

Vamos comemorar como idiotas

A cada fevereiro e feriado

Todos os mortos nas estradas

Os mortos por falta de hospitais

Vamos celebrar nossa justiça

A ganância e a difamação

Vamos celebrar os preconceitos

$O$ voto dos analfabetos

Comemorar a água podre

E todos os impostos

Queimadas, mentiras e sequestros

Nosso castelo de cartas marcadas

O trabalho escravo

Nosso pequeno universo

Toda hipocrisia e toda afetação

Todo roubo e toda a indiferença

Vamos celebrar epidemias:

É a festa da torcida campeã.

Vamos celebrar a fome

Não ter a quem ouvir

Não se ter a quem amar

Vamos alimentar o que é maldade

Vamos machucar um coração

Vamos celebrar nossa bandeira

Nosso passado de absurdos gloriosos

Tudo o que é gratuito e feio

Tudo que é normal

Vamos cantar juntos o Hino Nacional

(A lágrima é verdadeira)

Vamos celebrar nossa saudade

E comemorar a nossa solidão.

Vamos festejar a inveja

A intolerância e a incompreensão

Vamos celebrar a violência

E esquecer a nossa gente

Que trabalhou honestamente a vida inteira

E agora não tem mais direito a nada

Vamos celebrar a aberração

De toda a nossa falta de bom senso

Nosso descaso por educação

Vamos celebrar o horror

De tudo isso - com festa, velório e caixão

Está tudo morto e enterrado agora

Já que também podemos celebrar

A estupidez de quem cantou esta canção. 
Venha, meu coração está com pressa

Quando a esperança está dispersa

Só a verdade me liberta Chega de maldade e ilusão.

Venha, o amor tem sempre a porta aberta

E vem chegando a primavera -

Nosso futuro recomeça:

Venha, que o que vem é perfeição

Foi uma das experiências mais preservadas pela minha memória. Creio que ela já estava anunciando minha saída da escola, pois em função da complexa teia que caracteriza a estrutura de funcionamento da rede municipal, teria que me remover para outra escola, pois meu cargo era precário e dois outros coordenadores pedagógicos já tinham escolhido esta escola no período de remoção.

A minha primavera chegou ao ano seguinte. Na remoção consegui escolher uma escola de ensino fundamental, que atendia apenas ao Ciclo Inicial, turmas de primeira a quarta séries.

Apesar de ser, uma das escolas de "latinha", construídas na emergência, pela administração Maluf-Pitta, esta escola era muito bonita, organizada e acolhedora. Nela, permaneci por três anos.

Por ser uma escola que atendia apenas o ciclo I do Ensino Fundamental, sentia-me muito mais segura em coordenar, pois, tinha atuado neste nível efetivamente como professora.

Nesta experiência, participei de muitos cursos de especialização, promovidos pela Secretaria Municipal de Educação e pelo Instituto Qualidade em Educação, que tinham como foco atender aos educadores alfabetizadores. Tive a oportunidade de dividir a gestão com uma equipe mais experiente. A diretora era regida pelos ares de Atena. Persistente e guerreira para realizar as ações necessárias para tornar esta escola excelente. Acreditava na importância da formação. A escola contava com várias parcerias, o que me encantou como possibilidade de fortalecimento do projeto pedagógico.

Através de uma destas parcerias conseguimos produzir o jornal "Escola em Movimento". Foi uma oportunidade de dar função social às produções das crianças, professores, equipe de apoio e gestão. Nossas Mostras Culturais procuravam articular o trabalho da escola com as oficinas promovidas pela Associação Comunitária do bairro, (nas quais as crianças participavam de oficinas de capoeira, teatro, dança, jardinagem, culinária, basquete, voleibol e futebol no contra-turno da escola). Tínhamos parcerias com o Projeto Prove de Valorização do Educador 
(com outras EMEFs ${ }^{105}$ da região) e o mesmo instituto. A partir deles, pudemos contratar especialistas para auxiliarem na formação continuada dos grupos de estudo. Como coordenadora, ajudava a elaborar e organizar estes projetos e a colocá-los em prática. Foram três anos de grande intensidade. Lembro-me da grande participação da comunidade em todos os eventos promovidos: festas, reuniões, palestras, oficinas, cursos e atendimentos individualizados. A escola contava com uma ótima avaliação da comunidade. As crianças, em sua maioria, eram alfabetizadas dentro dos dois primeiros anos de escolaridade.

Também enfrentamos a resistência de alguns profissionais que não concordavam com o volume de ações da escola. Mas, pelo apoio do Conselho de Escola realizamos as propostas. Ainda que não tenhamos alcançado todos os objetivos, foram experiências que contribuíram para o desenvolvimento da escola como um todo.

No final de 2005, com a mudança da equipe técnica e a construção do novo prédio da escola, que a ampliaria de seis para dezesseis salas por turno, vivemos um processo de grande transformação. Passaríamos a atender também o Ciclo II do Ensino Fundamental. Internamente, vivi um luto, pois já tinha conhecido a realidade de falta de professores de determinadas áreas e o número enorme de aulas vagas. A estrutura de funcionamento do Ciclo I conseguia garantir o atendimento das crianças, contando inclusive, com o Projeto de Recuperação Paralela, no qual as crianças que tinham dificuldades de aprendizagem poderiam receber reforço.

Esta situação gerou grande insegurança. Tinha um sentimento de que este desafio era maior que minhas forças. Temia pela descontinuidade do projeto pedagógico, que até então estávamos realizando, e que embora tivesse suas fragilidades, dava identidade ao grupo. Era o projeto pedagógico e cada uma de nós que perdia suas referências.

Não houve nenhuma consulta à comunidade para saber de sua avaliação sobre o trabalho da escola. Fomos "comunicados" de todas as decisões que já tinham sido tomadas pela administração. A nova escola seria construída a dois quilômetros de distância, tendo um turno a menos de funcionamento. Passaria a atender de seis, dezesseis salas por turno, atendendo o Ciclo II, as turmas de quintas às sétimas séries.

Neste mesmo período, recebi o primeiro convite para trabalhar na Divisão de Orientação Técnico-Pedagógica da Coordenadoria de Educação de Campo Limpo.

Aceitei o convite, pois a diretora desta divisão DOT-P era uma pessoa por quem sempre tive confiança e admiração, e também, porque acreditei que o desafio poderia me trazer muita 
aprendizagem no trabalho de formação de educadores, especialmente, porque iria atuar na implementação do Programa Ler e Escrever - Prioridade na Escola Municipal. Tinha investido em frequentar cursos de formação para alfabetização e minha experiência na atuação com o Ciclo inicial do Ensino Fundamental poderia ser útil para o trabalho de formação.

Acima de tudo, esta nova experiência como formadora, poderia me ajudar a superar o luto de ver o Projeto Político Pedagógico da escola ser atropelado pelas decisões de cima para baixo, que não dialogaram e nem respeitaram a clientela.

Esta foi mais uma das aparições do vôo da Fênix. A morte de não ser mais coordenadora pedagógica, numa escola que amava, foi substituída pelo renascimento de uma nova oportunidade: ser formadora de educadores.

Temia a transformação, mas abri meus braços e o meu coração. Dediquei-me profundamente ao novo trabalho. Realizava formações com professores e gestores. Recebi todo o apoio da equipe de DOT-P durante esta empreitada entre os anos de 2006 até 2008.

Não havia uma identificação partidária, mas dividíamos crenças em relação à educação. Crença na possiblidade da formação continuada ser algo indispensável à valorização do educador. Sentíamos um sentimento de identidade muito agregador. Devíamos isso, provavelmente, não apenas aos nossos percursos individuais, mas no que nos tornávamos quando juntos. $E$ isto se devia ao encorajamento cotidiano e à confiança de nossa diretora. Nossa matriarca. Havia solidariedade, respeito e pertença. Isto nos ajudava, face às pressões das Políticas Públicas e da pressão em mostrar estatísticas. As rupturas sucessivas na gestão do sistema público, como de praxe, agravavam os problemas que são históricos na educação pública. Faltam-nos, não um plano decenal, mas um projeto de sociedade. Perdidos nas tramas do capital concebemos a possibilidade de compararmos o valor de uma vida a um dado per capita. Mas, afinal, qual o valor do ser humano? Do educador? Do educando?

Após trabalhar dois anos nesta divisão, decidi retornar para a coordenação pedagógica, especialmente, porque nesta ocasião, consegui indicar no concurso de remoção, uma escola de Educação Infantil. O outro motivo era a necessidade de investir em minha qualidade de vida e no meu casamento. O trabalho como formadora, por muitas vezes dilatava meu horário. Algumas vezes, precisando realizar formações no período noturno.

Creio que o motivo mais forte para retornar para a coordenação pedagógica, tenha sido o desejo de produzir uma prática mais autoral, com maior autonomia, sem tantas prescrições, dados os programas e a necessidade de transformarmos processos formativos em estatísticas. 
Esta pressão motivou-me a fazer mais um vôo. As questões que ressoavam em meu íntimo, em muito assemelhavam-se a estas:

A grande questão antropolítica é, neste caso, precisamente: o que é o ser humano? Numa perspectiva antropológica, onde se situa a pessoa? Como a realização do coletivo se dá na realização da própria pessoa e vice-versa? Como evitar que as estatísticas coisifiquem a questão humana? Como manter a tensão entre a perspectiva que privilegia a dimensão social de onde todas as relações emergem, sem perder de vista a dimensão vertical das pessoas em carne e osso, com sua dimensão existencial e trágica ${ }^{106}$ ?

Eis a nômade mais uma vez. Levei minhas bagagens pedagógicas para uma $\mathrm{EMEI}^{107}$ que funcionava dentro de um $\mathrm{CEU}^{108}$. Iniciava minha terceira experiência como coordenadora pedagógica, mas pela primeira vez, na Educação Infantil.

Era uma escola grande que funcionava em dois turnos, com doze salas em cada um. Tratava-se de uma gestão diferente de tudo o que conhecia, pois dentro do CEU, além da EMEI, funcionavam uma EMEF e um $\mathrm{CEI}^{109}$. O que solicitava um diálogo constante entre as três unidades articuladas à Gestão do CEU. Tanto no que se refere à organização dos tempos, quanto aos espaços, materiais e interações.

Desde o processo de organização escolar, no início do ano letivo, fiz uma leitura coletiva das avaliações dos professores sobre as necessidades da escola. Uma das prioridades apontadas era a reorganização dos espaços, observando a necessidade de se oferecer uma maior diversidade de experiências às crianças nas diferentes linguagens. Além disso, tornava-se necessário uma maior articulação entre a programação das rotinas da EMEl e as oficinas oferecidas pela Gestão do CEU.

Investi na reorganização dos espaços contando com o apoio dos professores e da direção. Nos horários de formação estudávamos bibliografias que nos aproximavam das concepções de Educação Infantil que compartilhávamos, e a partir dos estudos, passávamos às vivências de transformação dos espaços. Assim, reorganizamos a brinquedoteca, a sala de música e movimento e a sala de leitura contando com a parceria da Biblioteca do CEU.

\footnotetext{
${ }^{106}$ Ferreira-Santos \& Almeida, 2011, p.8

107 Escola Municipal de Educação Infantil.

${ }^{108}$ Centro Educacional Unificado.

${ }^{109}$ Centro de Educação Infantil.
} 
Outro foco de atuação era a discussão das rotinas a serem desenvolvidas em cada um dos espaços, ampliando as interações no refeitório, parque, pátio, sala de aula, piscina, teatro e oficinas. Organizava reuniões contando com a parceria de Postos de Saúde da região.

Foi uma árdua atuação. Participei das formações do Programa Rede em rede que em muito colaboraram para a minha atuação na gestão da Educação Infantil. Nessas formações, conheci as Orientações Curriculares e Expectativas de Aprendizagem para a Educação Infantil110. Também vivenciávamos o planejamento de atividades nas diferentes linguagens, o que ampliou meu repertório das práticas pedagógicas realizadas na Educação Infantil.

A reorganização dos espaços, associada aos estudos e às vivências ofereceram-me recursos para continuar pesquisando diferentes materiais e interações. Estava completamente envolvida com esta nova faixa etária, e ao estar mais próxima de crianças pequenas, fui me reconciliando com a minha infância. Por não ter vivenciado como criança uma escola de Educação Infantil, como adulta poderia recriá-la, um outro modo de dar forma, para formar-me.

Ver as crianças felizes correndo e brincando no parque, na brinquedoteca ou encantadas ouvindo histórias revelaram-me uma nova possibilidade na educação. Vê-las modelando, pintando, cantando, desenhando, jogando, crescendo... Eu crescia com elas.

Tal atitude - pois é disso que se trata, não se reduzindo a uma mera questão metodológica ou didática - funda-se numa imagem e concepção de ser humano (anthropos) que privilegia a construção cotidiana de nossa humanidade numa pessoa - na perspectiva da antropologia filosófica que a concebe como o campo de forças em tensão entre dois grandes vetores existenciais: de um lado, nossa subjetividade e seus desejos; de outro lado, a resistência do mundo concreto (Berdyaev, Mounier, Ricoeur, Durand, entre outros). A troca incessante entre esses dois vetores vai revelando o momento mítico de leitura em que se encontra a pessoa, diria Durand, no itinerário de formação, na jornada interpretativa: um percurso formativo de busca de sentido, busca de centramento e de plenitude existencial que se dá no processo de realização de si mesmo e que permite uma determinada leitura provisória do mundo. Por isso, um processo dinâmico, intenso e sempre inacabado. Ora, é precisamente essa pessoa que se encontra frente a nós numa situação educativa, com a sua capacidade própria e possível de ler o mundo naquele exato instante, exigindo de nós uma atitude ${ }^{111}$.

\footnotetext{
110 Orientações Curriculares: Expectativas de Aprendizagem e Orientações Didáticas para a Educação Infantil/ Secretaria Municipal de Educação - São Paulo: SME/ DOT, 2007

${ }^{111}$ Ferreira-Santos \& Almeida, 2011, 195-196
} 
As crianças experimentando novas possibilidades criavam com afetividade seus cenários e enredos, narrados com uma lógica poética própria, a de ser criança. Compartilhar com elas a experiência de criar ampliou minha compreensão sobre nossos percursos criativos.

Compreendemos na criação que a ulterior finalidade de nosso fazer seja poder ampliar em nós a experiência de vitalidade. Criar não representa um relaxamento ou esvaziamento pessoal, nem uma substituição imaginativa da realidade; criar representa uma intensificação do viver, um vivenciar-se no fazer; em vez de substituir a realidade é a realidade; é uma realidade que adquire dimensões novas pelo fato de nos articularmos, em nós e perante nós mesmos, em níveis de consciência mais elevados e mais complexos. Somos nós a realidade nova. Daí o sentimento de essencial e do necessário no criar, o sentimento de um crescimento interior em que nos ampliamos em nossa abertura para a vida ${ }^{112}$.

A Educação Infantil surgiu em meu percurso como um sopro de vida. Ainda que também tenha trazido o desafio de pesquisá-la. Em minha graduação na FEUSP tive aulas com a professora Marina Célia Morais Dias. Retomei algumas bibliografias por ela indicadas e fui buscando aprofundar meus conhecimentos sobre as bibliografias indicadas no site do professor Marcos Ferreira-Santos ${ }^{113}$, passei a pesquisar as contribuições do Lab_Arte/ FEUSP.

O brincar e as narrativas geradas em torno dele, ocupavam um grande espaço de nossas pautas de formação nos horários de estudo com as professoras. Percebi que observando e participando das brincadeiras junto com as crianças poderia aprofundar meu conhecimento sobre elas. Porém, a experiência mostrou que elas também passaram a me conhecer melhor. $E$ disso, surgiram vínculos. Deliciosos abraços. Insistentes:

- Dona Bete, vem ver o que fiz.

- Dona Bete, olha o que eu desenhei.

- Dona Bete, vem brincar com a gente.

- Conta mais outra história.

Finalmente, minha infância estava repleta de cores, risos e vozes. Realizei algumas vivências, com as professoras, pedindo para que escrevessem suas memórias da infância. As coisas de que mais gostavam. Seus brinquedos preferidos, seus livros e músicas.

É nesse momento que uma possível resposta nos adverte do óbvio ululante (saltitante aos nossos olhos): "Ora, pois: brincando!" O que é a brincadeira senão o ato recíproco de

\footnotetext{
112 Ostrower, 1996, p.28

113 Site: www.marculus.net
} 
imbricar dois ou mais seres na mesma situação existencial? E o que é esse imbricamento senão o jogo lúdico do reconhecimento sem outra finalidade senão a experimentação de si e do outro. Sim, a brincadeira é a situação básica de experimentação pelas crianças. E aqui o educador é também creança... criação contínua de si mesmo, desde que aberto às aprendizagens que, de repente, acontecem no jogo desinteressado da convivência. Haverá situação educativa mais profunda e mais significativa do que aprender-se e aprender o outro ensinando-se e sendo ensinado pela pessoa da criança ${ }^{114}$ ?

Reorganizei o espaço da sala dos professores para que garantíssemos um local de estudo, leituras e trocas. Isto trouxe um grande benefício para a continuidade das nossas reflexões, apesar da caótica rotina. Às vezes, dividíamos este espaço com as crianças que aguardavam suas famílias quando estavam adoentadas. Era ali também que a dimensão do cuidado foi revelando sua indissociabilidade com o educar.

Ao longo dos trabalhos, percebia que algumas professoras não legitimavam as ações do cuidar como necessárias ao educar. Também tive que pensar modos de sensibilizá-las para esta necessidade. Acompanhar uma criança em sua rotina no banheiro e no refeitório é algo tão importante quanto todas as outras rotinas. Esta é uma questão que toca a sensibilidade, algo que procurei dividir com as professoras no cotidiano, para conhecer suas práticas do lugar que ocupavam.

Era necessário fazer trocas de algumas crianças, auxiliá-las em sua higiene. Orientá-las na escovação. Organizá-las no refeitório, procurando humanizar estas ações as reconhecendo como pessoas, que ao serem cuidadas aprendiam a se cuidar e percebiam que eram importantes. Acredito que o fato, de contarmos com poucos funcionários para o acompanhamento das turmas, tenham também impulsionado minha atuação para participar destas rotinas quando necessário. Apesar, de agravar a descontinuidade dos processos, as ações de auxiliar a entrada e a saída dos grupos de crianças, os atendimentos à comunidade, o acompanhamento ao refeitório, banheiro e a realização de trocas, participaram do meu repertório, tanto quanto, os momentos nos quais planejava e participava das brincadeiras, das leituras, das rodas de conversa, das oficinas e dos ateliês.

Vivenciei uma relação de afeto, de respeito e de aprendizagem em cada uma das ações do cuidar. Reconhecer esta indissociabilidade passou a ser um dos temas de trabalho das formações em nossos horários de estudo.

\footnotetext{
${ }^{114}$ Ferreira-Santos \& Almeida, 2011, p.199-200.
} 
Tinha a sensação de ter encontrado meu lugar, o trabalho na Educação Infantil. Por mais desafiadoras que se mostrassem as situações, sentia-me com um perfil mais identificado a esta realidade, do que coordenando uma escola de ensino fundamental. O que ainda queria alcançar era poder realizar a gestão numa EMEI independente, isto é, que não estivesse vinculada à gestão de um CEU. Queria poder conhecer este trabalho da coordenação pedagógica numa unidade educacional convencional.

Em 2009, permaneci na Educação Infantil, porém numa EMEI que não se encontrava num CEU. Era uma escola que funcionava em três turnos, tendo seis salas em cada um deles. Localizava-se no Jardim Ângela, na zona Sul de São Paulo.

Tive a oportunidade de coordenar com muita afinidade com a direção. Tínhamos em comum o desejo de oportunizar a transformação. Investíamos na reorganização e criação de espaços para a oferta de diversidade para as crianças. Reorganizamos o acervo de livros para aproximar as crianças da leitura. "Brincar e Imaginar", este era o nome de nosso projeto de formação para os horários de estudo. Fui vivenciando a cultura da escola que contava com um corpo docente bem diverso. Algumas professoras estavam na escola, desde sua fundação, há quase vinte e cinco anos. Outras recém chegadas à escola e à Educação Infantil. Realizávamos o trabalho de tematização de práticas nas diferentes linguagens, mas tendo como foco, investigar o brincar que acontecia na escola. Nossa pergunta era: como poderíamos qualificar o brincar? Esta busca explicitava o reconhecimento da importância do brincar para o desenvolvimento das crianças.

Também organizamos o Projeto Horta contando com a participação das crianças, professoras, famílias e funcionários. Lembro que contávamos com uma agente de apoio, que era apaixonada pela terra, tinha trabalhado em sua infância na roça e era uma exímia cozinheira. Dado o processo de terceirização do trabalho de merenda, passou a trabalhar em outras funções de apoio na escola. Um dia, ela me procurou falando que gostaria de ajudar no que fosse necessário, para fazermos uma horta na escola. Fiquei muito empolgada com a ideia e a compartilhei com as professoras e com a direção.

Organizamos o projeto de plantio, trabalhando com as crianças suas etapas de realização. 0 preparo da terra, a escolha das sementes, o tempo de colheita, os cuidados necessários. Algumas crianças sugeriram que também fizéssemos o plantio de flores, pois assim a escola ficaria mais bonita.

A cultura do revolver a terra para plantar sementes é uma das metáforas mais adequadas ao tratarmos da Educação Infantil. Mas vivenciar o processo de cultivo de sementes e compartilhar o processo de geração da vida com as crianças, professoras, funcionários e famílias uma 
vivência inesquecível. As leituras de João e o Pé de Feijão, o brincar com o caldeirão da bruxa, o colher as cenouras, os tomates e alfaces. Ver um canteiro florido deu mais alegria a todos nós. Ficamos mais atentos aos processos de germinação.

A Festa Junina, também foi uma experiência inesquecível. Contou com a participação de todos, É certo que organizá-la foi um grande desafio. Mas aprendi muito com ele. Contava com o apoio da equipe. As crianças se divertiram muito na festa. Dançaram, brincaram, mostraram suas produções e seus familiares expressavam também estar felizes.

A mostra cultural deu visibilidade a cada um dos momentos de produção das crianças.

Participava das formações oferecidas pela Divisão de Orientação Técnico-Pedagógica (DOT-P). Além dos gestores (diretor e coordenador pedagógico), os professores também eram convidados a participar de formações externas de acordo com sua disponibilidade. Ao realizarem os trabalhos pessoais orientados pelos formadores dos cursos que frequentavam, as professoras compartilhavam suas práticas comigo.

Investimos em diferentes formas de registro das práticas (portifólios e diários de bordo), além dos cadernos de planejamento semanal que já realizavam.

Estava, finalmente, vendo a relva crescer. Talvez estivéssemos exercitando, aquilo que FerreiraSantos \& Almeida identificaram nas palavras de Cèlestin Freinet como um tatear experimental, descrito aqui, na metáfora navegante de Mondolfo ${ }^{115}$ :

O professor precisa compreender que não deve ser o rígido instrumento para a execução de um programa imposto pelo regulamento, senão o espírito vivo que anima a escola e que não considera os alunos como recipientes passivos onde se devem despejar as doses impostas pelo regulamento; precisa compreender que deve procurar nos alunos os colaboradores da sua própria obra, as energias frescas a serem postas em atividade. Os alunos sentem-se empurrados para o mestre pelos impulsos espontâneos das suas necessidades espirituais; é necessário que o mestre não transforme para si mesmo e para eles os programas em prisão, mas que vá livremente ao encontro das aspirações juvenis, que as anime dando-lhes orientação; o mestre deve ser o timoneiro de uma nave que não deve carregar mercadoria morta, mas apenas uma tripulação de marinheiros capazes de navegar ${ }^{116}$.

Estava navegando com o grupo num mar agitado e desconhecido. Estávamos experimentando possibilidades.

\footnotetext{
115 Mondolfo, 1967, p. 103-104

${ }^{116}$ Ferreira-Santos \& Almeida, 2011, p.28
} 
Neste ano, de tanta identificação profissional, começara a também navegar por mares desconhecidos na minha vida pessoal. O que antes, dava-me a sensação de porto seguro, transformou-se em areia movediça, anunciada pela crise de meu casamento. Passei por mudanças em minha vida pessoal que culminaram em meu divórcio. Foi um período que exigiu uma grande força interior para sobreviver à sensação de estar no centro do olho do furacão.

Como já descrevi, ao tratar da imagem do labirinto, como Ariadne, vivia um momento de redescoberta, indo do Hades do abandono ao novo vôo da Fênix. Mais um processo de morte, para um novo renascimento.

Com o divórcio, ressurgia a jornada da mulher arqueira que teria que buscar seu próprio pão e profundizar os alicerces de seu abrigo na força de seus próprios ombros. Teria que reconstruir as bases da minha subsistência. 


\section{A Sede do Corpo}

Estava entre lençóis

Sentia-me sonolenta

Mas bradava retumbante no silêncio

Um coração pulsante

Memórias, imagens, paixão

0 ressoar do eco do sonho

O sonho entre os mares e ondas

Ondas gigantes

Paredes transparentes, majestosas e reluzentes Anunciando e forjando o desconhecido porvir.

Mas agora imersa entre lençóis.

Delas ressurgi.

Gestada dos movimentos da maré da vida.

Da boca seca,

Dos olhos secos.

Dos braços e pernas doloridos

Dos joelhos e tornozelos enrijecidos

Rangiam e gritavam

Os tecidos, a pele, os nervos, os ossos e músculos.

Na solidão de um quarto de hospital

Vi refletidos no corpo os desejos, vontades e memórias da alma.

Meu corpo estava sedento

Desejava beber em novas fontes

Nas águas profundas

E delas evaporar

Em um novo estado

Gerado pelo encontro das águas frias e cristalinas e

De um corpo quente

Em chamas

Pulsante e desejante

Em seu interior

Queima um fogo sagrado

A partir deste encontro, a sede pode ser saciada

O poder da imagem em ação

A imagem forma o cenário

E o cenário a imagem

A mulher deitada entre lençóis

Passa a ouvir a relva crescer dentro de si.

Nova pele sendo gerada

Percebe suas células se renovando

O milagre da regeneração

Diante de si

O fogo restaurador traz das cinzas a fênix

É preciso morrer todos os dias

Para então renascer.

É preciso deixar a pele ressecada para trás

Reconstruir o reino devastado

Dele erigir um templo sagrado

Seria o grito do meu útero anunciando outras formas de gerar vida

De formar a si mesmo 
$\mathrm{Na}$ experiência de se reconhecer finito, mortal, frágil e solitário. Num quarto de hospital construímos novas formas de enxergar a vida.

Damos um sentido novo ao tempo e ao espaço.

Desejava me libertar dos medicamentos.

Medicamentos que pretendiam calar a dor.

Mas o coração sentia a necessidade de entender o que a voz da dor queria dizer Por que foi capaz de me paralisar no momento de maior intensidade do meu giro?

Por que foi capaz de parar o movimento frenético de meu corpo, meu fiel colaborador, motor do meu labor.

Meu fiel escudeiro,

Minha sagrada morada de minha alma inquieta A firme e generosa parafina que envolve e alimenta

a vibrante chama da vela da existência.

Dei-me conta

Quanto tempo ainda teria?

Quantas coisas já foram realizadas?

Quantas coisas ainda por realizar?

Quanto tempo ainda teria para além daquele vago instante?

O que poderia vir?

O que poderia ver?

O inaudito mistério erguia-se como paredões vigorosos de um mar profundo

Talvez a sombra do medo da morte

Que acompanha cada ser vivente

E junto da percepção deste medo a euforia de

Reconhecer-me viva...

Reconhecendo os limites de meu corpo, sentindo seus batimentos, controlando suas necessidades elementares.

Notei sua sede de atenção, de cuidado e de movimento.

Um corpo vivo está em pleno movimento ainda que esteja sobre uma cama de hospital.

Eis a imaginação...

A dança da vida enseja que o corpo e a alma permaneçam vibrando em cadências para além do sonho, na materialidade do existir.

À fome da alma sucedeu-se a sede do corpo recursiva e ciclicamente

Na rítmica incessante

Ambos amantes da pulsão que os anima

Ao se fundirem na expressão que nos faz

Viver cada instante

Como se fosse o último.

A concordância dos opostos, a reconciliação mística entre o corpo e a alma,

o pão e o vinho

O elo que laça a síntese em espiral

A coincidentia oppositorum

Retumbante no silêncio

Para além dos lençóis

Erguia-se das águas profundas

Perlaborando o magma

A senhora capaz de prover a sede ancestral

Poderosa fonte de vida.

Meu corpo dialogando com a minha alma

Talvez a metamorfose trazida

Pelas experiências vívidas e vividas

Estivessem transbordando as raízes da frondosa árvore para além do invólucro

A força da vida germinando a semente em crescimento permanente 
Fazendo florescer tudo o que dela se aproxima

Carece das forças da terra

Rompendo todas as formas transitórias que lhe serviram como sagrado vaso

Para então reenraizar-se à Terra Mãe

De onde nascemos e para onde retornamos maiores

Como estrelas ainda mais brilhantes

De uma constelação vibrante, reluzente e universal Imagens que pulsam

Em seus lampejos de lumina

Cada imagem conecta-se à constelação

Do Uno ao Todo

Ao vibrarem formam novas estrelas

Em cadeias infinitas

Pentágonos gerados entre o fluxo do encontro

Entre o feminino e o masculino

Estrelas pentagonais vibram em ressonâncias sonoras Mantras advindos da vibração entre o Todo e a Parte.

Instante de criação

Na profundidade do que somos

Na carne e no sopro

Ar em movimento

Eis o vento

E do reencontro dos quatro elementos

Na existência do que somos

Transmuta-se nossa quinta essência

Imaginação corporificada e sublimada

Na produção de nossas mãos

Da extensão gerada pelas falanges

A energia do movimento

Como chama reluzente

Transmuta a matéria e a própria essência

Tecendo, escrevendo, cozinhando,

Acariciando, esculpimos a nós mesmos

No corpo e na Alma

À fome da Alma e à sede do Corpo

Sucedem novas formas de criação

Delas nos alimentamos

Enquanto nos nutrem

Pela Poética...

Misterium Tremendus et Fascinans...

(ELISABETE MARTINS DA FONSECA) 


\section{A Sede do Corpo}

A poesia A Sede do Corpo foi escrita logo após minha internação em 2015. Neste período estava produzindo intensamente. Na escola, estava coordenando os projetos de Sessões Simultâneas de Músicas, Leituras e Brincadeiras, o projeto de plantio de sementes e mudas de flores e hortaliças - Semeando o Verde - e o projeto de empréstimo de livros. Ainda, havia investido em tornar os momentos de reuniões pedagógicas, momentos nos quais pudéssemos vivenciar experiências, podendo trazer para o plano das sensações corporais, algumas experiências compartilhadas: rodas de leitura, musicalização e movimento, confecção de brinquedos, planejamento compartilhado e antecipado das festas (festa junina, festa da semana da criança e do educador, festa de encerramento). Viabilização de espaços para a exposição das produções das crianças, tendo como eixo a confecção de um painel coletivo mensal no centro do pátio. Também liderei o processo de aplicação dos Indicadores de Qualidade para a Educação Infantil, no qual chamamos as famílias das crianças para participarem da avaliação da escola. Contamos com um número expressivo de participantes que contribuíram com sugestões para a melhoria da qualidade educacional nas diferentes dimensões avaliadas (planejamento e gestão educacional; multiplicidade de experiências e linguagens em contextos lúdicos para as infâncias; interações; promoção da saúde e bem estar: experiências de ser cuidado, cuidar de si, do outro e do mundo; ambientes educativos: espaços, tempos e materiais; formação e condições de trabalho dos educadores e das educadoras; rede de proteção sociocultural: unidade educacional, família/responsáveis, comunidade e cidade; relações étnico-raciais e de gênero; autoria, participação e escuta de bebês e crianças), o que sinalizou inúmeras demandas para o trabalho formativo, no sentido de qualificar o trabalho da escola.

Após a elaboração do plano de ações a partir desta avaliação, priorizamos investir, principalmente, nas dimensões que observam as relações étnico-raciais e de gênero e autoria, participação e escuta de bebês e crianças.

Considerando as contribuições das famílias, dos educadores em geral e das crianças, demos continuidade aos projetos já em andamento na escola, porém investindo com maior ênfase, no protagonismo das crianças, procurando atentar para as relações étnico-raciais e de gênero existentes em nosso cotidiano.

Dessa forma, estava em pleno processo de criação para o redimensionamento das ações formativas a serem desenvolvidas pelo trabalho pedagógico. Em cada dia da semana, procurava 
dedicar meu olhar para a abrangência das ações em andamento e sentia que estava faltando dias na semana para dar conta de todas as intenções desejadas. Mas fui abrindo caminho, identificando parcerias para a condução de cada um dos projetos. No encaminhamento das ações, foram surgindo educadoras madrinhas para cada um dos projetos, e assim, organizaram comigo comissões para acompanhar a realização dos trabalhos. Saíamos para comprar materiais para plantio e jardinagem. Investigávamos formas alternativas para a criação de um espaço para a realização deste projeto, já que a área externa da escola é pequena. Então, as professoras sugeriram que criássemos paredes vivas no pátio e nos muros, e também, aproveitássemos os pequenos espaços laterais do parque e da área de entrada, como canteiros. Além disso, estávamos reorganizando o espaço da brinquedoteca e da sala de leitura, substituindo o uso de pratos de plástico para o uso de pratos de vidro. Repensando as formas de organização das crianças para substituirmos o uso das filas separadas entre meninos e meninas. Repensando as formas de vivenciar o calendário de festas, para atender a diversidade cultural, procurando não reforçar uma única crença religiosa em detrimento das outras.

Todos estes temas trouxeram a necessidade do debate, de experimentações, que causaram a necessidade da criação de novas propostas, a partir de um processo contínuo de avaliação. Avaliação que promoveu a reflexão sobre os modos de ser da escola como um todo, e dessa forma, a observação mais atenta sobre as concepções que sustentam os nossos modos de agir. Nesse ponto, percebi que a complexidade trazida pelas resistências diárias - ao se debater estes temas, e as novas formas de experimentação de outros fazeres possíveis - evidenciava o quanto minha narrativa pessoal estava sendo construída na e pela intersecção de outras narrativas. Do mesmo modo que influenciava, também era influenciada pelo grupo. Também estava sendo provocada a rever meus modos de ser, pensar, sentir e agir como coordenadora pedagógica, e dessa forma, como pessoa, havendo assim, a necessidade da criação de um caminho dialógico para vivenciarmos nossas jornadas, como educadores, num tempo e espaço compartilhados.

Na urgência do desejo de querer realizar mudanças, percebi o quanto agia de maneira ansiosa, e algumas vezes, de um modo autoritário, querendo controlar todas as variáveis, como se isso fosse possível. Disso, muitas contradições puderam ser reconhecidas, pois no calor da rotina escolar passei a agir, algumas vezes, por impulso, de uma forma irrefletida ao propor a reflexão. Somente, durante o período de afastamento, durante a licença médica, é que consegui perceber o quanto agir de maneira impulsiva, estando sempre irritada e frustrada demonstrava que havia algo errado, que estava me afastando de quem era. Tinha algo muito intenso 
acontecendo comigo. Seria um estado de estresse profissional? Ou seria algo ainda mais profundo, acontecendo em minhas camadas mais subterrâneas. Seja o que fosse, admiti que não estava sob o meu controle. Ao menos, sob o meu controle estritamente racional.

A partir da reflexão gerada por Keleman, percebi que estava vivendo de uma maneira inautêntica com o meu modo se ser original, e assim, estava me agredindo, já que:

Quem você deve ser - isto é, quem lhe pedem que seja, de acordo com o seu papel em determinada sociedade - pode ser muito diferente de quem você nasceu para ser. Quem você se destina a ser foi determinado no momento da concepção pela maneira como o seu código corporal herdado organizou o seu tipo corporal constitucional. O processo somático tem muito a dizer sobre o modo como cada um experiencia seu senso de si e os mitos e histórias com os quais se identifica. ${ }^{117}$

Como coordenadora pedagógica, como gestora de um equipamento público, sou pressionada a fazer cumprir o que a legislação, a cultura instituída, assim me exige, ainda quando meu coração se revolta ao perceber as incoerências e o pouco investimento do poder público para a qualificação educacional. Em outras situações, este mesmo coração bate descompassado, quando percebe que não é possível realizar a atuação educacional, sem levar em conta o desejo do outro - seja este, um outro colega educador ou os educandos.

Cada pessoa tem seu ritmo, seu próprio modo de conceber o mundo e a si mesmo. E cada um de nós, não pode realizar nem mesmo a mudança de si, de um modo objetificante. Apenas vivendo como sujeitos da jornada é que podemos nos abrir para a escuta de nós mesmos e de nossos semelhantes, e assim, aprendermos a ser de outras formas, como seres integrais de corpo e alma.

Keleman ${ }^{118}$ afirma que a corporificação da sua própria forma determina a sua forma de estar vivo. Segundo ele, os ectomorfos ${ }^{119}$ vivem a partir da superfície de receptores sensoriais da pele e da rede amplificada de tecido nervoso central - a rede dos olhos, ouvidos, língua, nariz, articulações e vísceras. Os estímulos sensoriais formam uma pintura pontilhista, uma imagem

\footnotetext{
117 Keleman, 2001, p. 33

118 Idem, p. 34- 35

119 Keleman, ao longo de sua obra, faz referência a três possíveis tipos somáticos que, de maneira muito sintética aqui para fins didáticos, pode-se mencionar que: o ectomorfo tem tipo alongado, magro e esguio; o mesomorfo possui tipo médio com tronco pronunciado e membros mais proporcionais; o endomorfo possui tipo mais arredondado com ventre pronunciado em forma de pêra. Uma aproximação possível à arquetipologia durandiana com um ectomorfo dramático, um mesomorfo heroico e um endomorfo místico pode-se encontrar em Angelo, 2002. Cabe lembrar que não se trata de um determinismo fisiológico, pois é precisamente com o contato com o meio sócio-cultural que um tipo pode se sobrepor ao outro na mesma pessoa ao longo de seu processo formativo. Daí a necessidade do que Keleman denomina como prática de corparr.
} 
do self e do mundo. Um ectomomorfo tenta manter o contato sensorial sem ser avassalado pelo mundo externo. Busca aprofundar a corporificação, ligado, porém separado. O ectomorfo é o caubói solitário, o recluso incompreendido, o fazedor de imagens. Os mesomorfos geram excitação pela ação física - fazendo, performando, se autotestando. Eles extraem o seu poder dos músculos e do cérebro intermédio. Eles experienciam o seu "estar vivo" sendo fisicamente ativos. $\mathrm{O}$ endomorfo vive pelo seu apetite, para a sensualidade e para estar com pessoas. $\mathrm{O}$ endo tem um grande soma, um apetite que busca contato.

Admitindo a tese apresentada por Keleman, passei a refletir sobre o quanto me custava estar separada das pessoas enquanto atuava como gestora. De fato, passei a somatizar, o peso que estava carregando sobre os meus ombros, chegando a ter problemas em minha coluna cervical. Assim como, agindo de forma impulsiva, estava sofrendo ao afastar de uma agradável convivência, aqueles a quem enfrentava para realizar as ações necessárias à qualificação do trabalho pedagógico. Estava me sufocando, ao ponto de ter crises sucessivas de alergia e sinusite. Minhas vísceras estavam reivindicando mais espaço para seu ser original endomórfico, oxigenar a mulher que ama poesia, que ama estar com as pessoas, que tem um apetite pela busca do contato. Meu corpo estava evidenciando meu desejo de me fazer diferente, pela ilusão de que conseguimos transformar nosso mundo a ferro e fogo. Mas talvez, pudesse estar aberta ao meu próprio processo de transmutação, buscando trocar de pele, buscando o fogo das águas profundas. Mergulhando em mim mesma. Realizando a jornada, para um possível retorno. Buscava minha própria transformação.

Meu corpo estava refletindo este desejo de transformação. De reconciliação entre razão e emoção. De realização pessoal à profissional. De ouvir e de ser escutada em minhas ressonâncias míticas de onde extrairia a força motriz para continuar.

Meu corpo, meu templo sagrado, em seus renascimentos e pequenas mortes cotidianas me alertou para minha pouca vocação de catequizar os outros seguindo as cartilhas dos modismos político-pedagógicos. Ao adoecer, meu corpo potencializou a voz da minha alma, fazendo-me assumir que precisava prestar atenção em minhas dúvidas, sentimentos e desejos. Que precisava viver integralmente minha contradição humana. Integrar minha sombra, de não me reconhecer tão competente e durona, mas como pessoa que caminha ao lado de outras, tão humanas quanto eu. Deixar de seguir um padrão que não correspondia às minhas necessidades. Lembro aqui, que:

Esses padrões de corporificação são a história interior da nossa vida, a história do nosso self corporificado. Mas eles podem entrar em conflito com os padrões de uma sociedade que 
exige que sejamos aquilo de que ela necessita. Em nossa sociedade, por exemplo, você aprende a ser independente, racional, lógico, controlado. O poder deve ser encontrado, não da natureza, mas numa busca factual, objetiva e objetificante. Mas a função de buscar fatos afasta você da matriz emocional da sua vida. Distancia você da sua própria verdade subjetiva, que é irracional e racional ao mesmo tempo. ${ }^{120}$

Assim, a poesia "A Sede do Corpo" foi escrita, e nestes versos a seguir, destaco que:

Estava entre lençóis. Sentia-me sonolenta. Mas bradava retumbante no silêncio um coração pulsante. Memórias, imagens, paixão. O ressoar do eco do sonho. $O$ sonho entre os mares e ondas. Ondas gigantes. Paredes transparentes, majestosas e reluzentes anunciando e forjando o desconhecido porvir.

Mas agora imersa entre lençóis, delas ressurgi. Gestada dos movimentos da maré da vida. Da boca seca.

Dos olhos secos. Dos braços e pernas doloridos. Dos joelhos e tornozelos enrijecidos. Rangiam e gritavam. Os tecidos, a pele, os nervos, os ossos e músculos.

Na solidão de um quarto de hospital, vi refletidos no corpo os desejos, vontades e memórias da alma.

Meu corpo estava sedento. Desejava beber em novas fontes. Nas águas profundas e delas evaporar, em um novo estado. Gerado pelo encontro das águas frias e cristalinas e de um corpo quente, em chamas. Pulsante e desejante. Em seu interior queima um fogo sagrado. A partir deste encontro, a sede pode ser saciada.

Quando a escrevi, ainda não conhecia o que Keleman descreveu em sua tese e que a partir de minha identificação apresento a seguir:

Do grande coletivo somático, do código genético, surge a história da nossa identidade básica, da nossa predisposição para responder ao mundo de determinada maneira. 0 inconsciente somático, o reino do corpo desconhecido, da abundância generativa, é endomórfico. Dessa camada do nosso corpo nascem os mitos da criação, da Terra como Grande Mãe, até mesmo a teoria da evolução, da nossa vinda do oceano. Antes do surgimento dos poderosos caçadores mesomórficos, vivíamos cercados pela abundância da natureza. Estávamos empenhados na coleta de alimentos. A condição era de não-separação entre nós e o nosso ambiente. Uma imagem somática que reflete essa vida é a da Vênus de Olendorf: grandes quadris, grandes seios - os símbolos da fertilidade e da abundância da existência. Essa imagem é parte da nossa estrutura, parte do nosso inconsciente somático.

\footnotetext{
${ }^{120}$ Idem, p.35
} 
É o endomorfo em todos nós. Ela aparece em nossos sonhos, visões e relacionamentos amorosos. Todos nós crescemos no ventre da nossa mãe - o Jardim do Éden, uma parte da experiência inicial de cada um. O mito endomórfico está fundado em nossa primeira experiência corporal. ${ }^{121}$

Refletindo sobre a poesia e minha jornada, percebi o quanto em sua forma espiral, momentos voltam, imagens se repetem, mas nunca da mesma forma. Meus inícios em cada um de meus momentos de iniciação durante a jornada foram caracterizados pela fragilidade e temor. Pelo medo em não dar conta dos desafios que me eram colocados. Meus inícios durante a escolaridade, meu início como profissional, meu início acadêmico, meu início como esposa, todos eles são marcos referenciais de novas jornadas, que como tecelagem, ao passar do tempo, vão evidenciando suas formas ao serem religadas pela narrativa.

Não se trata de explicar seus mitos fundantes, mas de compreender a existência de uma provável matriz, que após buscar realimentar-se na placenta uterina, volta a seguir em sua caminhada, usando suas outras possibilidades de ser, para sobreviver face às novas necessidades da vida.

Assim a menina meiga e tagarela, um tanto medrosa, mas receptiva, foi aprendendo a ser outras meninas possíveis, aprendendo a se defender dos puxões de cabelo e piadinhas de coleguinhas não muito confiáveis. Foi vivenciando outros papéis, aprendendo outros ritmos como padrões para funcionar conforme a dança, que cada novo início exigia.

Lembrei-me dessas meninas que constituem a mulher que me tornei, durante minha internação. Percebi o quanto precisavam de uma pausa para tratarem de suas feridas durante o período que ajudaram a mulher a usar "o gládio" dentro e fora da escola. Nessas horas que a mulher age como leoa ou loba defendendo a si mesma e aos que estão confiados à sua proteção.

Reconheci minha dimensão selvagem ao exercer minha maternagem cuidando de minha família, de meus amigos e de meus colegas. Também ao cuidar de meus alunos adultos ou crianças.

Fui aprendendo que além de "empunhar o gládio", era tão ou mais importante, acolher no colo, proteger e também ensinar a voar. Tinha então que aproximar a figura da caçadora e da guerreira à grande mãe. E exercendo a maternagem cotidiana reconciliei a guerreira arqueira à mãe acolhedora.

${ }^{121}$ Idem, p. 35-36 
Descendo às águas profundas, pude com a prudente distância necessária, reconhecer os ecos do inconsciente corporificado, nas dores que foram sublimadas pelas palavras da narrativa ao reinventar-me conforme na poesia.

E do reencontro dos quatro elementos. Na existência do que somos. Transmuta-se nossa quinta essência. Imaginação corporificada e sublimada. Na produção de nossas mãos. Da extensão gerada pelas falanges. A energia do movimento como chama reluzente. Transmuta a matéria e a própria essência. Tecendo, escrevendo, cozinhando. Acariciando, esculpimos a nós mesmos. No corpo e na Alma. À fome da Alma e à sede do Corpo sucedem novas formas de criação. Delas nos alimentamos. Enquanto nos nutrem pela Poética... Misterium tremendus et fascinans...

São essas novas formas de criação que passaram a motivar minha regeneração. A imagem que reúne as águas profundas ao fogo sagrado da poesia foi expressa na figura da dançarina cigana. Sua saia vermelha com rendas enormes imitam as grandes ondas de um mar vermelho. A dança propõe um novo movimento a um corpo que se reconhece poético.

A dança é uma das formas mais antigas de comunicação criativa do homem. Ela tem uma peculiaridade que a diferencia de outras formas de expressão, que é o fato de ela existir sempre no presente. Ela é criada e recriada a cada instante. Durante sua execução, não há divisão entre o criador e a criação. Tudo se realiza dentro e através do dançarino. 0 instante poético da dança remete a uma vivência de eternidade. Essa dupla natureza da dança, que compreende a fugacidade do instante que passa e que também nos remete a uma dimensão atemporal, abre a possibilidade de contato com níveis mais profundos de vivência e visão criativa da existência. (...) O movimento está ligado à ideia de mudança, à noção do devir. (...) Laban pesquisou o movimento e a dança como fator de desenvolvimento humano, aliando aos aspectos físicos e fisiológicos, também o aspecto psíquico. A fonte da qual deve brotar a perfeição e o domínio do movimento é a compreensão da vida interior do homem, de onde se originam o movimento e a ação. (...) Assim como a água é um meio difundido para manter a vida, também o é o fluxo do movimento. O fluxo do movimento preenche todas as nossas funções e ações, permite-nos descarregar tensões internas prejudiciais e é um meio de comunicação entre as pessoas porque todas as nossas formas de expressão como a fala, a escrita e o corpo são conduzidas pelo fluxo do movimento. ${ }^{122}$

\footnotetext{
${ }^{122}$ Laban (1990) apud Almeida, 2009, p.15 e p. 50. Laban foi um dos primeiros frequentadores do Círculo de Eranos em Monte Veritá.
} 
Enquanto a imagem da dançarina cigana pulsar dentro de mim, estarei sempre ávida pelo movimento, isto é, estarei viva. É na ação da imagem que a imaginação sopra os ossos e devolve vida por onde passa, lembremos aqui do conto Carne de Língua.

Na dança quase flamenca que imaginei os movimentos eram circulares sendo gerados pela saia vermelha.

Eis a imaginação... A dança da vida enseja que o corpo e a alma permaneçam vibrando em cadências para além do sonho, na materialidade do existir. À fome da alma sucedeu-se a sede do corpo recursiva e ciclicamente. Na rítmica incessante ambos amantes da pulsão que os anima a se fundirem na expressão que nos faz viver cada instante como se fosse o último. A concordância dos opostos, a reconciliação mística entre o corpo e a alma, o pão e o vinho. O elo que laça a síntese em espiral: a coincidentia oppositorum.

Sempre gostei de dançar. Mesmo não tendo tanta habilidade toda vez que danço me sinto plena. Dançando reúno a umidade da transpiração corporal ao calor de seu movimento. Dança livre sem preocupação com resultados, mas prazerosa e brincante. Dança que em seu giro constrói ao meu redor um círculo acolhedor.

A concepção do movimento fluindo num espaço esférico envolve um princípio de conservação de energia. Essa noção energética é de vital importância para nossa proposta do movimento como fator de transformação e integração fisiopsiquica. No Oriente podemos observar essa noção no pensamento taoísta, especialmente nos exercícios propostos pelo tai chi chuan. No ocidente, essa concepção energética está ligada à Alquimia (...) Os alquimistas trabalhavam com a matéria e tentavam resgatar o espírito que eles julgavam ali aprisionado. No Ocidente eles acreditavam poder transformar os metais não nobres, como chumbo ou ferro, em ouro, através de várias operações alquímicas que iriam depurando a matéria bruta original até ela revelar sua essência, seu espírito: a Pedra Filosofal. No Oriente (China) a busca alquímica girava em torno de uma substância, um elixir, que garantiria a imortalidade. Aos poucos, alquimistas orientais e ocidentais foram se dando conta que ao trabalhar com a matéria o homem também retoma e aperfeiçoa a obra da natureza, ao mesmo tempo que trabalha para se fazer a si mesmo ${ }^{123}$.

\footnotetext{
${ }^{123}$ Almeida, 2009, p. 57-59
} 
Como num círculo recursivo, ciclicamente as imagens vão se sobrepondo dinamicamente: a lenda de Parsifal que buscava o Graal, um elixir de vida eterna capaz de trazer vida ao ser preenchido. A dança circular como caminho rumo à individuação.

(...) Jung, deu grande importância à alquimia, porque nela ele encontrou os fundamentos históricos da sua teoria dos arquétipos e do inconsciente coletivo e porque entendeu a transformação alquímica como um símbolo da transformação psicológica que ocorre no processo de individuação. (...) Ao considerar o processo de desenvolvimento e ampliação da consciência como um processo alquímico, Jung escapou do modelo biológico da psique e do referencial médico de patologia e cura, abrindo espaço para uma visão mais filosófica e criativa do ser humano, como um ser em busca de contínua transformação. ${ }^{124}$

Talvez assim possamos retomar a poesia "A Sede do Corpo" para lembrar de algumas perguntas que minha alma inquieta fazia.

Na experiência de se reconhecer finito, mortal, frágil e solitário. Num quarto de hospital construímos novas formas de enxergar a vida. Damos um sentido novo ao tempo e ao espaço. Desejava me libertar dos medicamentos. Medicamentos que pretendiam calar a dor. Mas o coração sentia a necessidade de entender o que a voz da dor queria dizer. Por que foi capaz de me paralisar no momento de maior intensidade do meu giro? Por que foi capaz de parar o movimento frenético de meu corpo, meu fiel colaborador, motor do meu labor, meu fiel escudeiro, minha sagrada morada de minha alma inquieta, a firme e generosa parafina que envolve e alimenta a vibrante chama da vela da existência? Afastando-me da frenética rotina é que tive a oportunidade de viver o que as imagens me diziam. Trilhando o caminho ao caminhar. Buscando compreender e não explicar. Percebi que a pausa fazia parte do movimento, semelhante ao ir e vir das marés.

A imaginação deve ser entendida aqui em seu sentido literal e clássico, ou seja, como verdadeira força de criar imagens, e não como fantasia. Ela constitui uma verdadeira função do pensamento ou do poder de representação, que não tece fantasias aleatórias, sem meta ou fundamento; assim, pois, não joga com os objetos, mas procura captar a realidade interior por meio de representações fiéis à natureza. Esta atividade é designada como sendo um "opus" (obra). ${ }^{125}$

\footnotetext{
${ }^{124}$ Idem, p.61-62

125 Jung (1994) apud Almeida, 2009, p. 65
} 
A narrativa autobiográfica permitiu que me reconciliasse com meu caminho, compreendendo que as coisas aconteceram do modo que deviam acontecer. O corpo adoeceu para que pudesse aceitar a necessidade de viver momentaneamente a latência de um casulo. Após o engolimento do casulo, a lagarta se transformaria numa borboleta. Na hora certa, renasceria. Mais que um processo de cura, a imaginação apontava para uma jornada em busca do Graal: a própria individuação. As imagens iam forjando a obra. O opus do ser.

Lidar com imagens (...) é, portanto, um equivalente de cultivo da alma. (...) Imaginar significa libertar os eventos de sua compreensão literal para uma apreciação mítica. ${ }^{126}$

Imagens que pulsam em seus lampejos de lumina. Cada imagem conecta-se à constelação. Do Uno ao Todo. Ao vibrarem formam novas estrelas. Em cadeias infinitas. Pentágonos gerados entre o fluxo do encontro entre o feminino e o masculino. Estrelas pentagonais vibram em ressonâncias sonoras. Mantras advindos da vibração entre o Todo e a Parte. Instante de criação. Na profundidade do que somos.

E por essas imagens, outros instantes são lembrados na construção da narrativa. Com Ariadne, busco o seu fio, andando pelo labirinto, encontrando o que tratarei no próximo capítulo como lumina profundis, o que me ajudaria a compreender o lado selvagem da mulher loba, da cigana que dança e se move com seu corpo reconciliada com a sombra - o minotauro, parte de si. Instinto e razão a caminho de seu empoderamento.

O fogo restaurador traz das cinzas a fênix. É preciso morrer todos os dias para então renascer. É preciso deixar a pele ressecada para trás. Reconstruir o reino devastado. Dele erigir um templo sagrado.

Procuramos mostrar, com efeito, que o fogo é, dentre os fatores de imagens, o mais dialetizado. Só ele é sujeito e objeto. Quando se vai ao fundo de um animismo, encontra-se sempre um calorismo. O que reconheço de vivo, é o que reconheço como quente. O calor é a prova por excelência da riqueza e da permanência substanciais, por si só oferece um sentido imediato à intensidade vital, à intensidade de ser. ${ }^{127}$

Estamos a caminho das águas reluzentes do fogo: lumina profundis.

\footnotetext{
${ }^{126}$ Hillman (1992) apud Almeida, 2009, p.67

${ }^{127}$ Bachelard, 1994, p.162
} 


\section{O Vôo da Borboleta}

\section{Ariadne, Ártemis e o encontro de Lumina profundis}

"Talvez fosse apenas falta de vida: estava vivendo menos do que podia e imaginava que sua sede pedisse inundações.

Talvez apenas alguns goles..."

(Clarice Lispector- Perto do Coração Selvagem)

Ariadne é uma das Grandes Mães, a Grande Deusa de Creta. Como tal, chama-se "a poderosa", "a senhora do labirinto", "a intocável". Perguntar quem é Ariadne, a fim de seguir o fio do começo ao fim, leva-nos ao centro de um labirinto, onde encontramos a própria Ariadne. No princípio existe Ariadne, uma Deusa completa em si mesma, andrógina e autoperpetuadora, criando com base em seu próprio ser, sem necessidade de outrem. Essa Ariadne é substituída por outra que se relaciona com o masculino como algo externo a si mesma, embora seja uma criação dela e inteiramente à sua disposição. Nessa fase, representa-se Ariadne acompanhada de uma figura masculina submissa, o macho que surge da morte, que é filho e amante e, finalmente, vítima. É claro então, à medida que prosseguimos nessa história, que Ariadne era de início a figura importante, e Dioniso o "outro" necessário. Por começar como um Deus que morre e ressurge, Dioniso é ainda, mesmo no período clássico, o Deus que aparece e desaparece. Até no Olimpo, Dioniso ajuda a recordar-nos do tempo em que os Deuses eram filhos e depois amantes, em seguida morriam e reapareciam como filhos renascidos, tornando-se amantes mais uma vez para de novo morrerem, e assim sucessivamente.

A ligação particular de Ariadne com a morte está naturalmente representada de forma preeminente pelo labirinto, do qual a maioria jamais retorna, mas de onde alguns voltam transformados. Em Argos, como convém a uma Deusa da morte, seu túmulo serve de altar. O que mais intriga porém é que Ariadne sofre a morte de vários modos. Entre essas histórias de morte, conta-se aquela, já mencionada, em que ela é morta por Ártemis. Outra fala que ela simplesmente morre de tristeza, e uma terceira nos diz que ela se suicida, enforcando-se numa árvore, desesperada com a partida de Teseu.

Mais interessante de todas é a tradição segundo a qual Ariadne morre justamente antes de dar à luz. Dizem alguns que Teseu deixou a Ariadne à revelia, aos cuidados de parteiras de Náxos (ou Dia, outra ilha frequentemente mencionada nas tradições de Ariadne) por ter 
chegado a hora dela. Conta-se que Ártemis matou-a com a criança ainda no ventre, o que lembra as mortes de Côronis e Sêmele. Mas, enquanto Asclépio e Dioniso são salvos a tempo do ventre de suas mães que morrem, Ariadne entra no reino da morte com a criança não nascida ainda em seu interior e então - prossegue a história- dá à luz. Este é o único relato na mitologia grega de um nascimento no mundo dos mortos, indício de que se tem aqui algo de fascinante e de profundo ${ }^{128}$.

Na transição entre os anos de 2009 e 2010, enquanto reorganizava questões práticas da minha vida, desde os aspectos emocionais, jurídicos e materiais, recebi um novo convite, de uma velha e querida amiga matriarca, que certamente, sabendo dos problemas que estava enfrentando, mais uma vez me estendeu a mão. Tratava-se de voltar ao trabalho como formadora no DOT-P, desta vez, para trabalhar auxiliando nos cursos da Educação Infantil e também para atuar como professora no curso de Pedagogia numa universidade em Santo Amaro. Sendo coordenadora deste curso, relatou a confiança que tinha no meu trabalho e no quanto seria positivo, atuar no magistério superior, tanto em termos financeiros quanto para minha auto-realização.

De fato, já havia sido convidada a voltar para o DOT-P, no início de 2009, pela formadora que atuava diretamente, nas formações do Programa Rede em rede. Mas, o que me encorajou a aceitar o duplo convite foi o conjunto de mudanças na minha vida. Voltaria a atuar como formadora num tema que me trazia encantamento: a Educação Infantil. Estaria num grupo pelo qual nutria pertencimento. Além disso, pela primeira vez, após o mestrado, teria a oportunidade de trabalhar no ensino superior. Poderia reorganizar minha situação financeira, após os percalços de uma separação; mas acima de tudo, estava sendo acolhida, como na metáfora, Ariadne foi socorrida pelas parteiras em Náxos, minhas parceiras de DOT-P, fraternalmente, colaboravam para que não me sentisse sozinha, numa ilha. Também contribuíam numa tecelagem silenciosa, para meu fortalecimento, para que num futuro próximo pudesse dar à luz. Estava renascendo mais uma vez, buscando minha selvagem força interior.

Em 2010, iniciei na docência na graduação do curso de Pedagogia, na modalidade presencial e também no ensino à distância.

\footnotetext{
${ }^{128}$ Downing, 1992, p. $170-1$
} 
Pensei em alguns momentos, que não fosse conseguir conciliar a carga horária. Além disso, cheguei a lecionar sete disciplinas no meu primeiro ano atuando no ensino superior, que exigiam muito preparo, estudo e dedicação.

Mas, face ao desafio e o apoio recebido, curiosamente, percebi que só podia contar com a força do meu interior. Com o sentimento do sagrado que me animava e que acreditava em meu próprio potencial. Não podia desistir. Nem do trabalho, nem da vida e nem de mim.

Não seria justo desapontar tanta confiança. Não seria justo abandonar-me. Teria que chegar ao ponto mais central do labirinto para me reconciliar com Lumina profundis ${ }^{129}$. E o trabalho exaustivo foi um dos meios. Produzindo incessantemente, na minha dupla atuação, fui desafiada a aprender coisas novas, a interagir com pessoas diferentes e a fazer o que antes nunca tinha experimentado. A respeito de Lumina profundis no Crepúsculo Selvagem das Origens orienta-nos Ferreira-Santos:

Este ser selvagem nos parece ser, propriamente, aquele que mobiliza e é mobilizado em sua metáfora por excelência: a Arte. Parece ser aquele que silencia e fala; que deixa aparecer e desaparece; que fugaz, repousa na origem de tudo. Merleau-Ponty nos diria, nesse sentido, que: "a comunicação de uma cultura constituída com outra se faz por meio da região selvagem onde todas nasceram." (...) Uma iluminação dessa região selvagem originária pressupõe clarear o caminho somente o suficiente, somente como o olhar (/umina, em latim) que avança cotejando as penumbras e luscos-fuscos da peregrinação na profundidade dos significados. Não se trata da enciclopedista ilustração (Aufklärung) que cega de tanta luz, de tanta fé na razão, na ciência e na república. Ao contrário, é aquele olhar de soslaio de que trata nossa escritora mestra, Clarice Lispector. Vislumbre que impregna, emprenha, engravida, fecunda... Aqui são divagações que tateiam o sensível, a compreensão e o jardim epicurista (képos) dos amigos na interrogação cotidiana dos sentidos da existência, na ajuda mútua comunal das pessoas em pequenos feitos. Nem se trata mais da salvação do mundo por bandeiras tremulantes de qualquer que seja o credo (marxista, neoliberal ou fundamentalista), sempre prestes a eliminar o mundo no desejo mesmo de salvá-lo. Mas, lumina profundis, olha o mundo desde o subterrâneo num conhecimento crepuscular (Durand, 1995, p.83; Ferreira-Santos, 1998, p. 147). Silenciar ante os trovões. Caminhar lento na tempestade ${ }^{130}$.

\footnotetext{
${ }^{129}$ Durand, 1995, p.83; Ferreira-Santos, 1998, p. 147

130 Ferreira-Santos, 2005, p.111-112.
} 
Na primavera de 2010, quando completava trinta e seis anos, ganhei um presente maravilhoso de minha parceira de Educação Infantil, o livro: "Mulheres que Correm com os Lobos: Mitos e Histórias do Arquétipo da Mulher Selvagem", de Clarissa Pinkola Estès ${ }^{131}$. Na época, estávamos desenvolvendo o "Projeto Entorno: Em busca de Novos Leitores" - em parceria com a Fundação Victor Civita - e trocávamos livros como presentes. E ela não poderia ter escolhido outro melhor. Como minha grande amiga, iniciou-me aos caminhos que também já trilhava, a reconciliação com o nosso lobo interior, nossa força selvagem. Talvez, o minotauro? A respeito deste trabalho Estés afirma:

As histórias são bálsamos medicinais. Achei as histórias interessantes desde que ouvi a minha primeira. Elas têm uma força! Não exigem que faça nada, que se aja de nenhum modo - basta que prestemos atenção. A cura para qualquer dano ou para resgatar algum impulso psíquico perdido está nas histórias. Elas suscitam interesse, tristeza, perguntas, anseios e compreensões que fazem aflorar o arquétipo, nesse caso o da Mulher Selvagem. (...) Este é um livro de histórias de mulheres, apresentadas como marcos ao longo do caminho. Elas são para você ler, refletir e prosseguir na direção da sua própria liberdade natural e conquistada, do seu carinho para consigo mesma, para com os animais, a terra, as crianças, as irmãs, os amantes e os homens. Já vou the avisar: as portas para o mundo da Mulher Selvagem são poucas, porém valiosas. Se você tem uma cicatriz profunda, ela é uma porta; se você tem uma história muito antiga, ela é uma porta. Se você gosta do céu e da água tanto que mal consegue aguentar, isso é uma porta. Se você anseia por uma vida mais profunda, mais plena, por uma vida sã, isso é uma porta ${ }^{132}$.

Lembro estar me recuperando de uma paralisia facial que tive no final de outubro de 2010 , e então iniciar a leitura deste livro, que muito ia se assemelhando a busca da cura de uma alma ferida e com toda a sede de meu corpo. Precisava entrar em contato com a minha ferida e uivar a minha dor, para então correr ao encontro da Lua.

Meu corpo dava sinais de que tinha que viver um luto. De que tinha que olhar para meus limites. Viver intensamente.

Logo após a cura da paralisia facial iniciei meu processo de celebração do corpo. Saía para dançar algumas vezes, gostava da brisa da noite e da sensação de liberdade que o vento trazia ao bater no meu cabelo, quando dirigia sozinha, em meus momentos de descanso. Uma força

\footnotetext{
131 Estès, 1994.

132 1994, p.30 e 37
} 
selvagem estava me transformando. Não pretendo nomeá-la: se era minotauro, instinto, animus, lobo ou lumina profundis. Mas percebi sua intensidade. Jamais seria a mesma.

Era a partir dela que queria explorar novas experiências, romper fronteiras, sem me apegar a nada em particular, mas viver a intensidade do todo. Cuidar para que a caça saciasse um desejo que vorava minha alma.

Lembro aqui Bolen:

Ártemis, conhecida pelos romanos como Diana, era a deusa da caça e da lua. A alta e adorável filha de Zeus e Leto percorria a região da floresta, da montanha, da campina e da clareira com seu bando de ninfas e cães de caça. Vestida com uma túnica curta, equipada com arco de prata e aljava de setas ao ombro, era arqueira de infalível pontaria. Como deusa da lua ela também é apresentada como portadora de luz, levando tochas nas mãos, ou com a lua e as estrelas ao redor de sua cabeça ${ }^{133}$.

A busca da independência, da brisa noturna, das viagens para a praia, da contemplação das grandes ondas do mar e dos instintos. Esta foi uma fase importante no meu processo de renascimento. Descobrir um caminho de reconciliação entre razão e instinto. Ler muitas histórias também foi uma forma de ouvir minhas vozes interiores.

Estés ao tratar do resgate da intuição como iniciação afirma:

O antigo conto russo de Vasalisa é a história praticamente intacta da iniciação de uma mulher. Ele trata da percepção de que a maioria das coisas não é o que parece. Como mulheres recorremos à nossa intuição e aos nossos instintos para farejar tudo. Usamos nossos sentidos para espremer a verdade das coisas, para extrair o alimento das ideias, para ver o que há para ser visto, para conhecer o que há para ser conhecido, para ser as guardiãs do fogo criativo e para ter uma compreensão íntima dos ciclos de vida-morte-vida de toda a natureza - assim é uma mulher iniciada. Eis as etapas de iniciação, a partir do rito da velha deusa selvagem, Baba Yaga: permitir a morte da mãe-boa-demais; denunciar a natureza sombria; navegar nas trevas; servir o não-racional; separar isso daquilo (aprender mais sobre a vida e a morte); perguntar sobre os mistérios (saber demais pode envelhecer a pessoa antes do tempo); se colocar de pé nas quatro patas (seguir adiante na vida, com os pés firmes, um atrás do outro, como uma mulher); reformular a sombra (cuidar da nossa arte e reatar nossos vínculos com os instintos selvagens) ${ }^{134}$.

\footnotetext{
133 Bolen, 1990, p. 78 e 82.

134 Estès, 1994, p.99.
} 
Minha atuação lendo histórias, acompanhando as formações que vivenciavam a música, o movimento, os jogos teatrais, a apropriação do conhecimento matemático, do desenho, da natureza e da sociedade, desenvolvendo oficinas no curso de Pedagogia, mostrava a importância do afrontamento da presença da pessoa em seu processo de formação pela experiência. Indicava a importância da arte para a formação do educador, naquilo que possa desenvolver uma educação de sensibilidade:

Trata-se de uma modalidade possível de se compreender e agir no âmbito dos processos educativos, sejam eles em termos de autoformação, os itinerários de formação, seja no modelo escolar, a partir de uma razão sensível, do exercício da imaginação, da experimentação poética e valorização do imaginário para lidar com a alteridade sem mecanismos etnocêntricos. Aqui se privilegia o refinamento da sensibilidade através de todos os sentidos (visão, audição, paladar, tato, olfato, intuição, cinestesia), com a preocupação de inter-relacionar ética e estética num contexto dialógico em que mestre e aprendiz troquem, incessantemente, de lugar, atualizando o arquétipo do mestre-aprendiz. Nesta concepção se compreende a educação como o processo pelo qual se constrói, pela própria pessoa, sua humanidade. Partilhamos uma concepção de educação, ampla e antiga, que remonta à própria etimologia do termo em sua raiz latina: ex ducere - o que significa dizer que algo é conduzido para fora, conduzido para o exterior; ajuda-se a parir... destino parideiro (maiêutico) do velho mestre Sócrates. Dar vazão à potência que se inscreve na corporeidade das pessoas. A educação de sensibilidade considera a educação como um fim em si mesma e não como meio para se atingir finalidades instrumentais. Não se trata, portanto, de uma educação para o trabalho, educação para a cidadania, educação para a inclusão etc. Ela própria é a finalidade última de suas práticas: trazer para fora a humanidade potencial que há nas pessoas (humanitas). ${ }^{135}$

Minha experiência atuando na escola e na universidade indicava que uma educação de sensibilidade tornava-se necessária na formação de pedagogos. Para além de cursos instrumentais apressados pela lógica do capital, percebia que era importante investir profundamente na formação do educador. Buscar uma formação integral atenta à arte, à corporeidade e à criação. Precisamos vivenciar a sensibilidade em suas múltiplas linguagens, aproximando-nos da vitalidade da criança em sua imaginação brincante.

Segundo Larrosa Bondía:

\footnotetext{
${ }^{135}$ Ferreira-Santos \& Almeida, 2012, p.69
} 
“Vamos agora ao que nos ensina a própria palavra experiência. A palavra experiência vem do latim experiri, provar (experimentar). A experiência é em primeiro lugar um encontro ou uma relação com algo que se experimenta, que se prova. O radical é periri, que se encontra também em periculum, perigo. A raiz indo-européia é per, com a qual se relaciona antes de tudo a idéia de travessia, e secundariamente a idéia de prova. Em grego há numerosos derivados dessa raiz que marcam a travessia, perainô, ir até o fim; peras, limite. E o percorrido, a passagem: peirô, atravessar: pera, mais além; peraô, passar através. Em nossas línguas há uma bela palavra que tem esse per grego de travessia: a palavra peiratês, pirata. O sujeito da experiência tem algo desse ser fascinante que se expõe atravessando um espaço indeterminado e perigoso, pondo-se nele à prova e buscando nele a sua oportunidade, sua ocasião. A palavra experiência tem o ex de exterior, de estrangeiro, de exílio, de estranho e também do ex de existência. A experiência é passagem da existência, a passagem de um ser que não tem essência ou razão ou fundamento, mas que simplesmente "ex-iste" de uma forma sempre singular, finita, imanente, contingente. Em alemão, experiência é Erfahrung, que contém o fahren de viajar. E do antigo alto-alemão fara também deriva Gefahr, perigo, e gefährden, pôr em perigo. Tanto nas línguas germânicas como nas latinas, a palavra experiência contém inseparavelmente a dimensão de travessia e perigo. ${ }^{136}$

Minha atuação como professora no ensino à distância possibilitou-me muitas aprendizagens, principalmente ao dar aulas ao vivo, via satélite, atingindo um público de mais de mil alunos simultaneamente. As ferramentas dos ambientes virtuais, também permitiam a interação com os alunos. Mas, o meu trabalho no ensino presencial é que me nutria, pela troca dos olhares; pela transpiração e entrega do trabalho realizado junto aos alunos, observando as mudanças oportunizadas pelo curso, a partir de suas atitudes e das suas produções.

Em 2011, estava realizando a organização de um seminário para apresentar as práticas pedagógicas de Educação Infantil da região de Campo Limpo. Como uma das modalidades apresentadas, realizamos o registro do Livro da Vida, junto aos gestores que atuavam na Educação Infantil. Em todo o processo de organização, compartilhar os registros das histórias de vida dos gestores foi uma experiência de identificação importante para a constituição e fortalecimento deste grupo.

\footnotetext{
${ }^{136}$ Jorge Larrosa Bondía da Universidade de Barcelona, Espanha no artigo "Notas sobre a Experiência e o Saber de Experiência" publicado na Revista Brasileira de Educação Jan/Fev/Mar/Abr de 2002 a partir da Conferência proferida no I Seminário Internacional de Educação de Campinas, traduzida e publicada, em julho de 2001, por Leituras SME; Textos-subsídios ao trabalho pedagógico das unidades da Rede Municipal de Educação de Campinas. Atualizado no livro publicado recentemente de Larrosa, 2015.
} 
Os grupos de formação dos gestores permitiam um espaço para que pudessem trocar suas experiências, articular as visões da direção e da coordenação pedagógica, ao mesmo tempo em que construíam estratégias de gestão. Mediar esses processos, usando a literatura, a música, a modelagem, a brincadeira, os jogos e o movimento, permitia-nos dar forma à nossa própria formação.

Essas trocas entre os gestores despertaram-me para a riqueza destes encontros, levando-me a busca do Doutorado. Queria investigar a gestão na Educação Infantil a partir da memória e dos processos formativos. Uma das questões iniciais era a de investigar como os gestores enfrentavam os desafios trazidos pela educação em tempo integral.

Foi então que decidi retornar à FEUSP. Voltar às raízes. Beber na fonte para nutrir o sonho. Unir as pontas desencapadas do novelo que juntas poderiam me devolver o fio.

Estés ao tratar do canto profundo flamenco, el canto hondo, no processo de iniciação da mulher afirma que:

Agir como sombra significa ter um toque tão suave, um passo tão leve, que torne possível uma movimentação livre pela floresta, observando sem ser observada. A loba segue como sombra qualquer um ou qualquer coisa que passe pelo seu território. É sua maneira de colher informações. É o equivalente de manifestar-se, transformar-se em algo como fumaça para voltar a se manifestar. (...) A grande força selvagem das nossas próprias psiques quer pôr sua pata na nossa sombra, afirmando dessa forma, que the pertencemos. Assim que a Mulher Selvagem prender nossa sombra, voltamos a nos pertencer, sentimo-nos no nosso ambiente e na nossa terra natal de direito. (...) Começamos nossa procura do selvagem, quer ainda meninas, quer já adultas, porque no meio de alguma empreitada selvática sentimos a proximidade de uma presença selvagem a nos dar apoio. Talvez tenhamos visto seu rastro atravessando a neve solta num sonho. Ou, em termos psíquicos, percebemos um galhinho quebrado aqui e ali, seixos virados de modo que seu lado úmido estivesse voltado para cima... e soubemos que algo de abençoado havia cruzado nosso caminho. Dentro da nossa psique, pressentimos ao longe o som de uma respiração conhecida, sentimos tremores no chão e soubemos no nosso íntimo que algo de poderoso, alguém importante, alguma liberdade selvagem dentro de nós estava se movimentando ${ }^{137}$.

Seguindo pelos processos iniciáticos do labirinto, passei a reconhecer a necessidade de olharmos para a formação do educador que atinja mais que discursos a sua prática efetiva. Valorizar o saber-fazer deste educador que compartilha com os aprendizes o próprio percurso

\footnotetext{
137 1994, p. 561-2
} 
da vida. E, sobretudo, desta educadora que além de tudo trilha também o caminho de constituir-se como mulher nos campos áridos da educação.

Na relação entre as pesquisas do imaginário e a educação, desenha-se uma pedagogia do imaginário que, no dizer de Sanchez Teixeira, não é um conjunto de técnicas ou estratégias de ensino e muito menos uma disciplina cujo conteúdo trate do imaginário ou da criatividade. (...) Uma pedagogia do imaginário, como metáfora, seria a porta-voz dos deuses que renascem. Ela é a metáfora do processo pelo qual o imaginário conduz a nossa vida, atribuindo-lhe sentido. E, nesse sentido, ela é sim uma educação fática, uma educação da alma, uma educação da sensibilidade.

Portanto, essa educação de sensibilidade reafirma a constatação de que um processo educativo autêntico não pode prescindir do diálogo, da paixão e da liberdade, isto é, da autonomia da pessoa em realizar-se. A capacidade de decidir algo, de se posicionar no mundo e afrontá-lo somente se aprende em situações de decisão, de afrontamento, de tomada de consciência, no exercício de uma pedagogia da escolha. ${ }^{138}$

Acredito que na diversidade dos papéis nos quais atuei, sempre refleti sobre em que medida é possível reconhecer uma educação de sensibilidade na formação do pedagogo e da pedagoga, e especialmente, no cotidiano escolar. Trata-se de se pensar e sentir sobre uma formação na qual a arte, a corporeidade, a poesia e a liberdade estejam presentes, humanizando a condição de se perceber como educador, tornando-nos pessoas.

\footnotetext{
${ }^{138}$ Ferreira-Santos \& Almeida, 2012, p.69-71
} 


\title{
Prósopon: Em Busca da Experiência Numinosa do Ser
}

\author{
Bola de Meia, Bola de Gude \\ (Milton Nascimento e Fernando Brant)
}

Há um menino, há um moleque, morando sempre no meu coração

Toda vez que o adulto balança ele vem pra me dar a mão

Há um passado no meu presente, o sol bem quente lá no meu quintal

Toda vez que a bruxa me assombra o menino me dá a mão

Me fala de coisas bonitas que eu acredito que não deixarão de existir

Amizade, palavra, respeito, caráter, bondade, alegria e amor

Pois não posso, não devo, não quero viver como toda essa gente insiste em viver

E não posso aceitar sossegado qualquer sacanagem ser coisa normal

Bola de meia, bola de gude, o solidário não quer solidão

Toda vez que a tristeza me alcança o menino me dá a mão

Há um menino, há um moleque morando sempre no meu coração

toda vez que o adulto balança ele vem pra me dar a mão

Há um menino, há um moleque morando sempre no meu coração

Toda vez que o adulto balança ele vem pra me dar a mão

Há um passado, no meu presente, um Sol bem quente lá no meu quintal

Toda vez que a bruxa me assusta o menino me dá a mão

Ele fala de coisas bonitas que eu acredito que não deixarão de existir

Amizade, palavra, respeito, caráter, bondade, alegria e amor Pois não posso, não devo, não quero viver como toda essa gente insiste em viver

E não posso aceitar sossegado qualquer sacanagem ser coisa normal

Bola de Meia, Bola de gude, o solidário não quer solidão Toda vez que a tristeza me alcança o menino me dá a mão Há um menino, há um moleque morando sempre no meu coração toda vez que o adulto fraqueja ele vem pra me dar a mão

Iniciei a jornada do Doutorado em 2012. Ano no qual cursei a maior parte das disciplinas. Cada uma delas contribuiu ao seu modo para redimensionar as bases do projeto de investigação: a autobiografia como caminho hermenêutico.

Ao cursar a disciplina "As Narrativas da Tradição Oral e a Formação de Educadores Artistas" a partir das contribuições e das indicações bibliográficas da professora Regina Machado tive a oportunidade de "acordar" para outras formas de construir o conhecimento, a partir da arte de contar histórias. 
Desde nossa primeira aula, vivenciamos situações de encontro em contato com a arte da narração, nas quais as histórias que foram contadas pela professora Regina Machado entraram em interação com nossas leituras, em ressonância com as nossas histórias pessoais.

Em nossas aulas a partir dos contos estabelecíamos uma troca entre o que a história trazia para nós e o que nós trazíamos de nós para ela.

Machado afirma:

As grandes questões da pós-modernidade extrapolam as discussões de físicos e filósofos, chegando até nós, pessoas comuns, de uma forma simples e contundente: não apenas não sabemos o nosso lugar no mundo, como temos medo de quase tudo, de sair pela rua de noite e de dia, de olhar para nós mesmos e não encontrar ninguém. Fico pensando em alguém que resolve dedicar algumas horas de sua vida lendo histórias para uma criança desconhecida, deitada numa cama de hospital. Não é o medo que une essas duas pessoas nesse instante. Ambas transitam, cada uma pela sua própria história, dentro do conto. Não se trata de negar ou fugir da dura realidade, do medo ou da impotência. Experimentam a si mesmas em outras possibilidades de existir além do medo. É nesse caos de começo de milênio que a imaginação criadora pode operar como possibilidade humana de conceber o desenho de um mundo melhor. Por isso, talvez a arte de contar histórias esteja renascendo por toda parte. Os contos milenares são guardiães de uma sabedoria intocada, que atravessa gerações e culturas; partindo de uma questão, necessidade, conflito ou busca, desenrolam trajetos de personagens exemplares, ultrapassando obstáculos e provas, enfrentando o medo, o risco, o fracasso, encontrando o amor, o humor, a morte, para se transformarem ao final da história em seres outros, diferentes e melhores do que no início do conto. O que faz com que nós, narradores, leitores e ouvintes, nos vejamos com outros olhos. Somos nós os protagonistas, é a nossa própria história que nós contamos enquanto vivemos, é um relato exemplar. Enquanto estamos dentro do conto, experimentamos a certeza de que valores humanos fundamentais como a dignidade, a beleza, o amor e a possibilidade simbólica de nos tornarmos reis permanecem vivos em algum lugar dentro de nós ${ }^{139}$.

É, precisamente, nesse ponto que situo a importância de retomarmos os nossos percursos formativos como narrativas de si. De perguntar quais são as nossas histórias preferidas? Se costumamos contá-las para as crianças? De que forma o fazemos?

\footnotetext{
${ }^{139}$ Machado, 2004, p.15
} 
Os contos que nos foram contados desde nossa infância constituem nossos cenários imaginários, e mais que isso, constituem nossas histórias. E até que ponto se pode recuperá-los em nossas memórias?

Ao relatar como foi a experiência de ouvir um determinado conto, cada pessoa mostra que ouviu um conto, o seu. Algumas coisas chamaram sua atenção, outras não. Às vezes ela é o personagem e vive com ele suas aventuras. Outra pessoa observa o cenário como alguém que vê de fora o desenrolar da trama, outra pessoa se emociona e uma outra ainda, se pergunta sobre a adequação de tal ou qual episódio e assim por diante. O que importa é que o conto estabelece uma conversa entre sua forma objetiva - a narrativa - e as ressonâncias subjetivas que desencadeia, produzindo um determinado efeito particular sobre cada ouvinte. As imagens do conto, acordam, revelam, alimentam e instigam o universo de imagens internas que, ao longo de sua história, dão forma e sentido às experiências de uma pessoa no mundo. Este lugar para onde a pessoa se transporta é o lugar da imaginação enquanto possibilidade criadora e integrativa do homem. Quando experimento estar dentro da história, experimento a integridade individual de alguém que não está nem no passado, nem no futuro, mas no instante do agora onde encontro em mim não o que fui ou o que serei, mas a minha inteireza no lugar onde a norma e a regra enquanto coerção da exterioridade do mundo não chegam. Onde eu sou rei ou rainha do reino virtual das possibilidades, o reino da imaginação criadora. Nesse lugar encontro não o que devo, mas o que posso, portanto, entro em contato com a possibilidade de afirmação do poder criador humano, configurado em constelações de imagens ${ }^{140}$.

Como cada um de nós reconta? Que recursos nossa memória utiliza para manter fidedignamente ao conto? Como compartilhamos nossas memórias?

Ecléa Bosi destaca que:

O trabalho com a memória não nos aprisiona no passado, mas nos conduz ao enfrentamento dos problemas presentes. $O$ ato de relembrar conjuntamente, isto é, o ato de compartilhar a memória, é um trabalho que constrói sólidas pontes de relacionamento entre os indivíduos. A memória uma vez sendo subjetiva e social, reflete suas representações culturais. É coletiva e também singular. Quem narra a memória o faz de forma autoral ${ }^{141}$.

A memória de cada sujeito recupera a história de um período, de um grupo, de uma cultura.

\footnotetext{
140 Machado, 2004, p. 24

${ }^{141}$ Bosi, 1994, p.407
} 
É preciso perceber a realidade do conto, do mundo encantado do "pode ser" para se compreender o efeito que as histórias milenares produzem até hoje no ser humano que somos. Longe de ser ilusão, o maravilhoso nos fala de valores humanos fundamentais que se atualizam e ganham significado para cada momento da história das sociedades humanas, no instante que o conto é relatado. Assim como, o mito, a lenda e a saga, o conto maravilhoso não é só um relato circunscrito a um determinado tempo histórico, mas traz na sua própria natureza a possibilidade atemporal de falar da experiência humana como uma aventura que todos os seres humanos compartilham, vivida em cada circunstância histórica de acordo com as características específicas de cada lugar e de cada povo para transcender ao tempo e à morte ${ }^{142}$.

A mitologia se ancora no corpo, um produto da imaginação do soma (energia corporal). O que os nossos corpos dizem? E o que eles estão nos contando? A imaginação humana está enraizada nas energias do corpo. E os órgãos do corpo são os determinantes dessas energias e dos conflitos entre os sistemas de impulso dos órgãos e a harmonização desses conflitos. Esses são os assuntos de que tratam os mitos. Um mito expressa uma visão do mundo social e pessoal, representa uma cosmologia. A fonte do mito e do conhecimento corporal está em nós mesmos. Ela é intensificada pelas interações e diálogos somáticos.

O mito trata da jornada do corpo, recriando a si mesmo continuamente, de um modo particular, para formar uma estrutura pessoal individual chamada self $f^{143}$.

Podemos pensar em nós mesmos como um processo vivo, continuamente organizando e corporificando tudo aquilo que encontramos.

É por esse motivo que as jornadas e os caminhos são tão importantes no mito. A história do outro, do herói, do personagem que contamos a nós mesmos é, na verdade, a história do nosso próprio processo. E como usamos a nós mesmos para encenar as imagens míticas conhecidas ou desconhecidas que são parte da nossa vida? Como vivemos a nossa vida? ${ }^{144}$

Desta forma, procurar as brechas para uma educação de sensibilidade na formação do educador e da educadora e no cotidiano escolar, não apenas permitiria o reconhecimento dos códigos expressos pela formalidade instituída, mas por meio dela, também se reconheceria o imaginário - o conteúdo profundo ancorado no universo da vida do grupo, a sua dimensão

\footnotetext{
${ }^{142}$ Machado, 2004, p.24

${ }^{143}$ Keleman, 2001, p.25

${ }^{144}$ Keleman, 2001, p.91
} 
arquetípica-biológica-cultural expressa nos gestos, nos ritos e na própria corporeidade dos sujeitos desse grupo.

Lembremos que para Gilbert Durand o imaginário se produz e é produzido no trajeto antropológico, entendido como a incessante troca que existe entre as pulsões subjetivas e assimiladoras e as intimações objetivas do meio cósmico e social.

Nesta incessante troca entre as pulsões subjetivas e o meio cósmico social, estabelece-se uma articulação entre a Natureza/Bios, as invariâncias universais do comportamento humano e a Cultura/Logos, as variações e modulações do comportamento inserido em contextos culturais específicos e unidades grupais. Articulação manifesta através das práticas simbólicas inseridas em nosso cotidiano.

Durand ${ }^{145}$, admitindo as convergências da reflexologia, da tecnologia e da sociologia, admite três gestualidades primordiais comuns à humanidade - postural, digestiva e sexual - as "dominantes reflexas" das quais decorrem três estruturas básicas: a heróica, a mística e a sintética, que se organizam em dois regimes de imagens: o Regime Diurno e o Regime Noturno. Estas estruturas do imaginário, segundo Durand, são a manifestação de uma fantástica transcendental, que assegura uma função de eufemização inerente ao fenômeno humano, a partir da análise, num nível teórico, das imagens provenientes de diversas culturas, expressas nas narrações míticas, na literatura e nas diversas formas de expressão artística. Assim o imaginário de cada pessoa enraíza-se em sua bio-história e no seu contexto-social, numa relação dialógica, num trajeto antropológico, no qual o imaginário é a própria experiência de vida.

A autobiografia revelando suas emoções e suas sínteses na captação dos sentidos ofereceu-me elementos para a continuidade desta investigação.

Ecléa Bosi ao tratar da memória e socialização afirma:

A criança recebe do passado não só os dados da história escrita; mergulha suas raízes na história vivida, ou melhor, sobrevivida, das pessoas de idade que tomaram parte na sua socialização. Sem estas haveria apenas uma competência abstrata para lidar com os dados do passado, mas não a memória' ${ }^{146}$.

Como educadores, somos frutos do nosso tempo e inspiradores de novas gerações.

\footnotetext{
145 Durand, 1997.

146 Bosi, 1994, p.197
} 
Todos nós representamos um personagem social e um personagem pessoal e nós os representamos no palco das nossas interações sociais. Descobrir como invocamos as nossas diferentes formas emocionais nos ajuda a descobrir as histórias que vivemos. Quando prestamos atenção às nossas histórias, aprendemos alguma coisa a respeito de como corporificamos a nossa vida. Essa é uma das funções da mitologia.

Contar uma história funciona como um organizador que ajuda a corporificar a sua experiência. Não somente o ajuda a organizar o sentido, mas também faz o significado nascer de dentro, mesmo, do seu self corporal. $\mathrm{O}$ ato de contar histórias organiza as suas respostas numa forma narrativa que você pode usar para dar sentido e direção à sua experiência ${ }^{147}$.

Durante o curso "As Narrativas da Tradição Oral e a Formação de Educadores Artistas" ouvimos, lemos e vivenciamos um conto muito especial, entre todos os que tivemos contato durante as aulas, chamado: Um Sonho.

Nesse conto, como protagonista, havia um jovem que sonhava ser escriba do rei. Imaginação e realidade em sintonia a partir do estudo criador do conto, realizado pela mediação da professora Regina Machado. Em cada encontro, nós nos envolvíamos com o estudo do conto ao mesmo tempo em que íamos nos aprofundando em nosso próprio processo iniciático, como "pesquisadores escribas" buscando escrever nossas perguntas, teorias e poesias...

A partir do estudo da sequência narrativa, perguntávamo-nos sobre a ideia nuclear do conto, daquilo que ele nos trazia como motor: perguntando-nos o que o conto tem para mim? 0 que tenho para o conto?

Vivenciamos a experiência dos climas do conto, sentindo seu ritmo e pulsação. Estudamos seus personagens até nos aproximarmos de suas qualidades. Fomos em cada aula percebendo, concebendo e materializando novas formas de recontá-lo.

Analogamente, fomos vivenciando outras formas de aproximação com o conhecimento, pelas sistematizações dos saberes construídos, a partir da experiência de ouvir e contar histórias. Num outro conto, um camponês conheceu através da visita à casa de seu primo numa outra cidade o que era ter água encanada. Ficou tão empolgado com a imagem da água saindo pela torneira que nem perguntou ao primo como havia chegado àquela maravilha.

\footnotetext{
${ }^{147}$ Keleman, 2001, p. 31
} 
Queria reproduzir o milagre da água o mais rapidamente possível. Chegando a sua cidade, comprou uma torneira e a fixou na parede. Ansioso, antes mesmo de testar sua obra, chamou a todos para apresentá-la.

Este conto possibilitou nossa reflexão acerca da construção do conhecimento. E, particularmente, de nosso processo de criação. Afinal, qual o grau de aprofundamento temos a respeito de nossas pesquisas? Quais são nossas motivações?

A torneira tão frágil e rapidamente fixada do conto foi exposta ao olhar dos outros, sem mesmo saber quais os recursos que seriam necessários para a sua realização.

Perguntar, investigar, experimentar, submeter-se ao erro, buscar a fonte apropriada e os caminhos/meios para trazê-la até nós, torna-se o trabalho árduo do pesquisador...

Um pesquisador que pode buscar na fonte da tradição oral, os contos e os saberes gerados pela experiência milenar transmitida de geração para geração. A busca dos recursos oferecidos pela cultura ancestral, como fonte de conhecimento, ao ser canalizada por cada um de nós é recriada por novas conexões, pelas apropriações que fazemos, em função de nossas oportunidades e diferentes visões de mundo. O conhecimento que finalmente é apresentado (pela abertura das torneiras de nossas dissertações e teses) revela nossas percepções, concepções e concretizações relacionadas a como nos conectamos com esta fonte.

Que final daríamos para esta história? Como trazer água potável, fresca e caudalosa por encanamentos tão diversos? Como seria a apresentação de nossa torneira?

A escuta e a leitura de contos tradicionais podem nutrir, despertar, valorizar e exercitar o contato com as imagens internas, abrindo as possibilidades para que as questões das crianças estejam enraizadas no sentido de perguntar. Sua experiência pessoal de valores humanos fundamentais pode ser exercitada no contato com os contos tradicionais. Neles, cada narrativa expressa um caminho, um percurso de desenvolvimento, envolvendo necessidades, questões e conquistas: os desafios, provas e obstáculos permeiam a ações de heróis e heroínas que enfrentam situações em que valores humanos como coragem, liberdade, beleza, determinação e justiça subjugam o medo, a inveja, a covardia e a traição. ${ }^{148}$

o "esquema da torneira" - ou o processo de construção do conhecimento - é uma oportunidade de estarmos abertos ao novo, ao misterioso, ao que nos parece curioso, numa

\footnotetext{
148 Machado, 2004, p.34
} 
alusão ao processo de "aprender a aprender" descrito por Dewey a respeito da construção do conhecimento pela criança.

É como se tivéssemos dentro de nós uma floresta cheia de árvores enfileiradas. No dia a dia, nós utilizamos apenas as árvores da frente para cumprirmos nossas tarefas sociais. (...) Mas existem muitas outras árvores que o condicionamento não atinge, cada vez mais para dentro da floresta, que são as imagens significativas por meio das quais guardamos o que é realmente importante para nós, ao longo de nossa vida. É para essas árvores que os contos tradicionais se dirigem quando entramos em contato com eles. Fazem acordar as árvores mais significativas da floresta ${ }^{149}$.

A natureza fundamental da narração viva de contos é justamente essa qualidade especial de encontro entre pessoas. Quando a experiência com a ancestralidade é acessada produz-se uma nova qualidade humana, na qual podemos ouvir nossa voz interior (recursos internos, a parte de nós que sabe intuitivamente) a partir da escuta de um conto.

A tradição oral é o repositório da ancestralidade humana. Toca a melodia que está dentro de nós, pela escuta do que vem de fora. A troca gerada pela narração de um conto se dá no instante em que tempo, lugar e pessoas interagem em ressonância.

A qualidade da narração está ligada a cada um desses elementos. Um contador de histórias precisa estar atento a eles.

O Contador de Histórias poderia dizer: - História, para você eu tenho a minha presença. A presença é feita de intenção, ritmo e técnica. Um bom contador de histórias, guiado pela ação interligada desses três fatores, exercita habilidades pessoais - recursos internos -, combinadas com amplo repertório de informações disponíveis - recursos externos - , enquanto vai polindo e conquistando, ao longo da vida, a qualidade da presença. (...) A intenção, o ritmo e a técnica constroem passo a passo a possibilidade da presença, a capacidade de responder criadoramente a tudo que ocorre no instante da narração, com vivacidade e confiança. Confiança na potencialidade de seus recursos externos e internos, confiança na história como um presente que ele oferece a si mesmo e à sua audiência. Estar presente é poder presentear ${ }^{150}$.

Participar do curso "As Narrativas da Tradição Oral e a Formação de Educadores Artistas" foi uma oportunidade preciosa de reconduzir meu olhar sobre o tema de minha pesquisa.

\footnotetext{
149 Machado, 2004, p. 27

150 Machado, 2004, p. 81
} 
Recorro à metáfora do pirata que atravessa o mar das palavras para tratar desta experiência de ressignificar a própria história. Pirata que se aventura no imaginário na esperança de criar novas formas da gestão pedagógica.

Aventura investigativa que pretende priorizar a infância como campo privilegiado para a criação. Possibilitando ao educador que procura ressignificar seus percursos e à criança ali protagonizada, brincando, a reinvenção de uma escola mais poética.

Ao brincar podemos criar poeticamente, imaginamos e ressignificamos esteticamente o real. Ao brincar reconciliamo-nos com o homo ludens, criamos "um parênteses no tempo e no espaço", emergindo como possibilidade simbólica, ao se distinguir da vida comum tanto pelo lugar quanto pela duração que ocupa. Tem suas regras próprias, definindo sua ordem, ritmo e harmonia.

Nesse sentido, a qualidade lúdica pode ser própria das ações mais elevadas. O jogo aproxima-se da esfera do sagrado em sua dimensão de recolhimento do sujeito em um tempo e espaço próprios. Nos ritos sagrados o homem celebra. As consagrações, os sacrifícios, as danças e competições sagradas, as representações, os mistérios, tudo isso vai constituir uma dimensão de alegria, festa, libertação da condição do "real". Existem entre a festa e o jogo, naturalmente, as mais estreitas relações. Ambos implicam uma eliminação da vida cotidiana, mantendo sua seriedade, naquilo que permitem à condição humana: a de imaginar.

Pelo jogo somos levados para um lugar e um tempo diferentes "da claridade do dia". Dimensão na qual nos assemelhamos à criança, ao poeta, ao homem primitivo e ao selvagem que nos habita. O divertimento do jogo aproxima-nos de nossa essência imaginativa. O jogo possui uma realidade autônoma, não material.

Assim, se verificarmos que o jogo se baseia na manipulação de certas imagens, numa certa imaginação da realidade (ou seja, a transformação desta em imagens), nossa preocupação fundamental será, então, captar o valor e o significado dessas imagens e dessa imaginação. Observaremos a ação destas no próprio jogo, procurando assim compreendê-lo como fator cultural da vida.

Jogando vivemos, assim negamos a morte. Existimos em nossa essência que é a própria do jogo. É nesse sentido que o brincar em sua dimensão cultural revela-se como uma necessidade humana desde a infância.

A partir da linguagem criamos, reinventamos o mundo e a nós mesmos pelas palavras, pelas metáforas, pela imaginação. A linguagem como produção cultural inicia o sujeito humano em um modo de ser, pensar, sentir, expressar, imaginar e realizar. 
Em meu itinerário de formação desde a infância, reconheço a importância do brincar, desde a imaginação de cenários, personagens, figurinos, vocabulários, sentimentos, pensamentos, acolhimento e desafio. Talvez, por isso, tenha chegado à Educação Infantil.

Nem sempre foi possível reconhecer educadores que brincavam com as crianças. Que se divertiam com elas. Que apresentavam em sua corporeidade um bem-estar em seu fazer.

Mas foi a partir das contribuições das disciplinas e da orientação do professor Marcos FerreiraSantos que cheguei à experiência do brincar em sua profundidade a partir da vivência de assistirmos ao documentário: Sementes do Nosso Quintal. Numa vivência em uma de suas aulas, na disciplina Mitohermenêuticas da Arte: Ancestralidade e Criação, eu tive contato com o documentário e com a reaproximação ao referencial teórico que sempre esteve presente em minha formação inicial.

Estas vivências oportunizadas pela disciplina inspiraram duas ações que realizei ao atuar como formadora. Nesse processo de reinventar a formação de educadores na Educação Infantil, vivi dois grandes momentos de síntese e autorealização.

Ao organizarmos o Seminário de Educação Infantil pude contar com a presença de Marcos Ferreira-Santos e Therezita Pagani que apresentaram o documentário "Sementes do Nosso Quintal" aos gestores de Educação Infantil da Diretoria Regional de Educação de Campo Limpo.

Foi uma experiência transgressora das Políticas Públicas. O documentário trouxe estranhamento para alguns gestores que julgaram as práticas da Te-Arte muito diferentes e algumas vezes arriscadas para as crianças que colocavam literalmente, suas mãos na massa, ao brincarem e se apropriarem do espaço do "quintal mágico".

Para outros, o documentário trouxe uma forma autêntica de se relacionar com a infância, ao acreditar na potência da criança sem subestimá-la, trazendo uma poética, uma possibilidade de recriação dos saberes e fazeres na educação infantil.

Assistir o documentário oportunizou o reencontro com a sábia simplicidade de uma educação de sensibilidade, atualizada em sua ancestralidade. Durante o seminário perguntava-me sobre o lugar que desejava ocupar. Cada vez mais me identificava com os questionamentos que relativizavam a qualidade das práticas prescritivas, sinalizando suas limitações. Cada vez mais desejava reinventar minha atuação, humanizar meu fazer pelo imaginário, vivenciando uma educação infantil viva, autêntica e aberta para a experimentação.

Um outro momento marcante, foi trazer a ceramista Sirlene Giannotti para vivenciarmos um ateliê com argila junto com os gestores. Nessa vivência de extrema sensibilidade a mestra das 
mãos recorreu a várias imagens, num diálogo que atingia a memória e a infância dos participantes.

Nessa produção das mãos animada pela alma, recorro às palavras Bachelard, citado na dissertação de mestrado de Sirlene Giannotti:

Dar forma é formar-se. Eis então, em sua mais estreita conexão, o cogito amassador: há uma maneira de apertar o punho para que a nossa própria carne se revele como essa massa primordial, essa massa perfeita que resiste e cede ao mesmo tempo (...) Assim, sei lá que massa primordial em minhas mãos vazias, todo o meu sonho manual, murmuro: tudo me é massa, eu sou massa de mim mesmo, meu devir é minha própria matéria, minha própria matéria é ação e paixão, sou verdadeiramente uma massa primordial ${ }^{151}$.

Enquanto amassávamos a argila entrávamos em contado com nossa verdade interior. Já havia vivenciado aquela experiência numa vivência durante uma das aulas da disciplina Mitohermenêuticas da Arte: Ancestralidade e Criação.

Porém, passar pela experiência de amassar a massa primordial, junto aos gestores de Campo Limpo, devolveu-me ao lugar de origem. Aquela experiência trazia a certeza de não poder mais estar tão próxima das Políticas Públicas de Educação. Vi que minha alma, voltava a ter um sopro de vida no campo das Poéticas Públicas, lugar este que não mais poderia ocupar trabalhando num órgão intermediário.

Ao lado das tradicionais políticas públicas, aqui o predomínio do anthropos, isto é, da noção de pessoa, nos direciona às poéticas públicas. Caberia reformular o papel do Estado, de pai autoritário, líder patriarcal, e provedor quase "divino", pelas artimanhas da tecnoburocracia, a elemento democrático de criação, manutenção e conservação de espaços públicos para que as poéticas públicas possam exercitar as alternativas mais adequadas às realidades comunitárias. Cabe ao Estado garantir os espaços públicos e sociais. Nessa dimensão antropolítica, a política da pessoa no mundo se revela em processos de mudanças sem ocupação do poder (obsessão neurótico-compulsiva-político partidária). Enquanto não tivermos uma maior experiência dos mecanismos de participação democrática (ao invés da democracia representativa), estaremos ainda reféns de um Estado tecnoburocrático compromissado com o espírito do capitalismo e distante das demandas populares no seio do cotidiano mais banal das comunidades. A lição que podemos aprender com as comunidades ancestrais é de grande importância na aprendizagem de outros modos possíveis de ser e de mecanismos de prevenção ao aparecimento do próprio

\footnotetext{
${ }^{151}$ Gianotti, 2001, p. 64
} 
Estado. Como advertia Nikolay Berdyaev, as grandes forças que combatem pela pessoa no mundo são a memória, o amor e a criação ${ }^{152}$.

Trabalhava na Divisão de Orientação Técnico-Pedagógica não mais entre aqueles com quem compartilhava pertencimento. Conheci as limitações dos partidarismos e me senti uma estranha sem ninho. Aos poucos, restávamos eu e outras duas parceiras como sobreviventes de um tempo que já não tinha lugar, nas novas Políticas Públicas.

Decidi voltar para a coordenação pedagógica de uma EMEI. Talvez lá fosse uma terra mais próxima das Poéticas, onde minha transgressão pudesse estar tão próxima às crianças, ao ponto de juntas brincarmos em outro "Quintal Mágico". De novo, a força motriz de uma mulher como Therezita Pagani, inspirando o retorno, junto à alquimia oportunizada pela transformação da massa, delicadamente modificada pelos sopros de Sirlene Giannotti e a força acolhedora e generosa do parteiro de almas Marcos Ferreira-Santos:

Neste sentido, mais antropolítico é que uma educação mais consequente sempre tenderá à formação (ou mais precisamente, à autoformação) de pessoas desadaptadas ao status quo, inconformadas, desajustadas e que passarão a desempenhar o papel desestabilizador dentro das organizações (e nas organizações escolares e acadêmicas, sobretudo) pela predisposição às experiências, vivências, imprevisibilidades dos processos, valorização do novo e do trágico, em detrimento das mesmices endêmicas, mesmo que travestidas de normas, regulamentos, decretos-leis e sucessivas mudanças nos modismos educacionais, de gestão e de representação democrática. 0 aparente caos que uma pessoa autoformada produz é o elemento poiético (criador) de um outro cosmos. Serão estes destinados à marginália das contra-correntes que exercitarão com maior acuidade o elemento antropolítico mais importante ao se considerar o caráter complexo das tramas sociais e políticas: a necessidade da criação. A antropolítica vai pari passu com a poética ${ }^{153}$.

Em janeiro de 2014, retornei para o trabalho da coordenação pedagógica numa escola de Educação Infantil. Trata-se da minha experiência profissional atual na rede municipal. Como coordenadora pedagógica eu vivi a experiência de atravessar o risco e agregar o ganho pelo contato com a alteridade. Durante as reuniões de estudo e na execução das rotinas diárias vi a necessidade de oportunizar reflexões, tematizando as práticas realizadas pelos educadores, considerando seus discursos e representações.

\footnotetext{
152 Ferreira-Santos \& Almeida, 2011, p. 10-11

${ }^{153}$ Ferreira-Santos \& Almeida, 2011, p. 10
} 
Vi o quanto vivenciar a troca com o outro pôde possibilitar a ampliação do nosso olhar sobre as crianças e sobre o que realizávamos em nosso trabalho com elas.

O labirinto do cotidiano escolar e seu vibrante ritmo tecem redes de convívio, nas quais histórias de vida se cruzam, estabelecem mútuas relações que se interpenetram numa cultura escolar. As imagens que dela emergem nas práticas e nos discursos dos educadores constituem meu tema de investigação. Constituem "o chamado à aventura".

Formação que para além de aspectos técnicos abraça uma experiência humanizada pelo resgate da memória, nas marcas deixadas no corpo e na alma. Nos mitos que flutuam pelos percursos de quem se reinventa diariamente, ao trabalhar na educação, na pulsante dialética gerada entre imaginação e realidade.

Afinal o que esta autobiografia teria revelado até o momento sobre o imaginário daquela que narra sua própria história, a partir de seus processos formativos?

Provavelmente, o desejo de continuar criando através da experiência cotidiana e o empoderamento que a narrativa de si proporciona à mulher educadora auxiliando na construção contínua de sua pessoa e viabilizando sua potência.

Na experiência atual, voltando à coordenação pedagógica de uma EMEl localizada a menos de um quilômetro de minha casa, estou provavelmente, à procura do "Quintal Mágico", ou do que pelas palavras de Ferreira-Santos sejam as Poéticas Públicas.

Pelas minhas mãos, tenho tido o prazer de reorganizar os espaços. Uma das últimas experiências foi a de reinventar o espaço da brinquedoteca da escola. Reorganizando cantinhos, panelinhas, bonecas, carrinhos e ferramentas, outras histórias estão sendo oportunizadas.

Nossas mãos são a única coisa que, como trabalhadores, temos. Ademais, são também, além do sustento, o nosso amor: carinho e entrega, partilha e cumplicidade, plantio e amizade. (...) Ainda que dentro dos limites organizacionais dos sistemas públicos estatais de ensino, a sugestão que enfatizamos é a substituição da concepção de grade curricular (como jaula epistemológica) para o exercício experimental de uma vivência curricular, valorizandose os itinerários de (auto)formação. Trata-se de substituir a ideia de um currículo (percurso formativo com fragmentação dos saberes) por uma prática transversalizada, por meio da convivência solidária entre saberes re-ligados pela prática experimental, valorizando o questionamento do entorno imediato e também mais amplo, exercício criativo na expressão 
dos problemas nas várias linguagens e busca de soluções. Essas soluções necessitariam ser debatidas e exercitadas no âmbito da comunidade em que a escola está inserida ${ }^{154}$.

O que desejo é viver a experiência. Descobrir o que minhas mãos poderiam criar nesta nova cultura e quais marcas ela estaria esculpindo na minha alma e corpo. Gostaria de aprofundar minhas investigações sobre a corporeidade, tanto na perspectiva da criança quanto na do adulto.

Da fome da alma à sede do corpo, nossa afirmação como pessoa não pode prescindir de seu estatuto sagrado e coletivo ao mesmo tempo, seu drama próprio.

Sobre a experiência numinosa do prósopon, em sua iniciação theanthrópica, poderíamos dizer pelas palavras de Ferreira-Santos:

que no vórtice da experiência numinosa, o ser é levado ao centro do olho do turbilhão, onde mais que sair de si, inicia a viagem para dentro de si. Eis porque o iniciador de cultura é também iniciador theanthrópico: envolve a constituição divina do homem (theos) e a constituição humana do sagrado (anthropos), numa relação recursiva de determinações e aberturas. Daí o drama humano se revestir do drama mítico dos deuses. Isto possui uma função mediadora ambivalente: chama-nos a atenção para o mundo real e concreto, mas também para a possibilidade de torná-lo mais humano. Quanto mais humano, mais sagrado. Sem esta ousadia, diz Berdyaev ${ }^{155}$. ... a revelação da humanidade de Deus carece de sentido: Deus é a maior ideia humana. A ideia do homem é a maior ideia divina. O homem espera dentro de si mesmo o nascimento de Deus. Deus espera dentro de Si mesmo o nascimento do homem. Sobre esta profunda base deve colocar-se a questão da atividade criadora do homem. É um pensamento extremamente audaz o crer que Deus necessita do homem, da resposta do homem, do ato criador do homem. Mas, sem tal audácia a revelação da humanidade de Deus carece de sentido (...) Ele se revela na experiência espiritual do homem, não na especulação teológica: o drama divino penetra o drama humano ${ }^{156}$.

É pelo inacabamento do meu ser e da minha obra que recorro à ajuda dos leitores na continuidade desta obra aberta ao sopro de novas primaveras...

\footnotetext{
${ }^{154}$ Ferreira-Santos \& Almeida, 2011, p. 139.

155 Berdyaev, 1957, p. 197-8.

156 2000, p.69-70
} 


\section{Empoderamento da mulher: considerações finais}

Naquela manhã, despertei com o coração mais agitado, pois em ressonância com ele imagens pulsavam em meu interior, como numa torrente, buscando materializar-se pela palavra.

Estas imagens surgiam como insights daquilo que deveria ou poderia escrever para registrar o instante de minhas considerações finais, na intenção de criar um capítulo final para registrar algo que ainda não teve fim: a vida em seu intenso fluxo.

As imagens surgiram como numa retrospectiva do percurso durante o doutorado. Lembrei-me dos desafios que foram superados para frequentar as disciplinas e do prazer gerado pelos encontros em cada aula. Em particular, das vivências, dos saraus e de ter tido a oportunidade de conhecer outras pessoas, que tanto quanto eu, eram apaixonadas por suas apostas de pesquisa. Dos encontros de orientação com o professor Marcos Ferreira-Santos que revelavam muitas contribuições em termos de indicações bibliográficas, mas principalmente, revelaram tanto sobre eu mesma, pela sensibilidade e generosidade do mestre iniciador e companheiro ao longo de toda a jornada do doutorado.

A narrativa do si mesmo foi um reencontro, como se fosse uma oportunidade de "religação" após ter vivenciado inúmeros processos de ruptura.

Ao escrevê-la pude reconhecer o quanto estas rupturas fazem parte da vida e que narrar tal jornada abriu-me o caminho para contar também a anti-história, pois ela não foi construída apenas pelos momentos de sucesso ou vitórias, ou do empoderamento da mulher, mas também pelos momentos de perda, fracasso, doença, contradição, angústia, medo e solidão.

Não foi constituída apenas pelos lampejos da luz, mas de suas penumbras de sombra.

A narrativa versou sobra a busca de uma escrita autêntica, capaz de integrar a sombra, ao reconhecer que durante a jornada, muitas vezes, alcançamos a bem-aventurança quando deixamos repousar o gládio.

Lembrei-me da lenda de Parsífal e das aproximações com meu próprio caminho, assim como do conto Carne de Língua. Em ambos, vidas vazias foram curadas e preenchidas de sentido.

Ao caminhar durante a narrativa, em busca de um possível castelo do Graal, enquanto cavalgava pelas palavras, sendo levada pelas brumas orvalhadas da memória, fui retirando os vestígios de armadura, que ainda carregava, para então, encontrar a verdadeira face, o Self. Permitindo-me sentir a dor das feridas ao mesmo tempo em que as compartilhava, fui 
desenvolvendo um ato de compaixão, iniciando um processo de cura, buscando regenerar-me na comunhão com meus semelhantes.

Trata-se de um momento de reconhecimento estético libertador. O herói, ou talvez aqui, a dramática heroína despe-se diante do espelho para reconhecer-se da maneira que sempre foi e nas novas curvas e contornos adquiridos ao afirmar-se como uma pessoa.

Durante o percurso esta pessoa assumiu várias formas - menina-mulher, amante, velha-sábia, grande-mãe e Ariadne - que foram expressas pelas marcas do corpo, mas também pelas imagens vivas de cada um de seus momentos: desde sua iniciação.

Se pudéssemos capturar estas imagens como se fossem fotografias, perceberíamos que por estarem sempre em movimento podem parecer algumas vezes, desfocadas, nem sempre tão nítidas.

Nesta tentativa de fotografar-me de dentro para fora e de fora para dentro, reconheci um outro modo de olhar, um olhar atento à escuta, reconhecendo uma "outra estética" que chamei "libertadora", pois nela fui capaz de perceber a beleza do fortuito, da mescla, das manchas da imagem que por estar viva não se permite reconhecer completamente nítida, coerente, altiva e iluminada, mas se constitui pela e na trajetividade, na dinâmica do movimento, que faz transpirar, desgrenhar os cabelos, embaçar a lente, dado o calor de sua pulsão e respiração.

Estas imagens vivas do que somos permitem-nos contemplar a beleza do crepúsculo, do luscofusco que entre razão e emoção, luz e sombra, masculino e feminino, animus e anima, vilã e mocinha, revelam algo novo sobre nós. Quando Ariadne, finalmente, integra-se com o minotauro.

Cito a sensível e assertiva descrição desta trajetividade crepuscular, pelas palavras de FerreiraSantos:

O caminhar, lembrando o poeta espanhol, Antonio Machado, em seu Cantares: "Caminhante, no hay caminos; se hace camino al andar; verso a verso; golpe a golpe..." tem a conotação práxica de realizar no mundo concreto as imagens da alma e as reflexões do espírito. Passo a passo, golpe a golpe. Este caminhar em profundidade possui íntimas ligações com a sensibilidade dramática em sua configuração crepuscular que nosso estilo mitohermenêutico tem condições de pôr em relevo.

O termo latino crepusculum significa crepúsculo ou luz fraca. Deriva, por sua vez, do adjetivo creper (obscuro, duvidoso, incerto) que se desdobra em creperum (escuridão). No entanto, o radical creper em crepusculum é talvez inflexionado por diluculum (o romper do dia). De qualquer forma, denota a ambiência de transição da luz à escuridão, ou vice-versa, 
cuja natureza obscura e duvidosa do lusco-fusco é iluminada por uma luz fraca, daquilo que denomino de lumina profundis, o olhar em profundidade que ilumina, de soslaio, tão somente o necessário sem o ímpeto augusto da ilustração total. ${ }^{157}$

Escrever minha narrativa autobiográfica levou-me a confirmar que a vida se dá pelo movimento e pelo repouso, pela sístole e pela diástole, pela abertura e pelo fechamento. É na captura do instante híbrido que nos percebemos como pessoas em nossas singularidades compartilhadas, autênticas ao assumirmos nossa inautencidade. Foi ao longo desta trajetividade crepuscular, escalando grandes alturas ou imergindo pela descida úmida nas proximidades das "águas profundas", que me identifiquei com este "caminhante" que caminha entre a luz e a sombra, penetrando arquetipicamente em camadas mais profundas, como numa arqueologia em terras primordiais, atualizando nossa ancestralidade na edição mais atualizada do que somos.

Apenas no momento presente, assumindo nossa efêmera condição gerada pela impermanência de todas as coisas, que podemos embarcar em novas naus pelas areias do tempo.

Paradoxalmente, é no instante de repouso que temos a oportunidade de contemplar o movimento. É admitindo o futuro certo da morte que aprendemos a desfrutar o sabor das coisas simples e especiais da vida.

A imagem que agora uso como metáfora é a de ver monges contemplando suas belas mandalas confeccionadas após um longo período, mas que imediatamente após termina-las as sopram, e assim, as mandalas se "des-mancham".

A exemplo destas mandalas somos seres da impermanência. Podemos "desmanchar" no momento mais pleno de nossas vidas quando nossas areias se religam ao seio da terra: nossa grande mãe.

Reconciliando-nos com as rupturas da vida, preparamo-nos para nosso desfecho. E neste momento, religamos o uno ao múltiplo, completamos o ciclo marcado pelo reencontro da calda da uroboros. Religamo-nos às frondosas raízes da árvore de nossa existência, integrando-nos à sua sombra.

Provavelmente, o exercício de construir a presente narrativa autobiográfica, seja também, a materialização da metáfora da busca do Graal, quando em cada nova linha tive a oportunidade de olhar as novas formas que as areias do que sou iam formando, imortalizando-me pelo ato da criação.

\footnotetext{
1572003, p. 155
} 
Se a narrativa de minha vida foi uma mistura de realidade e imaginação, também, e por isso mesmo, foi uma possibilidade de empoderamento do caminho da mulher, naquilo que permitiu reconhecê-la como obra de vida, no seu inacabamento e nas possibilidades do devir.

O filósofo Paul Ricoeur, personalista e hermeneuta, já nos advertia que existe "a constituição mútua do tempo e da narrativa no sentido de que a matéria do tempo só é organizada pela nossa sensibilidade e razão, através de nossa função imaginativa. A aporia do tempo (seu caráter paradoxal) só se deixa revelar se imagino este tempo no fio da narrativa, tratando dele em seu passado, vivenciando-o em nosso presente, ou na expectativa do futuro que se desfia no devir". 158

Retomo a aventura de Parsífal, escrita por Wolfram, já apresentada anteriormente, pelas palavras de Keleman e Campbell. ${ }^{159}$

Lembro que quando li a lenda de Parsifal fui tomada por uma forte emoção. Reconheci-me em vários momentos daquela jornada. Especialmente, durante o período em que estive em licença médica, quando fui levada pelo movimento de meu próprio corpo a parar. Lendo a lenda de Parsífal pude reconhecer imagens de minha narrativa como insights.

Utilizando a contribuição de Willian Sheldon ${ }^{160}$ - apresentada por Keleman - descrevendo a teoria dos tipos constitucionais, tomei contato com os três temperamentos baseados nas três camadas embriológicas do corpo.

Conhecer esta teoria trouxe um novo significado para a narrativa autobiográfica ao agregar a experiência corporal como uma forma própria de narrativa. Sobre estes temperamentos baseados nas três camadas embriológicas do corpo, Keleman descreve:

No tipo endomórfico, metabólico, predominam os hormônios e os tecidos da digestão e da respiração. Esse temperamento orienta-se para o cuidado e para a intimidade. No tipo ectomórfico, predominam os neuro-hormônios e os órgãos da sensação. Esse temperamento está orientado para coletar informações sensoriais. No tipo mesomórfico predominam os hormônios da ação, os grandes músculos e os ossos. Esse temperamento orienta-se para a ação. O endomorfo brota da camada visceral, o mesomorfo, da camada intermediária e o ectomorfo, da membrana externa do embrião. Essas organizações somáticas são herdadas e determinam o modo como as pessoas experienciam a si mesmas e como o mundo faz sentido para elas. Cada uma dessas organizações está ligada a um conjunto diferente de mitos. O mesomorfo está ligado aos mitos do guerreiro, o

\footnotetext{
158 Ricoeur, 1997, p. 126

159 Keleman, 2001, p. 73-81

160 Sheldon (1970) apud Keleman, 2001, p. 31.
} 
endomorfo, aos mitos dos fundadores de comunidades agrícolas e o ectomorfo, aos mitos dos sábios e ascetas. ${ }^{161}$

A experiência da internação, como já relatei anteriormente, foi um momento no qual parei para me dedicar ao meu processo de regeneração e cura.

Como coordenadora pedagógica exerço uma função de gestão que me exigiu por muito tempo uma postura mais racional e objetiva, uma postura "diurna" na qual em muitas situações empunhei simbolicamente "o gládio" ao exercer um cargo com atribuições a serem desenvolvidas. Mas representar um papel não foi suficiente para responder as questões geradas pelas demandas cotidianas. Os impasses trazidos diariamente geravam angústia, pois nem sempre encontrava as respostas para cada uma destas situações, desde a necessidade de planejar encontros de formação que pudessem contribuir para a prática pedagógica dos educadores, motivando-os no processo de qualificação profissional. Ou no atendimento às famílias quando conhecia mais profundamente as histórias de vida das pequenas crianças que já carregavam fardos tão pesados.

Percebi que ao assumir o papel da coordenação pedagógica simbolicamente carregando o gládio das normatizações, legislações e dos regimentos e da lógica do "dever ser"; carreguei também um grande peso por muito tempo. Não era de se surpreender que foi o problema na coluna cervical que me levou à internação.

Também percebi o quanto a leveza de se contar e ouvir histórias, de se confeccionar bonecas e de se permitir brincar junto às crianças e aos adultos, em diferentes situações cotidianas, tornou-se um fazer necessário e significativo para equilibrar o peso da cultura instituída e normatizada com a leveza plasmada da cultura instituinte. Peso este, que em muitos momentos, distanciou-me do vínculo pessoal com o grupo, já que o discurso competente ${ }^{162}$ assim o exigia: afinal neste discurso "o bom profissional é aquele que não se envolve em questões pessoais", acima de tudo busca a eficiência.

Mas a pergunta que não se permitiu calar ao longo do processo, ainda quando se materializava na enxaqueca, na alergia ou na crise de hérnia de disco era: "será mesmo possível para qualquer ser humano, afastar-se de sua humanidade, sob o preço de alienar-se de si mesmo"? Mauricio Tragtenberg a este respeito afirma:

\footnotetext{
161 Keleman, 2001, p. 32

162 Chauí, 1984.
} 
A organização apropria-se de nosso corpo, de tal forma que qualquer ruptura nos aparece como uma auto-ruptura. É aí que a adesão à organização encontra um de seus fundamentos: o corpo, que adere à organização visualizando a possibilidade de uma ruptura reage com alta carga de ansiedade. Controladores e controlados engajados no mesmo processo participam de uma comunidade de destino: a organização da racionalidade. A análise da violência e do sacrifício é inerente à estrutura organizacional. ${ }^{163}$

Mesmo tendo conhecimento do poder devorador da burocracia tecnocrática sobre nossos processos criativos, muitas vezes, reproduzi este discurso competente, confundindo minha auto-imagem na paisagem cinzenta de um fazer inautêntico, distanciado de um fazer criativo. Lembro-me o quanto fiquei indignada quando por pressões da demanda fomos obrigados a fechar espaços alternativos da escola, como a sala de audiovisual e o atelier - que não deixou sequer de ser um projeto - já que mesmo antes de ser viabilizado foi transformado em nova sala de aula. É a pressão institucional e as políticas públicas que priorizam o acesso da criança à escola, deixando a qualificação deste acesso, para segundo plano.

Mas de qual direito estamos tratando? De se frequentar uma escola contraditória que profere discursos vanguardistas, mas continua com práticas de uma estrutura de funcionamento colonial?

Como qualificar o acesso, se na maior cidade de nosso país, admitimos a possibilidade de um único educador, dar conta de mais de trinta e cinco crianças entre quatro e cinco anos na Educação Infantil e ao longo de todo o Ensino Fundamental?

Vivemos a hipócrita, esquizofrênica e sádica realidade, de como educadores, profissionais da educação não sermos ouvidos por nossos governantes. Criam instrumentos de avaliação institucional, mas não prosseguem suas ações de continuidade, que poderiam atender as demandas apontadas.

Não é de se espantar, que numa manhã ao acordar, senti que meu corpo não estava obedecendo aos comandos, pois provavelmente, o corpo já soubesse o preço que teria de pagar ao ser submetido à condição de "ser mais uma peça da engrenagem". É como se o corpo num ato de sobrevivência e transgressão gritasse com suas vozes, negando-se a continuar vivendo uma história inautêntica.

Curiosamente, não nos damos conta, no fluxo cotidiano de nossas ações, desta apropriação que a organização escolar, entre outras organizações burocráticas, faz de nossos corpos e

\footnotetext{
${ }^{163}$ Tragtenberg, 1976, p.15-30
} 
mentes. Na dinâmica da ascensão profissional (devidamente acompanhada de uma certa ilusão de ascensão social), cedemos à lógica de funcionamento da organização e aderimos, geralmente, de maneira acrítica. E, precisamente, a senha dada pelo staff instituído na organização é aquela que, como organismo burocrático, inibe o caráter inovador e criativo da cultura. O staff Ihe diz: "esqueça tudo o que você aprendeu! Na prática a teoria é outra..." O que equivale a dizer, sub-repticiamente: "não subverta a ordem estabelecida das coisas! Não invente, não crie problemas, não altere a rotina!". O que poderíamos também traduzir, hermeneuticamente, por: "Não seja você mesmo!"...164

Todas as vezes que nos calamos quando nosso coração pulsa pelo sonho e não se sente ouvido, vivenciamos a violência, ainda que simbólica. E como diria Sartre: deixamos de ser, nos entregamos à nadificação do ser. Experimentamos o ácido sabor de ser um nada.

Mas para além da sensação de impotência ainda podemos sentir nosso pulso todas as vezes que nos indignamos e nos diferenciamos da paisagem cinzenta de uma vida inautêntica.

Assim, como na lenda de Parsifal e no conto Carne de Língua, o corpo fragilizado do rei e da rainha voltam a se preencher de vida ao se abrirem para a criatividade, para a imaginação, ouvindo a relva crescer para fazê-los lembrar de quem de fato eram.

Ainda pulsamos, quando nos indignamos com as contradições macroestruturais e cotidianas.

Lembrei-me de quando ao ser comunicada por uma supervisora sobre a possibilidade de fecharmos também a sala de leitura, após termos investido na realização do projeto "Vivenciando a Literatura" no qual um de seus pilares era termos um espaço organizado com o acervo literário da escola para permitir o acesso e a circulação dos livros, garantindo maior diversidade de gêneros textuais.

Respondi a esta supervisora que caso esta situação de fechamento da sala de leitura se confirmasse eu faria questão de queimar o Projeto Político Pedagógico da escola em uma reunião pública, se possível num momento de grande visibilidade eleitoral, para dar meu testemunho de indignação face às contradições do sistema público educacional que sabota as próprias propostas por ele exigidas.

Recebi como resposta, um conselho da supervisora que me alertou para a possibilidade de que se eu fizesse tal ato, poderia passar por uma averiguação de capacidade laborativa, demonstrando o quanto meu ato poderia ser caracterizado como insanidade profissional.

${ }^{164}$ Ferreira-Santos, 2003, p.157 
Preferi demonstrar minha indignação diariamente, ao transgredir a lógica de que não se pode fazer um bom atendimento às crianças e à comunidade numa escola pública. Procurei estimular as práticas pedagógicas das educadoras, assim como, muitas vezes, fui encorajada por elas a continuar plantando minhas sementes. Planejando e realizando conjuntamente, procurava experimentar a potência plasmada da alegria de ver as crianças mais felizes com a atmosfera de uma escola mais viva e colorida.

A alegria dos educadores em geral, das professoras e das crianças passou a ser minha principal motivação. Ao me sentir útil após um atendimento familiar, quando ouvia as histórias das crianças contadas por seus familiares, passei a desenvolver o olhar da escuta. Algumas vezes, reconhecia aspectos comuns em nossas histórias, e isto, motivava-me em procurar oferecer uma realidade mais acolhedora para estas crianças.

Escrevendo esta narrativa tornou-se evidente o porquê de minha insistência em me indignar ao manter vivas algumas de minhas utopias. Reconheci que todas as conquistas que alcancei em minha vida foram mediadas pela educação. Foi por meio dela, que transgredi o "previsível roteiro" de uma menina nascida numa periferia de São Paulo.

Pelas oportunidades geradas pela educação, sou o testemunho vivo do quanto não existem determinismos ou "roteiros previsíveis". Toda (o) e qualquer criança ou jovem tem o direito de tentar outros mundos possíveis ao conhecer novos repertórios, ao imaginar outras formas de se relacionar com o mundo.

E ao olhar a criança, suas famílias, as professoras e os funcionários em geral como pessoas, com suas histórias e suas necessidades passei também a me olhar e me reconhecer como "aquela que escuta". Ao organizar cuidadosamente os diferentes espaços da escola com o apoio das educadoras me reconheci muitas vezes realizando a "maternagem". Muitas crianças me procuram em primeiro lugar para contar suas histórias, para pedir ajuda ou entregar o mimo de uma flor. As professoras me procuram para compartilhar suas angústias e intenções. Compartilham seus projetos. Procuro garantir ao máximo, condições para que os projetos se realizem: viabilizando os materiais, apoiando as oficinas de culinária, o empréstimo de livros, as sessões simultâneas de leitura, a reorganização da brinquedoteca, a confecção de brinquedos, as apresentações culturais nas atividades de musicalização e movimento, apoiando na viabilização de talheres e pratos de vidro no refeitório, nas visitações ao teatro, entre os atendimentos diários de crianças, famílias e professores nos encontros de formação.

Mas não são apenas flores, também vivencio as angústias, as resistências e os imprevistos que tornam a rotina cotidiana ainda mais caótica, dada a falta de professores em algumas situações, 
crianças que precisam de apoio especializado, para o qual nem sempre conseguimos encaminhamento, professoras que nem sempre estão abertas ao diálogo ou à revisão de algumas práticas e de alguns conflitos com a comunidade.

Somente pela prática transgressora que se torna possível oferecer outras cores à atmosfera institucional cinzenta, tentando plantar novas sementes, buscando romper a tecnocracia que nos imobiliza e nos sobrecarrega com solicitações inócuas e vazias, que nos esvaziam, ao sermos engolidos pelas demandas diárias.

$\mathrm{Na}$ intensa rítmica do cotidiano, ao atender tantas solicitações, e acumulando a função da docência na faculdade, acabei negligenciando minha saúde, o autocuidado, sendo orgulhosa ao não respeitar meus limites como ser humano. Estava mesmo me maltratando e o meu corpo reclamou mais atenção, compaixão e movimento.

Na lenda de Parsífal, ao tratar do processo de transformação indo do orgulho à compaixão, Keleman descreve um passo a passo: a morte da imagem da cavalaria faz surgir a imagem autêntica, mais profunda de Parsífal, a compaixão. É quando ele se torna capaz de reconhecer o sofrimento do rei e usar sua compaixão para curá-lo. A compaixão depende da capacidade de estarmos presentes em nós mesmos ${ }^{165}$.

Ao reconhecer minha fragilidade admiti a necessidade de abandonar a postura corporal que sobrecarregava o peso de meus ombros. Mas longe de estar no "controle" do processo, era o corpo que estava no controle, dizendo que mais do que um gládio e armadura de guerreiro, estava precisando do colo da grande mãe. Mais do que de formalidade, estava precisando de alegria e espontaneidade, tal como, a encontrada na dança circular da dançarina cigana, pois:

O nosso corpo faz uma imagem de si mesmo no seu cérebro. Isso é chamado de imagem corporal ou imagem somática. A maneira como a expressão emocional do nosso corpo aparece para os outros também é uma imagem somática. A mitologia apresenta imagens, como as do acadêmico, do padre, do criado. Quando vivemos mediante essas imagens descorporificadas ou posturas somáticas vazias - papéis que não são enraizados nas emoções do nosso corpo, falta a elas a força emocional para nos dar sustentação. Essas imagens são inautênticas porque mal corporificadas. C.G. Jung via o mito como parte da matriz biológica. Eu o defino como originário das células dos nossos tecidos, uma imagem não linear governada pelo metabolismo corporal.

A vida do corpo é a fonte dos nossos mitos. É disso que o mito é feito, a história somática. O mito tem a ver com o movimento do nosso corpo universal e pessoal. Mito e corpo. Mito

165 Keleman, 2001, p. 111 
e natureza. A mente cria o mito, não a partir de seus programas racionais, mas em resposta a sugestões do corpo em relação àquilo de que ele necessita. ${ }^{166}$

Se o corpo comunica aquilo de que necessita, no meu caso, as imagens da menina-mulher, da amante, da velha-sábia, da grande-mãe, da cigana dançarina e de Ariadne reconciliada ao minotauro, são complementares nos vários momentos iniciáticos de minha jornada feminina. Jornada cíclica em movimento espiral, feito o giro da saia vermelha da dançarina que cadencia o ritmo de suas palmas aos seus pés.

Das mãos que escrevem, trabalham e acariciam e dos pés que ora caminham e em outras dançam buscando novos caminhos e ritmos.

Para além de se pretender desvelar o mito, o que desejo é ouvi-lo, senti-lo e vivê-lo em toda sua autêntica tensão. Quero reconhecê-lo nas marcas do meu corpo, na transpiração, quando me sinto ofegante, quando sinto minhas entranhas revirarem a ponto de ouvi-las de dentro para fora e de fora para dentro. Neste jogo de espelhos, o mito gira numa rítmica constante das vozes que me habitam.

E assim ouvindo as histórias que me constituem como pessoa procurei manter-me aberta para a escuta das histórias dos meus semelhantes. Manter-me aberta para aprender a ser de outros modos possíveis, sempre que necessário, mas sem perder a minha essência, sem deixar de ouvir minha alma.

De fato, foram inúmeras histórias de colegas educadores que me inspiraram, tanto no meu caminho na rede municipal, na minha retomada acadêmica, como também na minha vida como mulher.

Foi uma dessas amigas educadoras que me presenteou num aniversário, com o livro: Mulheres que Correm com os Lobos: Mitos e Histórias do Arquétipo da Mulher Selvagem ${ }^{167}$.

A partir da leitura deste livro - que nunca mais saiu de minha cabeceira - intensifiquei minha caminhada rumo ao autoconhecimento. Foi ao término deste mesmo ano que decidi mandar meu projeto de doutorado, e outros processos simultâneos tiveram início. Surgiu dessa cumplicidade de amigas leitoras o "Concílo das Lobas". O "Concílio" surgiu como uma convocação sagrada entre amigas queridas, para que se reencontrem. Amigas tecelãs que desenvolveram a maternagem umas com as outras. Em nossos encontros, buscamos desenvolver nosso olhar de escuta, exercendo o cuidado de estar próximas de quem nos faz

\footnotetext{
166 Idem, p.60-61

167 Estés, 1994.
} 
bem. Lemos trechos deste livro, planejamos nossas visitações a parques, teatros, cinemas e exposições para cuidarmos de estar nutrindo nossas almas. Sempre lembramos de momentos especiais que compartilhamos. A palavra "Concílio" parece-nos bastante transgressora, e isto nos agrada, já que por ele, somos convocadas a celebrar o sagrado feminino, recuperando nosso matriarcado. Em nossos encontros zelamos umas das outras, e sabemos, o quanto este sentimento de pertença, já nos transformou em verdadeiras lobas para defendermos umas às outras em diversas situações ao longo da vida. Cuidamos para saber se como amigas, ainda estamos perseguindo nossas sagas, sem desistir de nossos sonhos e de nossas possibilidades de criação. Juntas descobrimos que a nossa felicidade nunca dependeu de aspectos externos a nós, e somos felizes quando nos reencontramos, porque nossos olhares ao se cruzarem sempre reconhecem nosso código selvático: o prazer de estar juntas, que desperta a felicidade que vem de dentro, e parafraseando Clarice Lispector, felicidade que vem de dentro de nossos corações selvagens. As três amigas fundadoras do Concílio passaram por jornadas semelhantes. Somos mulheres que passamos por divórcios, por rupturas e retomadas. E durante esses processos simultâneos pelos quais passamos, nossa vida profissional e acadêmica sempre nos aproximou. Mas nossa afinidade ultrapassa as experiências que construímos enquanto trabalhamos juntas. Nossas narrativas de vida, possuem capítulos comuns, talvez pelo fato de sabermos o que Estés descreveu a seguir:

A princípio, o tempo passado com a Mulher Selvagem é difícil. Recuperar o instinto ferido, eliminar a ingenuidade e, com o tempo, aprender os aspectos mais profundos da psique e da alma, guardar o que tivermos aprendido, não voltar as costas, defender aquilo que representamos... tudo isso exige uma resistência mística e infinita. Quando emergimos de volta do outro mundo depois de uma das nossas incursões por lá, por fora pode parecer que não mudamos, mas por dentro reconquistamos um vasto território feminino e selvagem. Na superfície, ainda somos simpáticas, mas debaixo da pele decididamente não somos mais mansas. ${ }^{168}$

Durante a escrita desta narrativa passei por uma destas incursões. Talvez a mais profunda até aqui. Revivi muitas histórias. Afinal, se recortar apenas o tempo que trabalhei na rede municipal de São Paulo, de vinte e dois anos, compartilhei de muitas outras narrativas. Tanto dos colegas educadores, quanto das crianças e de suas famílias. Se somar a este tempo, todas as outras histórias que compartilhei de meus alunos, estudantes de Pedagogia, além de todas

\footnotetext{
168 1994, p. 560
} 
as outras histórias marcantes de pessoas que passaram pela minha vida, se fosse escrevê-las com certeza, esta narrativa seria escrita em vários volumes.

Eis que surge o mito, como o fio que liga todas as histórias de que não esquecemos e cria uma cumplicidade subterrânea que nos move como protagonistas.

Em um desses processos simultâneos, reconheci a dança como um elo necessário para regenerar as forças do meu corpo após a crise de hérnia de disco. Passei por vários processos terapêuticos importantíssimos: massagens, fisioterapia, osteopatia, acupuntura até retomar a academia e a caminhada. E paralelamente, dei continuidade às leituras e estudos do doutorado, que criaram uma ressonância protetora, que muito me auxiliou na compreensão dos processos somáticos pelos quais passava.

E quando, finalmente venci a dor, voltei a dançar. Voltei a me sentir livre, leve e solta. Foi numa das aulas de $z u m b a^{169}$, que me reencontrei com a dançarina cigana que me habita. Durante esta aula, as músicas misturam ritmos latinos, numa atmosfera envolvente e contagiante. Uma aula na qual participam todas as idades. Homens e mulheres liderados por duas professoras incríveis que amam o que fazem, e que a partir de sua energia somos motivados cada dia a ousar novos movimentos.

Foi numa destas aulas que percebi meu corpo em total sintonia com os outros corpos, que ao seguirem uma coreografia, formavam um corpo integrado maior, como numa simbiose. Saí da aula elaborando aquelas sensações tão prazerosas, e analogamente refletindo sobre suas relações com a dança da vida, naquilo que somos unos e múltiplos ao mesmo tempo. Dançar sozinho é prazeroso, mas em grupo é algo muito maior e melhor. Criamos amizades, trocamos experiências e nos completamos. Tanto quanto em todos os outros espaços da vida. Pensei na escola, concluindo que só é possível encontrar sentido naquilo que fazemos, quando compreendemos o quanto necessitamos uns dos outros em nosso processo contínuo de humanização.

Esta conclusão foi recuperada ao ler o que Ferreira-Santos citando Ricoeur nos diz:

(...) Reafirmo o primado da ética (decisão pessoal) sobre a moral (imposição social) para sair de impasses práticos ainda que seja necessário passar pelo crivo da norma para legitimarse. Nos termos de Ricoeur, a sugestão é do primado de uma "pequena ética" que segundo

\footnotetext{
${ }^{169}$ Zumba é um programa para fitness inspirado principalmente pela dança latina. Foi criado por um bailarino e
} coreógrafo de Miami, Alberto Perez. 
ele chamamos perspectiva ética, a perspectiva da vida boa com e para outros nas instituições justas. ${ }^{170}$

Após a incursão, retornando para a escola, é esta a maior contribuição que estarei levando na bagagem. Feito o peregrino que após sua caminhada, percebe que a conquista está no caminho e não apenas na chegada ao seu destino.

Contribuir para a criação desta "pequena ética" participando para além de um projeto político pedagógico, de um plano de vida compartilhado entre todos os agentes que constituem a escola. Compartilhamos um precioso tempo de nossas vidas, a pretexto de nos encontrarmos no locus escola. Mas, criarmos um ethos de pertença é algo muito mais profundo. Um local, onde seja possível uivar como lobas mostrando nossos dentes, enquanto desenvolvemos a maternagem de cuidar de nossas crianças. Oferecendo, como nos primórdios das abayomis, o melhor de nós às futuras gerações. Entregando o bastão do fio da história aos nossos sucessores. Somente um sentimento de amor selvagem pode permitir o alcance desta bemaventurança de viver uma "vida boa".

Vida boa ou viver bem é para cada um, a nebulosa de ideias e de sonhos de cumprimento com respeito à qual uma vida é considerada, mais ou menos, realizada ou irrealizada. É o plano do tempo perdido e do tempo reencontrado. Talvez o tempo reencontrado pelo educador para realizar seu plano de vida no campo da educação, além de retomar a palavra autêntica, seja o tempo de articular as narrativas de vida daqueles que com ele exprimem a pertença a um projeto maior. Pro-jectum sem a conotação programático-racionalista, mas como jactância existencial ao devir... ${ }^{171}$

Reencontrar o tempo, para que ele não seja perdido nas armadilhas da tecnocracia, ou em meio aos egos inflados do pseudopoder acometidos pela hierarquia ou pelas febres políticopartidárias.

Reencontrar o tempo, para sermos senhores e senhoras de nossa própria criação assumindo os riscos e as gratificações deste ato. Como protagonistas de nosso próprio script.

Retornar à escola, após o período de licença-médica, e deste processo de escrita da narrativa autobiográfica, coroa um ciclo, como poderia ser melhor descrito, parafraseando Keleman ${ }^{172}$, ao tratar dos passos da trama formativa durante a lenda de Parsífal:

\footnotetext{
170 Ricoeur (1997) apud Ferreira-Santos, 2003, p. 168

${ }^{171}$ Ricoeur (1991) apud Ferreira-Santos, 2003, p. 169

172 Keleman, 2001, p.71
} 
Passo Um: O herói é mobilizado por um evento ou uma imagem. Para Parsifal, é a imagem da cavalaria (iniciação à gestão escolar).

Passo Dois: Parsifal começa a usar seu corpo como um cavaleiro, à medida que imagina o que é ser um cavaleiro (coordenador pedagógico). Ele experiencia a forma do cavaleiro e do guerreiro (a armadura do ego inflado gerado pelo cargo). Todas as tentativas, todas as guerras, todas as jornadas têm um único propósito: estabelecer e encarnar o corpo do guerreiro, o guerreiro cavalheiresco, o guerreiro social (início das tensões musculares compressoras da medula). Medula que materializa o próprio caminho da libido ou kundalini. Início das complicações do enrijecimento do corpo, mas sem permitir que a dor seja compartilhada, afinal um guerreiro não pode expor sua vulnerabilidade.

Passo Três: A forma do guerreiro começa a ser inapropriada. Os eventos mostram a Parsifal que ele precisa mudar. Esse estágio da história inclui ser solicitado a deixar o Castelo do Graal. Ele ainda está amarrado pelos códigos alheios. Ele não sabe ainda como receber, ser compassivo como ser o indivíduo, de si mesmo, ser sua atitude. Ao desorganizar a postura do guerreiro, ele é capaz de receber a bondade e compartilhá-la (as constantes dores e apatia obrigaram-me a buscar apoio médico, quando então fui afastada da escola).

Passo Quatro: A disposição de Parsifal para aceitar a compaixão muda a sua forma. À medida que a sua forma muda, surgem novas qualidades. Nessa história, o que emerge é a compaixão e a empatia. Para receber alguém, é preciso abrir um espaço dentro de você e responder a isso. É necessário adaptabilidade e ternura em lugar de dureza. Ser continente à situação do outro, tanto quanto a sua própria, é ser outro tipo de herói. Os cavaleiros chamavam isso de "amour". Nós chamamos de empatia (momento da busca e do recebimento de ajuda, a gratidão gerada pela ajuda recebida de várias pessoas de diferentes modos ao longo de meu tratamento).

Passo Cinco: Essa nova forma corporal - uma forma que agora é compaixão - é um homem que compreende, sente empatia e abraça. Essa forma é dura e, ao mesmo tempo, protetora. Parsifal retorna ao Castelo do Graal e promove sua reconciliação com o rei enfermo (todo o processo de abertura à escuta, rosnando para defender as crianças e os princípios de vida compartilhados; o empoderamento na realização de si, pela experiência do corpar, com a devolução de um corpo amado e restaurado ao voltar a preenchê-lo como um verdadeiro Graal).

Essa descoberta que o Graal esteve o tempo todo dentro de nós, é o que a narrativa autobiográfica foi capaz de realizar: viver a experiência do empoderamento da mulher e também como educadora através da narrativa de si. 
E na polissêmica leitura causada pelo mito também poderíamos dizer que aquele herói cavaleiro empunhava o elmo de um animus, feito Parsífal, que sempre acompanhou como fiel escudeiro sua amada anima, sua bela dançarina. Eis a reconciliação sagrada, feito a de Ariadne com o Minotauro, ao percorrer o labirinto num movimento espiral, repetindo velhos ciclos em novas roupagens, feito a uroboros que regressa à própria cauda...

Ao que se segue como retorno, num novo ciclo, surgem apostas em seguir na minha narrativa, investindo na busca dessa escola mais justa, mais viva e autêntica, seguindo o ritmo pulsante daquela que tudo sabe... seja na forma de dançarina, de cigana, de menina, de mulher, de amante, de velha-sábia, de Demeter, de Perséfone, de Ariadne ou Afrodite...

Seguindo constelações de sinapses numa torrente espiral, girando na galáxia de pensamentos plasmados na carne, surgem novos sentimentos que acordam a alma... talvez não mais faminta, apenas plasmando um novo recomeço...

O mito, para começar, que forma a armadura dos conhecimentos religiosos e que se degrada em lendas, contos e fábulas invoca o funcionamento de uma ordem donde está excluída a morte e, logo que a "desordem" da morte aparece, o mito passa apenas a ser exposição do método seguido... pelos homens para reestabelecer a ordem na medida do possível e limitar os efeitos da morte. Contém, assim, em si, um princípio de defesa e de conservação que comunica ao rito. Com efeito, o ritual, quer seja o da grande festa cíclica Sigui dos dogon ou os funerais e do fim do luto como o ritual dos antigos mexicanos, tem o único papel de domesticar o tempo e a morte e de assegurar no tempo, aos indivíduos e à sociedade, a perenidade e a esperança. ${ }^{173}$

Despeço-me nestas considerações finais, propondo um rito de amizade, gerada pela cumplicidade desta narrativa, entre quem lê e quem escreve, inspirada pelo exemplo do que vivenciamos em nossas últimas aulas, durante os cursos oferecidos pelo mestre Marcos Ferreira-Santos, quando fazíamos um brinde aos nossos novos encontros, como nos jardins de Epicuro. Brindemos a nossa esperança. Então não há um fim, somente o anúncio de novos começos, já que a narrativa como criação poética já é uma maneira de transcender. 0 imperativo criativo que se coloca à existência humana e divina é o fio que nos une ao ancestral e aponta nossas destinações para sairmos do labirinto de nossas mortes temporárias ${ }^{174}$.

Em especial, no tocante ao fio de Ariadne, talvez já seja possível ver seus novos contornos desenhados na rítmica da dança da vida.

\footnotetext{
${ }^{173}$ Durand,1997, p.405

${ }^{174}$ Ferreira-Santos, 2009, p. 14
} 
Seguem imagens, na pulsão de novas danças... Para novos renascimentos... Outras Primaveras.

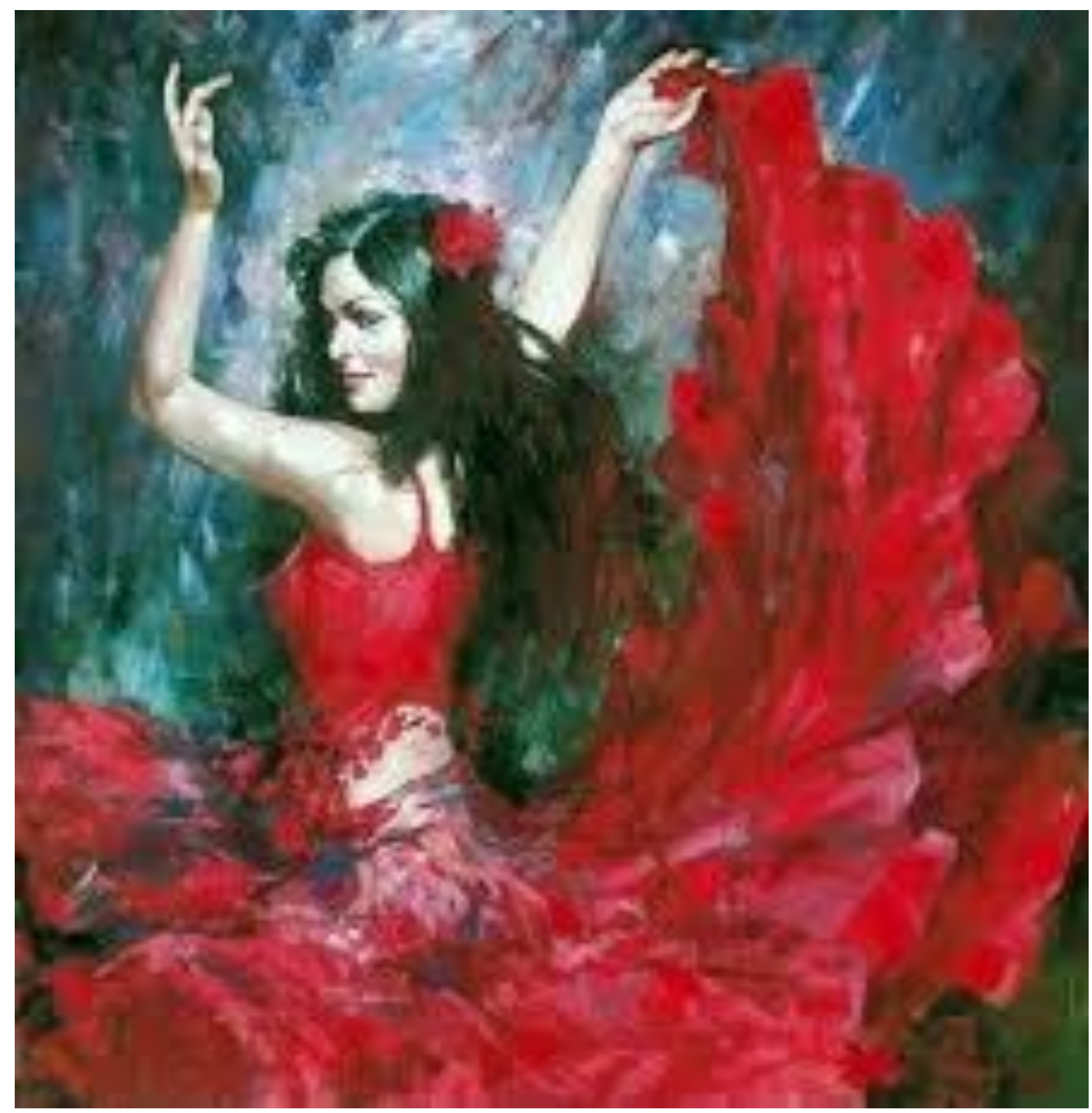

A cigana Salomé

http://filhosdalua.art.br/index.php 


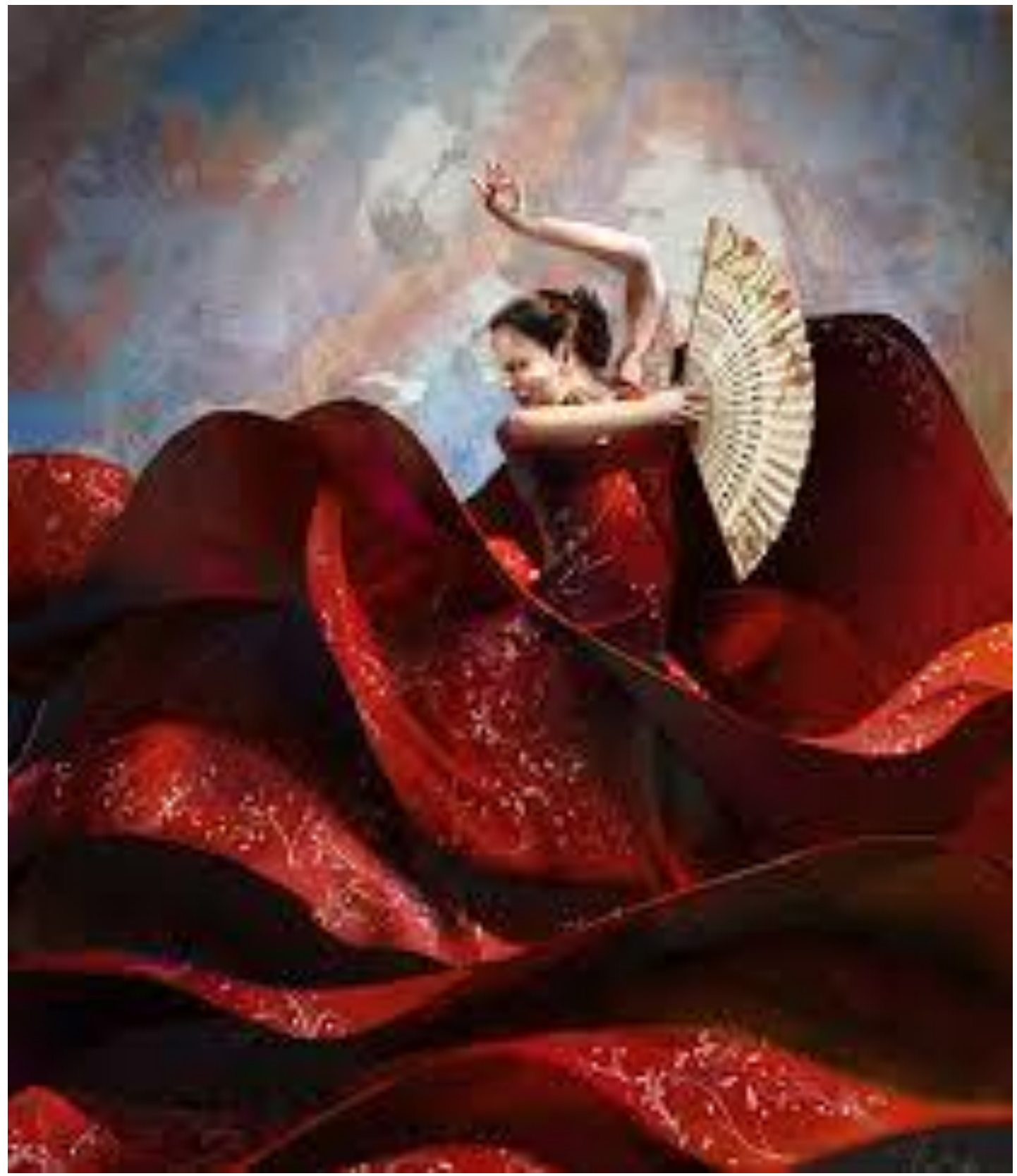


http://fineartamerica.com/featured/mine-uroboros-anna-pocztowska.html

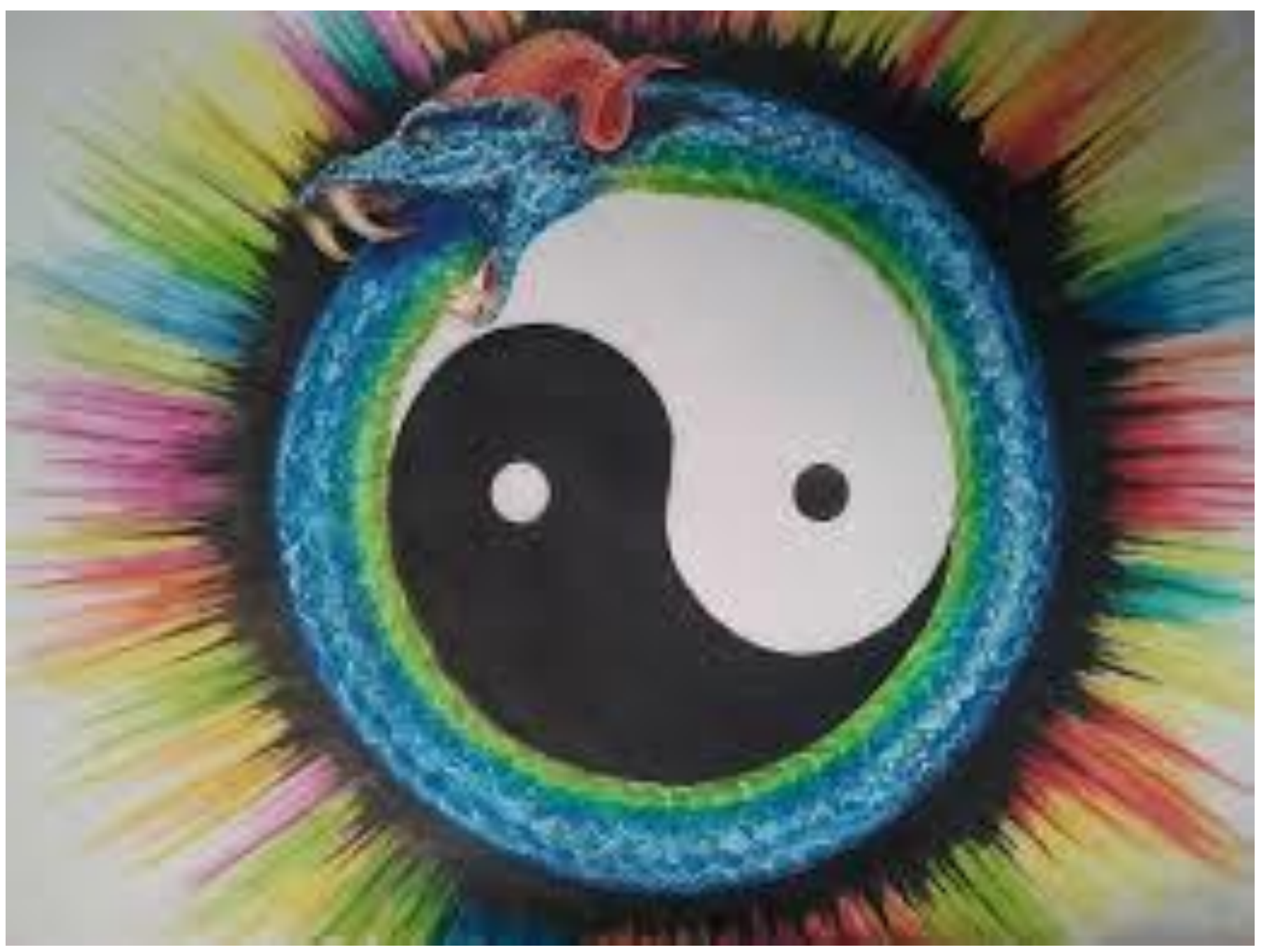




\section{Serpente}

Pitty

Logo mais a manhã já vem

Um presságio

Eu vi também

Arrastou o céu numa conjuração

Corpos ébrios

Em confusão

A sustentação é que a manhã já vem

Logo mais a manhã já vem

O acaso

Empurra quem

Se agarra à borda, preso em negação

Solitário

Na multidão

A sustentação é que a manhã já vem

Logo mais a manhã já vem

Chega dessa pele, é hora de trocar

Por baixo ainda é serpente

E devora a cauda pra recomeçar

Om Namah Shivaya

Om Namah Shivaya

Pelo fogo

Transmutação

Sem afago, lapidando o aprendiz

O que sobra é cicatriz

A sustentação é que a manhã já vem

Logo mais a manhã já vem

Chega dessa pele, é hora de trocar

Por baixo ainda é serpente

E devora a cauda pra continuar

Om Namah Shivaya 
O Abraço do Universo

Frida Kahlo

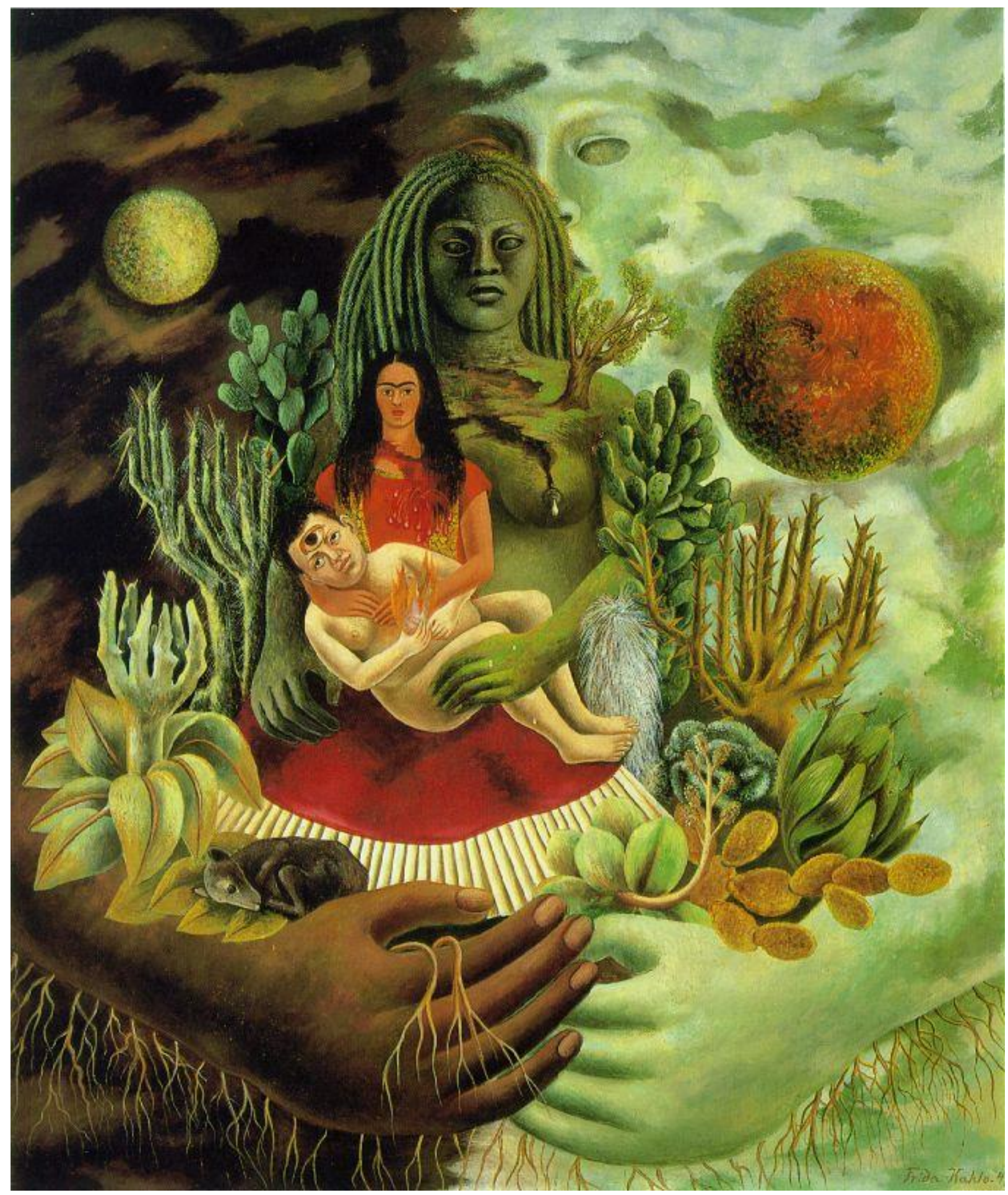




\section{Bibliografia}

ABRAMS, J. e ZWEIG,C. Ao Encontro da Sombra. São Paulo, Cultrix, 1991.

ALBERNAZ, Maria Beatriz. A Poética na escola: uma tese de ficção. Rio de Janeiro: FGV, dissertação de mestrado, 1987.

ALMEIDA, Vera Lúcia Paes de. Corpo Poético: o movimento expressivo em C. G. Jung e R. Laban. São Paulo, Paulus, 2009

ANGELO, Luciana Ferreira. Educação de corporeidade e psicologia do esporte: estudo de caso em um grupo esportivo. São Paulo: FEUSP, dissertação de mestrado, 2002.

APPLE, M. Ideologia e Currículo, São Paulo, Brasiliense, 1982.

AUGRAS, M. O Imaginário e o Cotidiano. In Revista Ciência \& Trópico. Recife: Fundação Joaquim Nabuco e Massangana, vol. 10, n.1, 1982.

AVENS, R. Imaginação é Realidade. Petropólis, Vozes, 1993.

BACHELARD, G. O Ar e os Sonhos. São Paulo, Martins Fontes, 1990.

BACHELARD, G. O Novo Espírito Científico. Rio de Janeiro, Tempo Brasileiro, 1968.

BACHELARD, G. A Psicanálise do Fogo. São Paulo, Martins Fontes, 1994.

BACHELARD, G. A Poética do Devaneio. São Paulo, Martins Fontes, 1988.

BACHELARD, G. A Chama de uma Vela. Rio de Janeiro, Bertrand Brasil, 1989.

BADIA, D. Imaginário e Ação Cultural: as contribuições de Gilbert Durand e da Escola de Grenoble. Dissertação de Mestrado. São Paulo, ECA/USP, 1993.

BADIA, D. Estruturas do Imaginário e Universos Míticos. Revista Educação Pública, Cuiabá, vol. 3, n. 4, 1984.

BADIA, D. Pessoa, Grupo e Comunidade: O Personalismo Ontológico de N. Berdiaev, suas ampliações na antropologia hermenêutica, São Paulo, Plêiade, 2002.

BERDYAEV, N. Autobiografia Espiritual. Barcelona, Luis Miracle, 1957.

BERKENBROCK-ROSITO, Margaréte May. Colcha de Retalhos: história de vida e imaginário na formação. Educação. Santa Maria, v. 34, n. 3, p. 487-500, set./dez., 2009. Disponível em: $<$ http://www.ufsm.br/revistaeducacao>

BOLEN, J. As Deusas e a Mulher: Nova Psicologia das Mulheres, São Paulo, Paulus, 1990.

BOSI, E. Memória e Sociedade: Lembranças dos Velhos. São Paulo, Companhia das Letras, 1994. BRANDÂO, J. Mitologia Grega. Petrópolis, Vozes, 1997.

BRENMAN, I. As Narrativas Preferidas de um Contador de Histórias, São Paulo, DCL, 2007

BRAVERMAN, H. Trabalho e Capital Monopolista: a degradação do trabalho no século XX. Rio de Janeiro, Zahar, 1981.

BUITONI, D. S. DE Volta ao Quintal Mágico: a Educação Infantil na Te-arte. São Paulo, Ágora, 2006.

CAMPBELL, J. O poder do Mito, São Paulo, Palas Athena, 1990.

CAMPBELL, J. As Máscaras de Deus. São Paulo, Palas Athena, 1992. 
CAMPBELL, J. Mito e Transformação. São Paulo, Ágora, 2008.

CAMPBELL, J. A Jornada do Herói: Joseph Campbell Vida e Obra. São Paulo, Ágora, 2003.

CARVALHO, Sibéria Regina. O ensino-aprendizagem da autobiografia: uma possibilidade para o desenvolvimento da linguagem escrita. São Paulo: PUC, tese de doutorado, 2011.

CASTORIADIS, C. A Instituição Imaginária da Sociedade. Rio de Janeiro, Paz e Terra, 1982.

CHAUÍ. M. Cultura e Democracia: o discurso competente e outras falas. São Paulo, Moderna, 1984.

CHAVES, I. Vestida de Azula e Branco como manda a Tradição: Um Estudo Sócio-Antropológico de uma Escola Normal na cidade do Rio de Janeiro. Tese de Doutorado apresentada à Faculdade de Educação da Universidade de São Paulo, 1997.

CHEVALIER, J. e GHEERBRANT, A. Dicionário de Símbolos, 13 ed. Rio de Janeiro, José Olympio, 1999.

CLAIRE, D. Carl Jung: Curador Ferido de Almas. São Paulo, Alaúde Editorial, 2012.

COLONNA, Vincent. Autofictions \& autres mythomanies littéraires. Auch: Tristram, 2004.

CUNHA, L. Educação e Desenvolvimento Social no Brasil. Rio de Janeiro, Francisco Alves, 1980.

DAY, P. Tarô. São Paulo, Callis, 1997.

DOUBROVSKY, Serge. Fils. Paris: Galilée, 1977

DURAND, G. A Imaginação Simbólica. São Paulo, Cultrix/EDUSP, 1988.

DURAND, G. As Estruturas Antropológicas do Imaginário: Introdução à Arqueologia Geral. São Paulo, Martins Fontes, 1997.

DURAND, G. Mito e Sociedade. A Mitanálise e a Sociologia das Profundezas. Lisboa, A Regra do Jogo, 1983.

DURAND, G. Mito, Símbolo e Mitodologia. Lisboa, Presença, 1982.

DURAND, G. O Imaginário: Ensaio acerca das ciências e da filosofia da imagem. Rio de Janeiro, DIFEL, 1998.

DURAND, Y. A Formulação Experimental do Imaginário e seus Modelos. In Revista da Faculdade de Educação. São Paulo, FEUSP, vol. 13, n2, 1987

ENRIQUEZ, E. A Organização em Análise, Petrópolis, Vozes, 1997.

ESTÈS, C. P. A Ciranda das Mulheres Sábias: ser jovem enquanto velha, velha enquanto jovem. Rio de Janeiro, Rocco, 2007.

ESTÈS, C. P. Mulheres que Correm com os Lobos: mitos e histórias do arquétipo da mulher selvagem. Rio de Janeiro, Rocco, 1994.

ESTÈS, C. P. Libertem a Mulher Forte: O Amor da Mãe Abençoada pela Alma Selvagem. Rio de Janeiro, Rocco, 2012.

FERREIRA-SANTOS, M. Crepusculário: Conferências sobre Mitohermenêutica e Educação em Euskadi. São Paulo, Zouk, 2ạ. Ed., 2005.

FERREIRA-SANTOS, M. Práticas Crepusculares: Mytho, Ciência e Educação no Instituto Butantan - Um Estudo de Caso em Antropologia Filosófica. São Paulo, FEUSP, Tese de Doutoramento, 1998. 
FERREIRA-SANTOS, M. Narrativa de vida (mito pessoal), ética e a potência da palavra. In: O crepúsculo do mito: mitohermenêutica \& antropologia da educação em Euskal Herria e Ameríndia. São Paulo: FE-USP, tese de Livre-Docência, p.155-175, 2003.

FERREIRA-SANTOS, M. Matrices de la persona afro-ameríndia: escritura como obra de vida. In: FLOREZ, C.M. (Org.). Urdimbres. Cali (Colombia): Editorial Buenaventuriana, p. 219-248, 2010.

FERREIRA-SANTOS, M.\& ALMEIDA, R. Aproximações ao Imaginário: Bússola de Investigação Poética, São Paulo, Képos, 2012.

FERREIRA-SANTOS, M.\& ALMEIDA, R. Antropolíticas da Educação. São Paulo, Képos, 2011.

FÉTIZON, B. Sombra e Luz: o tempo habitado. São Paulo, Zouk, 2002.

FONSECA, E. M. Trilhando pelo Labirinto: Uma Incursão Antropológica à Latência de uma Escola Municipal. São Paulo: FEUSP, Dissertação de Mestrado, 2002.

FOUCAULT, M. Vigiar e Punir: História da Violência nas Prisões. Petrópolis, Vozes, 1996.

GALLE, H.; OLMOS, A. C.; KANZEPOLSKY, A; IZARRA, L. Z. Em primeira pessoa: abordagens de uma teoria da autobiografia. São Paulo: FAPESP, 2009.

GOFFMAN, E. A Representação do Eu na Vida Cotidiana. Petropólis, Vozes, 1996.

GOFFMAN, E. Estigma:Notas sobre a Manipulação da Identidade Deteriorada, Rio de Janeiro, Guanabara, 1988.

GOMES, I. A Escola como Espaço de Prazer, São Paulo, Summus, 2000.

GINZBURG, J. O impacto da violência e constituição do sujeito: um problema da teoria da autobiografia. In: GALLE, H.; OLMOS, A. C.; KANZEPOLSKY, A; IZARRA, L. Z. Em primeira pessoa: abordagens de uma teoria da autobiografia. São Paulo: FAPESP, 2009.

GUSDORF, Georges. Condiciones y límites de la autobiografía. Anthropos: Boletín de información y documentación, no Extra 29 - La autobiografía y sus problemas teóricos. Estudios e investigación documental, pp. 9-18, 1991.

HALL, S. A Identidade Cultural na Pós-Modernidade. Rio de Janeiro, DP\&A, 2005.

HAMPATÉ-BÂ, Amandou. A tradição viva. In: Ki-Zerbo, J. (Ed.). História geral da África - vol. I: Metodologia e pré-história da África. Brasília: UNESCO, 2a. ed. rev., pp.167-212, 2010.

HESIODO, Os Trabalhos e os Dias, São Paulo, Iluminuras, 1990.

HILMANN, J. Encarando os Deuses. São Paulo, Pensamento/ Cultrix, 1992.

LEJEUNE, Philippe. Definir autobiografía. In MOURÃO, Paula (org). Autobiografia.

Autorepresenntação. Lisboa: Edições Colibri, 2003

LEJEUNE, Philippe. O pacto autobiográfico: de Rosseau à Internet. Belo Horizonte: UFMG, 2008.

JOSSO, M. C. Experiências de vida e formação. Lisboa: Educa, 2002.

JOSSO, M. C. As Histórias de Vida como territórios simbólicos nos quais se exploram e se descobrem formas e sentidos múltiplos de uma existencialidade evolutiva singular-plural. In: PASSEGGI, M. da C. (Org.). Tendências da pesquisa (auto)biográfica. Natal: EDUFRN; São Paulo: Editora Paulus, 2008.

JUNG, C.G. O Eu e o Inconsciente. Petrópolis, Vozes, 1988.

JUNG, C.G. A Energia Psíquica. Petrópolis, Vozes, 1999. 
JUNG, C. G. Símbolos de Transformação. Petrópolis, Vozes, 1989.

KAËS, R. A Instituição e as Instituições: Estudos Psicanalíticos. São Paulo, Casa do Psicólogo, 1991.

KAËS, R. Fantasma e Formação. Paris, Pont Royal, 1964.

KAËS, R. O Grupo e o Sujeito do Grupo. São Paulo, Casa do Psicólogo, 1997.

KELEMAN, S. Mito e Corpo: uma conversa com Joseph Campbell. São Paulo, Summus, 2001.

KHUN, T. A Estrutura das Revoluções Científicas. São Paulo, Perspectiva, 1982.

LAPLANTINE, F. Aprender Antropologia. São Paulo, Brasiliense, 1988.

LARROSA Bondía, Jorge. "Notas sobre a Experiência e o Saber de Experiência" publicado na Revista Brasileira de Educação, 2002.

LARROSA, Jorge. Tremores: Escritos sobre experiência. Belo Horizonte: Autêntica Editora, Coleção Educação: Experiência e Sentido, 2015.

LIMA, Sérgio C. F. O Corpo Significa. São Paulo: EDART, 1976.

MACHADO, R. Acordais: Fundamentos Teórico-Poéticos da Arte de Contar Histórias. São Paulo, DCL, 2004.

MACHADO, R. O Violino Cigano e outros Contos de Mulheres Sábias. São Paulo, Companhia das Letras, 2004.

MAFFESOLI, M. A Lógica da Dominação. Rio de Janeiro, 1978.

MAFFESOLI, M. A Conquista do Presente. Rio de Janeiro, Rocco, 1984.

MAFFESOLI, M. A Dinâmica da Violência. São Paulo. Vértice, 1987.

MAFFESOLI, M. No Fundo das Aparências. Petrópolis, Vozes, 1996.

MAFFESOLI, M. O Tempo das Tribos: O Declínio do Individualismo nas Sociedades de Massa. Rio de Janeiro, Forense Universitária, 1998.

MARCUSE. H. Ideologia da Sociedade Industrial. Rio de Janeiro, Zahar, 1967.

MELLONI, R. Temática da Antropologia Filosófica e da Antropologia Cultural. São Paulo, Plêiade, 1998.

MERLEAU-PONTY, M. Fenomenologia da Percepção. Rio de Janeiro, Freitas Bastos, 1971.

MERLEAU-PONTY, M. O Homem e a Comunicação: A Prosa do Mundo. Rio de Janeiro, Bloch, 1974.

MERLEAU-PONTY, M.O Olho e o Espírito. Os Pensadores. São Paulo, Abril Cultural, 1975.

MERLEAU-PONTY, M. O Visível e o Invisível. São Paulo, Perspectiva, 1992.

MONDOLFO, R. Problemas de Cultura e Educação. São Paulo, Mestre Jou, 1967.

MORIN, E. A Cabeça Bem-feita: repensar a reforma, reformar o pensamento. Rio de Janeiro, Bertrand Brasil, 2002.

MORIN, E. Ciência com Consciência. Portugal, Europa-América, 1982.

MORIN, E. O Mètodo I: A Natureza da Natureza. Portugal, Europa-América, 1977.

MORIN, E. O Método II: A Vida da Vida. Portugal, Europa-América, 1980. 
MORIN, E. O Mètodo IV: As Ideias. Porto Alegre, Sulina, 1998.

MORIN, E. O Paradigma Perdido: A Natureza Humana. Rio de Janeiro, Zahar, 1975.

NICHOLS, S. Jung e o Tarô: Uma Jornada Arquetípica, São Paulo, Cultrix, 1997.

NÓVOA, A. A formação tem de passar por aqui: as histórias de vida no projeto PROSALUS. In: NÓVOA, A.; FINGER, M. (Org.). O método (auto)biográfico e a formação. Lisboa: MS/DRHS/CFAP, 1988.

NÓVOA, A. (Coord.). Os professores e sua formação. Lisboa: Dom Quixote, 1995.

OSTROWER, F. Criatividade e Processos de Criação, Rio de Janeiro, Vozes, 1996.

PAULA CARVALHO, J, C. Imaginário e Cultura Escolar: Um Estudo Culturanalítico de Grupos de Alunos em Etno-Escolas (Colégio lavne e Liceu Paster/ São Paulo) e numa Escola Rurbana (EEPSG João Pedro Ferraz/ Ibirá). In Revista Educação Pública, Cuiabá, vol. 3, n.4, 1994.

PAULA CARVALHO, J, C. A Culturanálise de Grupos: Posições Teóricas e Heurísticas em Educação, Ensaio de Titulação, FEUSP, 1991.

PAULA CARVALHO, J, C. A Dimensão do Imaginário na Problemática Organizacional da Administração da Educação. In Revista da Faculdade de Educação. São Paulo, FEUSP, vol, 11, 1985.

PAULA CARVALHO, J, C. Antropologia das Organizações e Educação: Um Ensaio Holonômico. Rio de Janeiro, Imago, 1990.

PAULA CARVALHO, J, C. Energia, Símbolo e Magia: uma contribuição a uma antropologia do imaginário. Tese de Doutoramento apresentada à Faculdade de Filosofia, Letras e Ciências Humanas da Universidade de São Paulo, 1985.

PAULA CARVALHO, J, C. Imaginário e o Pensamento Organizacional na Obra de Edgar Morin: seus fundamentos antropológicos. In Revista da Faculdade de Educação. São Paulo, FEUSP, vol. 13, nำ1, 1987.

PAULA CARVALHO, J, C. Imaginário e Mitodologia: Hermenêutica dos Símbolos e Estórias de Vida. Londrina, Ed. UEL, 1998a.

PAULA CARVALHO, J, C. Rumo a uma Antropologia da Educação: Prolegômenos (ii). In Revista da Faculdade de Educação. São Paulo, FEUSP, vol. 10, n. 2, 1984.

PAULA CARVALHO, J, C.[et al.] Imaginário e Ideário Pedagógico: Um Estudo Mitocrítico e Mitanalítico do Projeto de Formação do Pedagogo na FEUSP. São Paulo, Plêiade, 1998b.

PAULA CARVALHO, J, C. Sobre a Gestão Escolar do Imaginário. In Revista Forum Educacional, Rio de Janeiro, vol. 13/2, Fundação Getúlio Vargas, 1989.

PEARSON, C. O Despertar do Herói Interior: A Presença dos Doze Arquétipos nos Processos de Autodescoberta e de Transformação do Mundo. São Paulo. Pensamento, 1991.

PETRAGLIA, I. Edgar Morin: Educação e a Complexidade do Ser e do Saber. Petrópolis, Vozes, 1999.

PIRES, V.F. Lilith e Eva: Imagens Arquetípicas da Mulher na Atualidade. São Paulo, Summus, 2008.

PORTO, M. R. S. e TEIXEIRA, M.S. (orgs.) Imagens da Cultura: um outro olhar. São Paulo, Plêiade, 1999. 
PORTO, M. R. S. e TEIXEIRA, M.S. (orgs.)Tessituras do Imaginário: Cultura \& Educação, Cuiabá, Edunic/ CICE/ FEUSP, 2000.

PORTO, M. R. S. Escola Rural: Cultura e Imaginário. Tese de Doutorado. São Paulo. FEUSP, 1994.

PORTO, M. R. S. [et. al.] Imaginário e Ideário Pedagógico no Projeto de Formação do Educador, FEUSP, 2002.

RICOEUR, P. O Si-Mesmo como um Outro. Campinas, SP, Papirus, 1991.

RICOEUR, P. Tempo e Narrativa, Campinas, SP, Papirus, 1994.

RICOEUR, P. Interpretação e Ideologias. Rio de Janeiro, Francisco Alves, 1988.

RUBIRA, Fabiana. Dançando com o minotauro nas noites: narração de estórias e formação humana. São Paulo: FEUSP, tese de doutoramento, 2015.

ROCHA, E. O que é Etnocentrismo? Brasiliense, 1994.

SÃO PAULO (SP), Secretaria Municipal de Educação. Diretoria de Orientação Técnica. Orientações Curriculares: Expectativas de Aprendizagens e Orientações Didáticas para a Educação Infantil, Secretaria Municipal de Educação, São Paulo, SME, DOT, 2007.

SAIANI, C. Jung, uma Análise da relação Professor/Aluno. São Paulo, Escrituras Editora, 2000.

STEIN, M. O Mapa da Alma: uma introdução. São Paulo, Cultrix, 2006.

TEIXEIRA, M, C. S. Antropologia, Cotidiano e Educação. Rio de Janeiro, Imago, 1990.

TEIXEIRA, M. C. S. Discurso Pedagógico, Mito e Ideologia: o Imafinário de Paulo Freire e de Anísio Teixeira. Rio de Janeiro, Quartet, 2000.

TEIXEIRA, M. C. S. Imaginário e Educação: As Mediações Simbólicas no Universo das Organizações Educativas. In Revista de Educação Pública, Cuiabá, vol. 3, n.4, 1994.

TEIXEIRA, M. C. S. e Porto, M. R. S. Perspectivas Paradigmáticas em Educação. In Revista da Faculdade de Educação, São Paulo, FEUSP, 1994.

TEIXEIRA, M.C.S.\& ARAÚJO, A.F. Gilbert Durand: Imaginário e Educação. Niterói, Intertexto, 2011.

VERNANT, J. P. As Origens do Pensamento Grego, São Paulo, DIFEL, 1984.

VILLAS-BOAS, M. Olimpo: A Saga dos Deuses. São Paulo, Siciliano, 1995.

WILLMS, E.E. Escrevivendo: Uma Fenomenologia Rosiana do Brincar. Tese de Doutorado, SP, FEUSP, 2013. 


\section{http://www.odespertardaautocura.com.br/sagrado-feminino/as-deusas-e-os-seus-arquetipos/}

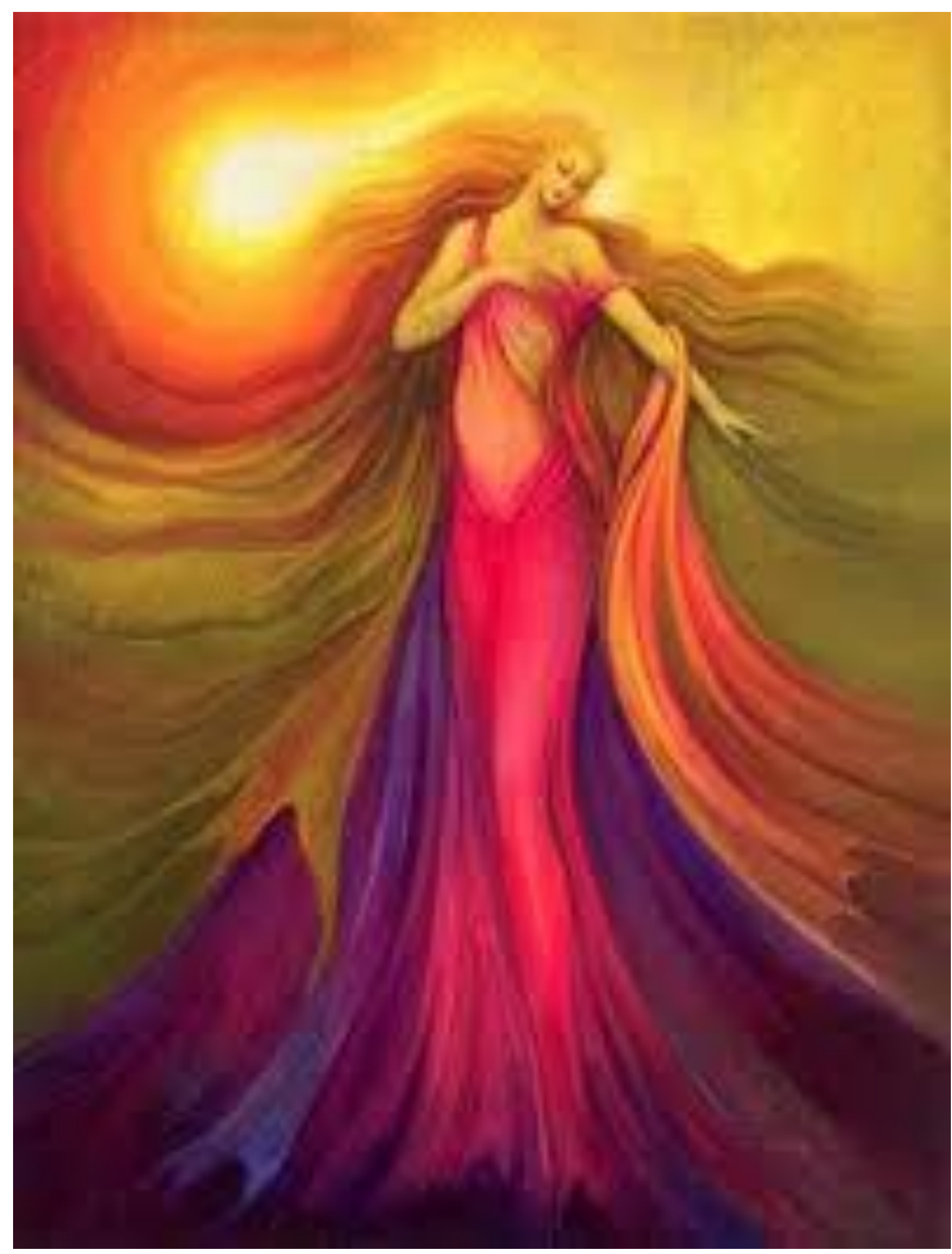

